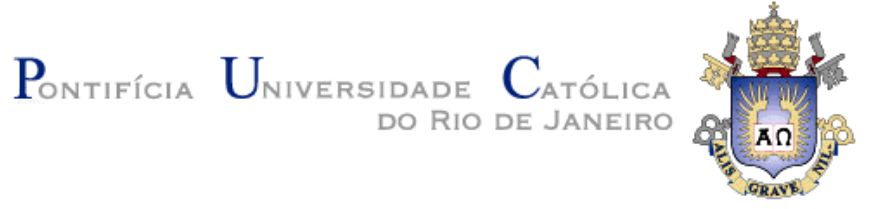

Flávia Rodrigues de Castro

Refúgio e Injustiça Epistêmica:

Uma Análise a partir do Brasil

Tese de Doutorado

Tese apresentada como requisito parcial para obtenção do grau de Doutor pelo Programa de Pós-Graduação em Relações Internacionais do Instituto de Relações Internacionais da Puc-Rio.

Orientadora: Profa. Carolina Moulin Aguiar

Rio de Janeiro

Março de 2020 


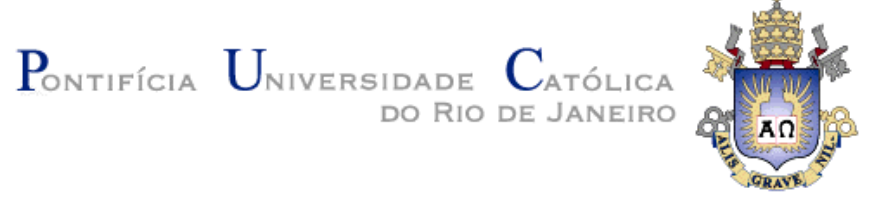

Flávia Rodrigues de Castro

\section{Refúgio e Injustiça Epistêmica: Uma Análise a partir do Brasil}

Tese apresentada como requisito parcial para obtenção do grau de Doutor pelo Programa de PósGraduação em Relações Internacionais do Instituto de Relações Internacionais da Puc-Rio. Aprovada pela Comissão Examinadora abaixo.

Profa. Carolina Moulin Aguiar

Orientadora Instituto de Relações Internacionais - PUC-Rio UFMG

Prof. Roberto Vilchez Yamato Instituto de Relações Internacionais - PUC-Rio

Profa. Liana de Andrade Biar Departamento de Letras - PUC-Rio

Profa. Denise Mercedes Salles Unilasalle e UCP

Profa. Julia Bertino Moreira UFABC

Rio de Janeiro, 06 de Março de 2020 
Todos os direitos reservados. É proibida a reprodução total ou parcial do trabalho sem autorização da universidade, da autora e da orientadora.

\section{Flávia Rodrigues de Castro}

Graduou-se em Relações Internacionais na Universidade Federal Fluminense (UFF) em 2014. É mestre em Relações Internacionais pelo Instituto de Estudos Estratégicos (INEST/UFF). É doutora em Relações Internacionais pela PUC-Rio. Pesquisa migrações, refúgio e práticas de fronteira.

Ficha Catalográfica

Castro, Flávia Rodrigues de

Refúgio e injustiça epistêmica : uma análise a partir do Brasil / Flávia Rodrigues de Castro ; orientadora: Carolina Moulin Aguiar. -2020.

251 f. : il. color. ; $30 \mathrm{~cm}$

Tese (doutorado)-Pontifícia Universidade Católica do Rio de Janeiro, Instituto de Relações Internacionais, 2020.

Inclui bibliografia

1. Relações Internacionais - Teses. 2. Injustiça epistêmica. 3. Refúgio. 4. Elegibilidade. 5. Representação. 6. Brasil. I. Moulin, Carolina. II. Pontifícia Universidade Católica do Rio de Janeiro. Instituto de Relações Internacionais. III. Título. 


\section{Agradecimentos}

Esta tese é o resultado de uma rede de apoiadores - emocionais, financeiros, intelectuais - e os nomes aqui citados são apenas alguns dentre todos aqueles que deixaram muito de si e que ajudaram a formar quem sou e, portanto, o que escrevo. Aproveito para iniciar os agradecimentos considerando todo o apoio financeiro e institucional que obtive no Instituto de Relações Internacionais (IRI) da PUCRio. Agradeço também ao apoio financeiro que recebi durante minhas atividades de pesquisa como bolsista do programa Doutorado Nota 10 - FAPERJ, enfatizando que esta tese foi possível graças ao auxílio fornecido pela fundação.

Há uma famosa frase, atribuída a Gandhi, que diz: God comes to the hungry in the form of food. Se isso é verdade, minha orientadora, Carolina Moulin, veio para minha vida exatamente como eu precisava neste processo de doutoramento. Se eu fui um pouco menos outsider, devo isso inteiramente a ela. Obrigada, Carol, por me considerar, no sentido dado por Marielle Macé - por "olhar atentamente, ser delicada, prestar atenção, levar em conta, tratar com cuidado antes de agir e para agir”. Obrigada, Carol, por 'fazer caso' de mim, germinando, assim, o nascimento desse trabalho.

Seria impossível agradecer nominalmente a todos aqueles que atravessaram brilhantemente este percurso, contribuindo para ampliar minha visão sobre o campo da mobilidade. Aos entrevistados, que me deram muito do seu tempo e do seu ânimo, eu agradeço imensamente. Embora possam não concordar com o que produzi a partir de nossas conversas, busquei tratar com respeito e cuidado tudo aquilo que foi compartilhado comigo - mesmo nos momentos de maior discordância. Meu agradecimento especial ao Charly Kongo por ter me ajudado a estabelecer contatos, a promover encontros em aeroportos e a pensar em alguns pseudônimos adequados.

Meu agradecimento especial a tantos pesquisadores e professores que marcaram a jornada até aqui, contribuindo de formas diferentes para a pesquisa. 
Agradeço ao Bruno Magalhães pelos lampejos de vida e por podermos aprender juntos sobre a potência da fuga e da mobilidade na criação de outros mundos. Agradeço ao Roberto Yamato por ter me acompanhado na trajetória, se fazendo presente e me convocando a participar dos debates e aulas que tanto me inspiraram. Obrigada, Beto, pelas práticas de inclusão. Agradeço a Anna Leander pelos ensinamentos sobre etnografia, pelo encorajamento que me deu nas etapas iniciais do projeto e pela injeção de ânimo na reta final. Suas palavras foram ouvidas, certamente. Agradeço a Denise Mercedes Salles por ser mestra em me chamar para seus projetos, por conversas animadas sobre mobilidade e literatura e pela criação incansável de espaços de trabalho e atuação conjuntos. Agradeço ao Fabrício Souza pela ponte que fez entre vários encontros e, claro, por ter me ensinado que, às vezes, é preciso escrever com raiva mesmo.

Agradeço aos membros da banca por terem aceitado o convite e sou grata, desde já, pelas contribuições ao trabalho. Àqueles que ainda não foram citados aqui, meus agradecimentos sinceros. Agradeço à Julia Bertino por sua presença atenta na qualificação do projeto da tese, pela leitura cuidadosa e pelos questionamentos produtivos. Agradeço à Liana Biar por ter compartilhado comigo o aprendizado da pesquisa com corpus e a exposição dos resultados parciais do trabalho em aula conjunta. Agradeço à Ariane Paiva pela parceria em tantas atividades da Cátedra SVM e ao Charles Gomes pelo trabalho com refugiados e solicitantes mesmo em tempos sombrios.

Felizmente, minha vida é marcada por grandes mulheres que inspiram e acolhem - sem elas, esse doutorado teria sido difícil de sustentar. No trabalho com migrantes e refugiados, no Brasil e no mundo, Natália Cintra, Helena Chermont e Katherine Jensen me fizeram sentir o impacto de seu engajamento, ativismo e produção intelectual. Obrigada por terem compartilhado comigo tantas ideias, por terem me amparado sempre que precisei e pelo lar longe de casa que, curiosamente, todas me deram, em um momento ou em outro. No IRI, minhas companheiras de doutoramento, Verônica Azzi e Mariana Caldas, forjaram as brechas para o afastamento da competição em direção ao refúgio da parceria. Em bodas de prata de amizade, meu agradecimento especial a Tatiane Proba por ter se feito presente nos momentos mais alegres e, principalmente, nos mais difíceis. Na vida, à minha 
mestra de yoga, Síndia Bugiarda, meu obrigada por ter aliviado minhas crises de dor quando o estresse era insuportável e por ter me ensinado que o movimento que mais temo fazer é o que mais preciso.

Na família que não escolhi, mas que se pudesse certamente o faria, são muitos os agradecimentos. Obrigada Selma e Omar, mãe e pai, por terem me feito chegar até aqui e por terem aguentado com graça todas as minhas ausências. Obrigada, vó Jandyra, por ser minha mais fiel torcedora, mesmo sem entender totalmente o que eu estava fazendo - nem eu entendo às vezes. Juntos, todos vocês tornaram este trabalho possível, em um país onde a pesquisa é desvalorizada e as pesquisadoras também precisam do auxílio financeiro da família. Obrigada, Fernanda e Maria, irmã e afilhada, por fortalecerem meu ânimo nas pausas, pela presença alegre e barulhenta, sempre contribuindo para a manutenção da minha sanidade (e sempre por um fio!).

Sem vocês, sem tese. 


\section{Resumo}

Castro, Flávia Rodrigues de; Aguiar, Carolina Moulin (Orientadora). Refúgio e Injustiça Epistêmica: Uma Análise a partir do Brasil. Rio de Janeiro, 2020. 251p. Tese de Doutorado - Instituto de Relações Internacionais, Pontifícia Universidade Católica do Rio de Janeiro.

Esta tese é o resultado de uma pesquisa de inspiração etnográfica sobre o refúgio como prática de injustiça epistêmica, analisado por meio do universo brasileiro da elegibilidade e dos processos de produção de significados sociais. A concepção de injustiça epistêmica está relacionada a duas importantes práticas epistêmicas: produzir e compartilhar o conhecimento com outros por meio do testemunho e fazer sentido das próprias experiências sociais. A tese busca, assim, examinar a produção e a transmissão do conhecimento nos processos burocráticos da elegibilidade, isto é, na determinação do status de refugiado, e as formas de representação midiática em torno da figura do refúgio e seus sujeitos. Para tanto, a análise contou com uma pluralidade metodológica composta por trabalho de campo por meio da realização de entrevistas e abordagem com corpus através do uso de softwares específicos. A partir disso, a tese analisa o espaço das práticas epistêmicas que atravessam a categoria do refugiado e podem contribuir para a produção de injustiças, afetando a vida de solicitantes de refúgio e refugiados no Brasil.

\section{Palavras-chave}

Injustiça epistêmica; refúgio; elegibilidade; representação; Brasil. 


\section{Abstract}

Castro, Flávia Rodrigues de; Aguiar, Carolina Moulin (Advisor). Asylum and Epistemic Injustice in Brazil. Rio de Janeiro, 2020. 251p. Tese de Doutorado - Instituto de Relações Internacionais, Pontifícia Universidade Católica do Rio de Janeiro.

This thesis is the result of a research on asylum as epistemic injustice, analyzed through the Brazilian eligibility process and the practices of media representation in the country. The concept of epistemic injustice is intimately related to two crucial epistemic practices: conveying knowledge to others and making sense of our own social experiences. Hence, the two main aims of the research are the analysis of knowledge production in the bureaucratic process of eligibility (or refugee status determination process, RSD) and the investigation on how the Brazilian mainstream media represents refugees. To this end, the pluralistic research methods used consist of interview-based fieldwork and corpus linguistics with the help of specific software. The thesis therefore analyzes the space of epistemic practices that have an impact on the refugee category and may contribute to the production of injustices, affecting the lives of asylum seekers and refugees in Brazil.

\section{Keywords}

Epistemic injustice; asylum; eligibility; representation; Brazil. 


\section{Sumário}

1. Introdução 13

1.1. Contribuições da pesquisa 13

1.2. Condições da pesquisa 20

1.3. Organização do material 30

2. A injustiça epistêmica e o refúgio 36

2.1. Introdução 36

2.2. Relato de si e o encontro com o outro 39

2.3. A injustiça em contexto 55

2.4. O refúgio à luz da injustiça epistêmica 67

2.5. Conclusões 84

3. As práticas do refúgio por elegibilidade no Brasil: 88 burocracia e injustiça epistêmica

3.1. Introdução 88

3.2. O processo brasileiro de elegibilidade 93

3.3. O ritual de preenchimento do formulário 100

3.4. Os rituais de entrevista 107

3.5. Avaliando a credibilidade do solicitante 115

3.6. O GEP e o debate "técnico" 127

3.7. Conclusões 136

4. As práticas do refúgio por elegibilidade no Brasil: $\quad 140$

Percepções subjetivas e injustiça epistêmica
Introdução

4.2. O gerenciamento das expectativas no processo $\quad 144$

4.3. Vencer incoerências e convencer o outro 153

4.4. O papel da (des)confiança 160

4.5. O feeling sobre as histórias de refúgio: 168

4.6. Concepções sobre a condição refugiada 175

4.7. Conclusões 186

5. O campo semântico do refúgio no Brasil: A produção de 191 significados pela mídia e a injustiça epistêmica

5.1. Introdução 191

5.2. Estudos com corpus sobre a representação de 196 imigrantes e refugiados

5.3. A abordagem com corpus: guia para pesquisa 199

5.4. Resultados da análise léxica e gramatical 202

5.5. O campo semântico do refúgio no Brasil e a injustiça 219 hermenêutica

5.6. Conclusões 230 
6. Considerações finais

6.1. Refúgio e injustiça epistêmica 234

6.2. Refúgio e justiça epistêmica 240

7. Referências bibliográficas 246 


\section{Lista de Diagramas, Tabelas e Figuras}

Diagrama 1 - Processo de Solicitação de Refúgio 98

Diagrama 2 - Processo Decisório 99

Tabela 1 - Entrevistados Citados na Tese 23

Tabela 2 - Composição de cada subcorpus 203

Tabela 3 - Keywords por subcorpus 204

Tabela 4 - Collocates mais freqüentes do termo 205

"refugiad"”

Tabela 5 - Categorias e Termos Associados 206

Tabela 6 - Verbos dos quais o refugiado é sujeito 212

Tabela 7 - Freqüência por sujeito do discurso 214

Tabela 8 - Verbos dos quais o refugiado é objeto 215

Tabela 9 - Categorias e Termos Associados - 216

inclusão da categoria "controle"

Figura 1 - Distribuição das Categorias no corpus 211

Figura 2 - Distribuição das categorias no corpus - 218

inclusão da categoria "controle" 


\section{Lista de Siglas e Abreviaturas}

ACNUR: Alto Comissariado das Nações Unidas para Refugiados

ADUS: Instituto para a Reintegração do Refugiado - São Paulo

CDHIC: Centro de Direitos Humanos e Cidadania do Imigrante - São Paulo

CEIPARM: Comitê Estadual Intersetorial de Políticas de Atenção aos Refugiados e Migrantes - Rio de Janeiro

CEPRI: Centro de Proteção a Refugiados e Imigrantes da Casa Rui Barbosa - Rio de Janeiro

CONARE: Comitê Nacional para Refugiados - Brasil

CPMM: Centro Pastoral e de Mediação dos Migrantes - São Paulo

CPF: Código de Pessoa Física - Brasil

CRAI: Centro de Referência e Atendimento para Imigrantes - São Paulo

DPU: Defensoria Pública da União - Brasília

GEP: Grupo de Estudos Prévios (do CONARE)

IMDH: Instituto de Migrações e Direitos Humanos - Brasília

MJ: Ministério da Justiça - Brasil

RDC: República Democrática do Congo 


\section{Introdução}

Neste esforço introdutório busco situar a pesquisa em termos da sua contribuição original ao debate sobre o refúgio enquanto uma questão de injustiça epistêmica, indicando a importância de (re) pensar as práticas da elegibilidade e da representação como formas de refletir sobre as dimensões centrais do conceito de injustiça adotado aqui. Busco, ainda, expor de maneira detalhada as condições da pesquisa, discorrendo sobre as escolhas metodológicas (e éticas) e seus aspectos intrínsecos, com atenção especial ao trabalho de aproximação com o campo do refúgio no Brasil, realizado por meio de entrevistas. Por fim, abordo a estrutura geral da tese, salientando a organização do texto a partir da linha analítica utilizada para fins de ordenamento do material. O que procuro apresentar aqui compõe, então, minha história de pesquisadora.

\section{1}

\section{Contribuições da pesquisa}

Esta tese é o resultado de uma pesquisa de inspiração etnográfica sobre a produção epistêmica de sujeitos refugiados por meio do processo brasileiro de elegibilidade e das práticas de representação da mídia brasileira. $\mathrm{O}$ adjetivo epistêmico é utilizado aqui de forma a enfatizar a produção de conhecimento e de significados sociais sobre a experiência do refúgio. Nesse sentido, o interesse do trabalho é não só analisar as práticas de produção e transmissão do conhecimento nos processos burocráticos de determinação da condição refugiada, mas também as formas de representação midiática acerca da figura do refugiado e, assim, das experiências que a constituem. Interessa-nos a construção de um espaço éticoepistemológico que perpassa a categoria do refugiado e seus sujeitos, e que pode contribuir para a produção de injustiças epistêmicas que afetam as condições de possibilidade de comunicação da experiência do refúgio e da produção de significados e conhecimento a partir dessa condição refugiada. A perspectiva situada a partir do caso brasileiro foi adotada na pesquisa a fim de investigar um campo específico de forças sociais e de espaços de construção discursiva do refugiado que permitem a reflexão sobre um quadro social mais amplo de como se constitui o refúgio em suas relações paradoxais. Tornou-se relevante, assim, para os fins da pesquisa realizada, a análise sobre as formas diversas de operacionalização da categoria do refugiado, seja no âmbito da representação midiática, seja nos meandros hiper-racionalizados dos processos burocráticos de 
determinação do status. A categoria do refugiado depende não só de como este sujeito é produzido epistemicamente pelo sistema do refúgio por elegibilidade, mas também de como ele é construído nas formas de representação social no espaço midiático. Nesse sentido, torna-se fundamental refletir sobre a inteligibilidade da experiência do refúgio e sobre os significados atribuídos por meio da mídia àqueles que se encontram refugiados. Por outro lado, esta categoria também se encontra imersa em processos de hiper-racionalização que funcionam a partir de premissas e da expertise de determinados atores sobre o que constitui precisamente a experiência do refúgio. A partir disso, torna-se relevante analisar o lugar da elegibilidade como prática através da qual os significados pré-atribuídos à categoria do refugiado constituem-se como excesso que pode limitar a capacidade de escuta e participação mesmo no espaço do inteligível.

O esforço reflexivo almejado pela pesquisa abre espaço para uma discussão epistemológica sobre as práticas e políticas que estão na base das formas pelas quais o conhecimento sobre, para e com as populações refugiadas é adquirido - ou perdido. Busca-se, assim, investigar a dinâmica paradoxal que constitui a condição do refúgio, qua categoria, e dos refugiados, qua sujeitos: por um lado, a natureza incomunicável e de difícil tradução da experiência do refúgio e a consequentemente reduzida inteligibilidade sobre o que constitui o sujeito refugiado. Por outro, o excesso dos significados pré-atribuídos pelos processos de racionalização dessa experiência, evidenciados, por exemplo, pela dinâmica administrativa de atribuição do estatuto por atores governamentais e não-governamentais. Busco, assim, tomando como centro de referência essas relações paradoxais, a compreensão das práticas de produção de conhecimento e significados sobre o refúgio e seus sujeitos, entendendo-os como socialmente situados.

A análise do refúgio por elegibilidade no Brasil, como uma das dimensões cruciais da pesquisa, permite que repensemos a visão de excepcionalidade que perpassa o imaginário em termos de segurança e fronteiras (Doty, 2007; Huysmans, 2008, 2011), em direção às micro-práticas dispersas, aos "little nothings" (Huysmans e Nogueira, 2016), que desafiam a imagem dos oficias responsáveis exclusivamente por decidir em momentos pontuais e excepcionais (Huysmans, 2008). Como nos dizem Bigo e Walker (2007), qualquer decisionismo sob a forma schmittiana se revela arbitrário, descolado dos fluxos que constituem o espaço político. Essa abordagem permite, ainda, o abalo da aura de confidencialidade que 
cerca as práticas de fronteira e de concessão do status de refugiado, trazendo à tona as discordâncias, as lutas, as negociações e as interações íntimas entre diversos atores e locais do processo de elegibilidade. A partir disso, torna-se possível, então, focar nas relações entre agentes, posições e trajetórias nesse universo particular de forma a dar conta de sua rede complexa de fluxos (Huysmans e Nogueira, 2016). Nesse sentido, a perspectiva adotada aqui nos leva a um diálogo em potencial com a sociologia política internacional e seu foco nas micropráticas diárias, com atenção especial para as singularidades e especificidades, e não grandes narrativas e generalizações (Huysmans e Nogueira, 2016; Magalhães, 2016). Ao invés das estruturas, as relações (Bigo e Walker, 2007).

Cabe salientar, assim, a importância do estudo das práticas diárias, materiais e dotadas de significado social (Adler e Pouliot, 2011), que compõem as relações entre diversos atores e locais do refúgio por elegibilidade a fim de dar conta das atuações para além dos critérios legais e formais envoltos na determinação do status de refugiado. Conforme nos diz Saltsman (2014), há um consenso em emergência hoje sobre a importância de analisar o processo de determinação do status de refugiado já que este envolve a transformação da lei e da política em práticas. É possível identificar, assim, potencial conexão com a sociologia política internacional e a virada prática que procura estudar não as entidades, mas as práticas através das quais estas são criadas, reiteradas, modificadas e estabelecidas por meio de conexões (Huysmans e Nogueira, 2016). As práticas diárias das pequenas coisas permitem olhar para o processo substancial de determinação do status de refugiado, de análise de credibilidade e de estabelecimento de um regime de verdade e de prova que funcionam como práticas de fronteira que diferenciam entre quem é bemvindo e quem não é através da produção de significados sobre a categoria do refugiado.

Emerge como fundamental, então, a análise do refúgio por elegibilidade com a produção de significados ou premissas acerca da condição refugiada que pode ser vista como merecedora da proteção internacional por meio do estatuto do refúgio. A partir disso, a pesquisa busca fazer contribuições ao levantar questionamentos que dizem respeito a uma das práticas mais importantes do refúgio por elegibilidade - a análise de credibilidade em torno do testemunho do solicitante. A maioria daqueles que solicitam refúgio não possui documentos para provar determinado temor de perseguição e, assim, todo o processo passa a depender do 
testemunho desses sujeitos (e da análise sobre ele) em termos de determinação da condição refugiada no país de destino. O processo de elegibilidade, que tem na análise de credibilidade do testemunho um dos seus pontos-chave, se torna, então, uma investigação sobre a verdade no solicitante. Torna-se fundamental, assim, a análise da produção do conhecimento nos julgamentos de credibilidade em seu contexto de poder, com os aspectos políticos da conduta epistêmica daqueles envolvidos na determinação do status de refugiado. Trata-se, conforme critica Fricker (2007), não de uma proposta de análise epistêmica tradicional que concebe os atores em abstração das relações de poder, mas de uma busca por compreender as práticas epistêmicas do refúgio por elegibilidade a partir do seu contexto "socialmente situado" (Haraway, 1988).

Para além do foco nas práticas locais de produção de significados no processo do refúgio por elegibilidade e, portanto, da produção do refugiado enquanto categoria burocrática, a pesquisa também trouxe a relevância de uma escolha narrativa cujo enfoque recaia sobre as políticas (também locais) de representação. A partir da análise sobre o espaço ocupado pelo refugiado na mídia do país, é possível lançar luz sobre alguns aspectos centrais dentro de um quadro de representação do refúgio, como: a obsessão por números como forma de quantificar os fluxos; o vínculo nacional como fator essencial de referência à condição refugiada; e a localização da categoria do movimento entre imagens do cuidado e do controle. Este último aspecto, em específico, traz à tona a possibilidade de reflexão sobre a representação pública de seres humanos que devem ou não ser defendidos, com uma possível oscilação entre estes sujeitos enquanto objetos de repressão e de compaixão, nos termos inicialmente propostos por Fassin (2005). Nesse sentido, emerge a possibilidade de análise dos processos públicos de construção de uma categoria sociológica do refugiado enquanto vítima, mas também enquanto solicitante de refúgio clandestino ou ilegal, com a imagem da oscilação entre repressão e compaixão trazida por Fassin (2005).

Uma análise das práticas de representação dos refugiados pela mídia brasileira permite, assim, refletir sobre a possibilidade de processos de vitimização e marginalização desses sujeitos, já apontados em discussões teóricas mais amplas (Boltanski, 1999; Fassin, 2005, 2007; Soguk, 1999). Como forma de contribuição original, porém, a ênfase da pesquisa é desenvolvida em paralelo com discussões sobre marginalização e exclusão epistêmica dos sujeitos refugiados, podendo 
refletir na produção de uma injustiça do tipo hermenêutico. Nesse sentido, mais do que analisar o deslocamento como espaço pastoral, do cuidado caritativo e da política da piedade (Boltanski, 1999), com processos de vitimização que buscam apagar voz, face e agência (Soguk, 1999), o objetivo é refletir sobre a homogeneização da figura do refugiado e a sua ausência na produção de significados sobre a sua própria condição sócio-política. A idéia de marginalização hermenêutica oferece, então, um instrumento analítico poderoso para compreendermos processos de exclusão dos refugiados em regimes epistêmicos para além das trocas testemunhais restritas ao refúgio por elegibilidade.

Buscar compreender os lugares sociais possíveis de habitação para o refugiado levanta a potencialidade de contribuirmos com as discussões sobre a chamada "vida biográfica", que é comumente vivida por um sujeito, mas narrada por outro (Fassin, 2007). Tal distinção entre as vidas que podem ser narradas em primeira pessoa e as vidas que só podem ser narradas em terceira pessoa trazem, segundo Fassin, a questão de uma desigualdade ontológica entre os sujeitos. Apesar da importância desse debate, a presente pesquisa propõe contribuir com uma perspectiva que considere, primordialmente, uma possível desigualdade epistêmica, cujo enfoque não recaia sobre a ontologia do sujeito refugiado, mas sobre suas práticas epistemológicas - ao invés da ênfase ontológica sobre as vidas refugiadas, uma ênfase epistêmica sobre as narrativas desses sujeitos e suas próprias condições de possibilidade. Articula-se, a partir disso, não somente a possibilidade de análise de uma injustiça epistêmica, baseada em uma desigualdade mais ampla e fundamental entre os sujeitos e a validade dos seus testemunhos, como também do potencial intrínseco de toda representação como uma forma de poder (Chouliaraki, 2013).

A ênfase da pesquisa sobre processos de produção de conhecimento e significados sociais sobre a experiência do refúgio traz à tona a possibilidade de pensar o tema a partir do conceito de injustiça epistêmica. Conforme procuro salientar na introdução do primeiro capítulo, embora seja possível compreender o refúgio a partir da lente de produção de justiça por meio do fortalecimento da proteção internacional aos sujeitos abarcados pelo estatuto, o foco da pesquisa não está voltado a reflexões no campo da filosofia do direito. O que busco analisar diz respeito, então, às práticas epistêmicas que atravessam o campo do refúgio e ajudam a produzir sujeitos refugiados - e o que isso pode significar em termos de uma 
injustiça essencialmente epistêmica. Diante disso, emerge o interesse central em refletir sobre discussões ético-epistemológicas acerca de uma injustiça relacionada ao "mal causado a alguém em sua capacidade enquanto um sujeito de conhecimento e, assim, em uma capacidade essencial para o valor humano" (Fricker, 2007, p.5). A pesquisa parte, assim, de um conceito teórico-filosófico central de injustiça epistêmica que está relacionado a duas práticas ${ }^{1}$ diárias básicas: transmitir conhecimento ao outro por meio do testemunho e fazer sentido das próprias experiências sociais (também comunicando tais experiências de maneira inteligível ao outro).

As práticas epistêmicas podem produzir, assim, duas formas interligadas de injustiça epistêmica: a injustiça testemunhal e a injustiça hermenêutica. A primeira, segundo Fricker (2007), constitui-se como um ataque direto à autoridade epistêmica daquele que narra ou testemunha algo e à sua capacidade enquanto sujeito do conhecimento. Já a segunda é produzida em um quadro de desigualdade no qual os sujeitos que pertencem a grupos socialmente marginalizados acabam tornando-se também marginalizados hermeneuticamente (Fricker, 2007). Nesse sentido, aqueles que sofrem a injustiça hermenêutica participam de maneira desigual nas práticas pelas quais os significados sociais são gerados, o que pode resultar na produção de conceitos inadequados para fazer sentido de suas experiências sociais (ou, ainda, em uma não produção desses conceitos). Assim, enquanto na injustiça testemunhal teríamos alguém injustiçado na sua capacidade como sujeito do conhecimento, na injustiça hermenêutica teríamos alguém injustiçado em sua capacidade como sujeito da compreensão social (Fricker, 2007).

Para os fins da presente pesquisa, interessa também analisar, como já sugere Fricker, a possível interligação entre os dois tipos de injustiça epistêmica, buscando identificar pontos de encontro e articulação entre a injustiça testemunhal e a injustiça hermenêutica. A manifestação mais comum da injustiça hermenêutica através da luta do sujeito que narra em tornar seu testemunho inteligível levanta a seguinte possibilidade: "a injustiça hermenêutica pode ser composta pela injustiça testemunhal" (Fricker, 2007, p.159). Para Fricker, é possível que este seja o caso quando a injustiça hermenêutica ganha contornos sistemáticos, com a sujeição de múltiplos grupos marginalizados ao preconceito identitário estrutural. O

${ }^{1}$ Denominadas, então, de práticas epistêmicas, conforme nos diz Fricker (2007). 
testemunho de um sujeito pode ter sua credibilidade negativamente afetada tendo em vista a baixa inteligibilidade que já toca a vida deste mesmo sujeito no âmbito do social. Assim, a injustiça epistêmica pode se desenvolver tanto pelo preconceito estrutural nos recursos hermenêuticos compartilhados quanto pelo preconceito no julgamento da credibilidade, por exemplo.

Tendo, então, como instrumento teórico-conceitual de análise, a noção de injustiça epistêmica, a pesquisa propõe contribuir com o debate em torno das práticas de produção de conhecimento e significados sociais sobre a experiência do refúgio. $\mathrm{O}$ olhar da pesquisa recai aqui sobre a produção epistêmica de sujeitos pelo sistema, tanto na esfera do refúgio por elegibilidade, com uma dimensão testemunhal da injustiça, quanto na esfera da representação midiática, com uma dimensão hermenêutica da injustiça. É importante destacar, porém, que ambas as dimensões da injustiça epistêmica encontram-se interligadas, apesar do esforço analítico em apresentá-las didaticamente durante o texto. Nesse sentido, mesmo na análise dos processos brasileiros de elegibilidade será possível abordar a dimensão hermenêutica da injustiça, ainda que a ênfase de tal discussão esteja sobre o aspecto testemunhal das práticas analisadas. De maneira geral, então, a análise sobre os processos e mecanismos de determinação da condição refugiada pelo sistema da elegibilidade ressalta a importância do debate sobre o espaço das trocas testemunhais e das análises de credibilidade em consonância, principalmente, com a chave interpretativa da injustiça testemunhal. Já a reflexão sobre formas de representação midiática da experiência do refúgio e, assim, dos seus sujeitos, busca trazer à tona o debate sobre marginalização e exclusão epistêmica e as suas implicações em termos de uma injustiça hermenêutica.

Nas análises do refúgio por elegibilidade, então, ganha papel de destaque o funcionamento das avaliações de credibilidade, bem como o papel de estereótipos, preconceitos e percepções subjetivas sobre os solicitantes de refúgio. Nas diferentes etapas do processo de determinação do status de refugiado, é possível refletir sobre a existência de obstáculos à participação dos solicitantes como sujeitos do conhecimento, ao mesmo tempo em que vemos emergir um papel proeminente atribuído à expertise dos "técnicos do refúgio"2", responsáveis por julgar a

\footnotetext{
${ }^{2}$ A expressão "técnicos do refúgio" é utilizada durante a tese tendo em vista a autoidentificação de alguns dos entrevistados, especialmente em referência aos sujeitos participantes do chamado Grupo de Estudos Prévios e à realização das análises de credibilidade.
} 
credibilidade, determinar a força e a fraqueza dos casos e tomar decisões. O objetivo das análises é refletir, assim, sobre como as práticas da elegibilidade podem contribuir para a produção de uma injustiça epistêmica que recai sobre os sujeitos em busca de refúgio.

As discussões sobre o processo de elegibilidade também são atravessadas pela dimensão hermenêutica da injustiça epistêmica, tendo em vista a possibilidade de sua manifestação nas trocas testemunhais. Porém, uma reflexão voltada às questões hermenêuticas no quadro da injustiça é desenvolvida em maiores detalhes no capítulo final, com questionamentos a respeito da baixa inteligibilidade que já toca a vida dos sujeitos em situação de refúgio no âmbito do social. Tendo isso em mente, torna-se necessário refletir sobre a inteligibilidade da experiência do refúgio através dos significados atribuídos pela mídia brasileira aos refugiados. Busco analisar, então, como a injustiça epistêmica não se restringe aos espaços da elegibilidade, podendo determinar a imagem do refúgio para além dos processos oficiais de determinação do status.

\section{2 \\ Condições da pesquisa}

A pesquisa foi conduzida a partir de métodos plurais compostos por trabalho de campo por meio da realização de entrevistas e análise com corpus através do uso de softwares específicos ${ }^{3}$. O levantamento de um corpo bibliográfico foi realizado a fim de auxiliar o desenvolvimento do capítulo inicial da tese, que propõe explorar o campo de debates em torno do conceito teórico-filosófico da injustiça epistêmica e do refúgio compreendido à luz do mesmo. Nesse sentido, busco não só expor as idéias originais sobre injustiça epistêmica, como também engajar-me com o diálogo neste campo a partir das críticas e questionamentos de autores diversos. Não menos importante, procuro analisar as produções teóricas voltadas ao refúgio, especialmente em sua dimensão da análise de credibilidade, a fim de criar possibilidades de reflexão sobre o tema de forma articulada com o conceito de

\footnotetext{
${ }^{3}$ A abordagem da pesquisa com corpus através do uso de softwares foi utilizada apenas na análise midiática tendo em vista a extensão do material coletado (totalidade de 1.145 arquivos de texto no formato de artigos/matérias de jornais e portais de notícias). Foi necessária, assim, a combinação entre análise qualitativa e análise quantitativa promovida pelas ferramentas tecnológicas empregadas.
} 
injustiça epistêmica. Embora o arcabouço teórico seja constantemente retomado no decorrer de toda a análise, reposicionado de forma a compor com o material das entrevistas, considero que seu eixo central está desenvolvido nesta primeira etapa que introduz o leitor à perspectiva aqui desenvolvida.

A pesquisa de campo por meio da realização de entrevistas constitui a parte fundamental da análise, uma vez que, a partir dela, foi possível compreender práticas centrais do processo brasileiro de elegibilidade. É preciso ter em mente aqui a aura de confidencialidade e sigilo que marca o campo da determinação do status de refugiado no país e impede, assim, o acompanhamento, por parte dos pesquisadores, das práticas decisórias e dos espaços coletivos de debate sobre os casos. Nesse sentido, considero relevante ressaltar a impossibilidade do meu acesso a pareceres oficiais sobre as solicitações de refúgio, aos áudios das entrevistas de elegibilidade, bem como aos documentos produzidos para embasar alguns dos posicionamentos dos atores deste universo burocrático. Embora eu tenha tido acesso, como voluntária de uma organização da sociedade civil, a todo este material, meu próprio status à época não era de pesquisadora e, portanto, nenhum documento ou informação relativa aos casos acessados enquanto voluntária foi utilizado durante a pesquisa. Por outro lado, a minha inserção como voluntária na organização, entre 2015 e 2017, permitiu não só que eu ganhasse conhecimento sobre algumas das práticas centrais do processo de elegibilidade, como também abriu caminho para que eu pudesse estabelecer redes de contato (e afeto) que foram fundamentais para a condução das entrevistas.

Para mim, o prolongamento no campo na condição de voluntária, a minha presença em reuniões formais e informais, bem como o apoio às lutas diárias de refugiados e funcionários ajudaram a desenvolver um tipo de relação marcada pelo engajamento e pela confiança o que, por sua vez, facilitou as renegociações da minha posição, do meu acesso e da condução da minha pesquisa. Sendo reconhecida como ex-voluntária da Cáritas-Rio, muitos atores deste universo institucional se dispuseram a me receber e a serem entrevistados, inclusive indicando - quase sempre - novos nomes e contatos aos quais eu ainda não tinha acesso e poderia recorrer para a realização de novas entrevistas. Da mesma forma, o acesso aos refugiados e solicitantes de refúgio foi facilitado por essa inserção precedente em organização da sociedade civil, uma vez que pude recorrer a pessoas que já conhecia e que, novamente, por sua vez, indicaram novos nomes com quem 
eu poderia entrar em contato. A condição de ex-voluntária foi importante, assim, para aumentar as possibilidades de acesso aos sujeitos entrevistados, bem como para legitimar o meu interesse no tema. Grande parte das interações partiu de uma ausência de questionamentos sobre a escolha do tema da pesquisa, parecendo naturalizar o fato de que minha inserção inicial no campo como voluntária fez surgir um interesse em analisar as práticas da elegibilidade no país.

A naturalização deste interesse em função da minha inserção prévia foi lida, em alguns casos, como uma não-necessidade de me contar detalhes dos processos, uma vez que alguns dos atores consideravam que eu já sabia o funcionamento e as dinâmicas do universo institucional. Foi necessário, diante disso, manter o estranhamento em relação aos processos de refúgio, buscando não intervir em falas a partir da minha própria experiência e subjetividade, mas apreender as perspectivas dos entrevistados e lembrá-los de que suas visões constituíam o interesse central da interação. Um desafio importante na condução das entrevistas emergiu, então, dos encontros com entrevistados que haviam trabalhado comigo enquanto eu era voluntária na organização da sociedade civil e tendiam a não entrar em detalhes sobre dinâmicas que, segundo eles, eu já compreendia. Conforme busco explicitar na introdução do segundo capítulo, foi fundamental propor o exercício de estranhamento, quebrando minha familiaridade com as práticas analisadas e permitindo a escuta das perspectivas dos sujeitos sobre o processo e seu papel nele.

Nesta atuação no campo, realizei um total de cinqüenta e duas entrevistas, entre Julho de 2018 e Abril de 2019, com solicitantes de refúgio e refugiados, oficiais de elegibilidade e funcionários de instituições que compõem o Comitê Nacional para Refugiados (CONARE) e atuam com o tema no Rio de Janeiro, em São Paulo e em Brasília. Cabe indicar aqui o fato de que nem todas as entrevistas são citadas nesta tese, tendo em vista a necessidade de realização de recortes ${ }^{4} \mathrm{e}$ organização do extenso material de pesquisa. Na tabela abaixo busco detalhar os entrevistados citados aqui, a partir das informações relacionadas ao pseudônimo utilizado, à instituição ou status migratório associados ao sujeito, bem como à data, à duração e ao meio de realização da entrevista.

\footnotetext{
${ }^{4}$ Recortes foram feitos de forma a preservar o interesse da pesquisa nas práticas da elegibilidade e evitar repetições nas análises. Cabe ressaltar, ainda, que não procuro dar conta de todos os detalhes e procedimentos da concessão do refúgio no Brasil, tendo em vista a impossibilidade da tarefa. Ressalto, assim, linhas de argumentação construídas por mim e que não desconsideram a subjetividade intrínseca às práticas de produção de conhecimento.
} 
Tabela 1: Entrevistados Citados na Tese

\begin{tabular}{|c|c|c|c|c|}
\hline Pseudônimo & $\begin{array}{c}\text { Instituição/Status } \\
\text { Migratório }\end{array}$ & Data & Duração & Meio \\
\hline Sofia & Cáritas-Rio & $23 / 08 / 2018$ & $52 \mathrm{~min}$ & Presencial \\
\hline Júlio & Cáritas-Rio & $25 / 09 / 2018$ & $1 \mathrm{~h} 58 \mathrm{~min}$ & Presencial \\
\hline Fernando & Cáritas-Rio & $19 / 09 / 2018$ & $57 \mathrm{~min}$ & Presencial \\
\hline Beatriz & Cáritas-Rio & $21 / 09 / 2018$ & $50 \mathrm{~min}$ & Presencial \\
\hline Camila & Cáritas-Rio & $20 / 08 / 2018$ & $1 \mathrm{~h} 18 \min$ & Presencial \\
\hline Cecília & Cáritas-Rio & $27 / 07 / 2018$ & $58 \mathrm{~min}$ & Presencial \\
\hline Maria & Cáritas-Rio & $26 / 07 / 2018$ & $1 \mathrm{~h} 11 \mathrm{~min}$ & Presencial \\
\hline Manuela & Cáritas-Rio & 01/08/2018 & $33 \mathrm{~min}$ & Presencial \\
\hline & & & & \\
\hline
\end{tabular}




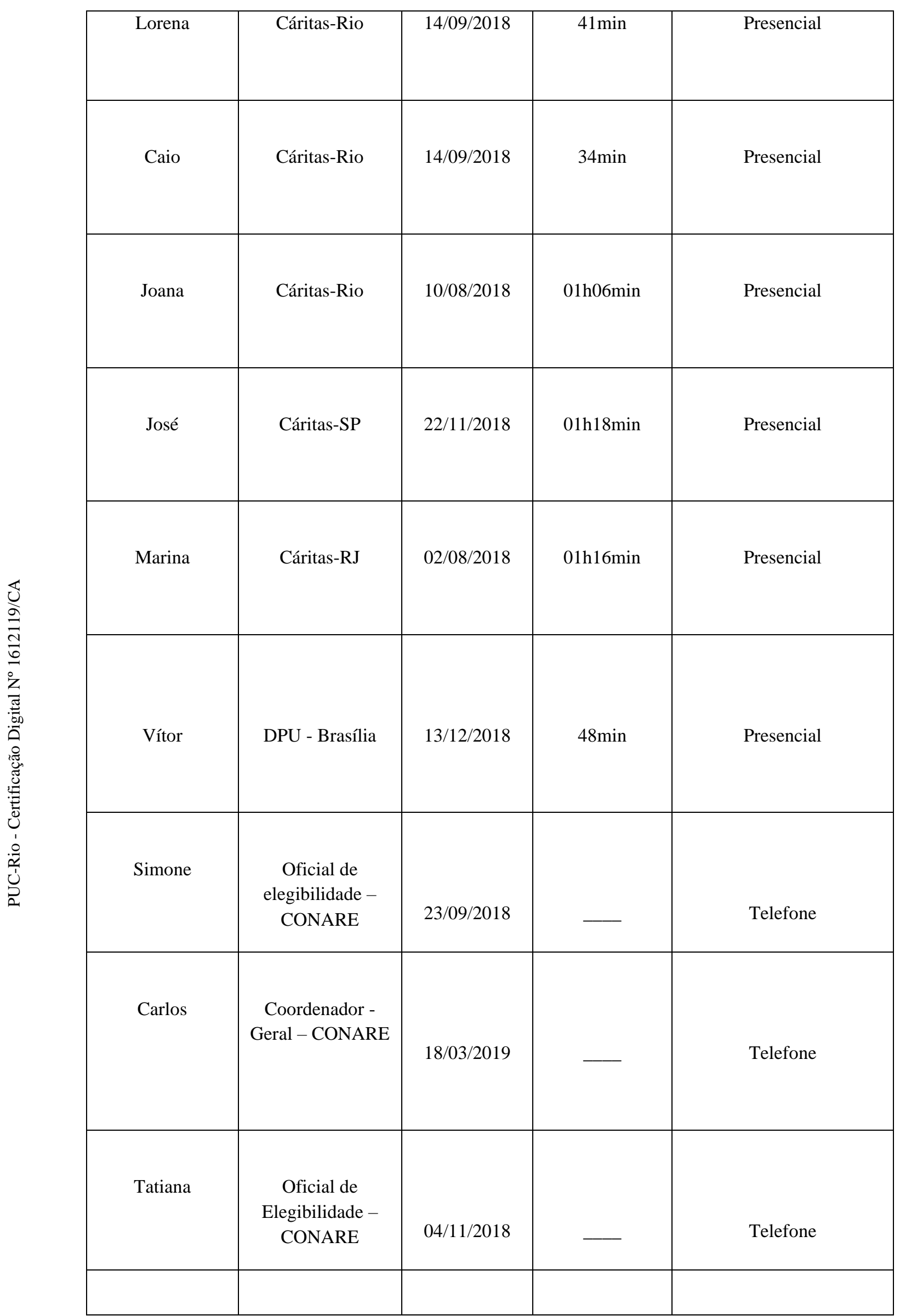




\begin{tabular}{|c|c|c|c|c|}
\hline Jorge & $\begin{array}{c}\text { Polícia Federal - } \\
\text { RJ }\end{array}$ & $12 / 12 / 2018$ & $38 \mathrm{~min}$ & Presencial \\
\hline Vanessa & Cepri - RJ & $10 / 09 / 2018$ & $38 \mathrm{~min}$ & Presencial \\
\hline Laís & Missão Paz - SP & $07 / 12 / 2018$ & - & Telefone \\
\hline Javier & $\begin{array}{c}\text { Solicitante - } \\
\text { Venezuela }\end{array}$ & $23 / 11 / 2018$ & $35 \mathrm{~min}$ & Presencial \\
\hline Patrick & Refugiado - RDC & $17 / 04 / 2019$ & $31 \mathrm{~min}$ & Presencial \\
\hline Dimitri & $\begin{array}{l}\text { Solicitante - } \\
\text { Rússia }\end{array}$ & $16 / 04 / 2019$ & $1 \mathrm{~h} 34 \mathrm{~min}$ & Presencial \\
\hline Samir & Refugiado - Síria & $17 / 04 / 2019$ & $01 \mathrm{~h} 45 \mathrm{~min}$ & Presencial \\
\hline Ahmed & $\begin{array}{l}\text { Solicitante - } \\
\text { Marrocos }\end{array}$ & $20 / 10 / 2018$ & $51 \mathrm{~min}$ & Presencial \\
\hline Tresor & Solicitante - RDC & $26 / 02 / 2019$ & $32 \mathrm{~min}$ & Presencial \\
\hline & & & & \\
\hline
\end{tabular}




\begin{tabular}{|l|c|c|c|c|}
\hline Plamedi & Solicitante - RDC & 26/02/2019 & $31 \mathrm{~min}$ & Presencial \\
\hline & & & & \\
Guelor & Refugiado - RDC & $25 / 10 / 2018$ & $58 \mathrm{~min}$ & Presencial \\
& & & & \\
\hline
\end{tabular}

Conduzi, assim, entrevistas semiestruturadas com alguns dos principais atores do universo brasileiro do refúgio por elegibilidade, em formato de questionário semiaberto, com um roteiro previamente elaborado, mas de modo a permitir a amplitude de respostas e divagações dos sujeitos. Quanto ao teor das entrevistas, em relação aos funcionários e voluntários de instituições governamentais e da sociedade civil, foram levantados questionamentos acerca da experiência dos atores no campo do refúgio, as atividades e rotinas desenvolvidas nas respectivas instituições, os treinamentos recebidos para atuação na área, o contato com outros atores do sistema brasileiro de refúgio e os diversos espaços e momentos de interação com refugiados e solicitantes Quanto a estes últimos, foram realizados questionamentos acerca das suas experiências de mobilidade e vida no Brasil, do processo de solicitação do refúgio, das interações com diferentes atores da sociedade e do governo brasileiro que atuam nas instituições supracitadas, assim como interações mais difusas no país.

No Rio de Janeiro, pude entrar em contato com algumas instituições e atores que desempenham papel central no processo brasileiro de elegibilidade. Na CáritasRio, em seu programa de atendimento a refugiados e solicitantes, entrevistei funcionários e voluntários dos setores de proteção legal e elegibilidade, de assistência social, de psicologia e de acolhimento - além, é claro, da coordenação e diretoria da instituição. No Centro de Proteção a Refugiados e Imigrantes da Casa Rui Barbosa (CEPRI), entrevistei a coordenação do programa, assim como alguns advogados e funcionários que atuam como agentes de proteção legal. No Departamento de Polícia Federal, entrevisteis atores que trabalham no aeroporto e são encarregados de atender diretamente refugiados e solicitantes de refúgio. $\mathrm{Na}$ Defensoria Pública do Estado do Rio de Janeiro, entrevistei os funcionários responsáveis por atender às demandas da população refugiada. Atores de outras 
instituições, como a Cruz Vermelha e o Comitê Estadual Intersetorial de Políticas de Atenção aos Refugiados e Migrantes (CEIPARM-RJ), foram entrevistados, embora tenham pouca participação no processo de elegibilidade.

Em São Paulo, através da realização de viagens pontuais, em 2018 e 2019, conduzi entrevistas com funcionários de instituições também centrais no processo de elegibilidade. Na Cáritas-SP, entrevistei funcionários dos setores de proteção legal e elegibilidade e de acolhimento. Na Missão Paz, mais especificamente no Centro Pastoral e de Mediação dos Migrantes (CPMM), entrevistei funcionários responsáveis pelo atendimento jurídico e que orientam, assim, algumas práticas importantes para a pesquisa, como o preenchimento do formulário de refúgio e a condução de entrevistas. Em relação à Defensoria Pública do Estado de São Paulo, a entrevista foi realizada por telefone com funcionários que prestam atendimento jurídico aos solicitantes e refugiados. No Centro de Direitos Humanos e Cidadania do Imigrante (CDHIC), entrevistei funcionários responsáveis por atendimentos sociais e relacionados à documentação de refugiados e imigrantes. No Centro de Referência e Atendimento para Imigrantes (CRAI), entrevistei funcionários que prestam atendimento jurídico e social aos refugiados, solicitantes e imigrantes. E, por último, no Instituto para a Reintegração do Refugiado (ADUS), as entrevistas foram conduzidas com funcionários do acolhimento e do atendimento jurídico a refugiados e solicitantes de refúgio.

Já em relação à Brasília, todas as entrevistas foram conduzidas por telefone - apenas em um dos casos houve um encontro presencial, quando o entrevistado esteve presente no Rio de Janeiro. A coordenação do CONARE e alguns de seus oficiais de elegibilidade foram entrevistados a respeito do processo e de sua atuação nele. No que diz respeito à Defensoria Pública da União, foram entrevistados atores responsáveis pela defesa de solicitantes e refugiados no processo de elegibilidade e que participam diretamente dos espaços coletivos de debate.

O contato com solicitantes e refugiados foi realizado tanto a partir de encontros em instituições, como a Cáritas-Rio, Cáritas-SP e Instituto ADUS, como a partir das indicações dos próprios sujeitos de outras pessoas que poderiam contribuir com a pesquisa. Todas as entrevistas com refugiados e solicitantes foram realizadas pessoalmente, seja no Rio de Janeiro, seja em São Paulo. Em alguns casos, as entrevistas foram conduzidas em aeroportos enquanto os refugiados e solicitantes buscavam atendimento - mas sempre a partir da mediação de outros 
refugiados que já me conheciam e me apresentaram àqueles que estavam dispostos a falar comigo. Todas as entrevistas foram conduzidas em português, ainda que eu tenha deixado a critério dos entrevistados a escolha do idioma (em casos de uso do espanhol, inglês ou francês) - grande parte deles demonstrou interesse em contribuir em português de modo a treinar a proficiência no idioma. De modo geral, então, as entrevistas foram conduzidas em localidades diversas nos dois estados aeroportos, cafés, instituições e, em alguns casos, na casa dos próprios entrevistados que optaram por me receber generosamente em seus lares. Ao todo, foram entrevistados solicitantes e refugiados de sete países: República Democrática do Congo, Síria, Rússia, Marrocos, Angola, Venezuela e Colômbia. Não houve escolha direcionada de nacionalidades - o contato com pessoas provenientes destes países foi feito de forma espontânea, a depender do acionamento das redes e da disponibilidade dos sujeitos.

Quanto à confidencialidade e condições relativas à participação dos entrevistados, cabe salientar aqui que a pesquisa foi aprovada pelo Comitê de Ética em Pesquisa da PUC-Rio, antes da realização de qualquer entrevista. Todos os participantes foram informados, dentre outras coisas, do interesse geral do trabalho, da voluntariedade de sua participação, da possibilidade de interrupção da entrevista a qualquer momento, bem como da liberdade de escolha quanto à identificação. Grande parte dos entrevistados concordou com a gravação da entrevista e com a sua completa identificação. Apesar disso, e optando pela preservação da confidencialidade dos participantes, decidimos pela utilização de pseudônimos e mantemos a identificação apenas das instituições. A menção aos cargos ocupados pelos entrevistados só foi realizada em casos de funcionários vinculados ao Ministério da Justiça e Segurança Pública. Para fins de organização do material utilizado na tese, encontra-se disponibilizada a tabela dos entrevistados citados, com seus respectivos pseudônimos, instituição/status migratório, bem como data, duração e meio (presencial/por telefone) da entrevista.

Finalmente, foi realizada também uma análise com corpus a partir do uso de softwares e técnicas específicas que ajudaram a acessar e interpretar o material compilado dos jornais online e portais de notícias mais acessados no Brasil. Para tanto, em 2018 realizei um curso no Departamento de Letras da PUC-Rio a fim de que fosse possível empregar corretamente as técnicas de pesquisa para uma abordagem com corpus. A realização do curso proporcionou não somente o acesso 
às ferramentas específicas, mas também o próprio desenvolvimento da análise, que pôde contar com a contribuição atenta daqueles que partilharam os encontros. Dessa maneira, o capítulo final da tese é produto das trocas e esforços analíticos desenvolvidos no curso, durante o qual apresentei semanalmente os avanços das análises e as dificuldades encontradas com os programas e a compilação do material. A pesquisa realizada só foi possível, então, graças ao uso de uma metodologia desenvolvida nos estudos com corpus, com programas auxiliares para a análise de uma coleção extensa de textos em formatos eletrônicos, bem como devido aos comentários e contribuições realizados nos encontros do curso. No último capítulo busco detalhar, assim, as escolhas e os critérios para delimitação do material de análise, tanto temporalmente quanto em relação aos portais e jornais acessados, expondo as condições da abordagem analítica e as especificidades da metodologia adotada.

Conforme procuro deixar claro no capítulo final, mesmo as análises que fazem uso de técnicas quantitativas são influenciadas pela subjetividade e interpretação da pesquisadora. Desde a escolha dos termos analisados e da criação de categorias, passando pelo fazer e refazer do texto no processo de criação que procura ordenar observações essencialmente caóticas, até a produção final de perspectivas sobre o material compilado: em todas essas etapas, há uma luta constante por ordenar o observado que não pode ser naturalizada como prerrogativa de uma pesquisadora privilegiada que observa tudo objetivamente. Não há, assim, a possibilidade de um olhar neutro, realizado a partir de lugar nenhum - ao invés disso, é preciso reconhecer que toda escrita é desenvolvida desde uma posição situada e particular (Haraway, 1988; Leander, 2015). As interpretações expostas e detalhadas na tese não precisam significar, assim, que a minha história de observadora é o retrato de uma realidade dada e objetiva a qual eu tenho acesso direto e, portanto, a melhor (e por vezes única) descrição. Aqui cabe enfatizar que qualquer descrição é uma tentativa de imposição da ordem sobre o que é potencialmente desordem na busca pela criação de significados particulares em meio a um universo de significados alternativos possíveis (Latour e Woolgar, 1986).

Mesmo na análise das entrevistas realizadas, considero a possibilidade de diferentes interpretações, a depender da posição subjetiva de cada ator e de discordâncias dos próprios entrevistados a respeito de como compreendi suas falas 
- embora tenha buscado tratar com seriedade cada um desses encontros ${ }^{5}$. Acredito ser preciso, então, abandonar tentativas de afirmar o conhecimento como algo que eu transcrevo do mundo (ou do campo), para abraçar esforços de situar este conhecimento como algo que eu produzo, sempre em uma relação de diálogo e de troca com os atores no campo. A produção da pesquisa foi realizada, assim, a partir da busca por ordenar minhas observações, pensamentos e análises tendo em vista principalmente os encontros que tive durante o trabalho. Muitas das falas dos entrevistados pareceram apontar para a existência de um "estado de confusão generalizada" (Ordonez, 2008, p.40) que atravessa diversos funcionários e instituições do processo de elegibilidade, revelando que a confusão está longe de ser um estado restrito aos solicitantes e refugiados - embora, claro, impacte a vida dos sujeitos de maneira desigual. Mas se pude identificar um "estado de confusão generalizada", percebi também tentativas constantes de construir a ordem a partir dele, seja através das próprias práticas no processo de elegibilidade, seja por meio da sua comunicação em entrevista. Nesse sentido, tanto os participantes da pesquisa, quanto a própria pesquisadora, procuraram construir a ordem a partir da desordem, do caos ou do estado de confusão, desestabilizando possíveis assimetrias entre sujeito e objeto de pesquisa (Callon, 1986).

\section{3 \\ Organização do material}

A tese está dividida em quatro extensos capítulos, cada um deles respeitando a mesma estrutura composta por resumo, palavras-chave, introdução, desenvolvimento e conclusão. No primeiro capítulo abordo o arcabouço teórico que sustenta e perpassa as análises, apresentando não somente o conceito teóricofilosófico da injustiça epistêmica, mas também como é possível pensar o refúgio a partir da lente ético-epistemológica. Para tanto, tomo como contribuição central o trabalho desenvolvido por Miranda Fricker (1999, 2003, 2006, 2007, 2010) acerca

\footnotetext{
${ }^{5}$ Busco evitar aqui qualquer forma de "negação de autoria", que faz com que "o pesquisador procure se colocar como condutor neutro ao 'dar voz' aos observados" (Maton, 2003, p.55). As interpretações que realizo aqui podem não ser compartilhadas pelos próprios entrevistados, cuja voz só está presente nesta tese de forma mediada, recortada e organizada por mim mesma e pelas minhas escolhas metodológicas. Especialmente no que diz respeito às entrevistas realizadas com solicitantes e refugiados, é preciso evitar o que Spivak (2012) denomina de violência epistêmica, que permite que o intelectual se mascare como ausente das análises a fim de que os oprimidos falem por si mesmos.
} 
da injustiça epistêmica, sem deixar de trazer para a discussão as críticas e os questionamentos de outros teóricos que dialogam com a autora neste campo de análise. Inicio, assim, com uma reflexão sobre a dimensão testemunhal da injustiça epistêmica e o papel relevante que uma "economia da credibilidade", expressão cunhada por Fricker (2007), desempenha no espaço das trocas testemunhais. Abordo, posteriormente, a dimensão hermenêutica da injustiça epistêmica a fim de que seja possível refletir sobre um cenário sócio-político mais amplo no qual os sujeitos que pertencem a grupos socialmente marginalizados também podem tornarse hermeneuticamente marginalizados. Neste campo do debate teórico vemos emergir, então, as duas dimensões da injustiça epistêmica e as possibilidades de afastamento e aproximação entre elas.

A segunda parte do primeiro capítulo aborda as possibilidades de análise do refúgio à luz da injustiça epistêmica. Para isso, busco refletir sobre as práticas que constituem modos de verificação da verdade nas narrativas dos solicitantes de refúgio a fim de que lhe seja atribuído o status de refugiado. Vemos, assim, como a chamada "economia da credibilidade" (Fricker, 2007) também exerce papel central no refúgio por elegibilidade, no Brasil e no mundo. Ao abordar alguns aspectos relevantes nos julgamentos de credibilidade que determinam os sujeitos que devem ou não receber o status de refugiado, é possível compreender a importância das trocas testemunhais e os desafios que emergem em relação à inteligibilidade das narrativas dos solicitantes. Analiso, assim, as condições de possibilidade para a produção de uma injustiça epistêmica em um processo no qual algumas questões como confiança, estereótipos e preconceitos desempenham papel central na análise das solicitações de refúgio. Apesar da ênfase sobre as dinâmicas das trocas testemunhais, também busquei identificar um cenário estrutural mais amplo no qual as injustiças podem se reproduzir, ressaltando as desigualdades estruturais de poder e dificuldades que refugiados e solicitantes podem encontrar na busca por tornar inteligível determinadas experiências e participar ativamente na produção de conhecimento e significados sociais.

O capítulo inicial ajuda a delinear, então, as bases para a análise do processo brasileiro de elegibilidade que será realizada nos capítulos seguintes, bem como a reflexão mais ampla sobre a construção de significados sociais sobre a experiência do refúgio, realizada no último capítulo a partir de uma abordagem da mídia brasileira. Com isso em mente, o segundo capítulo é estruturado a partir das 
entrevistas realizadas com os atores que compõem o universo institucional do refúgio (Facundo, 2017) e com os sujeitos diretamente implicados nas práticas da elegibilidade - solicitantes de refúgio e refugiados. Proponho uma reflexão detalhada sobre o processo de formação (e atuação) da burocracia de determinação do status no Brasil, apresentando em linhas gerais o refúgio por elegibilidade e desenvolvendo alguns aspectos centrais das suas práticas constitutivas. Analiso, assim, diferentes etapas do processo brasileiro de elegibilidade a partir das narrativas dos entrevistados e da minha própria experiência no campo, ressaltando os rituais de preenchimento do formulário de refúgio, as entrevistas de elegibilidade, as análises de credibilidade e os debates em espaços coletivos que antecedem a reunião decisória.

A partir das análises desenvolvidas neste capítulo, proponho uma reflexão sobre dois aspectos fundamentais que perpassam as diferentes etapas analisadas e que contribuem para questionamentos a respeito de um quadro de injustiça epistêmica. O primeiro deles é o gradual desaparecimento do solicitante de refúgio no processo, com práticas que contribuem para desapropriar as narrativas - desde a transformação da vida em documento burocrático até o papel predominante da expertise dos "técnicos do refúgio", responsáveis pelos julgamentos de credibilidade. Sob a lente da injustiça epistêmica, busco enfatizar a marginalização e exclusão epistêmica dos solicitantes e refugiados das práticas de produção e transmissão do conhecimento, bem como da participação ativa enquanto sujeitos no processo. O segundo aspecto que atravessa as diferentes etapas é o papel central que uma "economia da credibilidade" (Fricker, 2007) exerce no processo, trazendo à tona a relação entre excessos e déficits de credibilidade, bem como a existência de um privilégio epistêmico desfrutado por determinados atores. Vemos, então, como uma posição epistemicamente privilegiada pode contribuir para minar a credibilidade dos solicitantes ao considerarmos a natureza interativa das práticas de análise de credibilidade e o papel de estereótipos e preconceitos em julgamentos realizados a partir de uma determinada perspectiva privilegiada.

Se no segundo capítulo procurei trabalhar com os aspectos considerados mais formais e objetivos do refúgio por elegibilidade, ainda que já questionasse a atuação da burocracia, no terceiro capítulo proponho uma análise voltada para aspectos subjetivos do mesmo processo. É importante ter em mente que tal separação entre aspectos formais e burocráticos, de um lado, e dimensões 
subjetivas, de outro, foi realizada para fins puramente didáticos. Conforme procurei explicitar no decorrer do texto, as falas dos entrevistados trouxeram tais aspectos em conjunto e ajudaram a entender o caráter de complexidade que atravessa todo o processo. A partir deste esforço de organização do material, o terceiro capítulo se debruça sobre as práticas da elegibilidade desde as percepções subjetivas dos atores e sua articulação com um possível quadro de injustiça epistêmica. Proponho, assim, uma análise de como os diferentes sujeitos percebem o processo de determinação da condição refugiada e sua própria participação nele. Para isso, ressalto algumas dinâmicas centrais trazidas pelos entrevistados, como a busca pelo gerenciamento de expectativas, por vencer incoerências e convencer o outro, o exercício da (des) confiança, a gestão das emoções sobre as "histórias de refúgio" e a articulação de significados diversos sobre o que constitui a figura do refugiado.

As reflexões propostas neste terceiro capítulo também ressaltam a manutenção de uma estrutura em que a confiança na capacidade explicativa de determinados atores institucionais é acompanhada por uma desconfiança na capacidade dos solicitantes para produzir e transmitir conhecimento a partir de suas próprias experiências pessoais. No conjunto das práticas analisadas, ganha destaque o papel das percepções subjetivas nos julgamentos de credibilidade, o que traz à tona a importância não só de estereótipos e preconceitos em uma "economia da credibilidade" (Fricker, 2007), mas também das reações emocionais na troca testemunhal. Nesse sentido, vemos, assim como no capítulo anterior, a existência de uma restrição ao conhecimento dos solicitantes e refugiados, com obstáculos a sua participação ativa enquanto sujeito no processo. Além das práticas de marginalização e exclusão epistêmica, também vemos emergir novamente aqui a existência de posições de privilégio epistêmico. Porém, diferentemente do capítulo anterior, a ênfase da análise recai sobre os aspectos subjetivos que impactam o refúgio por elegibilidade e contribuem para ampliar o entendimento sobre um quadro de injustiça epistêmica que não se restringe à atuação de preconceitos, mas também pode encontrar força no papel que emoções e percepções desempenham no julgamento do solicitante crível.

Por fim, o último capítulo desta tese busca analisar, em maiores detalhes, como obstáculos à inteligibilidade das experiências dos sujeitos refugiados e à sua participação na produção de significados e transmissão de conhecimento não estão restritos às práticas da elegibilidade, mas encontram terreno fértil no campo 
midiático. Dessa maneira, para além de uma reflexão sobre um quadro de injustiça epistêmica nas trocas testemunhais com os solicitantes de refúgio, procuro analisar a possibilidade de uma injustiça hermenêutica nas práticas de representação midiática do refugiado. Ainda que as discussões dos capítulos anteriores perpassem o terreno da dimensão hermenêutica da injustiça epistêmica, é preciso ter em mente que a ênfase das análises recai sobre a manifestação testemunhal da injustiça no refúgio por elegibilidade. Tendo isso em mente, considero relevante, para a compreensão do refúgio à luz da injustiça epistêmica, um debate mais detalhado sobre a baixa inteligibilidade que já toca a vida dos sujeitos em um cenário mais amplo e para além das práticas - burocráticas e subjetivas - de determinação do status. Nesse sentido, proponho refletir sobre a inteligibilidade da experiência do refúgio através dos significados atribuídos pela mídia brasileira aos refugiados.

O último capítulo está voltado, então, para a análise da produção de significados sobre o sujeito em situação de refúgio. Busco refletir sobre a miríade de imagens acerca da figura do refugiado, produzida pela grande mídia brasileira no período entre 2013 e $2017^{6}$. Para que isso seja possível, recorro à abordagem com corpus, que faz uso de softwares e técnicas específicas para acessar e interpretar o extenso material compilado dos jornais online e portais de notícias mais acessados no país. Proponho dois eixos centrais para a análise: uma dimensão léxica, abordando o conjunto de termos mais utilizados em referência à categoria de refugiado, e uma dimensão gramatical, tratando dos processos de agência gramatical por meio dos verbos dos quais o refugiado é posto como sujeito e objeto. A partir deste esforço analítico, que reúne contribuições quantitativas e qualitativas, a proposta é refletir sobre o campo semântico do refúgio no Brasil e os espaços de habitação possível na mídia para quem se encontra na condição refugiada. O fio condutor da injustiça epistêmica acompanha as análises e torna possível a reflexão sobre como um empobrecimento e uma marginalização nos recursos coletivos hermenêuticos acompanham a vida dos refugiados, escapando dos espaços da

\footnotetext{
${ }^{6} \mathrm{O}$ período temporal da análise com corpus é distinto daquele da realização das entrevistas sobre o processo do refúgio por elegibilidade. Isso se dá, em grande medida, pelo fato de que a análise das práticas de representação midiática não está subsumida à tentativa de corroborar ou ampliar a compreensão sobre o conteúdo das entrevistas e sobre os processos aos quais estas fazem referência. Em outras palavras, o presente estudo sobre representação midiática foi desenvolvido de forma a ensejar uma discussão sobre injustiça epistêmica que não ficasse restrita ao campo das trocas testemunhais e que pudesse permitir, assim, reflexões mais amplas sobre a possibilidade de injustiças hermenêuticas que acompanham os sujeitos refugiados em diferentes esferas, para além da elegibilidade.
} 
elegibilidade e determinando a imagem do refúgio para além dos processos oficiais de determinação do status. 


\section{2}

\section{A injustiça epistêmica e o refúgio}

\section{Resumo}

Este capítulo busca refletir sobre um tipo essencialmente epistêmico de injustiça, intimamente relacionado a duas práticas diárias básicas: transmitir conhecimento ao outro por meio do testemunho, da narrativa individual, e fazer sentido das próprias experiências sociais. Tais práticas podem refletir duas formas particulares de injustiça epistêmica: a injustiça testemunhal e a injustiça hermenêutica. Proponho, assim, não somente um esforço de análise a partir da perspectiva individual da narrativa e do encontro com o outro, mas também uma reflexão que leve em conta os esquemas de inteligibilidade que compõem a estrutura sóciopolítica na qual o encontro acontece. O objetivo deste capítulo é expor a perspectiva teórico-filosófica sobre a injustiça epistêmica, bem como algumas das principais críticas e discussões, sem desconsiderar a possibilidade de aplicação do debate ao campo do refúgio. Busco refletir, então, sobre como pensar a condição refugiada a partir de um quadro de injustiça epistêmica que aponta para a necessidade de estarmos atentos aos espaços de troca e inteligibilidade que atravessam o refúgio e a vida de determinados sujeitos.

Palavras-chave: Injustiça Epistêmica; Testemunho; Epistemologia; Refúgio.

\section{1 Introdução}

Os fundamentos do refúgio se desenvolveram de maneira ancorada em um regime internacional de Direitos Humanos que surgiu após a Segunda Guerra Mundial com o objetivo de assegurar direitos essenciais à humanidade. Neste contexto, não é possível desprezar a influência da filosofia cosmopolita kantiana que ajuda a estabelecer a hospitalidade como direito essencial, ressaltando a justiça como a necessidade de conformação a leis externas - como, por exemplo, o direito a ser tratado como amigo em qualquer lugar do mundo (Jubilut, 2007). Embora o refúgio possa ser pensado como uma questão de produção de justiça através do fortalecimento da proteção internacional àqueles que tiveram que fugir de seus países de origem ou residência habitual, o foco desta tese não é uma reflexão sobre o estatuto do refúgio à luz da filosofia do direito. Ao invés disso, a exploração que procuro fazer aqui está voltada à possível dimensão da injustiça no âmbito das 
atividades epistêmicas que atravessam o campo do refúgio e ajudam a produzir sujeitos refugiados.

Como é possível, então, pensar o refúgio a partir da ótica de uma injustiça essencialmente epistêmica? O olhar da pesquisa recai aqui sobre a produção epistêmica de sujeitos pelo sistema, tanto na esfera do processo de elegibilidade, com uma dimensão testemunhal da injustiça, quanto na esfera da representação midiática, com uma dimensão hermenêutica da injustiça. A partir disso, surge como relevante a reflexão sobre como determinadas práticas em espaços de troca testemunhal podem produzir uma injustiça epistêmica, afetando a vida de solicitantes e refugiados.

Com tais preocupações em mente, proponho a abertura de um caminho de pesquisa com a potencialidade de explorar as questões de injustiça epistêmica nas práticas diárias que constituem o universo do refúgio. É preciso, assim, suspeitar da categoria do refugiado per se e investigar os processos de produção de significados e sua articulação com o acesso a direitos, considerando suas implicações práticas na vida dos sujeitos refugiados. Para tanto, farei uso do conceito filosófico de injustiça epistêmica nos termos delimitados por Miranda Fricker (2007) em seu livro Epistemic Injustice: Power \& the Ethics of Knowing, explorando também o campo de debates em torno do tema. Em sua obra, a autora propõe a existência de um tipo essencialmente epistêmico de injustiça, caracterizado por um "mal feito a alguém especificamente em sua capacidade como um sujeito do conhecimento" (idem, p.1). A injustiça epistêmica pode assumir duas formas: testemunhal e hermenêutica. A primeira é definida como algo que "ocorre quando um preconceito leva um ouvinte a conceder um nível esvaziado de credibilidade para a palavra daquele que narra", enquanto a segunda “ocorre em um estágio anterior, quando um gap nos recursos interpretativos coletivos coloca alguém em desvantagem quando se trata de fazer sentido de suas experiências sociais" (idem).

A fim de pensar o refúgio à luz da injustiça epistêmica, buscarei partir de um conceito central tanto para a caracterização deste tipo de injustiça por Fricker (2007) quanto para a produção do sujeito refugiado especificamente pelo processo de determinação do status: a credibilidade. Nesse sentido, procuro expor o papel crucial atribuído à análise de credibilidade a fim de produzir a categoria do refugiado, através da concessão do status, e como alguns de seus aspectos dialogam com as preocupações sobre a possibilidade de uma injustiça epistêmica que recai 
sobre aqueles que buscam refúgio. Neste cenário, veremos emergir a relevância da dimensão testemunhal e a atuação de preconceitos e estereótipos nos julgamentos de credibilidade que constituem o universo do refúgio, no Brasil e no mundo.

Mesmo diante deste quadro de enfoque sobre os espaços de troca testemunhal, também será possível analisar a implicação do viés hermenêutico da injustiça epistêmica, especialmente no que diz respeito aos estilos narrativos empregados pelos solicitantes de refúgio e sua ausência na produção de significados sobre - e a partir de - sua própria experiência. Esta última questão, em especial, abre caminho para a reflexão acerca de como a injustiça hermenêutica, embora se manifeste em trocas testemunhais, pode estar mais evidente no cenário amplo de marginalização hermenêutica de determinados membros de um grupo social. Assim, ainda que a análise parta da dimensão testemunhal da injustiça epistêmica e do conceito central de credibilidade, também procuro inserir um cenário estrutural mais amplo no qual as injustiças em relação aos refugiados podem se reproduzir, ressaltando seu caráter sistemático proveniente das desigualdades de participação no espaço de geração de significados sobre a experiência social do refúgio.

Como modo de estruturar e organizar a escrita deste capítulo inicial, a discussão irá partir do campo teórico-filosófico em torno do conceito de injustiça epistêmica. Inicio, assim, com a dimensão testemunhal deste tipo de injustiça e, em seguida, abordo seu viés hermenêutico, sem deixar de trazer para a análise algumas contribuições diversas sobre o tema. Nesse sentido, embora utilize como contribuição principal para a tese a perspectiva desenvolvida por Miranda Fricker (1999, 2003, 2006, 2007, 2010) em diversas produções, também procuro explorar críticas e questionamentos existentes no campo de debates como um todo. Ao tratar da injustiça testemunhal, buscarei ressaltar o papel importante exercido por uma "economia da credibilidade", bem como o quadro de preconceitos identitários e estereótipos que ajudam a produzir ataques diretos à autoridade epistêmica daquele que narra algo e à sua capacidade enquanto sujeito do conhecimento. No âmbito hermenêutico de uma injustiça epistêmica, procurarei inserir a discussão no contexto da desigualdade experimentada por sujeitos que pertencem a grupos socialmente marginalizados e que também acabam tornando-se hermeneuticamente marginalizados.

Tendo exposto e trabalhado criticamente os principais conceitos que irão orientar a análise nos próximos capítulos, proponho uma reflexão introdutória sobre 
como pensar o refúgio à luz de uma injustiça epistêmica. A parte final estará voltada, então, à tentativa de produzir articulações prévias entre algumas das principais práticas do refúgio, no Brasil e no mundo, e o quadro de manifestação de formas testemunhais e hermenêuticas de injustiça epistêmica. Tal questão, porém, será analisada detalhadamente ao longo da tese.

\section{2 \\ O relato de si e o encontro com o outro}

Em sua obra "Relatar a si mesmo. Crítica da violência ética", Judith Butler reflete criticamente sobre as dificuldades éticas do sujeito moderno, constantemente desafiado a engajar-se em práticas de narratividade. Em consonância com Nietzsche, a autora nos lembra sobre a importância do encontro com o outro no esforço de nos tornarmos seres autonarrativos, uma vez que "só começamos a contar uma história de nós mesmos frente a um 'tu' que nos pede que o façamos" (Butler, 2017, p.23). Diante do outro, do seu questionamento e de uma cena de interpelação, aquele que oferece um relato de si mesmo passa a estar implicado em uma relação com aquele que o interpela (e vice-versa). Os termos de um relato autonarrativo que permitem a inteligibilidade do diálogo entre o eu e o outro não seriam, porém, criados pelos próprios sujeitos, conforme nos diz Butler, mas teriam um caráter social mais amplo, estabelecendo normais sociais que apontam para um cenário de falta de liberdade em que as histórias são narradas. A fim de refletir sobre os limites da inteligibilidade deste encontro, a autora recorre a Foucault para mostrar que:

a questão da ética surge precisamente nos limites de nossos esquemas de inteligibilidade, lugar onde nos perguntamos o que significaria continuar um diálogo em que não se pode assumir nenhuma base comum, onde nos encontramos, por assim dizer, nos limites do que conhecemos, mas onde ainda nos é exigido dar e receber reconhecimento: há alguém que está ali para ser interpelado e cuja interpelação deve ser acolhida (Butler, 2017, p.34).

A partir de sua discussão, Butler nos leva a pensar uma questão que parece fundamental na análise sobre o refúgio como um problema ético-epistemológico: fora do espaço do inteligível, diante da natureza incomunicável ou de difícil tradução da experiência do refúgio, como lidar eticamente com a necessidade do reconhecimento do outro, do seu relato e do conhecimento que aporta? A utilização da obra de Butler aqui faz com que lembremos não só a importância de uma 
perspectiva voltada para os termos de um encontro entre o eu e o outro, mas também de uma dimensão estrutural relevante em processos de reconhecimento. $\mathrm{O}$ uso que a autora faz de Foucault levanta a questão central dos termos que possibilitam o reconhecimento, que estariam localizados não no quadro do encontro, mas fora dos sujeitos, em um regime de verdade. Nesse regime, as normas disponíveis orientam o reconhecimento de si, mas também o reconhecimento do outro, uma vez que "o regime de verdade fornece um quadro para a cena de reconhecimento, delineando quem será classificado como sujeito de reconhecimento e oferecendo normas disponíveis para o ato de reconhecimento" (Butler, 2017, p.35). Nesse sentido, ressalto que a reflexão apresentada aqui sobre uma dimensão individual do encontro, do relato testemunhal e narrativo entre sujeitos, não irá prescindir de uma discussão mais ampla sobre os termos estruturais que podem orientar a ocorrência da cena de interpelação e do processo de reconhecimento, análise esta que procuro desenvolver na seção seguinte sobre injustiça hermenêutica.

Por ora, gostaria de apresentar outra questão importante que utilizo para introduzir a discussão sobre um quadro de injustiça testemunhal e que guarda relação estreita com a dificuldade intrínseca a todo relato de si mesmo e, portanto, aos limites da inteligibilidade em uma cena de interpelação. Estou me referindo aqui à parcialidade de todo relato autonarrativo, à existência dos pontos cegos ou da opacidade que impede que o sujeito ofereça um relato completo, único, verdadeiro, sobre si mesmo. Sobre essa questão, Butler nos diz que podemos recontar várias vezes uma determinada história sobre nós mesmos, e que podemos fazê-lo de diversas maneiras, mas não poderíamos afirmar com certeza que apenas uma determinada narrativa sobre nós mesmos é a verdadeira. Em outras palavras, todo relato de si é parcial e aponta para a existência de algo que escapa à compreensão e à possibilidade narrativa do próprio sujeito. Ou seja: "há algo em mim e de mim do qual não posso dar um relato" (Butler, 2017, p.55).

Para Butler, então, o relato de si não é capaz de capturar por completo o sujeito da narrativa, marcando a existência de um excesso que aponta para o necessário fracasso de todo e qualquer projeto autonarrativo. A compreensão de tal fracasso surge como ponto fundamental para a cena de interpelação e o processo de reconhecimento do outro, uma vez que faz lembrar a necessidade da não produção de expectativa sobre um relato do sujeito que seja completamente satisfatório. Butler concebe a própria vida como "aquilo que excede qualquer relato que dela 
possamos dar" (Butler, 2017, p.61). Nesse sentido, não esperar uma resposta satisfatória do outro sobre ele mesmo significaria deixá-lo viver e, portanto, exercer a dimensão ética do reconhecimento. Para Butler, a postura ética a ser adotada em um processo de reconhecimento consistiria, assim, em jamais esperar que o outro seja completamente capturado por uma resposta à interpelação sobre sua identidade. Segundo a autora, então, a dimensão ética estaria necessariamente relacionada à apreensão dos limites epistêmicos do relato de si mesmo e do reconhecimento do outro. Neste quadro, seria preciso uma suspensão temporária do juízo para a possibilidade de apreender o outro, uma vez que "nos baseamos em juízos de culpa ou inocência para resumir a vida do outro, confundindo postura ética com aquele que julga" (Butler, 2017, p.63).

Distanciar-nos do julgamento e da pretensão da captura completa do outro implicaria, assim, abrir mão de um relato autobiográfico totalmente coerente, adotando, ao invés disso, a ideia de uma "verdade da pessoa", como nomeia Butler. O caminho para uma postura ética neste contexto passaria, necessariamente, por uma abertura à verdade não como uma história contínua (plausível, consistente, coerente), mas como algo que se tornaria mais claro precisamente nos momentos de interrupção e indefinição, isto é, "nas articulações enigmáticas que não se podem traduzir facilmente em forma narrativa" (Butler, 2017, p.86). Seria preciso ter em mente, então, o excesso que não pode ser capturado pelo esforço narrativo, aquilo que não pode ser relatado sobre si mesmo e, com isso, o necessário fracasso que, segundo Butler, constitui o projeto da narração de si. Para a autora, é necessário tropeçar neste fracasso para finalmente aproximar-se da postura ética no processo de reconhecimento. A partir dessa discussão filosófica, proposta pela autora, é possível identificar a importância não só das normas sociais externas à relação entre o eu e o outro e que influenciam as condições de possibilidade do reconhecimento, mas também das dificuldades intrínsecas aos sujeitos em seus esforços narrativos e a conseqüente demanda que gera em termos de uma postura ética do encontro.

A discussão proposta por Butler sobre práticas autonarrativas e processos de reconhecimento nos ajuda a iniciar uma reflexão sobre os limites da inteligibilidade no encontro entre o eu e o outro e suas implicações em termos de justiça e poder. Como nos diz a autora, uma compreensão da ética neste debate está intrinsecamente relacionada à apreensão dos limites epistêmicos que enquadram o encontro e que não podem ser encontrados apenas na dimensão individual da interação entre 
sujeitos, mas em um conjunto estrutural de normas sociais que ajudam a constituir as condições de possibilidade para o reconhecimento do outro. Neste início, porém, irei me deter sobre a dimensão testemunhal da cena de interpelação, trazendo para a discussão a perspectiva teórica proposta por Fricker, com a sua ênfase em um tipo essencialmente epistêmico de injustiça. Isso não significa, porém, deixar de lado a questão da ética, uma vez que a autora insere sua escrita na intersecção entre a ética e a epistemologia.

O projeto filosófico de Fricker passa, necessariamente, pela reflexão sobre a postura ética nas práticas epistêmicas, deixando claro seu objetivo de pensar a potencialidade de uma conduta epistêmica que possa ser concebida em termos mais racionais e justos. Para tanto, é necessário compreender já de início a percepção da autora sobre o que constitui uma injustiça, voltando nossa atenção à natureza do mal infligido. Assim, para Fricker, uma injustiça epistêmica estaria relacionada ao "mal causado a alguém em sua capacidade enquanto um sujeito de conhecimento e, assim, em uma capacidade essencial para o valor humano" (Fricker, 2007, p.5).

As questões éticas que Fricker busca discutir estão inseridas no contexto de práticas epistêmicas "socialmente situadas", no sentido de que os sujeitos envolvidos não são vistos de forma deslocada das relações sociais de poder que constituem suas interações uns com os outros. A concepção da autora de poder social considera o poder como "uma capacidade da parte de agentes sociais (indivíduos, grupos ou instituições) exercida em relação a outros agentes sociais" (idem, p.10). Embora de início esta concepção possa ser vista apenas como poder individual, de agentes específicos, Fricker também afirma a dimensão estrutural do poder, trazendo a contribuição de Foucault sobre as formas estruturais em que o poder opera. Segundo Fricker, então, há uma dimensão essencialmente estrutural do poder que está relacionada ao seu caráter socialmente situado, isto é: a compreensão dos modos de funcionamento do poder passa pela análise de um contexto social fundamental. Assim, "qualquer operação de poder é dependente do contexto de um mundo social em funcionamento - instituições, significados e expectativas compartilhadas, e assim por diante" (idem, p.12). A partir disso, a

\footnotetext{
${ }^{7} \mathrm{O}$ termo "socialmente situado" é utilizado pela perspectiva feminista proposta por Donna Haraway em seu artigo Situated Knowledges: The Science Question in Feminism and the Privilege of Partial Perspective (1988).
} 
autora propõe uma definição para sua concepção de poder social, que pode ser entendido como: "uma capacidade, situada prática e socialmente, de controlar as ações dos outros, que pode ser exercida (passiva ou ativamente) por agentes sociais particulares ou, alternativamente, pode operar de maneira puramente estrutural" (idem).

Tendo discutido a concepção de Fricker de poder social, cabe trazer ao debate outro conceito da autora que se apresenta como fundamental para entendermos sua perspectiva acerca da injustiça epistêmica: a dimensão identitária do poder ou um tipo de poder que podemos chamar de identitário. Este tipo de poder requer, segundo Fricker, que estejam em operação concepções imaginadas (e compartilhadas) de uma identidade social. Nesta perspectiva, o modus operandi do poder exercido com base em identidades está localizado no âmbito da imaginação social coletiva e, assim, na existência de estereótipos e preconceitos. A discussão da autora sobre esta dimensão do poder se dá pela sua importância como uma parte intrínseca ao mecanismo da troca testemunhal, uma vez que, segundo Fricker, o uso de estereótipos sociais acompanha as avaliações de credibilidade que têm lugar na cena de interpelação. Tendo isto em mente, torna-se mais fácil compreender o impacto que o poder com base em identidades (e, assim, os estereótipos) exerce nas relações discursivas e epistêmicas e a potencialidade de produção de uma injustiça de tipo testemunhal.

A noção de credibilidade também exerce papel central na análise filosófica de Fricker sobre a injustiça epistêmica, especialmente em sua dimensão testemunhal, considerando que neste tipo de troca e interação aquele que interpela deve atribuir algum grau de credibilidade em relação ao sujeito que narra ou responde aos questionamentos (Fricker, 2007). Embora a autora reconheça a possibilidade tanto de um excesso de credibilidade, quanto de um déficit, sua ênfase recai sobre o último caso, tendo em vista suas implicações fundamentais em termos da perpetração de injustiças. Nesse sentido, a autora afirma ser o conceito de injustiça testemunhal uma forma de déficit de credibilidade em que alguém é injustiçado especificamente em sua capacidade como um sujeito do conhecimento.

Fricker reconhece que um déficit de credibilidade pode ocorrer em função do que a autora chama de "erros inocentes", tendo em vista a falibilidade do julgamento humano. Porém, seu interesse maior está em analisar os casos de déficit de credibilidade que ocorrem devido à existência de preconceitos identitários, o que 
faz com que a injustiça testemunhal esteja conectada com outros tipos de injustiça, assumindo um caráter sistemático. Em outras palavras: "quando um preconceito gera uma injustiça testemunhal, essa injustiça está sistematicamente conectada com outros tipos de injustiça existente ou potencial" (idem, p.27). Segundo a autora, o caso central de seu debate passa a ser, então, a injustiça testemunhal sistemática, uma vez que esta revelaria como a injustiça epistêmica está inserida em um padrão mais amplo de justiça social.

Cabe ressaltar aqui que a ênfase da autora sobre déficits de credibilidade acabou por abrir espaço para a crítica desenvolvida por José Medina (2011) acerca da importância dos excessos de credibilidade que, segundo ele, emergem como uma forma de privilégio epistêmico ${ }^{8}$ imerecido que possui papel crucial em um quadro de injustiça epistêmica. Medina reforça que os julgamentos de credibilidade possuem efeitos interativos sobre os sujeitos, não podendo ser vistos de maneira isolada, uma vez que um sujeito é julgado mais, menos ou igualmente crível em relação a outros. Nesse sentido, a atribuição de excessos de credibilidade revela uma confiança epistêmica desproporcional que possui efeitos sobre vários sujeitos, não somente aquele a quem foi dado um nível excessivo de credibilidade. $\mathrm{O}$ autor critica, assim, a desatenção de Fricker sobre o papel que excessos de credibilidade podem desempenhar na produção de uma injustiça testemunhal, ressaltando a qualidade comparativa dos julgamentos sobre o caráter crível de um sujeito. Considero apropriada a crítica desenvolvida por Medina (2011), inclusive sua perspectiva de que a correlação entre déficits e excessos de credibilidade na produção de injustiças é uma questão empírica, não sendo possível afirmar a priori sua inexistência, como o faz Fricker $(2007,2008)$. As análises realizadas nos próximos capítulos contribuem para este debate ao demonstrarem a relevância da atribuição de excessos de credibilidade no reforço de uma posição epistêmica privilegiada que está diretamente ligada aos déficits de credibilidade que podem ser atribuídos aos solicitantes de refúgio.

\footnotetext{
${ }^{8}$ Medina (2011) não define privilégio epistêmico, mas utiliza o termo como sinônimo de excessos (não-merecidos) de credibilidade. Já em Hiebert (2015) encontramos a definição de privilégio epistêmico como sendo a credibilidade dada aos que desfrutam de uma posição de poder - a atribuição de credibilidade ocorre, assim, exclusivamente em função de seu status elevado na sociedade. Cabe ressaltar, ainda, que apesar do uso do termo em artigo de Fricker (1999), sua definição não é estabelecida no texto e sua utilização é feita de maneira indiscriminada. Utilizo o termo privilégio epistêmico na tese de acordo com a perspectiva desenvolvida por Medina (2011), isto é, como um excesso de credibilidade não-merecido.
} 
De volta ao quadro geral estabelecido por Fricker a respeito de uma injustiça testemunhal, é preciso ter em mente que sua noção de preconceito está diretamente relacionada à atuação de estereótipos, vistos como amplas associações entre um grupo e um atributo, produzindo um "compromisso cognitivo com alguma generalização empírica sobre determinado grupo social ('mulheres como seres intuitivos')" (Fricker, 2007, p.31). O estereótipo conectado com um tipo particular de preconceito identitário acaba gerando, então, generalizações empíricas não confiáveis sobre o grupo social em questão. Aqui, novamente, a autora não está interessada no que chama de um erro inocente que poderia acompanhar determinada generalização, mas sim nos casos em que há um pré-julgamento realizado sem consideração pelas evidências e que, portanto, poderia ser concebido como "epistemicamente culpado" (idem, p.33). Nesta perspectiva, ser culpado significa ser resistente às evidências de modo a tornar-se irracional, o que envolve a atuação de um tipo de preconceito identitário que caracteriza a injustiça testemunhal sistemática - o foco do trabalho de Fricker e, também, dessa investigação. Cabe ressaltar, ainda, que é possível a internalização de estereótipos mesmo em casos nos quais os sujeitos possuem crenças conflitantes com a imagem negativa do preconceito, o que poderia gerar formas mais sutis de injustiça testemunhal.

A questão da culpabilidade é abordada melhor por Riggs (2012) em sua crítica à noção de Fricker acerca da natureza do mal infligido em casos de injustiça testemunhal. Conforme argumenta Riggs, a culpa desempenha um papel relevante na abordagem teórica proposta por Fricker, embora a autora oscile sobre a relevância de ser ou não culpado de infligir um mal a alguém como algo necessário para a perpetração de uma injustiça epistêmica testemunhal. Na tentativa de preencher o que o autor compreende como uma lacuna no desenvolvimento da questão da culpabilidade, Riggs busca definir por qual motivo um sujeito pode ser considerado culpado de cometer uma injustiça testemunhal. A pergunta que ele propõe é: o que alguém faz, exatamente, para que possa ser considerado culpado? A resposta do autor está centrada na questão da negligência, isto é, quando um sujeito deixa de agir conforme estaria moralmente obrigado a agir. Considerando a existência de preconceitos e estereótipos nas trocas testemunhais, um sujeito estaria moralmente obrigado a negar os efeitos de uma postura preconceituosa ao realizar julgamentos de credibilidade. Se isso não é feito, o mal ou a injustiça resultante deriva da negligência do sujeito. Para que a falência em agir constitua culpa, há 
duas condições epistêmicas que precisam estar presentes: primeiro, deve ser razoável esperar que a parte negligente saiba que ela estava moralmente obrigada a fazer algo que não fez e, segundo, deve ser razoável esperar que o sujeito reconheça que sua inação pode levar a um determinado mal (Riggs, 2012).

Para além da discussão sobre culpabilidade, Fricker vai delineando em sua obra filosófica um quadro de injustiça testemunhal que constitui uma injustiça ética vista como não-trivial, profundamente capaz de produzir danos sobre a vida do sujeito injustiçado, e conectada sistematicamente com outras formas de injustiça presentes na sociedade. $\mathrm{O}$ caráter epistêmico da injustiça causada é tratado pela autora sob o ponto de vista da distorção dos julgamentos de credibilidade, o que faz com que um determinado conhecimento não seja transmitido ao interlocutor. $\mathrm{O}$ preconceito representa, segundo Fricker, um obstáculo à verdade, seja porque faz com que aquele que escuta perca uma verdade em particular, seja porque cria indiretamente bloqueios à circulação de idéias. Poderia haver, assim, um obstáculo à produção de conhecimento na esfera do domínio público, fazendo com que determinadas informações simplesmente não estejam ao alcance coletivo devido à injustiça epistêmica em cenas de interpelação. A autora tem o cuidado, contudo, de ressaltar também a dimensão ética da injustiça epistêmica, uma vez que ser injustiçado enquanto sujeito do conhecimento afeta algo essencial para a valoração humana. Conforme nos diz Fricker, em consonância com a história da filosofia, a capacidade de transmitir conhecimento ao outro é especialmente relevante ao ser humano, já que está relacionada à capacidade de ser racional. Em outras palavras, a racionalidade é algo que concede à humanidade seu valor e caráter distinto e, dessa forma, a vida epistêmica constitui um centro de importância para os seres humanos, fazendo com que o sujeito injustiçado enquanto sujeito do conhecimento também sofra um dano moral.

Alguns autores partem da perspectiva teórica proposta por Fricker (2007) e buscam expandi-la, trazendo, por exemplo, alguns casos que consideram merecer o nome de "injustiça testemunhal" ainda que sejam distintos dos casos centrais levantados pela autora. Para Marsh (2011), seria possível identificar a produção de formas de injustiça testemunhal contra aquele que recebe ou escuta o testemunho do sujeito que fala. Como exemplo, o autor traz um cenário em que um professor compartilha conteúdo de maneira extremamente simplificada por avaliar uma suposta incompetência por parte de seus alunos, que poderiam pertencer a algum 
grupo minoritário. Tendo em vista a atuação de preconceitos e estereótipos, a postura do professor faz com que parte significativa do seu conhecimento não seja transmitida e seus alunos sejam tratados como inferiores.

O mesmo autor traz, ainda, uma segunda forma que considera um caso de produção de injustiça testemunhal e que também afeta àquele que recebe ou escuta o testemunho, porém neste cenário haveria mais - e não menos - compartilhamento de informações. Seria o caso, por exemplo, de um casal que fala sobre assuntos íntimos ou sobre terceiros em frente aos seus empregados domésticos, que receberiam mais informações do que seria do seu interesse saber (Marsh, 2011). Neste contexto, e segundo o autor, o mal causado guarda relação com tornar estes ouvintes invisíveis, como se fossem parte da mobília da casa ou animais de estimação em frente dos quais podemos falar livremente e sem constrangimentos.

Embora os casos levantados por Marsh sejam interessantes para análise das práticas epistêmicas em trocas testemunhais, considero que extrapolam a definição de injustiça testemunhal ao ponto de tornar o conceito amplo demais para ser analiticamente útil, especialmente no que diz respeito à "economia da credibilidade", que possui papel central na teoria de Fricker (2007) e neste trabalho. Nesse sentido, parece necessário manter o caráter original que compõe o cerne deste tipo de injustiça e que está diretamente relacionado a um julgamento de credibilidade distorcido do sujeito que fala e de seu testemunho. Tendo isso em mente, uma expansão importante da abordagem proposta por Fricker, mantendo seu caráter original, é aquela desenvolvida por Gloria Origgi (2012), que indica a possibilidade de ampliar a análise da injustiça testemunhal ao indicar outros mecanismos que podem enviesar os julgamentos de credibilidade, para além dos preconceitos e estereótipos. Segundo Origgi, estes últimos seriam apenas um dos casos em que pode existir uma distorção nas práticas epistêmicas de atribuir credibilidade aos sujeitos e seus testemunhos. Em sua análise, a autora propõe outros mecanismos ${ }^{9}$ que poderiam enviesar o modo como confiamos naquilo que alguém nos diz, produzindo condições de possibilidade para a operação de uma

\footnotetext{
${ }^{9}$ Origgi (2012, p.228) propõe a existência de sete mecanismos: inferência sobre a confiabilidade do sujeito; inferência sobre a confiabilidade do conteúdo; normas sociais internalizadas no modo de lidar com a autoridade; palpites socialmente distribuídos sobre a reputação; sinais robustos; reações emocionais; e compromissos morais. Para uma compreensão maior dos significados de tais mecanismos, bem como dos aspectos cognitivos, culturais e morais que os sustentam, é preciso retomar o artigo da autora na íntegra - o que está além do escopo deste capítulo.
} 
injustiça testemunhal. Alguns deles, como inferência sobre a confiabilidade do sujeito e do conteúdo e reações emocionais, são levantados nas análises dos próximos capítulos, de modo a complementar o quadro de distorção das análises de credibilidade em relação aos refugiados e solicitantes de refúgio.

Cabe ressaltar, ainda, a existência de outro esforço de expansão da abordagem proposta por Fricker (2007), a partir da perspectiva de que nem todo tipo de injustiça epistêmica envolve a habilidade de testemunhar algo ou fazer afirmações. Chris Hookway (2010) sustenta que há mais tipos de injustiça epistêmica do que aqueles levantados por Fricker e que não necessariamente envolvem a existência de obstáculos à transmissão de conhecimento (testemunhal) ou a falta de recursos hermenêuticos coletivos (interpretação da experiência social). O autor traz, assim, possibilidades de produção de injustiça epistêmica que estariam relacionadas à participação em debates e deliberações. Teríamos como exemplo o caso de um professor que, devido a preconceitos, tende a considerar irrelevantes questões levantadas por determinados alunos, falhando em tratá-los como sujeitos que teriam algo a contribuir para determinada discussão. Fricker (2010) busca responder à crítica levantada por Hookway em artigo no qual afirma que sua proposta sempre fora de que a injustiça epistêmica constituísse uma categoria guarda-chuva, isto é, que fosse capaz de abrigar novas elaborações. A autora também afirma que a dimensão testemunhal e a hermenêutica seriam tipos básicos de injustiça epistêmica a partir dos quais outros poderiam surgir. Por fim, segundo Fricker, seria desejável manter a clareza do conceito de injustiça testemunhal, preservando sua proposta e encontrando novos rótulos para diferenciar os outros tipos discursivos da injustiça epistêmica que Hookway sugere.

Apesar da sugestão de que seria possível diferenciar outros tipos discursivos de injustiça epistêmica sob novo rótulo, que não aquele de injustiça testemunhal propriamente, Fricker (2010) acrescenta que ainda compreende o tipo discursivo levantado por Hookway como estando relacionado à dimensão testemunhal. Assim, para a autora, embora o exemplo do professor que recusa a relevância da participação epistêmica do aluno não seja especificamente uma questão testemunhal, ainda permaneceria um déficit de credibilidade devido a preconceitos. Fricker reconhece que poderia estar ampliando em demasiado a noção de testemunho e de credibilidade, uma vez que não seria, por exemplo, uma questão de esvaziar credibilidade, mas sim de esvaziar a estima da capacidade epistêmica 
de levantar questões relevantes. Segundo ela, porém, isto seria refinar demais a categorização do fenômeno, o que poderia impedir a exploração do conceito de injustiça epistêmica como sendo tanto internamente composto por certa diversidade, quanto estruturado de forma minimamente coerente. Nesse sentido, para Fricker, seria necessário agora investigar, juntamente ao esforço de Hookway (2010), a diversidade interna da categoria ampla de injustiça testemunhal.

Tendo apontado alguns debates travados no campo da expansão da abordagem de injustiça testemunhal, retorno agora a algumas percepções importantes de Fricker (2007) a respeito do que chama de economia da credibilidade. Explorando os julgamentos de credibilidade para fins de compreensão da injustiça testemunhal, a autora traz a idéia de que esta avaliação por parte daquele que escuta é realizada em termos de sua percepção do sujeito que narra como alguém mais ou menos confiável em dado cenário. Nesse sentido, o testemunho é percebido como uma questão de julgamento que envolve a noção de confiança - tida aqui não somente como confiança epistêmica (Origgi, 2004) ${ }^{10}$, mas também como confiança ética, porque a primeira dependeria de um tipo moral de confiança, caracterizado como sinceridade. A atitude de confiança, então, não emerge apenas de uma postura intelectual, racional, mas também de uma emoção: do sentimento de confiança. Assim, segundo Fricker, julgar a credibilidade de alguém envolveria apresentar (ou não) um sentimento de confiança em relação à sinceridade daquilo que é narrado, o que envolve necessariamente uma emoção no que concerne a percepções do outro enquanto um sujeito confiável ou enquanto alguém em quem é possível confiar em determinada cena de interpelação. Apresentar um sentimento de confiança também envolveria um tipo de engajamento emocional baseado na empatia, uma vez que sem isso aquele que julga a credibilidade não conseguiria apreender a performance do outro de forma apropriada.

Fricker traz a avaliação de credibilidade para o âmbito do subjetivo, das emoções e dos sentimentos, afastando uma dimensão puramente racional do julgamento daquilo ou de quem é considerado crível. Este ponto é fundamental para a compreensão da injustiça testemunhal, uma vez que abre espaço para o

\footnotetext{
${ }^{10}$ Origgi (2004) nos traz a confiança como uma noção epistemológica, ressaltando que, para além das questões morais, $\mathrm{o}$ ato de confiar em alguém está também diretamente relacionado ao julgamento da competência do sujeito.
} 
entendimento dos estereótipos em atuação, os quais se baseiam, conforme vimos, em imagens preconceituosas que se tornam resistentes a evidências, aproximandose do âmbito do irracional. Sem um exercício crítico consciente, que consistiria em rever crenças internalizadas sobre preconceitos identitários, há a reprodução de uma imagem distorcida do sujeito que narra, fazendo com que seu interlocutor seja incapaz de perceber o outro de maneira crível (Fricker, 2007). Dessa forma, a influência de estereótipos em uma troca testemunhal faz com que haja uma operação de poder identitário na relação entre aquele que escuta e aquele que narra. A fim de lançar luz sobre tal perspectiva, a autora exemplifica a partir do caso de negros e mulheres enquanto tipos sociais, isto é: a concepção desses sujeitos a partir de idéias sociais pré-determinadas faz com que haja uma distorção no julgamento de sua credibilidade e "essa operação de poder identitário controla quem pode transmitir conhecimento para quem e, assim, quem pode ganhar conhecimento de quem" (Fricker, 2007, p.90).

É preciso considerar, ainda, o processo de silenciamento dos sujeitos e grupos sociais que ocorre através da operação de formas de injustiça testemunhal. Fricker nos diz que há uma exclusão fundamental que marca um lugar-comum nesta injustiça: “aqueles grupos sociais que estão sujeitos ao preconceito identitário e, assim, ao déficit injusto de credibilidade, também não serão pedidos a compartilhar seus pensamentos, julgamentos e opiniões" (idem, p.130). Isso seria uma forma de esvaziar a própria troca testemunhal, tornando-a irrelevante ao ponto de impedir que uma determinada narrativa seja solicitada. Em outras palavras, o sujeito ou grupo é silenciado por um preconceito identitário que afeta negativamente sua credibilidade de forma anterior a qualquer encontro ou troca, impedindo este espaço de interação ao torná-lo irrelevante. Nesse sentido, esta forma anterior de injustiça testemunhal funciona como um mecanismo que silencia o outro, especialmente quando este outro faz parte de um grupo social oprimido e que, assim, torna-se privado da oportunidade de contribuir para o conhecimento coletivo com seu ponto de vista (Fricker, 2007).

Os sujeitos podem ser silenciados de maneira antecipada, então, ao serem excluídos de participarem de uma troca testemunhal, indicando como determinadas pessoas não são consideradas como sujeitos de informação e experimentam uma condição de opressão evidenciada pelo silêncio (Bailey, 2018). O trabalho desenvolvido por Dotson (2011) sobre violência epistêmica contribui para esta 
discussão ao identificar duas práticas específicas de silenciamento: testimonial quieting e testimonial smothering ${ }^{11}$. A primeira delas ocorre quando uma audiência falha em reconhecer o sujeito do discurso como um sujeito do conhecimento cuja narrativa ou testemunho valha a pena escutar. Conforme nos diz Bailey (2018) sobre a prática identificada por Dotson (2011), neste cenário, o déficit de credibilidade é tão severo que é como se o sujeito nem tivesse testemunhado nada. Já a segunda prática de silenciamento ocorre quando há uma tentativa de autosilenciamento, uma espécie de asfixia em que o próprio sujeito busca adequar o conteúdo da sua fala à competência testemunhal ${ }^{12}$ da audiência. Apesar das diferenças entre as práticas de silenciamento mencionadas aqui, é importante tratar o silêncio como uma condição de opressão que pode ser saturada com a raiva, como nos diz Bailey (2018). E esta emoção, segundo a autora, "sinaliza que estamos em uma situação injusta, cruel, perigosa ou que causa danos" (idem, p.110).

Tais práticas de silenciamento podem contribuir para a objetificação dos sujeitos. Isso ocorre porque há uma exclusão no que concerne à comunidade de informantes, isto é, dos sujeitos capazes de participar na produção e compartilhamento de conhecimento. Fricker diferencia aqui entre a figura do informante (sujeito) e a figura da fonte de informação (objeto). Este último acaba sendo usado apenas como objeto de conhecimento, uma vez que outros sujeitos podem usá-lo como uma fonte de informação, mas ele próprio não participa ativamente como ator epistêmico. O silenciamento é uma forma de comunicar ao sujeito que seu testemunho não merece ser escutado e, assim, negar-lhe o direito à participação social (Bailey, 2018). Exclui-se, com isso, a potencialidade de uma participação ativa no exercício coletivo de produção e compartilhamento do conhecimento, relegando alguém ou um grupo ao lugar da passividade e da objetificação epistêmica. Haveria nesse cenário, segundo Fricker, uma negativa importante da subjetividade que acaba produzindo uma des-humanização do outro. $\mathrm{Na}$ injustiça testemunhal teríamos, então, um processo de esvaziamento do status

\footnotetext{
${ }^{11}$ Tendo em vista a dificuldade de uma boa tradução dos termos cunhados por Dotson (2011), preferi mantê-los no original. Em caso de necessidade para fins de compreensão, poderíamos traduzi-los, respectivamente, como: aquietamento testemunhal e asfixia testemunhal.

${ }^{12} \mathrm{O}$ termo "competência testemunhal" é utilizado por Dotson (2011) para fazer referência à avaliação positiva do sujeito que fala em relação à habilidade da audiência em achar inteligível determinado testemunho.
} 
de alguém enquanto sujeito de conhecimento, relegando-o à posição de mero objeto epistêmico.

A discussão proposta por Fricker traz para o centro da análise a importância de uma consciência crítica reflexiva sobre o lugar social dos sujeitos nas interações. Isso se dá devido ao fato de que, segundo a autora, nas trocas testemunhais não há neutralidade possível - "todos possuem um gênero, todos possuem uma raça" (idem, p.91). Assim, sem um esforço daquele que interpela em refletir criticamente sobre sua própria posição social e a influência que pode exercer em um julgamento de credibilidade, torna-se possível a operação de preconceitos e a produção de uma injustiça testemunhal na cena de interpelação. Este esforço de diminuir o impacto do preconceito nos julgamentos de credibilidade ajudaria, então, a alcançar interações mais justas e verdadeiras, uma vez que a operação de estereótipos negativos dificulta uma aproximação com a verdade que o sujeito busca transmitir e com uma interpelação que não seja ferramenta de (re)produção de injustiças. É, assim, nesse sentido, que a autora considera que uma postura justa na relação testemunhal entre o eu e o outro é uma questão tanto de uma virtude intelectual quanto de uma virtude ética: ambas, porém, baseadas na motivação de diminuir o preconceito nos julgamentos de credibilidade. Torna-se evidente aqui, uma vez mais, a manutenção do compromisso da autora com uma abordagem que leve em consideração não somente o aspecto epistêmico das questões de justiça e poder, mas também ético.

Tanto Fricker (2003, 2007), quanto os outros autores já abordados aqui (Hookway, 2010; Marsh, 2011) compartilham uma perspectiva similar em relação à forma de combater a injustiça epistêmica, a qual está ligada ao desenvolvimento de uma virtude reflexiva anti-preconceituosa que seja capaz de enfrentar as disfunções epistêmicas relacionadas ao mal que decorre deste tipo de injustiça. Um autor que se distancia desta perspectiva é Kwong (2015) ao afirmar que não seria necessário desenvolver uma virtude sui generis para combater a injustiça epistêmica, mas sim uma virtude intelectual relacionada à qualidade de ser "mente aberta"13. Para tanto, o autor propõe seguir a perspectiva de Riggs (2010), não postulando nenhuma virtude específica contra os tipos de injustiça epistêmica, mas

\footnotetext{
${ }^{13}$ Kwong (2015) define a qualidade em ser "mente aberta" como uma virtude intelectual relacionada ao caráter de um sujeito, uma vez que sua aquisição, cultivo e emprego são aspectos comportamentais pelos quais uma pessoa pode ser responsabilizada.
} 
apenas a manutenção de uma postura atenta às próprias fraquezas cognitivas, monitorando a si mesmo contra tais fraquezas, desenvolvendo a consciência dos preconceitos que afetam nossos julgamentos de credibilidade e nossas atribuições de confiança, e tendo em mente a possibilidade de pontos de vista alternativos.

Para Kwong (2015), então, seria preciso desenvolver uma postura virtuosa contra preconceitos, a qual pode ser concebida sob a disposição geral em ser "mente aberta”. Cabe ressaltar que esta perspectiva é fruto de um desenvolvimento teórico através do qual o autor compreende, a partir de sua leitura de Riggs (2010) e Baehr (2011), a própria injustiça epistêmica como ocorrendo em função de uma falência em ser "mente aberta". A partir disso, Kwong argumenta que não seria necessária uma virtude intitulada "justiça epistêmica", mas apenas a virtude intelectual que responda a tal falência, responsável por produzir quadros de injustiça epistêmica ${ }^{14}$.

Linda Alcoff (2010) busca se inserir no debate acerca das formas de combater a injustiça testemunhal apontando a necessidade de criação de mecanismos para neutralizar o impacto dos preconceitos em julgamentos de credibilidade - através da correção de déficits, da manutenção da neutralidade quando há uma tendência ao ceticismo ou do reconhecimento dos desafios que alguns sujeitos enfrentam na articulação de seus testemunhos. Ao mesmo tempo, porém, a autora enfatiza que todos esses mecanismos seriam práticas derivadas da vontade dos indivíduos ou, em outras palavras, práticas que devem ser cultivadas de maneira consciente.

Alcoff levanta diretamente a pergunta à Fricker: "se o preconceito opera via imaginário coletivo, como ela [Fricker] sugere, através de imagens associadas e conotações relativamente inconscientes, pode haver um antídoto bem-sucedido que opere totalmente como uma prática consciente?”(Alcoff, 2010, p.132). Para Alcoff, considerando que preconceitos podem atuar mesmo contra valores e compromissos que os sujeitos sustentam conscientemente, desenvolver uma abordagem virtuosa que opere apenas na esfera consciente das vontades humanas é um antídoto parcial contra a injustiça epistêmica. Mais do que isso, seria preciso explorar outros mecanismos para retificar este quadro, como reformas educacionais, projetos sérios

\footnotetext{
${ }^{14}$ Kwong (2015) busca complementar sua visão ao afirmar, sem maiores detalhes, que a virtude em ser "mente aberta" não seria capaz de combater, sozinha, um quadro de injustiça epistêmica. Assim, segundo ele, seria importante cultivar uma série de virtudes auxiliares, como perseverança, humildade, coragem intelectual, entre outras. $\mathrm{O}$ autor não desenvolve, porém, suas concepções acerca das virtudes mencionadas.
} 
de ação afirmativa, e currículos escolares aptos a corrigir preconceitos construídos por leituras históricas enviesadas (Alcoff, 2010).

Em resposta à crítica levantada por Alcoff, Fricker (2010) afirma que não considera ser tarefa fácil a neutralização dos preconceitos em nossos julgamentos de credibilidade, mas que sua ênfase sobre uma virtude reflexiva como modo de auto-regulação encontra apoio em estudos da psicologia social. Assim, segundo ela, a literatura empírica neste campo demonstra que uma reflexão crítica por parte dos sujeitos pode ajudá-los em seu próprio monitoramento contra uma postura preconceituosa. Embora a autora justifique sua abordagem a partir de alguns estudos sobre o desenvolvimento de virtudes reflexivas, ela também afirma que não propõe em sua obra uma auto-regulação como única forma de combate à injustiça epistêmica, mas também ressalta a importância da produção de mecanismos estruturais. Fricker não desenvolve, porém, como podemos pensar em formas estruturais de combate à injustiça epistêmica, mas retorna ao seu ponto sobre a importância de uma postura crítica reflexiva no próprio esforço inicial em criar mecanismos estruturais. Assim, segundo a autora, "as iniciativas para encontrar modos de neutralizar o impacto do preconceito em nossos julgamentos devem ser auto-reflexivas em primeiro lugar" (Fricker, 2010, p.166).

Embora a perspectiva desenvolvida por Fricker busque enfatizar o papel central de uma postura reflexiva e crítica voltada a combater o preconceito em nossas interações testemunhais básicas e diárias, permanece fundamental levar em consideração a necessidade de produzir mecanismos estruturais que não dependam exclusivamente de um auto-monitoramento dos sujeitos. Conforme nos diz Anderson (2012), não devemos ver mecanismos estruturais como competidores em relação às soluções baseadas em virtudes individuais. Os próprios mecanismos estruturais permitiriam, segundo a autora, um bom funcionamento das virtudes ao fornecer condições mais favoráveis a sua atuação. Como exemplo, Anderson levanta a questão dos processos de contratação em empresas: mecanismos estruturais para prevenir a discriminação incluem requisitos institucionais para que não só a contratação de pessoas, mas também a sua demissão e promoção levem em conta medidas objetivas, e não avaliações subjetivas. Assim, nesse caso, os mecanismos estruturais são desenhados para prevenir que possíveis preconceitos interfiram nos processos e para facilitar o exercício consciente do monitoramento individual contra julgamentos injustos. Da mesma forma, seria possível 
desenvolver mecanismos estruturais contra preconceitos em contextos epistêmicos, dificultando a operação da injustiça testemunhal (Anderson, 2012).

Fricker estabelece uma investigação filosófica sobre uma forma de injustiça epistêmica que pode afetar profundamente a vida dos sujeitos sobre os quais recai. Apesar da importância da sua perspectiva neste trabalho, considero fundamental compreender as críticas a soluções baseadas em virtudes individuais, bem como conceber algum questionamento a respeito de uma 'economia da credibilidade', retomando a visão de Butler (2017) com a qual abri este debate. Procurarei abordar melhor este tópico na discussão específica sobre o refúgio, mas cabe salientar aqui a questão da própria impossibilidade de um processo ético e justo de determinação do status de refugiado que esteja baseado na idéia de credibilidade. Conforme vimos inicialmente, Butler (2017) nos traz a perspectiva da impossibilidade de uma narrativa totalmente coerente do sujeito sobre si mesmo. Ainda que a autora não esteja se referindo explicitamente a julgamentos de credibilidade, consideramos aqui o fato de que a busca por uma narrativa coerente, consistente e plausível constitui a base de toda análise de credibilidade no campo do refúgio, conforme veremos em maiores detalhes no decorrer do trabalho.

Se considerarmos, como afirma Butler (2017), a impossibilidade de sermos seres autobiográficos totalmente coerentes, abraçando, em seu lugar, aquilo que não pode ser facilmente traduzido em forma narrativa (momentos de interrupção, obstrução e indefinição), estaremos abrindo caminho para uma crítica do projeto da credibilidade como algo legítimo a ser empregado em um processo ético e justo de reconhecimento do outro. Abrir mão desse projeto seria, então, rearticular a possibilidade de uma crítica ao regime de verdade e de prova que caracteriza o universo do refúgio.

\section{3}

\section{A injustiça em contexto}

A partir de uma crítica à noção do conhecimento como algo separado das relações de poder, Foucault oferece uma perspectiva para lidarmos com o nexo entre nossas práticas epistêmicas e nosso contexto político-social mais amplo. Ainda que este trabalho utilize conceitos centrais trazidos pela visão filosófica de Fricker sobre injustiça epistêmica, bem como o debate que emerge neste campo, considero relevante dar início à discussão a partir de uma breve reflexão sobre um 
regime de verdade em suas articulações com modos de saber. Conforme afirma Foucault (2013, p.34):

as condições políticas e econômicas de existência não são um véu ou um obstáculo para o sujeito de conhecimento, mas aquilo através do que se formam os sujeitos de conhecimento e, por conseguinte, as relações de verdade. Só pode haver certos tipos de sujeito de conhecimento, certas ordens de verdade, certos domínios de saber, a partir de condições políticas que são o solo em que se formam o sujeito, os domínios de saber e as relações com a verdade.

Em sua obra intitulada "A Verdade e as Formas Jurídicas", produzida a partir de uma série de conferências que o autor realizou na PUC-Rio, nos anos 1970, Foucault apresenta as práticas judiciárias que deram origem a alguns modelos de verdade que, segundo ele, ainda estariam em circulação na sociedade. Tais modelos não estariam em operação apenas na política e nas práticas diárias dos sujeitos, mas também no domínio do conhecimento científico. Em outras palavras: "até na ciência encontramos modelos de verdade cuja formação deriva das estruturas políticas que não se impõem do exterior ao sujeito do conhecimento, mas que são, elas próprias, constitutivas do sujeito de conhecimento" (Foucault, 2013, p.35). Nesse sentido, na base de todo saber e de todo conhecimento o que está em jogo, para o autor, é uma luta de poder, uma vez que "o poder político não está ausente do saber, ele é tramado com o saber" (Foucault, 2013, p.56).

O nexo saber-poder, central na obra de Foucault, chama a atenção para os processos de formulação de verdades, colocando-os em contexto, uma vez que, para o autor, "a própria verdade tem uma história" (idem, p.18). A perspectiva foucaultiana não nos lembra apenas sobre a impossibilidade de uma postura neutra, desinteressada, na produção de conhecimento, mas principalmente sobre a inexistência de um poder sem base na produção de verdades - e, para tanto, o nexo com as formulações de saber se mostra como fundamental. Para Foucault, o que chamamos de verdade pode ser compreendido como o "conjunto de procedimentos que permitem a cada instante e a cada um pronunciar enunciados que serão considerados verdadeiros" (Foucault, 2003, p.233). Não há, assim, verdades únicas, atemporais e universais, mas apenas um conjunto de políticas da verdade, isto é, a produção de verdades em articulação com interesses de poder. Foucault chama a atenção, nesse sentido, para as relações entre os discursos de verdade e os mecanismos de subjugação, uma vez que os grupos mais fortes tendem a estabelecer 
suas verdades particulares como verdades universais, deslocando possibilidades alternativas de verdade provenientes de sujeitos marginalizados.

Em outra obra intitulada “ Nascimento da Biopolítica”, Foucault nos diz o que ele entende por regime de verdade: “articulação, em uma série de práticas, de certo tipo de discurso que, de um lado, o constitui como um conjunto ligado por um vínculo inteligível e, de outro lado, legisla e pode legislar sobre essas práticas em termos de verdadeiro ou falso" (Foucault, 2008, p.23). Para o autor, uma análise dos regimes de verdade estaria ligada, por exemplo, a estudos sobre a história da loucura e da sexualidade. Nesses casos, uma reflexão realizada por Foucault buscou mostrar as interferências que se articularam a uma série de práticas, coordenadas por um regime de verdade, que fizeram com que o que não existe (a loucura ou a sexualidade, por exemplo) pudesse se tornar, de fato, uma coisa inteligível (que continuava não existindo). Em outras palavras, teria sido um determinado regime de verdade, com seu conjunto de práticas, que fez com que aquilo que não existia pudesse ter se tornado uma coisa, um objeto de intervenção. Foucault procura mostrar, então, como o binômio 'práticas/regime de verdade' acaba formando um "dispositivo de saber-poder que marca efetivamente no real o que não existe e submete-o legitimamente à demarcação do verdadeiro e do falso" (idem, p.24).

Há, assim, e conforme nos diz Foucault, por trás de todo saber e conhecimento, uma luta de poder (e pelo poder). O que o autor chama de políticas da verdade pode ser visto como pertencente a um campo complexo de relações de poder que acabam por determinar aquilo que pode ou não ser considerado como verdadeiro. A abordagem breve da perspectiva foucaultiana nos permite dar início aqui a uma reflexão mais pontual sobre o quadro de injustiça hermenêutica, analisado por Fricker, de modo a considerá-lo inserido em um contexto sóciopolítico de práticas de exclusão de determinados saberes. Tendo em mente a crítica a um regime de verdade, torna-se mais fácil compreender a produção de injustiças a partir da marginalização de sujeitos e do estabelecimento da perspectiva de certos grupos como uma verdade absoluta, ou um saber, que se constitui a partir da exclusão injusta de determinados sujeitos de conhecimento. Após a análise de uma dimensão essencialmente hermenêutica da injustiça epistêmica, a ser realizada nos próximos parágrafos, voltarei à discussão foucaultiana sobre a verdade de forma a abrir novas possibilidades de críticas e questionamentos. 
Além da injustiça testemunhal, Fricker analisa um segundo tipo de injustiça epistêmica que está intrinsecamente relacionado à idéia de que "alguns grupos podem sofrer uma desvantagem injusta em fazer sentido de sua própria experiência social" (Fricker, 2007, p.146). Este tipo de injustiça epistêmica é caracterizado pela autora como uma injustiça hermenêutica que demonstra como alguns grupos podem estar em uma posição hermenêutica desvantajosa por inúmeras razões. Um quadro hermenêutico como este traz à tona uma incapacidade cognitiva que, segundo Fricker, impede que um sujeito compreenda algo significativo de sua própria experiência e, assim, possa sofrer um tratamento injusto sem instrumentos adequados para fazer oposição ao mesmo. Tal incapacidade não seria intrínseca ao sujeito, mas produzida em um contexto social que se apresenta como relevante para entendermos a existência de uma lacuna hermenêutica que pode impactar a vida diária de determinados grupos. Uma lacuna hermenêutica pode, então, impedir que alguns sujeitos não só compreendam algo significativo de sua própria experiência, mas também participem ativamente na produção de significados sociais a partir do local que ocupam na sociedade. Fricker (2006) busca, então, explorar a idéia de que a compreensão das experiências sociais é uma esfera composta por práticas epistêmicas, na qual determinados grupos podem ser incapazes de divergir das interpretações distorcidas de suas experiências.

A perspectiva da autora nos ajuda a entender o processo de marginalização hermenêutica que membros de grupos em desvantagem podem sofrer, com a sua sujeição a práticas desiguais de participação no que diz respeito a uma área significativa da experiência social. Em um processo de marginalização hermenêutica, determinados grupos são bloqueados em suas tentativas de acessar conhecimento ou comunicar conhecimento (especialmente àqueles em uma localização socialmente privilegiada), tendo em vista a existência de um gap nos recursos hermenêuticos coletivos ${ }^{15}$ que poderiam ajudar os sujeitos a compreender a própria marginalização que sofrem (McKinnon, 2016).

\footnotetext{
${ }^{15} \mathrm{O}$ termo "recursos hermenêuticos coletivos" é usado para fazer referência a conceitos compartilhados no 'imaginário social' - conceitos amplamente conhecidos e disponíveis para que seja possível compreender algo e compartilhar esta compreensão com outros (McKinnon, 2016). Seriam, segundo Fricker (2007, p.6), "nossas ferramentas compartilhadas de interpretação social". A nomeação de um fenômeno e, portanto, a produção de um conceito a partir de uma experiência, permite sua comunicação ao outro e a possibilidade de estabelecer o terreno do inteligível.
} 
Para Fricker, a marginalização deve ser entendida como um processo que indica subordinação e exclusão de alguma prática social que teria valor para o sujeito atuante (se ele pudesse participar ativamente em tal cenário). Cabe salientar aqui que esta visão da injustiça hermenêutica passa por um processo socialmente coercitivo de marginalização, uma vez que os sujeitos não optam por uma autoexclusão, mas são colocados em uma situação desvantajosa em termos de poder social. A marginalização hermenêutica gera, então, uma estrutura preconceituosa de recursos hermenêuticos coletivos, uma vez que há a produção de interpretações distorcidas de experiências sociais que não tomam por base a visão dos sujeitos do próprio grupo que vivencia a experiência (Fricker, 2006).

Emerge como relevante também, segundo Fricker (2006, 2007), a complexidade das identidades sociais, tendo em mente que um sujeito pode se encontrar marginalizado em um contexto específico, que leve em conta apenas uma parte de sua identidade social ('mulher'), mas não em outros contextos em que outra parte identitária emerge como mais importante para fins de participação ('classe média'). Nesse sentido, “um sujeito marginalizado hermeneuticamente é impedido de gerar significados que pertencem a algumas áreas do mundo social, mas pode manter uma participação total em relação a outras" (Fricker, 2007, p.154).

A complexidade das identidades sociais faz emergir as condições de possibilidade de processos de marginalização hermenêutica que afetam os sujeitos de maneira diferenciada, podendo, conforme nos diz Fricker, afetar os indivíduos enquanto um determinado tipo social, mas não outro. A partir disso, a autora define a injustiça hermenêutica como: "a injustiça de ter uma área significativa da experiência social obscurecida em termos de conhecimento coletivo devido a uma marginalização hermenêutica persistente e ampla" (Fricker, 2007, p.154). Em termos epistêmicos, este tipo de injustiça está relacionado a um mal que deriva de interpretações de experiências sociais de grupos que são apresentadas de maneira preconceituosa ou errônea, uma vez que os sujeitos que pertencem a tais grupos não participam da produção de significados sobre sua própria experiência.

Fricker nos dá alguns exemplos da dinâmica desigual de produção de interpretações e significados sociais: o assédio sexual interpretado como flerte; o estupro no casamento visto como sexo; a depressão pós-parto entendida como histeria; e etc. Não por acaso, todos os exemplos passam pela mulher enquanto sujeito marginalizado hermeneuticamente. A autora desenvolve, então, a injustiça 
hermenêutica como resultado do processo de marginalização e toma como exemplo central para explicar sua análise o quadro do assédio sexual. Em um cenário anterior à conceituação do assédio sexual, nós encontrávamos dificuldade em nomear e comunicar o desconforto causado por determinados comportamentos de homens, especialmente no ambiente de trabalho. Com a segunda-onda feminista nos anos 1960, tais comportamentos foram finalmente nomeados e compreendidos como uma forma de assédio, tornando possível o entendimento e a comunicação desta experiência do assédio sexual, rechaçando a sua interpretação enquanto um flerte inocente (McKinnon, 2016). Antes desta conceituação, havia uma lacuna hermenêutica que poderia impedir tanto a compreensão da própria experiência por parte de nós, mulheres, quanto uma postura de objeção ao assédio e a busca de modos de combatê-lo ${ }^{16}$ (Fricker, 2006).

Em termos morais, e conforme nos diz Fricker, a marginalização hermenêutica causa um preconceito estrutural nos recursos coletivos hermenêuticos que é essencialmente discriminatório, uma vez que afeta os sujeitos em função de seu pertencimento a determinado grupo social em posição de desvantagem nas relações de poder estabelecidas. Assim, é em função de um determinado aspecto da identidade social de um sujeito que se dá um processo de marginalização hermenêutica. Fricker chama este quadro de preconceito identitário estrutural. A partir disso, a autora propõe uma nova definição de injustiça que leve em consideração sua natureza intrinsecamente discriminatória. Assim, a injustiça hermenêutica seria melhor compreendida como: “ a injustiça de ter uma área significativa da experiência social obscurecida em termos de conhecimento coletivo devido a um preconceito identitário estrutural nos recursos hermenêuticos coletivos" (Fricker, 2007, p.155). Para Fricker, o ato de enfatizar o caráter discriminatório da injustiça hermenêutica faz com que haja uma aproximação entre esta e a injustiça testemunhal abordada anteriormente, já que em ambas as injustiças epistêmicas o sujeito sofre um preconceito contra ele em termos de tipo social.

A injustiça hermenêutica, assim como a injustiça testemunhal, pode ser considerada sistemática, uma vez que a marginalização hermenêutica pode significar uma marginalização de tipo sócio-econômico. Assim, segundo Fricker

\footnotetext{
${ }^{16}$ Mais do que isso, e conforme nos diz Hookway (2010), se não há recursos conceituais para entender determinadas experiências, como aquela do assédio sexual, então também não é possível obter e transmitir conhecimento sobre o tema.
} 
(2007, p.156), "se a marginalização acompanha o sujeito em diferentes atividades sociais, além da hermenêutica, então a injustiça hermenêutica à qual dá origem é sistemática". A autora nos diz, então, que o caráter sistemático desta injustiça pode ser visto como parte de um padrão mais amplo de suscetibilidade de um grupo social a diferentes tipos de injustiça. Da mesma forma que a injustiça testemunhal, a injustiça hermenêutica traz seu aspecto de opressão quando levamos em conta tal caráter sistemático, apontando para as desigualdades estruturais de poder.

Embora a autora se detenha sobre uma injustiça hermenêutica sistemática, que marginaliza os sujeitos de maneira persistente e ampla, ela também levanta a possibilidade de um tipo acidental de injustiça que não deriva propriamente de uma desigualdade estrutural de poder, mas de um momento mais pontual de desvantagem em termos de poder. Assim, ainda teríamos uma lacuna hermenêutica coletiva que impede a comunicação inteligível de uma experiência por parte do sujeito que a vive, mas esta lacuna não seria derivada de um contexto social maior, marcado por outras injustiças sociais, que acompanha o sujeito em diferentes relações que tenta estabelecer.

Uma questão importante que emerge neste cenário está relacionada à dimensão da agência. Diferentemente do caso da injustiça testemunhal, uma injustiça hermenêutica, seja ela sistemática ou acidental, não envolve a atuação de um agente responsável por perpetrar tal injustiça - conforme nos diz Fricker, ela é puramente estrutural. Há, assim, segundo a autora, uma condição dormente de injustiça, que acaba revelada nos momentos em que um sujeito busca tornar sua experiência inteligível para ele mesmo ou para um interlocutor.

$\mathrm{O}$ fato de que a injustiça hermenêutica se manifesta em momentos em que o sujeito busca uma troca inteligível sobre determinadas experiências levanta um aspecto fundamental para a discussão: "a injustiça hermenêutica pode ser frequentemente composta pela injustiça testemunhal" (Fricker, 2007, p.159). Ainda que, na injustiça hermenêutica, a ênfase não seja sobre a existência de um déficit de credibilidade, um empobrecimento conceitual pode impedir alguém de articular claramente seu testemunho (Carel e Kidd, 2014). Segundo Fricker, a relação entre as duas dimensões se mostra mais claramente quando a injustiça hermenêutica é sistemática, uma vez que membros de grupos marginalizados tendem a estar sujeitos ao preconceito identitário. Nesse sentido, aquele que busca tornar sua experiência inteligível estaria sujeito a uma dupla injustiça causada tanto pelo 
preconceito estrutural nos recursos hermenêuticos coletivos, quanto pelo preconceito posto em ação pelo interlocutor em julgamentos de credibilidade ${ }^{17}$.

Fricker (2007) enfatiza que a manifestação da injustiça hermenêutica através de trocas comunicativas chama a atenção para um aspecto diferente da injustiça. Até agora, tenho considerado aqui apenas as lacunas em termos de interpretação das experiências sociais dos sujeitos - especificamente aquelas experiências que eles gostariam de tornar inteligível ao outro através do discurso. Porém, a autora também afirma que "devemos reconhecer que um gap hermenêutico pode dizer respeito não somente ao conteúdo, mas também à forma daquilo que pode ser dito" (Fricker, 2007, p.160). Nesse sentido, os estilos narrativos utilizados em trocas comunicativas podem constituir um aspecto importante da injustiça hermenêutica, tendo em vista que alguns grupos sociais podem sofrer de um déficit de credibilidade não somente por problemas na interpretação de suas experiências, mas também na potencialidade de sua auto-expressão.

Assim, para Fricker, possuir uma voz diferente daquela que é esperada pelos grupos em posição vantajosa de poder é algo relevante no contexto da discussão sobre uma forma hermenêutica de injustiça. A autora cita como exemplo o caso das mulheres vistas a partir de um estilo intuitivo, o qual se afastaria de uma imagem reconhecida como racional e apropriada. Nesse contexto, "viver em uma sociedade ou subcultura na qual a mera existência de um estilo expressivo emocional ou intuitivo faz com que alguém não seja ouvido como totalmente racional [...] leva à sujeição a uma injustiça hermenêutica" (idem, p.161).

O tipo de injustiça abordado aqui envolve, então, uma desvantagem cognitiva assimétrica que impacta membros de diferentes grupos de maneiras diversas. Fricker reconhece que tal assimetria emerge de um determinado contexto social e político que permite um empobrecimento nos recursos coletivos hermenêuticos. É exatamente por estar situado em determinado contexto social mais amplo que o empobrecimento coletivo torna possível a existência de assimetrias profundamente injustas em relação a grupos específicos. Conforme

\footnotetext{
${ }^{17}$ Alguns autores, como Hookway (2010), enfatizam que não pode haver justiça testemunhal sem justiça hermenêutica. Segundo o autor, não é possível um julgamento de credibilidade justo se há um gap hermenêutico que impede a compreensão e interpretação do testemunho do sujeito. Para Hookway, os sujeitos marginalizados hermeneuticamente iniciam interações comunicativas a partir de uma posição desvantajosa, uma vez que estariam mal-equipados para fazer sentido de certas experiências e mais propensos a não serem bem compreendidos.
} 
afirma a autora, "lacunas hermenêuticas são como buracos na camada de ozônio são as pessoas que vivem debaixo deles que se queimam" (Fricker, 2007, p.161). Fricker afirma, assim, que a injustiça hermenêutica é um tipo de discriminação estrutural que afeta injustamente alguns grupos específicos que se encontram marginalizados. Segundo ela, o principal dano causado por esse tipo de injustiça consiste em uma desigualdade hermenêutica situada que guarda relação direta com preconceitos identitários estruturais nos recursos hermenêuticos coletivos. Este dano, assim como aquele provocado pela injustiça testemunhal, tem a ver com um modo de operar exclusões preconceituosas que impedem a participação dos sujeitos no compartilhamento do conhecimento. A partir disso, podemos entender a dimensão profundamente epistêmica que está implicada em tal injustiça.

Embora já tenha sido discutida, na seção anterior, a contribuição de Chris Hookway (2010) para a expansão dos casos possíveis de uma injustiça epistêmica, bem como a resposta de Fricker (2010) à crítica, parece relevante ressaltar aqui a compreensão do autor sobre uma "participação epistêmica". Para Hookway, é necessário direcionar a atenção aos tipos de injustiça epistêmica que podem emergir em um quadro de exclusão no que tange à chamada participação epistêmica. Em outras palavras, é preciso levar em consideração a participação dos sujeitos em discussões e deliberações, bem como outros tipos de participação epistêmica que envolveria, por exemplo, avaliar a importância de questões e debates.

Pode haver, assim, uma injustiça epistêmica direcionada ao funcionamento de um sujeito enquanto participante ativo em discussões e deliberações. Embora este quadro pareça similar ao conceito de injustiça hermenêutica, Hookway enfatiza que não há, necessariamente, a ausência de recursos conceituais que permitam a compreensão de uma experiência e sua comunicação a outros. Como exemplo, o autor levanta a possibilidade de um professor que recusa a contribuição de um aluno ao debate filosófico conduzido em sala de aula, considerando o estudante não como um potencial participante na discussão, mas como alguém cuja posição deve estar restrita a levantar ou responder perguntas sem grandes questionamentos. Haveria, então, uma recusa em levar a sério a contribuição do aluno, baseada em uma postura estereotipada deste sujeito enquanto incapaz de participar epistemicamente na produção de conhecimento em torno de temas filosóficos.

Ainda que Fricker (2010) aponte a relevância do aprofundamento do conceito de participação epistêmica - e a injustiça que pode estar implicada neste 
cenário - sua perspectiva permanece voltada aos casos em que um gap existente nos recursos hermenêuticos coletivos opera uma redução significativa na inteligibilidade da troca comunicativa. Assim como na injustiça testemunhal, porém, uma atuação justa por parte daquele que interage com o sujeito posto em situação de desvantagem demanda uma consciência reflexiva. O que a autora chama de virtude da justiça hermenêutica envolveria, então, a sensibilidade do interlocutor no que diz respeito a dificuldades no processo de tornar alguma experiência social inteligível. Para Fricker, a virtude tanto da justiça testemunhal quanto da hermenêutica envolveria condutas epistêmicas conscientes do cenário social mais amplo em que a cena de interpelação e as trocas comunicativas se dão. Uma sensibilidade reflexiva crítica permitiria, então, um tipo de correção dos julgamentos iniciais operados em que a existência de obstáculos à inteligibilidade causou um déficit de credibilidade. Nesse sentido, a autora afirma que em contextos hermenêuticos a grande questão seria uma perspectiva da 'verdade' que permitisse a possibilidade de existência de mais de uma interpretação possível daquilo que é verdadeiro. Sobre isso, Fricker (2007, p.170) afirma:

Em contextos hermenêuticos, então, o julgamento de credibilidade responsável é uma avaliação daquilo que faz sentido em relação ao que foi dito - o grau em que é uma interpretação verdadeira. Agora, nos casos em que os esforços daquele que narra são prejudicados por uma injustiça hermenêutica, o interlocutor virtuoso deve registrar este fato e fazer concessões de forma que seu julgamento de credibilidade inicial seja revisado a fim de compensar os empecilhos.

A partir desta perspectiva, seria necessário, sempre que possível, operar um julgamento de credibilidade que levasse em conta a dificuldade do sujeito em articular suas experiências, tendo em mente a tentativa de produzir um cenário hermenêutico que a autora chama de mais inclusivo. Tal cenário comunicativo seria marcado por uma ausência de preconceito identitário estrutural. Para Fricker, então, o impacto do preconceito da marginalização hermenêutica do sujeito poderia ser corrigido nos julgamentos de credibilidade. Através da atuação de um interlocutor virtuoso seria possível produzir, em uma cena específica de interpelação, um clima hermenêutico mais aberto ao diálogo, desafiando os limites da inteligibilidade. Um diálogo desta natureza envolveria, segundo a autora, um tipo de escuta ativa que fosse mais socialmente consciente do que aquela que ocorre normalmente nas trocas comunicativas. Seria necessário, então, "manter uma mente aberta em relação à credibilidade" (Fricker, 2007, p.172). 
Apesar de levantar a importância de uma postura virtuosa e justa em julgamentos de credibilidade, Fricker salienta também que a marginalização hermenêutica é produto de relações desiguais de poder e, como tal, não se constitui como algo que pode ser resolvido simplesmente por uma mudança de postura em cenas específicas de diálogo e interpelação. Sobre isso, a autora nos diz que: "transformar as relações desiguais de poder que criam as condições para uma injustiça hermenêutica demanda mais do que uma conduta individual virtuosa; demanda uma ação política coletiva em prol da mudança social” (Fricker, 2007, p.174).

Tendo já exposto, ao final da seção anterior, a discussão em torno das formas de combate à injustiça epistêmica - com a possibilidade de mecanismos estruturais e individuais - cabe apontar aqui, ainda que de maneira breve, um caminho para uma crítica externa, que considere a relevância da perspectiva foucaultiana, com a qual iniciei a discussão. Para Foucault (2007), a virtude deve ser concebida como uma relação crítica com as normas pré-estabelecidas, isto é, como uma forma de estar no mundo que busca opor-se às inúmeras maneiras de exercício do poder. Assim, para o autor, a postura crítica que constitui a virtude está diretamente relacionada a uma oposição ao governo: é um não-querer ser governado porque o sujeito concebe este poder como injusto e ilegítimo.

O que a crítica faz, então, é justamente expor essa ilegitimidade por trás dos projetos de poder. Isso não significa aqui uma anarquia radical, mas antes um desejo de oposição a ser governado a partir da consideração dos custos que este governo abarca. A postura crítica e virtuosa, portanto, envolve uma insubordinação voluntária (Butler, 2001). Ao analisar a perspectiva de Foucault sobre a virtude, Butler nos diz que a crítica, para o autor, tem início com o questionamento sobre a demanda de uma obediência absoluta à autoridade. Em outras palavras, seria preciso avaliar, reflexiva e racionalmente, as obrigações que são impostas aos sujeitos por autoridades governamentais ou por modos de governo.

A crítica é, assim, o movimento pelo qual o sujeito da a si mesmo o direito de questionar determinadas verdades e seus efeitos de poder, bem como o direito de questionar o poder em seus discursos de verdade (Foucault, 2007). Trata-se, então, de não aceitar algo como verdade simplesmente porque uma autoridade assim o considera. Isso porque a definição de verdade passa, necessariamente, por relações de poder que circunscrevem determinadas formas de ordenar o mundo de 
modo a torná-lo regular e regulável e a constituir o que vai ser aceito como um campo de conhecimento (Butler, 2001). Conforme nos diz Butler, a partir de sua análise de Foucault, a atitude crítica envolve expor as articulações entre o conhecimento e o poder, as quais operam para produzir um modo mais ou menos sistemático de ordenar o mundo. Nesse sentido, adotar a perspectiva de Foucault acerca da crítica, em sua conexão com a virtude, seria repensá-la como uma prática de questionamento dos limites do conhecimento, daquilo que podemos saber e, portanto, de todo um campo epistemológico (Butler, 2001). Para compreendermos a emergência e a manutenção de um campo de coisas inteligíveis e, assim, as próprias fronteiras da inteligibilidade, seria preciso voltar nossa atenção para as relações entre o conhecimento e o poder. Em outras palavras: “um nexo saber-poder tem que ser descrito para que seja possível compreender o que constitui a aceitação de um sistema" (Foucault, 2007, p.58). Este sistema guarda, portanto, "sua arbitrariedade em termos de conhecimento e sua violência em termos de poder" (idem, p.59).

A adoção de uma perspectiva foucaultiana da crítica permite vislumbrar mais do que uma postura de virtude constituída por sua abertura e sensibilidade em julgamentos de credibilidade. Aqui, não se trata tanto de pequenos ajustes na capacidade de escuta e nos modos de avaliação das verdades do outro, mas da consciência reflexiva sobre as relações entre o conhecimento e o poder. Um quadro de injustiça hermenêutica, constituído por uma dimensão essencialmente estrutural, não permite que a preocupação com uma postura virtuosa e justa deixe para depois alguns questionamentos básicos sobre nossas certezas epistemológicas. Assim, mais do que uma crítica circunscrita ao espaço de interação testemunhal, considero a necessidade de abrir caminho para o debate mais amplo sobre como práticas epistêmicas podem apoiar determinados modos de estruturação e ordenamento das coisas.

A proposta de análise desenvolvida aqui, sobre o refúgio como problema ético-epistemológico, não pretende, então, deter-se sobre expectativas de análises de credibilidade mais favoráveis aos sujeitos refugiados, mas sim repensar como as verdades do refúgio expõem os limites da inteligibilidade do encontro entre o eu e o outro. Em sintonia com as considerações finais sobre uma injustiça testemunhal, a própria existência de julgamentos de credibilidade pode ser questionada tendo em vista a impossibilidade de um projeto auto-narrativo totalmente coerente. Restringir 
a crítica aos espaços de interação entre o refugiado e seu interlocutor, em momentos de busca da verdade, seria ignorar como a própria constituição do refúgio pode impedir modos alternativos de ordenamento e produzir formas globalizadas de injustiça epistêmica. É, ainda, nesse sentido, que vejo este debate não como circunscrito a uma análise do caso brasileiro, mas como uma reflexão que abre caminho para o questionamento de padrões mais amplos e estruturais do tratamento ético-epistemológico dado aos sujeitos na condição refugiada - e em busca dela.

\section{4 \\ O refúgio à luz da injustiça epistêmica}

Na parte final deste capítulo buscarei abordar a questão do deslocamento à luz da perspectiva teórica analisada anteriormente, dando ênfase à necessidade de repensar como algumas das discussões sobre injustiça epistêmica podem nos ajudar a entender o universo do refúgio. Não se trata aqui de debater movimentos migratórios em geral, mas sim os processos específicos de determinação do status de refugiado e os espaços habitáveis reservados a estes sujeitos. Compreendo esta finalização do primeiro capítulo como uma forma de introduzir as análises realizadas no restante da tese, tanto a partir das entrevistas e trabalho de campo, quanto a partir de uma abordagem com corpus que permite uma análise midiática sobre a imagem do refugiado. Reconheço, assim, uma ênfase sobre a produção epistêmica de sujeitos pelo sistema, através de uma reflexão sobre o processo de determinação do status de refugiado, mas sem prescindir de considerações acerca de uma injustiça hermenêutica possível, que excede os processos do refúgio e transborda para a representação midiática dessa experiência.

Considero relevante iniciar com as práticas epistêmicas que constituem modos de verificação da verdade nas narrativas dos solicitantes e a produção de um regime de verdades do refúgio ao qual o sujeito deve se encaixar a fim de que lhe seja atribuído o status de refugiado. Ainda que a perspectiva teórica desenvolvida por Fricker (2007) não tenha partido de paralelos com tal cenário, não conseguimos deixar de pensar nas práticas epistêmicas deste universo no decorrer das considerações da autora sobre reproduções de modos de injustiça em uma “economia da credibilidade”. Conforme nos diz Toledo de Souza (2016, p.33): “o reconhecimento do status de refugiado, de acordo com as regras do sistema, deve 
ser amparado numa história verdadeira, implicando que o instituto do refúgio depende de mecanismos de busca e produção da verdade sobre a trajetória do solicitante". Tendo em mente, então, a centralidade de modos de verificação da verdade no universo do refúgio, e suas possíveis implicações sobre a vida dos sujeitos, os procedimentos de análise de credibilidade emergem como cruciais para esta análise.

A importância da credibilidade para fins de determinação do status de refugiado emerge da natureza especial de um processo de refúgio que, diferentemente de outros processos jurídico-administrativos, usualmente não pode contar com provas ou evidências oferecidas pelo solicitante de refúgio. Assim, ganha papel de destaque a narrativa dos sujeitos e a credibilidade que lhes é atribuída ou negada. Sem provas materiais e documentais que possam comprovar a existência de um "fundado temor de perseguição", expressão-chave do processo, grande parte da determinação da elegibilidade do sujeito passa a depender, então, da sua narrativa (Sweeney, 2009; Weston, 1998). A partir disso, fundamenta-se uma defesa da importância das análises de credibilidade no instituto do refúgio, no Brasil e no mundo - ainda que fique a cargo de cada país determinar os procedimentos específicos que devem orientar a concessão do status de refugiado. Mesmo ausente da Convenção de 1951, relativa ao estatuto dos refugiados, a análise de credibilidade passa a ser vista como uma das etapas mais importantes na determinação da condição refugiada. Não basta, assim, que o solicitante alegue um "fundado temor de perseguição", mas é preciso que sua narrativa seja posta à prova, que seu corpo, sua fala e seu comportamento sejam investigados em busca da verdade, conforme veremos em detalhes no caso brasileiro, analisado nos próximos capítulos.

Mesmo que cada Estado detenha a liberdade para determinar os procedimentos pelos quais um sujeito deve ou não ser reconhecido como refugiado, permanece relevante a análise de credibilidade em diversos contextos. Tal análise é comumente orientada por um amplo arcabouço normativo composto por manuais de determinação de status, produzidos pelo Alto Comissariado das Nações Unidas para Refugiados (ACNUR) em parceira com outras instituições. Ainda que o objetivo não seja analisar aqui cada prática local de credibilidade, e apesar das distinções em cada processo, permanece em atuação "uma investigação sobre a verdade do solicitante. Sobre sua credibilidade e sua sinceridade. E sempre como 
pressuposto de que os solicitantes estão tentando enganar os julgadores" (Toledo de Souza, 2016, p.29). Poderíamos afirmar, com certa tranqüilidade, que o modo como a análise de credibilidade é posta em prática demonstra sua relação com a ideia de estabelecimento da verdade quanto à narrativa do solicitante. A ênfase do processo de determinação da condição refugiada recai, assim, sobre a visão subjetiva e pessoal dos julgadores quanto à possibilidade de que o solicitante seja, de fato, uma "pessoa verdadeira" (Weston, 1998). Este quadro não é abordado aqui a partir de análises comparadas dos processos de cada Estado, mas sim tendo em vista uma ampla gama de literatura na área que discute a questão, muitas vezes desde contextos locais de cada autor.

O refúgio por elegibilidade, no Brasil e no mundo, é marcado por procedimentos de busca da verdade na tentativa de revelar - e produzir - o sujeito refugiado merecedor do estatuto. Neste contexto, as análises de credibilidade procuram estabelecer narrativas críveis e lançar luz sobre supostas inautenticidades, fazendo com que, muitas vezes, o refugiado se veja diante de um verdadeiro tribunal. Em diferentes Estados, "os solicitantes são avaliados e valorados individualmente, através de processos inquisitivos, nos quais o exame sobre a veracidade tem mais importância do que as informações objetivas sobre o país" (De Souza, 2016, p.29). O caráter imediato e urgente da fuga, as condições burocráticas, sociais e políticas nos países de origem, e outras questões diversas emergem como empecilho para a documentação completa dos solicitantes na sua chegada a um novo país de suposta acolhida. Conforme dito anteriormente, tais condições específicas do processo de refúgio aumentam a importância concedida à análise de credibilidade.

Diante deste quadro, o testemunho ou a narrativa do solicitante de refúgio emerge como questão central para fins de avaliação. Em outras palavras, o depoimento do solicitante "se torna o principal ou único meio de prova. Por esta razão, a entrevista pessoal com os solicitantes de refúgio se torna, na maior parte dos casos, o momento mais importante do processo" (idem, p.32). Veremos, no decorrer dos próximos capítulos, como são as dinâmicas de tais entrevistas no caso brasileiro e como esta prática orienta (e é orientada por) diversas etapas do processo de determinar quem é um refugiado.

Emergem, assim, como aspecto fundamental dos processos de refúgio, os espaços de troca testemunhal entre o solicitante e um interlocutor responsável por 
determinar a credibilidade do sujeito e de sua narrativa. A importância do testemunho nesse cenário não chega a ser uma surpresa, uma vez que nosso conhecimento acaba sendo dependente, em grande parte, da palavra dos outros, produzindo um quadro de dependência epistêmica em relação ao testemunho (Hardwig, 1991; Lipton, 1998). Partimos aqui da definição básica de testemunho, conforme proposta por Robert Audi (2003), isto é, algo que pode ser visto como um tipo de dizer que está direcionado a uma ou mais pessoas.

Como parte central da concepção de Audi acerca do testemunho também é possível encontrar o papel da credibilidade, retomando o nexo entre esta e as trocas testemunhais no processo de refúgio. Conforme nos diz o autor, tanto a testemunha quanto o conteúdo de sua narrativa precisam soar críveis para o interlocutor, ressaltando o papel central da confiança. Seria preciso, assim, que aquele que testemunha emergisse como uma pessoa crível aos olhos do interlocutor, a fim de produzir neste sujeito uma disposição geral para acreditar nela (Audi, 2003). Nesse sentido, "essa disposição é fortalecida se ela [a testemunha] fala com uma evidente credibilidade" (idem, p.135). Para determinar o caráter crível de um sujeito e sua narrativa em uma troca testemunhal a percepção desempenha, para Audi, uma função fundamental. Seria através da percepção daquilo que é dito que se torna possível formar uma crença, ou confiança, baseada no testemunho.

Apesar de não discutir o que pode ser compreendido por uma "evidente credibilidade" e "disposição geral para acreditar", considero importante a perspectiva da epistemologia proposta por Robert Audi por abrir caminho para uma discussão do caráter subjetivo dos julgamentos de credibilidade. O papel da percepção, profundamente subjetivo, pode trazer para o debate uma dimensão não só epistêmica do testemunho, mas também ética. Conforme nos diz Shapin (1994), autor interessado em estudar como as definições de verdade são produzidas em diferentes comunidades, a decisão sobre aquilo em que acreditar é uma questão também sobre em qual sujeito confiar. Shapin procura evidenciar, assim, como determinadas comunidades conseguiram determinar qual testemunho aceitar e qual rejeitar, elucidando os aspectos morais e éticos do testemunho e ressaltando a conexão entre epistemologia e ética (Lipton, 1998). O nexo entre julgamentos morais/éticos e a confiança no testemunho do outro é articulado também por Hardwig (1991, p.702), que afirma que "essa confiança envolve confiar no caráter daqueles que testemunham”. Nesse sentido, a partir de uma análise da relevância 
do testemunho para fins de cooperação epistêmica e, portanto, de produção do conhecimento, Hardwig (idem, p.708) ressalta que "se muito do nosso conhecimento se baseia na confiança no caráter moral daqueles que testemunham, então o conhecimento depende da moralidade e a epistemologia também requer a ética".

O papel central que a confiança exerce nas trocas testemunhais e nas nossas práticas epistêmicas diárias ressalta, então, o aspecto ético e moral da epistemologia. Conforme afirma Shapin, o conhecimento depende diretamente das relações que estabelecemos com outros e tais relações são morais no sentido da importância exercida pela confiança. A questão que emerge para o autor nesse contexto é: em quem confiar? A identificação de atores confiáveis é vista por Shapin como necessária para a produção de conhecimento, que mobiliza apreciações particulares das virtudes e características de certos tipos de pessoas. Através de sua análise, Shapin nos mostra como determinadas comunidades formulam seus paradigmas culturais dos tipos de indivíduos em que é possível confiar, ou seja, quais os sujeitos dignos de confiança por serem vistos como aqueles que falam a verdade.

A perspectiva do autor traz, assim, a confiança enquanto uma instituição social que deve ser alvo da investigação da sociologia, a fim de que seja possível refletir sobre como o testemunho de alguns sujeitos é alocado em uma posição de fonte verdadeira de informação e conhecimento. Embora alguns autores, como Lipton (1998), critiquem a ênfase em uma dimensão moral dos testemunhos, afirmando que a decisão sobre em quem confiar também passa por uma apreciação do conteúdo das narrativas, a perspectiva exposta aqui levanta a importância do nexo entre epistemologia e ética. Buscarei voltar a essa discussão no debate sobre a reprodução de formas de injustiça epistêmica. Mas, por ora, é preciso ter em mente que a confiança exerce um papel significativo na atribuição de credibilidade a determinado testemunho e que isso ocorre de maneira diferenciada dependendo, em grande medida, da identidade dos sujeitos.

$\mathrm{Na}$ experiência do refúgio a confiança também exerce papel central, sendo constantemente posta em julgamento e superada pela desconfiança (Daniel e Knudsen, 1995). Embora o colapso da confiança não ocorra apenas no país de acolhida, havendo já um rompimento da mesma no país de origem em relação a instituições e governos, por exemplo, destaco aqui o cenário dos julgamentos de 
credibilidade nas solicitações de refúgio. A troca testemunhal, especialmente nos momentos de entrevista com solicitantes, acaba sendo constituída - e experimentada - como uma confrontação ao invés de um diálogo baseado na confiança (Daniel e Knudsen, 1995). Os espaços de encontro com o outro se desenvolvem, assim, a partir do próprio julgamento daquele em quem é possível confiar. Não seria, porém, apenas uma questão da desconfiança do interlocutor em relação ao que o solicitante ou refugiado diz, mas também uma desconfiança da parte destes sujeitos no que concerne ao uso das informações providas na interação. Embora seja uma perspectiva menos comum nas análises, também emerge como relevante pensar a necessidade do refugiado estar livre para prover informações e sentir-se seguro de que nada do que disser será usado contra ele (idem). Em ambas as dimensões da interação, a questão da confiança se desenvolve como um problema central que afeta a credibilidade concedida ao testemunho dos sujeitos, o que pode se traduzir na (re)produção de formas epistêmicas de injustiça, conforme veremos no terceiro capítulo.

As práticas da elegibilidade ganham um valor significativo com a emergência de conhecimentos locais que fazem com que os oficiais responsáveis por determinar a credibilidade transmitam uns aos outros uma mensagem de desconfiança em relação aos sujeitos que solicitam o refúgio (Jubany, 2011). Ganha destaque, nesse cenário, o desenvolvimento de práticas epistêmicas dos profissionais que buscam identificar as mentiras supostamente atreladas às narrativas dos solicitantes. A partir do seu trabalho de campo no Reino Unido, Jubany nos mostra como os oficiais aprendem em suas práticas diárias não sobre os direitos dos refugiados, mas sobre as técnicas para identificar mentiras e revelar as verdades do refúgio.

Os julgamentos de credibilidade dão forma, assim, a um processo de elegibilidade que acaba se tornando uma busca incessante da verdade em prol da proteção do próprio estatuto de refúgio, já que "no mundo dos oficiais, a crise existe apenas sob a forma dos números e do abuso do sistema” (Jubany, 2017, p.4). Os solicitantes passam a ser vistos, então, como sujeitos indignos de confiança, uma vez que estariam manipulando o sistema de imigração em busca de um status que não mereceriam. Nesse sentido, o que está em jogo é o próprio caráter do solicitante, já que os julgamentos de credibilidade são baseados em suposições sobre sua honestidade (Griffiths, 2012). Isso ressalta, novamente, a dimensão moral e ética 
de uma prática epistêmica que busca ganhar conhecimento sobre situações políticas e sociais a partir do testemunho. No terceiro capítulo desta tese busco analisar em maiores detalhes o papel da desconfiança no processo brasileiro de refúgio e o que isso pode significar em termos de produção de uma injustiça testemunhal.

Jubany também expõe, em sua análise crítica sobre uma cultura da descrença no universo do refúgio, o papel de estereótipos e preconceitos nas determinações do status de refugiado. Segundo a autora, os critérios utilizados pelos oficiais para avaliar os solicitantes de refúgio não são propriamente derivados de regulamentos ou leis, mas das próprias categorizações dos sujeitos e de valores que “derivam de estereótipos ambíguos nutridos pelas experiências dos oficiais e seus preconceitos sociais" (Jubany, 2011, p.2). Os oficiais, "treinados para desacreditar" (idem, p.9), utilizam sua experiência e "expertise" para decidir as verdades do refúgio, aplicando "sua subjetividade sem nenhuma outra justificativa além de uma série de preconceitos determinados pelo grupo" (idem, p.15). Legitima-se, assim, o que a autora chama de uma cultura da descrença.

Os atores responsáveis pelos julgamentos de credibilidade acabam atuando através de suas próprias expectativas sobre o comportamento ideal dos sujeitos, sobre a suposta realidade objetiva em um Estado, sobre a plausibilidade de experiências sociais - tudo isso partindo normalmente de um senso de "intuição ou instinto profissional" (Jubany, 2011, p.14). Tal intuição ou instinto ao mesmo tempo em que se constitui como um critério poderoso neste universo da elegibilidade, também se apresenta como um dos mais ambíguos ao manifestar a pressuposição de que o oficial ou ator envolvido no processo pode "sentir" a força ou fraqueza de uma solicitação de refúgio (idem). Esta discussão é desenvolvida em detalhes no segundo capítulo, com a análise de como distintos atores do universo institucional do refúgio no Brasil determinam a força ou fraqueza de um caso, avaliando, assim, a credibilidade do solicitante.

Os julgamentos de credibilidade direcionados ao testemunho dos solicitantes de refúgio emergem, assim, como um processo altamente subjetivo, amplamente desvinculado de regulamentos legais e saturado por uma metamensagem de descrença e negação (Jubany, 2017). Para Jubany, o refúgio passou a ser constituído como uma questão de erosão da confiança diante de uma ameaça onipresente que o solicitante supostamente representaria. Não é, segundo a autora, um problema de proteção do refugiado, mas sim de proteção do Estado em relação 
aos refugiados e solicitantes. Há nesta perspectiva uma relação direta entre uma visão do refugiado enquanto ameaça e uma imagem do refúgio atravessada por mensagens de suspeita e descrença. Os oficiais responsáveis por julgar a credibilidade dos sujeitos são formados, então, através de treinamentos que ajudam a estabelecer a "construção social de certas verdades como conhecimento" (idem, p.116). Ao acompanhar os treinamentos dos oficiais, Jubany se dá conta de que os regulamentos e leis perdem espaço diante da necessidade de revelar verdades, o que se torna essencial para o desempenho dos oficiais no processo de refúgio. Emerge também a importância, conforme dito aqui anteriormente, dos momentos de entrevista com os solicitantes. Segundo Jubany (2017, p.121):

Conforme os elementos investigativos dos papéis dos oficiais são desenvolvidos, o curso introduz técnicas e habilidades de entrevista como centrais à entrevista do refúgio. Neste estágio relativamente inicial do curso, a entrevista se torna o tema dominante, com estratégias de questionamento focando no estabelecimento da credibilidade nas narrativas dos solicitantes de refúgio. Tanto as estratégias de entrevista quanto as de credibilidade formam uma parte fundamental do conteúdo do curso.

Apesar de a credibilidade ser transmitida como uma análise objetiva dos fatos concernentes à solicitação de refúgio, Jubany expõe como todo o treinamento dos oficiais se desenvolve a partir de mensagens de desconfiança e busca da verdade que abrem espaço para dimensões altamente subjetivas da figura do refugiado ideal. Algumas emoções específicas, por exemplo, são esperadas dos sujeitos, que devem se adequar ao imaginário dos oficiais em relação ao que é esperado do comportamento de alguém em situação de refúgio. Nesse sentido, não só o testemunho, mas também as emoções, o comportamento e o corpo dos sujeitos devem passar pelo teste da credibilidade. Não se trata, assim, de construir um espaço de interação que permita a experiência do refúgio em seus próprios termos, mas sim de implementar técnicas de interrogatório que busquem revelar os tipos que mais se adequariam às verdades do refúgio mantidas pelos oficiais. Segundo Jubany (2017, p.133), “conforme os estudantes aprendem seus papeis de entrevistadores, conceitos como a credibilidade, centrais nas decisões de refúgio, se tornam ligados ao conceito da desconfiança". Torna-se evidente, então, que "o papel dos oficiais não é simplesmente entrevistar, mas interrogar os solicitantes" (idem, p.134). A imagem do interrogatório é reproduzida entre alguns atores no 
caso brasileiro, conforme veremos no próximo capítulo, trazendo à tona o espaço de troca da entrevista de refúgio como uma prática deliberadamente investigativa.

No decorrer de sua análise sobre as práticas de determinação de status no Reino Unido, Jubany deixa claro como técnicas policialescas de interrogatório são utilizadas no treinamento e no dia-a-dia dos oficiais responsáveis pelos julgamentos de credibilidade. Nesse cenário, e ainda segundo a autora, os solicitantes e refugiados são vistos como suspeitos, os agentes de fronteira são tidos como investigadores e o objetivo do processo é revelar as mentiras nas narrativas. Não há, assim, um espaço de troca e diálogo, mas um interrogatório em busca de potenciais fraudes e trapaças (Jubany, 2017). A perspectiva da verdade, porém, é atravessada pelo etnocentrismo e pelos preconceitos dos oficiais que percebem o solicitante de refúgio como o "outro" a partir das lentes herdadas do colonialismo e do racismo (idem). A partir disso, “um solicitante de refúgio arquetípico é construído através de práticas diárias a fim de se tornar o princípio-guia por trás da entrevista" (idem, p.186).

$\mathrm{Na}$ análise do caso brasileiro, realizada nos próximos capítulos, poderemos ver como a credibilidade é postulada como algo dado, revelado ou não pelo solicitante, e não como uma construção através das práticas dos oficiais de atribuir ou negar credibilidade aos sujeitos e seus testemunhos, obedecendo a imagens do refugiado ideal - atravessadas também por preconceitos e estereótipos. Embora a discussão sobre figuras estereotipadas do refugiado percorra toda a análise, o final do terceiro capítulo aborda em maiores detalhes como estereótipos e preconceitos afetam a relação com o refugiado, excedendo também o espaço processual.

A perspectiva trazida por Jubany a partir do seu trabalho de campo ressalta, então, a prevalência de um conhecimento profissional dos oficiais enquanto um grupo, que acaba por utilizar sua experiência e intuição como uma espécie de sexto sentido para revelar mentiras e verdades. A credibilidade é comumente atribuída a partir de uma perspectiva da plausibilidade que orienta os oficiais sobre o que, segundo sua própria visão, poderia ou não ter acontecido. O ponto de partida é a experiência social do próprio sujeito responsável por realizar o julgamento da credibilidade, o qual produz parâmetros para determinar o cenário do possível dentro das narrativas do refúgio. O que é operacionalizado nas interações testemunhais passa a ser a imagem que os oficiais carregam das sociedades, dos sujeitos e dos comportamentos normais ou apropriados em cada diferente contexto. 
Conforme nos diz Jubany, "para os oficiais, as coisas que não se conformam as suas expectativas sócio-culturais não possuem credibilidade e são tidas por eles como não fazendo sentido" (Jubany, 2017, p.194).

A credibilidade, segundo a crítica estabelecida por Jubany, é entendida como aquilo que soa "lógico" ou "normal" para os oficiais - para um testemunho ser tido como crível é preciso, em última instância, que a história narrada pareça lógica. Dessa maneira, entram em cena aqui as expectativas e noções pré-formadas sobre os próprios países de origem dos solicitantes, ajudando a estabelecer os limites do crível nas narrativas sobre violência e perseguição que alguns solicitantes trazem consigo. Os oficiais são responsáveis por estabelecer, através de um julgamento de credibilidade, as fronteiras do que pode e do que não pode ser.

Apesar da perspectiva proposta por Jubany ter partido de um trabalho de campo situado no Reino Unido, as considerações da autora dialogam com grande parte dos estudos sobre as análises de credibilidade no universo do refúgio. Tais estudos, muitas vezes realizados com base em diferentes situações locais, ressaltam dimensões importantes que, por sua vez, dialogam com o quadro de injustiça epistêmica que utilizamos aqui. A análise de credibilidade em processos de refúgio leva em consideração três aspectos centrais: a consistência externa, isto é, se o testemunho do solicitante está de acordo com outras evidências objetivas e fatos gerais conhecidos sobre seu país de origem; a consistência interna, ou seja, se o testemunho é bem detalhado e não apresenta contradições; e a plausibilidade ou a possibilidade de que aquilo que está sendo narrado possa ter acontecido ou possa vir a acontecer (ACNUR, 2013; Kagan, 2003; Sweeney, 2009; Weston, 1998). A partir disso, é possível afirmar que os julgamentos de credibilidade se orientam em torno de alguns elementos ou princípios considerados primordiais, como: comportamento e comunicação não-verbal por parte do solicitante; comparação do testemunho do sujeito com evidências independentes (pesquisas de especialistas sobre o país de origem do solicitante); e detalhamento e coerência das narrativas (Kagan, 2003).

Um dos aspectos centrais que a perspectiva teórica de Fricker sobre a injustiça testemunhal traz diz respeito à atuação de preconceitos e estereótipos nos julgamentos de credibilidade. Conforme vimos detalhadamente aqui, a articulação entre um grupo social e generalizações sobre este mesmo grupo pode fazer com que a percepção do interlocutor em relação ao testemunho de um sujeito se torne 
distorcida. As imagens possuem, então, um impacto significativo em termos do julgamento de credibilidade, podendo produzir casos de injustiça epistêmica do tipo testemunhal. As dimensões centrais das análises de credibilidade nos processos de refúgio indicam a importância das expectativas dos oficiais em relação ao solicitante, conforme vimos com Jubany. Alguns traços físicos e comportamentais são comumente atribuídos a certos grupos nacionais, fazendo com que os sujeitos sejam percebidos enquanto tipo social. Isso produz não somente a expectativa de como um solicitante de refúgio de determinada nacionalidade deve se comportar, mas também de como ele deve apresentar algumas características natas que o faz, por exemplo, dramatizar ao extremo sua própria história, gerando um sentimento de descrença por parte do oficial de elegibilidade (Jubany, 2011, 2017). Isto afetaria, então, a plausibilidade de uma narrativa e, por vezes, até sua consistência interna, que acaba dependendo também das percepções e expectativas dos oficiais sobre como um determinado testemunho deve se desenvolver e como o sujeito que narra deve se comportar.

Através de um processo contínuo de categorização dos sujeitos, os oficiais de elegibilidade determinam quais tipos de pessoas de certos países irão solicitar refúgio e quais tipos de histórias elas trarão consigo (idem). Tais expectativas e percepções se aplicam não somente à identidade de um solicitante e ao conteúdo de sua narrativa, mas também ao comportamento e às emoções que são acionados na troca testemunhal. A importância desses fatores parte da premissa de que certos padrões de comportamento são indicativos de credibilidade, o que inclui como o indivíduo se porta diante de uma entrevista de elegibilidade, seu nível de nervosismo, a coloração de sua pele durante questões difíceis, o ritmo de sua fala e a demonstração de emoções ao narrar certos eventos traumáticos. Tais fatores são vistos, então, como potenciais indicativos do caráter verdadeiro de uma solicitação de refúgio.

O processo acaba orientado, nesse sentido, por uma série de expectativas não razoáveis sobre como os sujeitos podem expressar suas emoções e seus próprios estilos narrativos (Graham, 2002; Rousseau et.al, 2002), gerando um ambiente em que as diferenças culturais acabam transformadas em uma só "cultura da descrença" (Alexander, 1999; Jubany, 2011, 2017; Souter, 2011; Weston, 1998). Nos próximos capítulos veremos como, no caso brasileiro, as práticas das entrevistas de refúgio reforçam ideais de comportamento e sua relação com o fator "nacionalidade", 
enquanto desenvolvem-se tentativas de gerenciamento de expectativas no processo brasileiro de elegibilidade.

Os sujeitos que não se enquadram nas expectativas e percepções dos oficiais de elegibilidade são comumente vistos como impostores, falhando no teste que os definiria como "uma pessoa verdadeira" (Weston, 1998). Conforme nos diz Graham (2002), o status de refugiado verdadeiro está em perigo caso o solicitante apresente suas emoções em desacordo com o estereótipo do comportamento apropriado, que inclui falta de agência e iniciativa, depressão ou tristeza, relação com autoridades marcada por poucas demandas e por um espírito de gratidão. $\mathrm{O}$ afastamento de tais expectativas e estereótipos pode gerar a recusa das solicitações com base em uma suposta falta de autenticidade, fazendo com que o solicitante de refúgio se depare com "um muro de indiferença burocrática" (Graham, 2002, p.211).

Os julgamentos de credibilidade acabam ajudando a produzir as próprias verdades do refúgio, baseadas em expectativas, percepções e imagens subjetivas dos oficiais de elegibilidade, que criam uma única cultura da descrença. Espera-se que os sujeitos pensem e vejam o mundo a partir das categorias dos oficiais, ignorando, por exemplo, as diferentes percepções de tempo, espaço e individualismo (Kalin, 1986). Assume-se, nesse contexto, uma idéia universal de bom senso que sustenta o argumento de que um testemunho não deve contrariar "a experiência comum da vida" (idem, p.236), o que se traduz no critério da plausibilidade já discutido aqui.

Ainda que os processos de refúgio envolvam práticas complexas de tradução e interpretação cultural e lingüística (Gibb e Good, 2014), a pluralidade de modos de vida acaba reduzida a uma única cultura marcada pelas imagens da desconfiança em relação à honestidade e sinceridade dos solicitantes de refúgio. Conforme afirma Griffiths (2012), é possível notar uma ênfase institucional no caráter de verdade e na imagem endêmica do solicitante como um sujeito mentiroso, oportunista e trapaceiro. Há, então, uma construção subjetiva que define quem diz a verdade e quem mente, baseada em expectativas de como os solicitantes lembram, pensam e se comportam, e em premissas culturais em relação ao que constitui o bom senso e outros estereótipos (Griffiths, 2012). A confiança, fator central para julgamentos de credibilidade, acaba sendo articulada às experiências, percepções e expertise dos oficiais responsáveis por determinar as verdades do refúgio (Jubany, 2017). 
Exige-se do solicitante um relato coerente, uma confissão detalhada dos seus medos, a demonstração adequada de suas emoções e o uso perfeito da memória do trauma. A cena de interpelação, ou a troca testemunhal, acaba se constituindo como um espaço de reprodução de relações desiguais de poder no qual uma das partes estabelece, a priori, quais países podem ser vistos como produtores de refugiados, quais testemunhos podem ser concebidos como verdadeiros e críveis e qual linguagem comportamental é mais adequada para cada medo ou violência relatado. Nos próximos capítulos, veremos como esta posição privilegiada por parte de determinados atores e oficiais do processo de determinação do status de refugiado pode ajudar a produzir um quadro de injustiça epistêmica no cenário brasileiro.

Se entendermos o preconceito identitário nos termos propostos por Fricker, isto é, em relação estreita com os estereótipos, poderemos interpretar os julgamentos de credibilidade nos processos de refúgio como potenciais produtores de uma injustiça testemunhal. Conforme vimos com Jubany (2017), os solicitantes de refúgio são julgados a partir de critérios que, fora do âmbito de uma subcultura dos oficiais de elegibilidade, podem ser vistos como uma série de preconceitos que reconhecem o migrante não-ocidental como o "outro" sob a lente do racismo. Torna-se comum a atribuição de déficits de credibilidade com base em estereótipos sobre como os membros de cada grupo social devem se comportar e quais tipos de história devem trazer consigo.

A demonstração apropriada de emoções, por exemplo, está ligada não apenas a uma determinada imaginação social distorcida sobre como alguém de certo tipo social (refugiado) deve se comportar ao narrar traumas e temores, mas também a uma pré-concepção sobre como deve ser relatar uma determinada experiência de violência. Conforme nos diz Jubany (2017), casos que envolvem tortura e estupro, por exemplo, costumam ser aqueles que demandam uma demonstração intensa de emoções a fim de que o testemunho seja concebido como crível. Nesse sentido, espera-se, dentre outras coisas, que as mulheres chorem ao relatar uma violência sexual ou não queiram narrar sua história diante de outros homens. Um possível afastamento desta imagem ideal do comportamento e das emoções adequadas acaba levantando questões sobre a credibilidade do testemunho e do próprio sujeito.

Ainda que o discurso oficial sobre os processos de determinação do status de refugiado afirme o caráter legal e objetivo das decisões, discussões teóricas diversas já abordaram como a avaliação dos pedidos transforma não só a lei, mas a 
política, em práticas (Alexander, 1999; Kagan, 2003; Rousseau et.al., 2002; Saltsman, 2014). Seja na determinação do chamado fundado temor de perseguição, seja na produção (formal ou informal) de listas de países seguros, considerações políticas parecem ocupar espaço nas decisões sobre as solicitações de refúgio. A figura do refugiado merecedor do estatuto é construída no âmbito de relações desiguais de poder que estabelecem, dentre outras coisas, quais Estados podem ser vistos como "produtores" de refugiados e quais narrativas podem ser vistas como verdadeiras e críveis. O debate anterior que desenvolvi até aqui procurou estabelecer um panorama geral do caráter extremamente subjetivo dos critérios empregados para determinar a elegibilidade dos sujeitos solicitantes de refúgio. Nesse sentido, transformar a interpretação subjetiva em elementos que irão fundamentar decisões postas como legítimas passa, necessariamente, pelo poder discricionário dos oficiais (Saltsman, 2014).

O refúgio pode ser compreendido como um espaço para além dos regulamentos e leis, em que diferentes grupos de poder fazem valer suas interpretações acerca da identidade do refugiado (Saltsman, 2014). Fica a cargo dos oficiais responsáveis pelos julgamentos de credibilidade a interpretação dos comportamentos adequados expressos por um solicitante, a consideração sobre a sinceridade e honestidade das narrativas expostas, bem como a plausibilidade em relação ao país de origem ou à nacionalidade daquele que solicita o refúgio. A discricionariedade do poder político se manifesta, então, no cenário de interpretações subjetivas e abertas a especificações posteriores, ainda que consiga reter sua aura de enquadramento puro e simples à lei. As decisões que concedem um déficit de credibilidade aos sujeitos e suas narrativas, por exemplo, emergem como legítimas por uma suposta falta de apoio empírico e enquadramento legal de determinada solicitação, mesmo que controvérsias sobre a elegibilidade dos sujeitos não tenham sido esgotadas pelas práticas políticas de determinação da condição refugiada (Magalhães, 2014, 2016).

Ainda que eu esteja me detendo aqui, principalmente, sobre as trocas testemunhais, a análise da injustiça epistêmica permite afirmar que a dimensão hermenêutica está também presente nestes cenários de diálogo e interação. Fricker deixa isto claro ao levantar a questão dos estilos narrativos esperados, afirmando que "um gap hermenêutico pode dizer respeito não somente ao conteúdo, mas também à forma daquilo que pode ser dito" (Fricker, 2007, p.160). Assim, podemos 
ver como os estilos narrativos empregados pelo testemunho constituem um aspecto importante também para a dimensão hermenêutica da injustiça, uma vez que membros de determinados grupos sociais podem ter sua credibilidade diminuída em função das formas de se expressarem. Quando os solicitantes ou refugiados se comunicam, então, a partir de uma voz distinta daquela esperada pelos membros de grupos em situação vantajosa de poder há a potencialidade de reproduções de injustiça também em sentido hermenêutico. Veremos, no decorrer da tese, que ainda que haja uma predominância do aspecto testemunhal da injustiça epistêmica na análise dos processos de elegibilidade, há também a indicação de co-existência de um tipo hermenêutico da injustiça, que será discutido em maiores detalhes no último capítulo.

Há não somente uma generalização sobre determinados grupos sociais (mulheres refugiadas que tenham sofrido violência como emotivas, por exemplo) que produz expectativas não razoáveis sobre um sujeito, mas também um préjulgamento sobre como alguém que viveu determinada experiência deve se comportar. Este cenário destaca o caráter essencialmente epistêmico da injustiça produzida, uma vez que há um obstáculo significativo na transmissão de conhecimento: um sujeito é impedido de transmitir conhecimento a partir de suas próprias experiências sociais. Conforme vimos no decorrer da discussão, são as experiências dos oficiais de elegibilidade que costumam orientar os julgamentos de credibilidade, produzindo compromissos cognitivos com uma generalização feita a partir das percepções pessoais dos sujeitos que julgam. Não há espaço, assim, para uma produção de conhecimento a partir dos próprios refugiados sobre situações políticas e sociais complexas que foram vivenciadas em seus países de origem. Aquilo que não é considerado plausível, muitas vezes por trazer junto um grau de violência inimaginável para pessoas que vivam em relativa paz, simplesmente não aconteceu ou não poderia vir a acontecer. A dimensão da plausibilidade acompanha, assim, os julgamentos sobre o caráter crível dos sujeitos e seus testemunhos, trazendo a relevância das expectativas sobre os estilos narrativos e os tipos de histórias esperadas no universo do refúgio, como veremos nas dinâmicas das análises de credibilidade realizadas no Brasil.

A irrelevância da experiência social do refugiado para os processos de refúgio também é fortalecida se levarmos em consideração a dimensão da consistência externa que abordei anteriormente. A necessidade de informações 
sobre os países de origem dos solicitantes é satisfeita a partir da figura do expert ou do pesquisador encarregado de procurar notícias e relatórios sobre os diferentes cenários sócio-políticos. O refugiado nunca é chamado, assim, a contribuir com uma produção de conhecimento sobre seu país de origem, ficando a cargo de uma terceira pessoa o desenvolvimento de todo um campo de saber em torno de diferentes localidades, grupos sociais e experiências políticas.

Este quadro guarda relação com o processo de silenciamento de sujeitos ao qual se referiu Fricker ao analisar formas de exclusão operadas pela injustiça epistêmica testemunhal. Sob esta perspectiva, os membros de grupos sociais que estão sujeitos a preconceitos identitários também "não serão pedidos a compartilhar seus pensamentos, julgamentos e opiniões" (Fricker, 2007, p.130). Haveria, então, o esvaziamento da importância de uma determinada troca testemunhal, fazendo com que não seja necessário o diálogo com o sujeito refugiado, cuja narrativa não é solicitada para compreensão do contexto do qual fugiu em seu país de origem. Mesmo que tenha sido reconhecido como refugiado e, portanto, considerado crível para recebimento do status, este sujeito ainda sofre de um esvaziamento de credibilidade que o impede de ser considerado um ator epistêmico importante, conforme veremos em detalhes nos próximos capítulos.

Ainda que seja um refugiado reconhecido, ele permanece privado da possibilidade de contribuir para o conhecimento coletivo a partir de sua própria perspectiva e experiência social. Este quadro chama a atenção não somente para a dimensão ética ${ }^{18}$ de uma injustiça testemunhal, uma vez que há uma objetificação e des-humanização do refugiado, mas também para o fato de que a credibilidade não é algo restrito ao processo de determinação de status. Vemos, assim, que o julgamento de credibilidade acompanha o sujeito ao longo de sua condição refugiada e não apenas durante os meandros burocráticos de um processo de concessão do estatuto. Conforme discutimos anteriormente, a questão da confiança emerge como central na vida dos refugiados e está intrinsecamente conectada aos déficits de credibilidade que este sujeito experimenta ao longo de sua condição

\footnotetext{
${ }^{18}$ Conforme vimos anteriormente com Fricker, há um processo de objetificação do outro, excluído da possibilidade de exercer uma posição de sujeito do conhecimento, fazendo com que haja não só uma dimensão epistêmica nesta injustiça, mas também ética, uma vez que impacta uma prática fundamental em termos de valoração humana.
} 
sócio-política. A própria experiência do refúgio coloca a confiança em julgamento, substituindo-a por uma desconfiança persistente (Daniel e Knudsen, 1995).

Neste cenário, desconfia-se não somente da autenticidade de uma solicitação de refúgio, mas também do valor do refugiado enquanto um participante ativo nas práticas de produção de significados sociais a partir de suas próprias experiências, perspectivas e entendimentos. A ausência da participação dos sujeitos na produção de significados sobre - e a partir de - sua própria experiência social ressalta o caráter hermenêutico da injustiça epistêmica que, embora se manifeste em trocas testemunhais, pode estar mais evidente no cenário amplo de marginalização hermenêutica. Com isso em mente, analisaremos no capítulo final da tese a representação midiática brasileira sobre o refugiado e a possibilidade de uma injustiça hermenêutica na produção de significados sobre a experiência do refúgio.

Veremos, assim, que é possível identificar um cenário estrutural mais amplo no qual as injustiças em relação aos refugiados se reproduzem, ressaltando o caráter sistemático proveniente das desigualdades estruturais de poder. Conforme tratei ao longo do capítulo, há uma condição dormente de injustiça que acaba vindo à tona em momentos de interação nos quais um sujeito busca tornar sua experiência inteligível por meio do testemunho. Isso não significa, porém, que a injustiça esteja restrita ao espaço da troca testemunhal, mas evidencia que há uma dupla forma de injustiça posta em operação tanto pelo preconceito em julgamentos de credibilidade quanto por preconceitos estruturais nos recursos hermenêuticos coletivos. Buscarei refletir, dessa maneira, sobre a baixa inteligibilidade que atravessa a experiência do refúgio no cenário brasileiro para além dos processos de elegibilidade, tendo em mente a produção de significados atribuídos pela mídia aos refugiados.

Os sujeitos que buscam refúgio encontram dificuldades em tornar inteligível, através das trocas testemunhais, uma experiência relevante para sua existência. Além disso, tanto os solicitantes quanto os refugiados encontram obstáculos para sua efetiva participação na produção de conhecimento, muitas vezes percebidos como irrelevantes na geração de significados sociais. Neste cenário, parece insuficiente uma crítica voltada apenas à melhoria dos julgamentos de credibilidade. Conforme pudemos refletir com Butler, a própria impossibilidade de um projeto auto-narrativo totalmente coerente põe em questionamento a adequação da credibilidade como elemento central para determinar a identidade de 
um sujeito. A incoerência que marca qualquer tentativa de uma narrativa de si mesmo gera, por si só, um problema fundamental nos critérios adotados para determinação do status de refugiado, como vimos no debate sobre os processos de elegibilidade.

Nesse sentido, não se trata apenas de uma crítica que, como o faz Fricker, proponha uma nova postura de virtude e justiça nas trocas testemunhais, mas sim de uma que ressalte a própria inadequação de uma "economia de credibilidade" no centro dos processos de refúgio. Em seu lugar, uma posição ética e virtuosa no encontro entre o eu e o outro, que a condição refugiada pressupõe, deve levar em conta como nossas práticas epistêmicas estão ligadas a um exercício de poder que produz limites de inteligibilidade a um custo significativo sobre outras vidas.

Uma análise situada a partir do caso brasileiro será desenvolvida nos próximos capítulos a fim de que seja possível dar continuidade à reflexão do refúgio como um espaço de reprodução de formas de injustiça testemunhal e hermenêutica. Não estarei focada apenas em uma "economia da credibilidade", embora esta ocupe lugar central nas análises, mas me deterei também sobre os diferentes significados produzidos pela mídia sobre os refugiados. Espero que seja possível questionar, a partir disso, os regimes de visibilidade e produção de conhecimento que são construídos como espaços possíveis de habitação para os sujeitos em situação de refúgio e sua relação possível com formas de injustiça epistêmica.

\section{5 Conclusões}

O esforço empreendido neste capítulo inicial pretendeu a apresentação e o detalhamento da abordagem teórica que serve de base às análises produzidas pela tese. Busquei não somente explorar o conceito teórico-filosófico da injustiça epistêmica, conforme desenvolvido por Miranda Fricker, mas também abordar algumas das principais discussões e críticas nesse campo, especialmente no que diz respeito às possibilidades de uma injustiça do tipo testemunhal. Nesse sentido, revelou-se fundamental desenvolver alguns conceitos que permeiam o debate, como a idéia de uma economia de credibilidade, a relação entre excessos e déficits de credibilidade, os privilégios epistêmicos e as práticas de silenciamento, que atravessam as análises dos autores que dialogam com a abordagem da injustiça 
epistêmica. Apesar da centralidade que a dimensão testemunhal da injustiça ocupa não somente na perspectiva de Fricker, mas também nos debates do campo e, ainda, nesta tese, procurei explorar também em detalhes as contribuições a respeito da dimensão hermenêutica da injustiça. Vimos, assim, a interligação entre os dois casos exemplares de injustiça epistêmica, bem como o esforço de contextualização em termos de poder social, preconceitos estruturais e marginalizações que afetam os chamados recursos hermenêuticos coletivos e, com isso, a vida de determinados sujeitos.

Embora a ênfase deste capítulo tenha recaído sobre a abordagem da injustiça epistêmica, e o campo de debates em torno da mesma, também procurei inserir contribuições pontuais de autores como Butler e Foucault a fim de propor um afastamento da perspectiva sobre as soluções ao quadro de injustiça delineado pela obra de Fricker. Busquei salientar, assim, que não se trata apenas de reformar as disfunções em uma economia da credibilidade para superar a injustiça epistêmica, chamando a atenção para as impossibilidades existentes no próprio projeto de julgar a credibilidade de sujeitos e buscar uma verdade coerente em suas narrativas. O contato com a crítica desenvolvida por Butler permitiria, nesse sentido, entender a complexidade imiscuída em todo e qualquer esforço autonarrativo e na inteligibilidade do encontro entre o eu e o outro. A própria perspectiva da autora também trouxe a relevância dos questionamentos foucaultianos a respeito da dimensão estrutural na qual o encontro acontece, trazendo à tona a necessidade de repensar as relações entre nossas práticas epistêmicas e um determinado regime de verdade.

Seria preciso, então, não somente refletir sobre uma dimensão individual do encontro e da troca testemunhal entre sujeitos, mas também levar em consideração um debate mais amplo sobre os termos estruturais que orientam processos de interpelação e reconhecimento. Conforme vimos, ainda que Fricker considere a relevância da dinâmica estrutural, suas análises a respeito de uma virtude da justiça epistêmica ainda permanecem em grande medida restritas a propostas de ajustes individuais.

A segunda parte deste capítulo buscou abrir caminho para pensarmos a questão do refúgio à luz da discussão teórica proposta aqui, especialmente a partir do papel central concedido à credibilidade nos processos de determinação do status de refugiado. Assim, a existência de uma economia da credibilidade nos centros 
dos processos de refúgio permite tecer paralelos importantes com as discussões sobre a possibilidade de manifestação de uma injustiça testemunhal nos espaços de troca e interação com solicitantes de refúgio e refugiados. Apesar da ênfase sobre as dinâmicas testemunhais e as avaliações das narrativas dos sujeitos em processos de elegibilidade, no Brasil e no mundo, também busquei identificar um cenário estrutural mais amplo no qual as injustiças podem se reproduzir, ressaltando as desigualdades estruturais de poder. Nesse sentido, considerei importante ressaltar as dificuldades que refugiados e solicitantes podem ter em tornar inteligível determinadas experiências, assim como em participar ativamente na produção de conhecimento e significados sociais.

Tendo em mente as análises desenvolvidas até aqui, os próximos capítulos irão buscar discutir a questão da injustiça epistêmica no universo do refúgio a partir do cenário brasileiro. $\mathrm{O}$ segundo e o terceiro capítulo propõem uma reflexão detalhada sobre o processo de refúgio no Brasil, e a produção epistêmica de sujeitos pelo sistema, a partir das entrevistas realizadas com diversos atores que compõem este campo de relações. A partir das falas dos entrevistados, irei analisar as dinâmicas do processo de elegibilidade e sua relação com um quadro de injustiça epistêmica, especialmente em sua dimensão testemunhal. Buscarei refletir, assim, sobre alguns dos principais espaços de troca entre solicitantes de refúgio e atores das instituições que compõem a estrutura do processo decisório, como as entrevistas de elegibilidade e as práticas de preenchimento dos formulários de solicitação de refúgio. Também procurarei abordar os próprios espaços de debate e decisão entre os atores responsáveis por decidir sobre os casos de refúgio, trazendo à tona diferentes perspectivas e papeis desempenhados a fim de julgar a credibilidade dos sujeitos. Embora ambos os capítulos tratem de tais dinâmicas, sua escrita foi feita de modo a lançar luz sobre as nuances do processo e as percepções diversas dos atores envolvidos, inclusive os próprios solicitantes e refugiados.

Por último, o quarto capítulo irá se debruçar sobre práticas de representação midiática sobre os refugiados no Brasil, bem como de participação desses sujeitos no processo de gerar significados a respeito de sua própria experiência social. Com esta análise, pretendo compreender como obstáculos à inteligibilidade sobre o refúgio não se restringem aos processos burocráticos e a uma economia da credibilidade, mas compõem uma estrutura social mais ampla que traz a 
possibilidade de uma marginalização hermenêutica que reproduz um quadro de injustiça epistêmica. 


\section{3 \\ As práticas do refúgio por elegibilidade no Brasil: Burocracia e injustiça epistêmica}

\section{Resumo}

O presente capítulo tem como objetivo abordar o chamado processo brasileiro de elegibilidade por meio do qual é operada a determinação do status de refugiado no Brasil. Parto de uma exposição introdutória do refúgio por elegibilidade no país a fim de que seja possível analisar detalhadamente, no decorrer do texto, o processo de formação da burocracia de determinação do status. As análises são realizadas com base em um conjunto de entrevistas conduzidas durante a pesquisa de campo, as quais podem ajudar a compreender as múltiplas perspectivas dos atores envolvidos no processo de elegibilidade no país. As falas de diversos refugiados, solicitantes de refúgio, funcionários e voluntários de instituições do Rio de Janeiro, São Paulo e Brasília são trazidas para a pesquisa de modo a compor o material da análise sobre as condições de possibilidade de produção de uma injustiça epistêmica no refúgio por elegibilidade.

Palavras-chave: Elegibilidade; Burocracia; Injustiça Epistêmica.

\section{1 Introdução}

Diversas pesquisas etnográficas sobre tribos ou sociedades isoladas no interior do território brasileiro já foram realizadas por antropólogos, porém "poucas tentativas foram feitas no sentido de penetrar a intimidade da vida nas tribos muito mais próximas" (Latour e Woolgar, 1986, p.17). Embora Latour e Woolgar estejam se referindo nesse estudo às tribos de cientistas e à produção da ciência em seus laboratórios, considero apropriado utilizar a perspectiva dos autores para tratar das tribos dos funcionários/voluntários de organizações humanitárias e governamentais que atuam no processo de refúgio no Brasil. Assim, apesar da importância dessas organizações e seus atores nas decisões referentes à concessão do status de refugiado, poucos estudos têm sido feitos de modo a dar conta dos detalhes das atividades diárias dessas tribos. Minha escolha desses locais de rica vida política e social tem como objetivo utilizar a familiaridade e proximidade a fim de produzir um estudo situado que possa servir como inspiração para análises posteriores 
também interessadas em produzir conhecimento sobre tribos cujos rituais podem ser menos "exóticos", porém com importantes efeitos sobre nossa sociedade.

Em etnografias de organizações, "a observação participante significa que o pesquisador assume o papel de um membro da organização ou, alternativamente, um empregado se torna um pesquisador" (Czarniawska, 2007, p.13). Embora a realização deste e do próximo capítulo tenha sido feita com base na produção de uma série de entrevistas, e não a partir de um estudo etnográfico por meio da observação participante, considero fundamental apontar abertamente aqui meu engajamento inicial no campo, responsável por uma parte significativa do meu conhecimento sobre o processo de refúgio no Brasil e dos meus contatos com seus principais atores e instituições. Como voluntária em uma organização nãogovernamental que representa a sociedade civil nos processos decisórios no campo do refúgio, chamada Cáritas-Rio, eu considero minha posição inicial mais próxima àquela de uma funcionária que posteriormente se torna pesquisadora. Ainda que a realização das entrevistas tenha ocorrido somente após minha saída da Cáritas-Rio, os dois anos em que trabalhei de forma voluntária no setor de proteção legal e elegibilidade da instituição me possibilitaram estabelecer não só uma rede de contatos, mas também me ajudaram a compor alguns dos questionamentos relacionados ao refúgio por elegibilidade no país.

Meu prolongamento em uma instituição importante no campo do refúgio, a minha presença em reuniões formais e informais, bem como meu apoio às lutas diárias de refugiados, solicitantes e funcionários ajudaram a desenvolver um tipo de relação marcada pelo engajamento e pela confiança que, por sua vez, facilitou as renegociações da minha posição, do meu acesso e da condução da minha pesquisa após a saída da Cáritas-Rio. A saída do campo e a escrita deste capítulo me permitiram racionalizar esse processo e construí-lo de maneira ordenada $a$ posteriori para o leitor. Na prática, porém, a minha atuação no campo como voluntária engajada e os benefícios que desfruto desse engajamento agora, como pesquisadora, são desordenados e caóticos. De forma geral, considero importante partir desse cenário a fim de expor seus impactos sobre a condução destes capítulos de inspiração etnográfica, principalmente no que diz respeito à possibilidade de acesso aos atores e às instituições que se tornaram mais familiares após minha atuação inicial no campo. Não só aqueles que já me conheciam estavam mais 
dispostos a serem entrevistados por mim posteriormente, como também pude mobilizar minhas conexões anteriores para conseguir novos acessos.

A minha inserção voluntária inicial no setor de proteção legal e elegibilidade da Cáritas-Rio também trouxe uma questão fundamental a ser considerada aqui: a necessidade do chamado estranhamento antropológico. Para Latour e Woolgar (1986), é necessário quebrar a familiaridade do observador com o seu objeto (e sujeito) de estudo e assumir algum tipo de estranhamento ou, nos termos dos autores, apreender como estranhos aqueles aspectos da atividade científica que são tomados como garantidos, que já são dados ou vistos pelo observador a partir da perspectiva da familiaridade. Os autores alertam, assim, para os "perigos de se tornar nativo" (idem, p.29), expondo sua preocupação com não tomar como garantida, ou dada, a forma de atuação dos cientistas em seus laboratórios. Tendo isso em mente, a manutenção do estranhamento diante dos processos de refúgio emergiu como um desafio para a condução das entrevistas. Assim, após o meu distanciamento do campo e o início das minhas atividades de pesquisadora, foi necessário retomar uma predisposição ao estranhamento, questionando algumas práticas que antes eram familiares para mim, como, por exemplo, o preenchimento do formulário de solicitação de refúgio, o discurso oficial sobre casos "fortes" e casos "fracos" e as referências constantes à credibilidade dos solicitantes de refúgio.

As entrevistas conduzidas precisaram, ao mesmo tempo, partir de um estranhamento do processo a fim de que os atores pudessem retomá-lo em detalhes a partir de suas próprias perspectivas, mas também contar com um conhecimento prévio do funcionamento desse sistema de refúgio, buscando responder algumas inquietações específicas já levantadas. Nesse sentido, o início do presente capítulo será composto por uma breve exposição introdutória do chamado processo brasileiro de elegibilidade, realizada tanto a partir das entrevistas, quanto a partir da minha compreensão do assunto. Buscarei recontar, em linhas gerais, as práticas de determinação do status de refugiado no país, situando seus principais atores e instituições em um quadro mais amplo para o entendimento da leitora.

Em seguida, analisarei o ritual de preenchimento do formulário de solicitação de refúgio, trazendo contribuições pontuais a respeito do formato e do estilo das narrativas vistas como adequadas ao processo de elegibilidade. Neste cenário, emerge como crucial refletir sobre as condições de possibilidade para a circulação das idéias dos solicitantes de refúgio e a existência de práticas de 
restrição ao seu conhecimento. Buscarei analisar, assim, um quadro complexo de interação que faz com que os sujeitos se vejam obrigados a não só fazer sentido de suas próprias experiências sociais, mas também encaixá-las na linguagem burocrática do processo. A discussão também não irá prescindir de uma abordagem crítica a respeito dos preconceitos direcionados à competência dos solicitantes de refúgio nesta etapa inicial.

Após a análise do ritual de preenchimento dos formulários, buscarei refletir sobre a etapa das entrevistas com os solicitantes de refúgio, contribuindo para o debate sobre esta prática marcada pela imagem investigativa de "extrair informações", "mapear" e "penetrar" os solicitantes de refúgio, afastando-se da perspectiva da troca testemunhal para transmissão de conhecimento. Buscarei analisar, ainda, a relação existente neste contexto entre déficits e excessos de credibilidade, o privilégio epistêmico ${ }^{19}$ do oficial de elegibilidade e a busca por apagar sua presença nas práticas que determinam se o solicitante é ou não um sujeito crível. Também levantarei a existência de uma concepção ambígua a respeito da confiança: o solicitante de refúgio precisaria confiar no oficial e em outros funcionários das instituições encarregadas do processo de elegibilidade, ao mesmo tempo em que necessitaria lidar com a desconfiança desses atores em relação a sua figura.

As duas últimas seções do capítulo estarão voltadas para o debate acerca da credibilidade dos solicitantes de refúgio. Primeiro, buscarei me deter sobre as perspectivas existentes a respeito da força ou fraqueza das solicitações. Nesse sentido, a análise estará voltada para a tentativa de compreensão dos critérios que desempenham papel central nas avaliações sobre os solicitantes e seus testemunhos, transitando pelas discussões sobre a importância atribuída ao detalhamento das narrativas e sua plausibilidade, bem como ao comportamento e à nacionalidade dos sujeitos. A contribuição que busco fazer aqui está relacionada ao debate sobre preconceitos e estereótipos em relação aos solicitantes, bem como a presença de um etnocentrismo que ressalta não apenas a dimensão testemunhal da injustiça epistêmica, como também sua dimensão hermenêutica. Por fim, irei discutir o espaço do Grupo de Estudos Prévios (GEP) e o privilégio epistêmico atribuído aos

\footnotetext{
${ }^{19}$ De acordo com o já exposto no primeiro capítulo, utilizo o termo "privilégio epistêmico" na tese em sintonia com a perspectiva desenvolvida por Medina (2011), isto é, como um excesso de credibilidade não-merecido.
} 
chamados "técnicos do refúgio", os obstáculos à participação dos solicitantes e refugiados, bem como a possibilidade de operação de uma injustiça epistêmica testemunhal e hermenêutica.

A análise das transcrições das entrevistas será organizada, assim, de modo a compor um material que permita o detalhamento de algumas das práticas centrais do refúgio por elegibilidade no país, sem deixar de ter como fio condutor a discussão teórica que atravessa meu olhar nesta tese e que levanta a possibilidade de operação de um tipo essencialmente epistêmico de injustiça. Busco realizar aqui uma análise que enfatiza o processo de formação da burocracia da elegibilidade, ressaltando aspectos do ritual de preenchimento do formulário de solicitação de refúgio, das narrativas e entrevistas oficiais com os solicitantes, das análises de credibilidade e das discussões "técnicas" sobre as solicitações de refúgio. O olhar neste capítulo é direcionado, então, a como o processo de determinação do status de refugiado é percebido pelos diversos atores e construído do ponto de vista formal.

De maneira geral, e a partir das análises desenvolvidas neste capítulo, é possível observar a existência não somente de um privilégio epistêmico de determinados atores, como também a relação fundamental entre déficits e excessos de credibilidade no processo de determinação da condição refugiada. Deste quadro vemos emergir noções etnocêntricas, bem como estereótipos e preconceitos acerca da competência dos solicitantes de refúgio, fazendo com que haja uma série de obstáculos à transmissão do conhecimento destes sujeitos, cada vez mais marginalizados e excluídos do processo de elegibilidade enquanto sujeitos de conhecimento. Mais do que isso, é possível refletir aqui sobre a dimensão hermenêutica da injustiça epistêmica que pode se manifestar nas trocas testemunhais (Fricker, 2007), especialmente quando nos deparamos com a ausência de inteligibilidade sobre as experiências sociais dos solicitantes de refúgio e da participação destes sujeitos no processo.

Todas as diferentes etapas que busco analisar aqui, o ritual de preenchimento do formulário, as entrevistas de elegibilidade, as análises de credibilidade e os debates no GEP, possuem dois pontos em comum fundamentais nas dinâmicas da injustiça epistêmica. Em primeiro lugar, é possível observar um gradual desaparecimento do solicitante de refúgio no processo de elegibilidade, com a desapropriação das narrativas. Vemos não só a transformação da vida em 
documento, no ritual do formulário de refúgio, como também um papel proeminente atribuído à expertise dos "técnicos do refúgio", responsáveis por julgar a credibilidade, determinar a força e a fraqueza dos casos e tomar decisões. Dessa maneira, e conforme nos diz Fricker (2007), é possível perceber a manifestação de uma injustiça hermenêutica nas trocas testemunhais - aqui menos na dimensão da capacidade de fazer sentido das próprias experiências sociais e mais na dimensão da participação dos sujeitos na produção de significados e transmissão de conhecimento. Vemos, assim, a restrição ao conhecimento dos solicitantes e refugiados, bem como obstáculos a sua participação no processo de elegibilidade.

Em segundo lugar, é possível perceber o papel central de uma "economia da credibilidade" (Fricker, 2007) nas etapas analisadas, com a atuação de preconceitos e estereótipos que lançam luz não somente sobre o déficit de credibilidade atribuído ao solicitante de refúgio, mas também sobre a relação entre excessos e déficits de credibilidade. Tal quadro demonstra, então, como determinados sujeitos desfrutam de um privilégio epistêmico no processo, podendo contribuir para a produção de uma injustiça testemunhal no seio das práticas de credibilidade.

\section{2 \\ O processo brasileiro de elegibilidade}

O processo de elegibilidade pode ser compreendido como um conjunto de procedimentos voltados para a determinação da condição refugiada, isto é, para definir a concessão ou não do status de refugiado àqueles que o solicitam. O Alto Comissariado das Nações Unidas para os Refugiados (ACNUR) afirma que uma pessoa é um refugiado independentemente de ter sido reconhecida ou não por um processo de elegibilidade ${ }^{20}$. Em outras palavras, o discurso oficial do ACNUR estabelece que o processo de determinação de status não tem o objetivo de atribuir a condição refugiada a um sujeito, mas apenas de revelar ou descobrir tal condição no outro. O ACNUR determina, assim, que um sujeito não se torna refugiado porque é reconhecido como tal, mas é reconhecido como tal porque é um refugiado. Mais do que um simples jogo de palavras, é possível entender a perspectiva oficial

\footnotetext{
${ }^{20}$ Apesar da perspectiva institucional sobre a independência da condição refugiada em relação ao processo de elegibilidade, na prática, um sujeito precisa ter seu pedido de refúgio deferido a fim de que seja reconhecido como um refugiado e possa, então, ter acesso aos direitos (e deveres) relativos à sua condição.
} 
da organização como uma busca por reafirmar o processo de elegibilidade como mecanismo declaratório que seria fundamental para trazer à luz a condição ontológica do sujeito refugiado. Nesse sentido, a elegibilidade seria vista oficialmente como uma forma de busca da verdade sobre a ontologia refugiada dos sujeitos solicitantes.

Os marcos normativos internacionais no campo do refúgio, como a Convenção de 1951 e o Protocolo de 1967, não prescrevem os mecanismos para concessão do status de refugiado, ficando a cargo de cada Estado determinar seus próprios procedimentos para análise das solicitações de refúgio e determinação da condição refugiada (Alexander, 1999; Gorlick, 2002; Kagan, 2006). Mesmo dependente, em última instância, da organização procedimental de cada Estado, o processo de elegibilidade emerge como mecanismo central para a proteção do sujeito refugiado (Kagan, 2006), já que pode ser pensado como o meio através do qual aqueles que precisam de proteção são identificados (Alexander, 1999) ou produzidos (Facundo, 2017). No que diz respeito a sua importância nos meios de pesquisa e produção acadêmica, o processo de elegibilidade pode ser visto como crucial no entendimento da transformação do direito e da política em práticas (Alexander, 1999; Kagan, 2003; Rousseau et al., 2002; Saltsman, 2014). Assim, ainda que dependa da discricionariedade dos diferentes atores em diversas localidades e instituições, e talvez justamente por isso, a elegibilidade emerge como mecanismo fundamental para compreensão das práticas de determinação do status de refugiado.

No contexto brasileiro, a adoção da Lei 9.474, em 1997, foi responsável por elaborar a proteção nacional dos refugiados e, com isso, estabelecer oficialmente os procedimentos e critérios que passam a ser entendidos como o processo de elegibilidade. A lei também foi responsável por criar o Comitê Nacional para os Refugiados (CONARE) ${ }^{21}$, órgão multiministerial encarregado de reconhecer e tomar decisões sobre a condição refugiada no país. Antes do estabelecimento da lei, os procedimentos oficiais para a concessão do refúgio poderiam ser resumidos da

\footnotetext{
${ }^{21}$ Compõem o CONARE: Ministério da Justiça, que o preside; Ministério das Relações Exteriores, vice-presidência; Ministério do Trabalho e Emprego; Ministério da Saúde; Ministério da Educação; Departamento de Polícia Federal; Cáritas/RJ e Cáritas/SP como representantes da sociedade civil, titular e suplente, respectivamente; e o Alto Comissariado das Nações Unidas para Refugiados ou United Nations High Commission for Refugees (ACNUR/UNHCR), que possui direito a voz, sem voto. A Defensoria Pública da União tem status de membro consultivo perante o CONARE. O Instituto de Migrações e Direitos Humanos (IMDH) participa como membro observador.
} 
seguinte maneira: o escritório do ACNUR no país conduzia uma entrevista com o solicitante de refúgio e produzia um documento oficial recomendando ou não a concessão do refúgio; o documento era encaminhado ao Ministério das Relações Exteriores, que elaborava sua própria opinião ou recomendação sobre o caso, encaminhando-o para o Ministério da Justiça, responsável por proferir a decisão final (Jubilut, 2007). A adoção da lei 9.474 e a criação do CONARE permitiram um afastamento do modelo unidirecional anterior a fim de produzir um ambiente coletivo de discussões sobre a concessão do status de refugiado, criando alguns espaços de "estudo técnico" dos casos e de deliberação conjunta, conforme veremos a seguir.

O processo de elegibilidade no Brasil tem início a partir da entrada do sujeito no país e da formalização do seu pedido de refúgio perante um agente da Polícia Federal, responsável por lavrar um Termo de Declaração que traz as razões pelas quais o sujeito está solicitando refúgio, além dos seus dados pessoais básicos (Jubilut, 2007). O sujeito interessado em solicitar refúgio deve, então, preencher o formulário de solicitação de refúgio do CONARE, disponível no site da Polícia Federal em inglês, francês, espanhol e português ${ }^{22}$. Após o preenchimento, o solicitante deve ir até uma Unidade da Polícia Federal para formalizar o pedido. Conforme veremos melhor na próxima seção, o formulário é constituído por uma série de perguntas sobre a vida do solicitante, seus dados pessoais mais básicos, assim como sua história de perseguição e os motivos pelos quais deixou o país e resolveu solicitar refúgio no Brasil. O formulário preenchido passa a constituir, assim, parte fundamental do processo de elegibilidade, uma vez que as informações contidas no documento são constantemente relidas e avaliadas durante a tramitação do pedido de refúgio.

Embora seja possível ver, a partir do parágrafo anterior, a presença continuada da Polícia Federal no processo e a sua relação direta com o solicitante de refúgio e com o refugiado no país, quando questionado sobre a realização de algum treinamento para orientar o trabalho no campo do refúgio, Jorge me conta:

\footnotetext{
${ }^{22}$ Apesar de estar disponível na internet, é comum que o solicitante entre em contato com alguma organização da sociedade civil, como a Cáritas, antes de preencher o documento. Assim, muitos solicitantes passam a ser orientados por funcionários e voluntários de uma organização nãogovernamental a fim de que compreendam a linguagem burocrática e a importância do preenchimento correto do formulário. Cabe ressaltar, ainda, a transformação ocorrida em 2019, e posteriormente à escrita deste capítulo, no formato do formulário, que passa a ser preenchido online.
} 
Ah qual é o treinamento? Aqui é polícia né?! Treinamento tem que ter lá fora. A gente trabalha com a lei né, e com a educação, a PF tem um nível intelectual e social que compreende situações, não tem truculência aqui, não tem falta de educação de polidez, aqui a gente trata com polidez, com humanidade, com carinho, mas é a lei que norteia a decisão, não tem como sair disso (Jorge, Polícia Federal, grifo meu).

Quando questionei, logo em seguida, o conhecimento da lei 9.474 por parte da Polícia Federal, Jorge me respondeu que tal legislação não interessa à instituição:

A lei do refúgio, até aonde ela tem direito, pelo menos a espinha dorsal, não interessa pra gente, já são coisas após o protocolo. Qual é a formalidade da polícia: saber se a é a, b é b, identificar, formalizar corretamente a documentação, checar o que vem de fora para dentro e encaminhar aos órgãos que faz a parte do serviço social, não compete mais a gente. Concorda comigo, dona Flávia?! ${ }^{23}$ (Jorge, Polícia Federal, grifo meu).

Após os contatos iniciais com a Polícia Federal, e a formalização do pedido de refúgio através do preenchimento do formulário, o solicitante deve passar por uma entrevista com um oficial de elegibilidade do CONARE. A entrevista constitui parte essencial do processo, uma vez que está em análise a credibilidade do solicitante de refúgio, tema que tratarei mais detalhadamente no decorrer do capítulo. Aquilo que foi escrito no formulário de solicitação de refúgio ajuda a dar base à preparação do oficial de elegibilidade para o momento da entrevista, com a utilização do documento como meio não só de orientar o oficial em relação ao caso do solicitante (quem é, de onde veio, quais as alegações sobre o temor de perseguição), mas também como forma de contrapor o que foi escrito com o que é narrado posteriormente.

Conforme me contou Simone, uma oficial de elegibilidade do CONARE, o ritual da entrevista passa por uma apresentação inicial a fim de explicar o processo de determinação de status para o solicitante e afirmar a confidencialidade e sigilo. Após a apresentação, há uma série de perguntas sobre o perfil do solicitante, com suas informações pessoais básicas e, por último, um questionamento direcionado aos motivos de saída do país de origem ou residência habitual e razões para a solicitação de refúgio. Embora a entrevista com um oficial de elegibilidade do CONARE seja a única entrevista oficial do processo, cabe mencionar aqui a

\footnotetext{
${ }^{23}$ Interpretei a pergunta como retórica e, portanto, não busquei respondê-la ou contestar a perspectiva do entrevistado.
} 
possibilidade de realização de entrevistas com outros atores do sistema, como, por exemplo, a Cáritas e o IMDH. A partir disso, as instituições da sociedade civil podem produzir suas próprias opiniões e recomendações sobre cada solicitação de refúgio, levando-as aos espaços coletivos de discussão. Entretanto, também não posso deixar de ressaltar que as entrevistas com instituições da sociedade civil não possuem a mesma importância que a entrevista oficial, relatada anteriormente - é a partir desta que é produzido um parecer recomendando o deferimento ou indeferimento da solicitação de refúgio.

O chamado parecer de elegibilidade do CONARE é produzido, então, pela presidência do órgão, ou seja, pelo Ministério da Justiça, sendo baseado em um arcabouço normativo que constitui a chamada análise de credibilidade, sobre a qual falarei no decorrer do capítulo. As opiniões dos membros do CONARE são debatidas e contrastadas no chamado Grupo de Estudos Prévios (GEP) ${ }^{24}$, o qual é caracterizado por alguns de seus participantes, como a Defensoria Pública da União (DPU), como um espaço para discussões técnicas sobre os casos. Os posicionamentos diversos no grupo, após discussão conjunta, são normalmente encaminhados para os atores que estarão presentes oficialmente na reunião do plenário do CONARE, quando há uma decisão final pronunciada em relação ao deferimento ou indeferimento dos casos pautados e discutidos nas reuniões. Cabe ressaltar, porém, que nem sempre os posicionamentos finais do GEP são mantidos na plenária, uma vez que os sujeitos que participam das reuniões representando cada instituição não são os mesmos, com exceção do representante da DPU (que não possui direito ao voto). Em outras palavras, não é, por exemplo, o advogado da Cáritas-Rio, presente no GEP, que participa do plenário do CONARE, mas sim o diretor da instituição. A fim de prover uma melhor compreensão do processo brasileiro de elegibilidade, destaco aqui dois diagramas de fluxo elaborados por $\operatorname{mim}$ :

\footnotetext{
${ }^{24} \mathrm{O}$ Grupo de Estudos Prévios (GEP) é um ambiente coletivo não obrigatório, mas que acontece regularmente, antes das reuniões Plenárias, sendo essas responsáveis pela decisão formal dos casos. O GEP é composto por todos os membros do CONARE que desejarem dele participar, mas, em geral, participam representantes do Ministério da Justiça, do Ministério das Relações Exteriores, da Polícia Federal, da Sociedade Civil organizada, além de membros observadores e consultivos, como o Instituto Migrações e Direitos Humanos, o ACNUR e a DPU.
} 
Diagrama 1: Processo de Solicitação de Refúgio

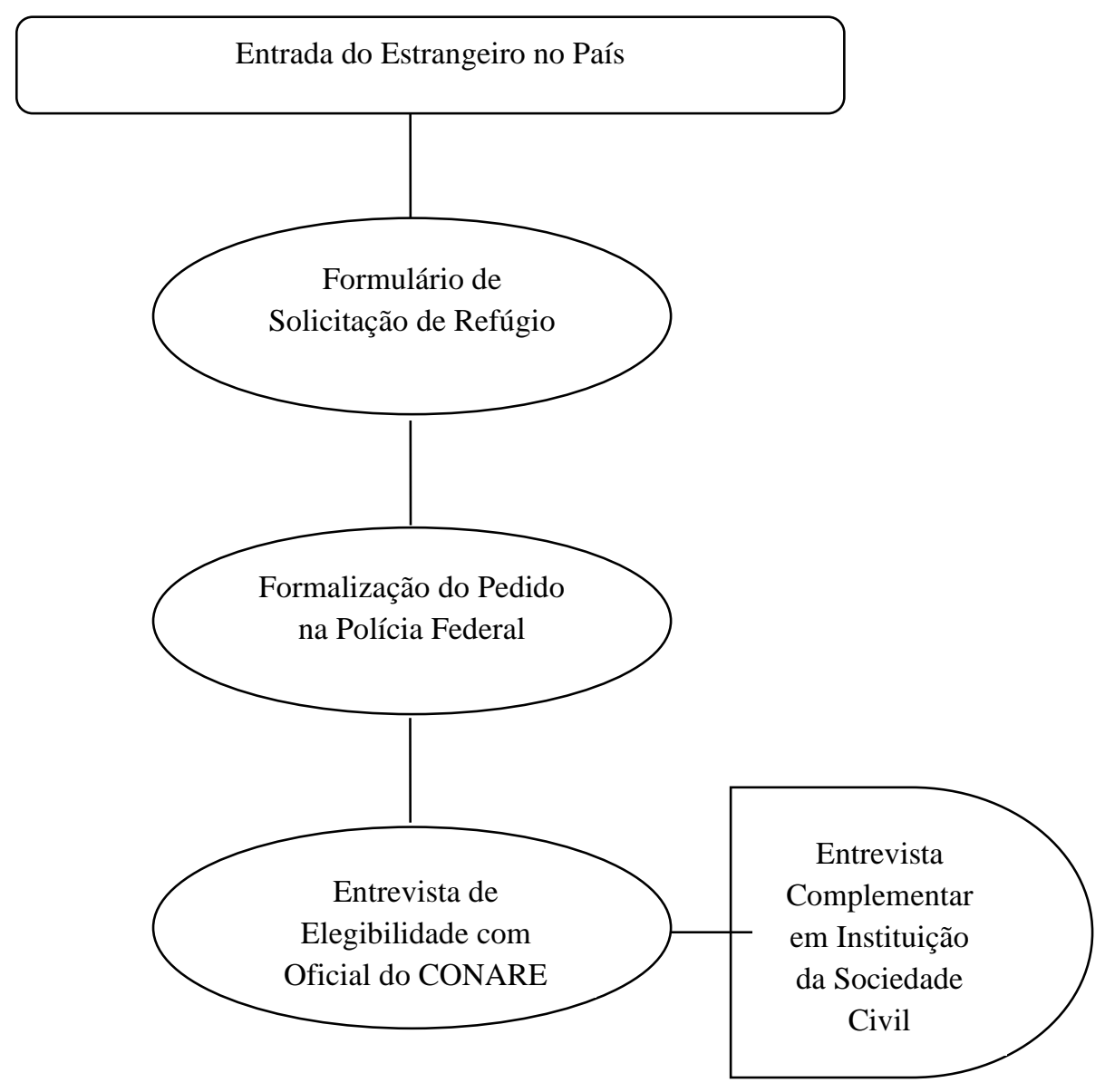


Diagrama 2: Processo Decisório

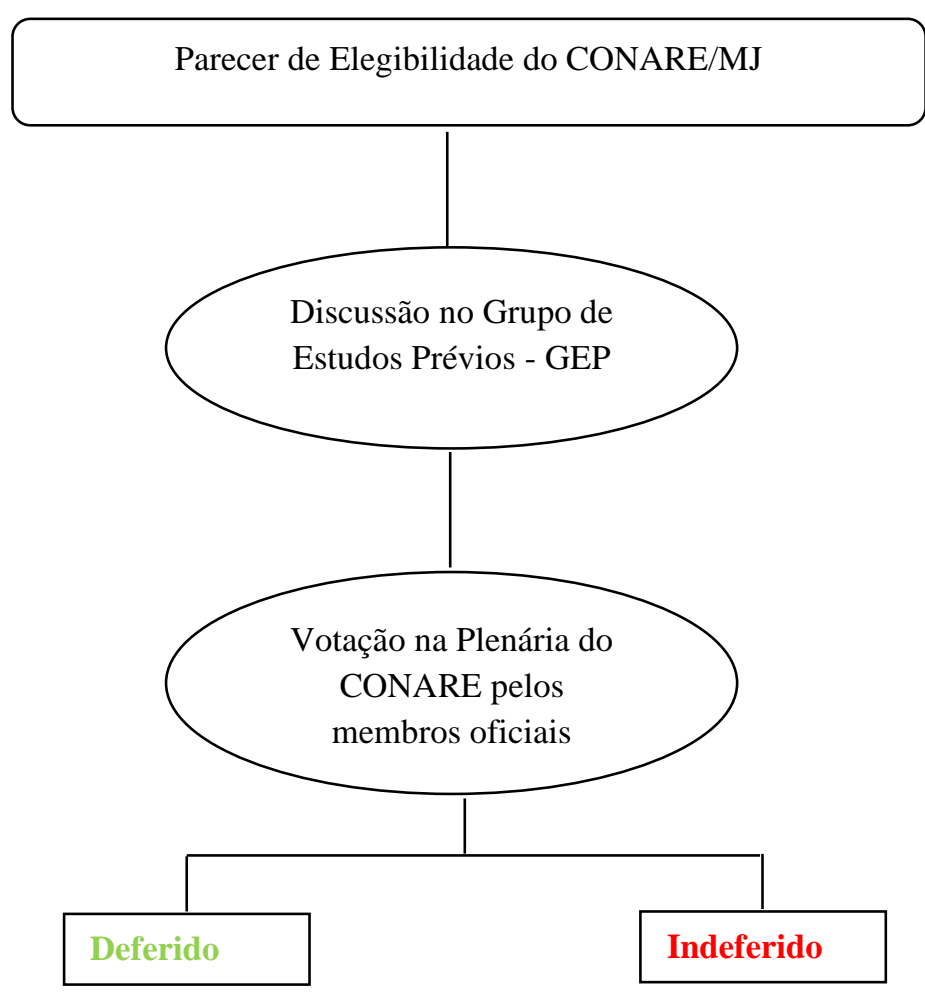

O panorama geral e introdutório do refúgio por elegibilidade no Brasil ajudanos a compreender minimamente o quadro das práticas, dos espaços e dos atores que constituem o processo de determinação da condição refugiada. A introdução ao tema da elegibilidade permite, assim, vislumbrar como organizações da sociedade civil, instituições governamentais e organismos internacionais se reúnem, se dividem e se sobrepõem nas várias etapas responsáveis pela concessão do status de refugiado. Por ser um debate que, conforme nos diz Saltsman (2014), ressalta a transformação da lei e da política em práticas, há uma significativa importância das análises sobre o processo de elegibilidade desde uma perspectiva situada e local. Nesse sentido, parece fundamental me deter sobre o tema em questão, trazendo de forma mais acentuada as diversas visões, posicionamentos e falas dos atores envolvidos no universo institucional brasileiro do refúgio por elegibilidade. Buscarei analisar, então, como o direito de refúgio, em sua política de concessão através das práticas de elegibilidade, encontra a dimensão epistêmica das trocas testemunhais - e o que isso pode significar em termos de produção de injustiça. 


\section{3 \\ O ritual de preenchimento do formulário}

A escolha por iniciar a análise do processo brasileiro de elegibilidade a partir dos rituais de preenchimento do formulário de solicitação de refúgio não é aleatória: não somente muitos entrevistados se referiram em suas falas à importância do documento, como também esta prática me chamou a atenção durante meu trabalho voluntário na Cáritas-Rio. Nesse sentido, minha própria experiência pessoal no campo se mistura aos relatos posteriores obtidos nas entrevistas, trazendo à tona a relevância de me deter sobre esta prática que dá início ao processo de elegibilidade. Em termos da importância deste ritual no contexto da discussão proposta neste trabalho, cabe destacar aqui que realizarei algumas contribuições específicas acerca do formato e estilo das narrativas que seriam vistos como adequados ao processo. Busco refletir, assim, sobre as condições de possibilidade para a circulação das idéias dos sujeitos e a existência de práticas de restrição ao seu conhecimento, dentro de um quadro complexo que demanda que os solicitantes de refúgio não só façam sentido de suas próprias experiências, como também as encaixem na linguagem burocrática do processo. A análise também é atravessada pela discussão sobre a existência de preconceitos em relação à competência dos solicitantes nesta etapa inicial do refúgio por elegibilidade.

Já emerge, dos rituais de preenchimento do formulário, o privilégio epistêmico de alguns atores responsáveis por determinar quais estilos de narrativa, formas de evidência e modos de compartilhar o conhecimento podem ser adequados para o processo de refúgio. Em termos de uma "economia da credibilidade", expressão desenvolvida por Fricker (2007) e abordada no primeiro capítulo, o que vemos neste estágio inicial é a manifestação de preconceitos em relação à competência dos solicitantes de refúgio, vistos como ignorantes ou estúpidos (Anderson, 2012). Assim, ainda que não seja possível falar sobre a atribuição de déficits de credibilidade ao que o solicitante narra, é possível observar, nos termos propostos por Hookway (2010), uma injustiça epistêmica relacionada à recusa em levar a sério a habilidade do sujeito em prover conhecimento relevante nesta etapa do processo. Haveria, nesse sentido, o risco do não-recebimento do conhecimento que seria transmitido ao interlocutor (Fricker, 2007), já que a narrativa do 
solicitante ou é vista como insuficiente ou como inadequada diante da complexidade da burocracia. É possível observar, ainda, o gradual desaparecimento dos solicitantes e a desapropriação das narrativas, incessantemente adequadas às expectativas burocráticas.

É preciso ressaltar aqui que a discussão sobre o formulário é realizada de maneira local e situada, considerando a perspectiva daqueles inseridos em uma instituição que representa a sociedade civil no CONARE e que percebem os rituais de orientação e preenchimento como práticas que impactam o processo de elegibilidade como um todo ${ }^{25}$. No que diz respeito a este impacto do ritual de preenchimento do formulário no processo de solicitação de refúgio, Marina, da Cáritas-Rio, trouxe à tona a importância desta prática de conversão da vida em documento:

Eu acho que o momento do formulário é um momento muito importante do processo, porque eu acho que é o primeiro momento em que a história vai ser escrita, a narrativa do refúgio vai estar registrada e é a base pela qual o CONARE se direciona para entrevista. Então eu encarava esse processo com muita responsabilidade para que fosse passado o máximo do que eu conhecia da minha experiência e do que foi passado para mim, do que é importante ser orientado, na forma de escrever esse processo, essa parte da história (Marina, Cáritas-Rio).

Na posição de voluntária recém-chegada ao trabalho na Cáritas-Rio, chamou minha atenção a necessidade de passar por alguns treinamentos com a equipe de advogados da instituição para compreender como orientar o solicitante no preenchimento e na leitura das vinte e seis páginas do formulário do CONARE. Dentre todas as páginas com espaço para preenchimento das informações pessoais do solicitante, aquelas convencionalmente caracterizadas como as mais importantes para a avaliação do pedido de refúgio são as que contêm perguntas sobre as razões que levaram o solicitante a deixar seu país de origem e a buscar proteção como refugiado no Brasil, o que ocorreria caso o solicitante retornasse ao seu país de origem e a existência ou não de algum temor de ameaça a sua integridade física ou

\footnotetext{
${ }^{25}$ Apesar da predominância da perspectiva dos atores da Cáritas-Rio, não é possível afirmar que o documento seja irrelevante para outras instituições. É preciso considerar que os rituais de preenchimento e orientação do formulário ocorrem normalmente em instituições da sociedade civil e que, portanto, é esperado que encontremos nesses locais mais pessoas interessadas em discutir o tema. Solicitantes e refugiados não trouxeram em suas falas o formulário como uma preocupação mesmo quando questionados a respeito. Por outro lado, levantaram a importância de outro documento que funciona como a identidade dos sujeitos no Brasil - o protocolo de refúgio. Mesmo sendo tema de interesse acentuado para todos os solicitantes e refugiados com os quais tive contato durante a pesquisa (e até anteriormente), uma discussão sobre este documento específico - e a precariedade que o envolve - está ausente da tese por necessidades de recorte analítico.
} 
mental ou a sua liberdade. Assim, minha própria orientação sobre o ritual de preenchimento do formulário, como voluntária da instituição, viu-se refletida na fala de outros atores da Cáritas-Rio sobre a prática. Conforme Ana me disse em entrevista, quando questionada sobre a orientação para o preenchimento:

Eu costumo começar com as mesmas informações da entrevista, explicar que Cáritas não é governo, que não adianta só preencher o formulário, que ele vai ter que entregar na Polícia Federal. Eu passo pela definição do refúgio, explico que é bem importante, pelo menos eu entendo como importante, a diferença entre migração por motivos econômicos e refúgio (Ana, Cáritas-Rio).

O formulário já preenchido pelo solicitante é, então, checado cuidadosamente por um dos advogados ou por um dos voluntários do setor de proteção legal e elegibilidade. De maneira geral, o trabalho de checar o preenchimento do formulário deve levar em conta se houve algum espaço deixado em branco pelo solicitante e que deve ainda ser preenchido e o desenvolvimento das respostas àquelas questões que salientei acima como as mais relevantes para o processo de elegibilidade. Nessas questões-chave, o solicitante é informado pelo funcionário/voluntário sobre a importância do detalhamento de sua narrativa e do desenvolvimento de respostas que podem ser mais extensas do que o próprio espaço oferecido pelo formulário - é comum informar ao solicitante que páginas e anexos podem ser acrescentados, sem que isso seja uma afronta aos parâmetros burocráticos do processo.

A estética do documento se torna, nesse contexto, relevante para as práticas da elegibilidade, uma vez que os formatos deveriam estar adequados ao testemunho do sujeito. Conforme afirmam Carel e Kidd (2014), analisando práticas de injustiça epistêmica em tratamentos de saúde, os formulários geralmente possuem espaço limitado para a descrição da experiência, impedindo a contextualização das narrativas, além da existência de práticas de preenchimento em espaços públicos com pouco tempo e privacidade para que o sujeito possa refletir sobre suas experiências $^{26}$. Sobre a estética do formulário de refúgio, especialmente no que diz

\footnotetext{
${ }^{26}$ Ainda que o formulário de solicitação de refúgio esteja disponível em meios eletrônicos, podendo ser preenchido pelo sujeito em qualquer local de sua preferência (e posteriormente entregue à Polícia Federal), minha experiência no campo e o relato de outros atores apontam para práticas de preenchimento na sede de instituições, como a Cáritas-Rio. Assim, o preenchimento geralmente ocorre em uma sala onde outros atendimentos estão sendo realizados em paralelo, com a circulação de funcionários, voluntários e outros solicitantes e refugiados. É normal, ainda, que o solicitante esteja acompanhado por outras pessoas, como amigos, conhecidos e familiares, e já tenha esperado pelo atendimento por algum tempo na sede da instituição.
} 
respeito ao desenvolvimento do motivo de saída do país de origem, Manuela afirmou em entrevista que:

É um espaço muito pequeno, aí a gente fala: ó, se você precisar de mais espaço a gente dá uma folha em branco, não escreve atrás, por que o CONARE quando for tirar cópia, não vai tirar cópia da parte de trás, então eles não vão ler a história toda (Manuela, Cáritas-Rio).

Ao ler as circunstâncias da solicitação, isto é, as razões pelas quais o solicitante de refúgio decidiu deixar seu país de origem ou residência habitual e buscar proteção como refugiado no Brasil, o funcionário/voluntário precisa avaliar se a explicação do solicitante está bem desenvolvida e detalhada. Da mesma forma que é preciso avaliar as respostas dadas à pergunta: o que aconteceria se você regressasse ao seu país de origem ou residência habitual? Na minha experiência como voluntária, foi comum ler respostas que diziam "nada", ainda que o solicitante tivesse detalhado sua narrativa sobre perseguição em espaço anterior no formulário. A prática do trabalho estimula o funcionário/voluntário a considerar barreiras culturais ou linguísticas e a dificuldade de compreensão do sentido subjacente às perguntas do formulário de solicitação. No que diz respeito a respostas que afirmam que "nada" aconteceria em caso de retorno ao país de origem, Manuela narrou um caso concreto em entrevista:

Teve uma pessoa que escreveu "nada", eu acho que foi um sírio, eu acho que era um sírio e ele escreveu "nada", e aí a gente foi perguntar para ele: como assim, não ia acontecer nada? A resposta dele foi tão interessante, ele falou assim: nada, porque no meu país não tem nada, não tem escola, não tem trabalho, não tem farmácia, não tem nada (Manuela, Cáritas-Rio, grifo meu).

Mais do que uma dificuldade de compreensão dos termos do formulário, o que respostas como esta relatada acima sugerem é uma diferença no modo de fazer sentido das experiências pessoais e de relatá-las ao outro. $\mathrm{O}$ estranhamento diante da narrativa do solicitante no processo é logo substituído pela busca por uma adaptação à linguagem burocrática do refúgio, de modo a facilitar uma leitura posterior por outros atores deste universo institucional. Assim, em casos como esse, é feita uma orientação para que o solicitante complete sua narrativa, desenvolvendo e detalhando seus temores - o que está em jogo é a constante necessidade de diferenciação entre o imigrante e o refugiado, de modo a produzir uma narrativa aceitável de perseguição. Uma história de refúgio não permite, então, "nada" como resposta, porque conforme nos diz Facundo (2017, p.237), é preciso "cavar no sujeito". 
A necessidade de adaptar as narrativas às "histórias de refúgio" pode gerar um bloqueio à circulação de idéias críticas (Fricker, 2007), fazendo com que o teor indignado de uma afirmação como "nada aconteceria se eu retornasse ao meu país" seja facilmente substituído por uma resposta padrão que retoma os medos de perseguição já narrados em outro espaço do formulário. Nos termos de uma injustiça essencialmente epistêmica, o conhecimento que seria transmitido ao interlocutor não é recebido - esteja este conhecimento relacionado ao modo de atravessar processos burocráticos ou ao modo de fazer sentido da experiência da violência como um espaço significativo de vazio ou ausência. Há, assim, um privilégio epistêmico dos atores responsáveis por avaliar os testemunhos, determinando quais os estilos de narrativa, as formas de evidência e os modos de compartilhar o conhecimento seriam mais adequados nesta troca testemunhal (Carel e Kidd, 2014), o que podemos ver refletido na busca pela adaptação dos testemunhos à linguagem do processo de refúgio. Ainda que as vozes dos solicitantes sejam aquelas mais importantes em termos das narrativas de perseguição, seus testemunhos são constantemente modificados para que possam encaixar nas expectativas envoltas no processo, conforme veremos melhor no próximo capítulo.

No ritual de preenchimento do formulário, e em meio a dificuldades e diferenças de compreensão e interpretação das perguntas, é conversado novamente com o solicitante de refúgio o que significa o estatuto, o que diz a lei brasileira 9.474/97 sobre o reconhecimento do refugiado, o que isso implica para a narrativa dele e a importância do detalhamento de sua história para o processo de análise de credibilidade. Há uma expectativa dos atores envolvidos nesse processo, e responsáveis por avaliar a solicitação de refúgio, que fica evidenciada em vários momentos: no preenchimento do formulário, na sua leitura e, finalmente, na sua revisão. O funcionário/voluntário da Cáritas-Rio, ao mesmo tempo em que possui suas próprias expectativas, procura também informar o solicitante sobre o que é esperado dele nesse ritual de preenchimento. A questão da busca por emprego, por exemplo, ou por uma "vida melhor" (expressão interpretada como sinal de que o solicitante pode ser um migrante econômico), é vista com cuidado por Maria, da Cáritas-Rio: 
Porque muitas vezes a pessoa chega para preencher o formulário e ela fala: Ah, é muito difícil eu conseguir emprego no meu país, que é uma situação muito séria, e às vezes ela não consegue emprego por motivo de opinião política. Então a gente explica que é muito importante, é muito sério, mas você vai ter que explicar porque isso aqui é relevante para o seu pedido de refúgio. Então tem uma orientação nesse sentido, de direcionar o relato para o que tem mais chance de uma resposta positiva do governo (Maria, Cáritas-Rio, grifo meu).

As expectativas sobre as histórias e seu encaixe à linguagem burocrática do refúgio atravessam o ritual de preenchimento do formulário, fazendo com que o funcionário da Cáritas-Rio se veja no papel de auxiliar os sujeitos no enquadramento das suas narrativas à lei do refúgio. Conforme minha própria experiência como voluntária me ensinou, é preciso estar atenta a qualquer expressão no formulário que indique a busca por uma vida melhor, uma vez que o seu uso é comumente visto como indicador de uma situação econômica sem fundamentos para a concessão do refúgio. Dessa maneira, está em questão não somente a dificuldade de interpretação das perguntas do formulário, mas também como o sujeito pode fazer sentido da sua própria experiência pessoal como um "caso de refúgio". Joana, da Cáritas-Rio, me contou sobre isso fazendo uso de um exemplo:

Por mais que a gente explique, algumas coisas são difíceis da pessoa entender porque às vezes são analfabetos funcionais, então as pessoas conseguiam ler, mas não entendiam as perguntas, então eu tinha que explicar cada uma das perguntas. E às vezes as pessoas não sabiam que o tipo de coisa que elas tinham sofrido era importante para colocar na narrativa. Por exemplo, uma vez uma menina não sabia explicar exatamente que ela estava ali por questão de gênero, porque no país dela eles fazem mutilação genital. Então ela tinha vindo para o Brasil porque ela não queria, ela tinha medo daquilo, não chegaram a fazer com ela porque ela saiu antes, mas ela não sabia explicar que ela poderia pedir refúgio com base nisso especificamente (Joana, Cáritas-Rio, grifo meu)

Poderíamos questionar a atuação das expectativas que produzem as "histórias de refúgio", com expressões-chave a serem evitadas nas narrativas e a constante busca por uma adaptação das experiências pessoais dos solicitantes à linguagem burocrática do refúgio (e sua necessidade de diferenciação entre o imigrante e o refugiado). O esforço de fazer sentido das próprias experiências sociais é atravessado pela necessidade de adaptação às expectativas dos atores envolvidos no processo. O ritual de preenchimento do formulário traz à tona, assim, as dificuldades dos sujeitos em fazer sentido de suas experiências e, ao mesmo tempo, encaixá-las no quadro do refúgio por elegibilidade. Teríamos, nesse sentido, o estabelecimento de práticas que demandam que o conhecimento do solicitante seja transmitido aos atores desse sistema, porém com a exigência de um 
enquadramento à linguagem legal-burocrática do refúgio. Conforme é possível ver no formulário, o solicitante não deve apenas narrar sua história, mas dizer com base em qual critério legal é possível enquadrar a sua solicitação. A importância do conhecimento do solicitante (sobre seu país de origem, por exemplo) é facilmente substituída pela expertise da orientação sobre o enquadramento da sua narrativa à lei do refúgio, relegando os solicitantes ao papel de "analfabetos funcionais" 27.

A credibilidade do sujeito pode ser afetada, então, pela existência de preconceitos relacionados à dimensão da competência, fazendo com que o outro seja visto como ignorante ou estúpido (Anderson, 2012). É preciso ter em mente que as avaliações de credibilidade não são realizadas apenas com base na dimensão da sinceridade, mas também da competência (Fricker, 2007). Neste caso específico que levanto aqui, a narrativa do solicitante é vista como incompetente, isto é, como inadequada ou insuficiente diante da complexidade da burocracia. A partir disso, e nos termos de uma injustiça epistêmica, "o conhecimento que seria transmitido ao interlocutor não é recebido" (Fricker, 2007, p.43). Para além de uma injustiça epistêmica relacionada exclusivamente à recusa em aceitar o testemunho do outro como verdadeiro ou crível, o que é possível ver aqui é, conforme nos diz Hookway (2010), uma injustiça epistêmica relacionada à recusa em levar a sério a habilidade do sujeito em prover conhecimento relevante em determinado contexto. Não seria, assim, uma questão de desacreditar o outro por uma suposta desconfiança em relação à verdade do seu testemunho, mas uma conduta discriminatória (ainda que inconsciente) por uma suposta incompetência do sujeito (Anderson, 2012). A narrativa do sujeito se torna, então, cada vez mais desapropriada, representando um obstáculo à sua participação ativa no processo de narrar a própria vida em documento burocrático.

Transmitir conhecimento ao outro através do testemunho e fazer sentido de suas próprias experiências sociais são, como nos diz Fricker (2007), práticas

\footnotetext{
${ }^{27}$ Ainda que a ênfase das análises esteja localizada sobre a possibilidade de produção de uma injustiça epistêmica, é preciso ter em mente a complexidade do processo e a tentativa, por parte de muitos atores da sociedade civil, de aumentar as chances de sucesso das solicitações. Considero, assim, que embora o efeito possa ser compreendido em termos de produção de injustiça epistêmica, as motivações por trás das práticas de encaixe das narrativas ao formato burocrático trazem à tona uma dimensão ambivalente. Nesse sentido, o esforço de orientação para o preenchimento do formulário também pode ser compreendido do ponto de vista de uma busca pelo deferimento da solicitação. Da perspectiva desta tese, porém, a ambivalência e a complexidade dos processos não diminuem a relevância de uma reflexão sobre como as práticas da elegibilidade podem evidenciar um processo que se construiu, estruturalmente e formalmente, de modo a facilitar a reprodução de injustiças epistêmicas através das etapas diárias de determinação do status de refugiado.
} 
epistêmicas diárias básicas. Em um dos primeiros rituais do processo brasileiro de elegibilidade já podemos ver emergir condições de possibilidade para a produção de uma injustiça essencialmente epistêmica. Ainda que não possamos falar aqui sobre o esvaziamento da credibilidade do outro, noção cara ao conceito de injustiça testemunhal, a restrição ao conhecimento produzido pelo solicitante já emerge neste início do processo de elegibilidade como um fator relevante a ser considerado - e que pode ter maiores implicações para a análise de credibilidade, a qual, entre outras coisas, contrasta as narrativas na entrevista oficial com as narrativas no formulário. Considero necessário, assim, refletir desde então sobre a existência de práticas que, ao mesmo tempo, demandam e restringem a circulação do conhecimento dos sujeitos que solicitam refúgio e são atravessadas por uma posição de privilégio epistêmico experimentada por alguns atores. Nas próximas seções, e conforme emerge uma economia da credibilidade nos procedimentos de determinação do status de refugiado, é possível analisar em maiores detalhes a possibilidade de manifestação de uma injustiça epistêmica, acessando as diferentes contribuições teóricas neste campo.

\section{4 \\ Os rituais de entrevista}

A avaliação da credibilidade do solicitante e a possível atribuição de déficits a sua narrativa são práticas analisadas detalhadamente nas seções posteriores, em que discutimos as interações entre os atores no processo de elegibilidade e seus debates sobre a existência ou não de uma base razoável para acreditar no que o outro diz. Antes disso, porém, o ritual das entrevistas emerge como uma prática significativa, uma vez que constitui a única troca testemunhal do processo na qual o solicitante se encontra diante de um oficial de elegibilidade do CONARE a fim de narrar oralmente a sua história. Assim, embora as discussões sobre credibilidade possam ser desenvolvidas a partir das etapas de produção dos pareceres sobre os casos, debates no GEP e votações na reunião do plenário do Comitê, a entrevista oficial constitui um espaço importante de troca testemunhal. É, então, neste espaço de encontro com o oficial de elegibilidade que o solicitante de refúgio se vê novamente diante da convocação de narrar seus medos de perseguição, sua história pregressa e, em detalhes, toda a sua vida. 
Tendo isso em mente, busco contribuir aqui para o debate em torno da entrevista como uma prática investigativa que, ao invés de estar relacionada à transmissão do conhecimento, encontra-se atravessada pelas imagens de "extrair informações”, "mapear" e "penetrar" os solicitantes de refúgio. Além disso, analiso a relação entre déficits e excessos de credibilidade, o privilégio epistêmico do oficial de elegibilidade e a busca por apagar sua presença nas práticas que determinam se o solicitante é ou não um sujeito crível. Embora este tema seja discutido em mais detalhes no capítulo seguinte, também levanto aqui a existência de uma concepção ambígua: o solicitante de refúgio precisaria confiar no oficial e em outros funcionários das instituições encarregadas do processo de elegibilidade, ao mesmo tempo em que necessitaria lidar com a desconfiança desses atores em relação a sua figura.

A concepção das entrevistas como práticas investigativas, e não voltadas à troca testemunhal para transmissão do conhecimento dos solicitantes de refúgio, abre espaço para o apagamento do papel do interlocutor em atribuir ou não credibilidade ao que é narrado e ao sujeito que conta sua história ${ }^{28}$. Dessa maneira, haveria um afastamento da noção da análise de credibilidade como uma prática que depende de uma comparação e contraste entre os atores envolvidos na troca testemunhal. Em outras palavras, diminui-se a relevância do caráter comparativo e da natureza de contraste de reconhecer alguém como crível ou não, deixando de lado o fato de que, conforme nos diz Medina (2011), qualquer déficit de credibilidade em relação ao testemunho de um sujeito é operado através da autoridade epistêmica ${ }^{29}$ implicitamente atribuída àquele que investiga ou questiona. Na relação estabelecida com o solicitante de refúgio na entrevista de elegibilidade, o oficial entrevistador detém implicitamente uma posição de autoridade que o torna encarregado de avaliar posturas, sentimentos, credibilidade interna e plausibilidade das narrativas. Nesse sentido, para que seja possível estabelecer a crítica ao modo como avaliações de credibilidade são conduzidas, com a possibilidade de produção de uma injustiça epistêmica, é preciso ter em mente as relações desiguais que atravessam o processo do refúgio por elegibilidade.

\footnotetext{
${ }^{28} \mathrm{~A}$ imagem da entrevista como prática investigativa também diminui a relevância da contribuição do solicitante enquanto sujeito de conhecimento, menosprezando a sua participação ativa na troca testemunhal e instaurando a posição passiva do investigado.

${ }^{29}$ Medina (2011) utiliza a expressão "autoridade epistêmica” como sinônima da posição de privilégio epistêmico desfrutada por aqueles sujeitos que recebem um excesso de credibilidade não-merecido.
} 
No processo de determinação da condição refugiada, a avaliação da credibilidade do solicitante não ocorre de maneira descolada de um regime de investigação sobre a verdade (Bohmer e Shuman, 2007). Conforme nos diz Toledo de Souza (2016, p.35), "trata-se de uma investigação sobre a verdade do solicitante, sobre sua credibilidade e sinceridade". Tal perspectiva encontra-se em sintonia com documentos oficiais que estabelecem o processo de constatação e avaliação dos fatos para a concessão do refúgio e que afirmam que o solicitante deverá: "dizer a verdade e apoiar integralmente o examinador no estabelecimento dos fatos [...] esforçar-se por apoiar as suas declarações com todos os elementos probatórios disponíveis e dar uma explicação satisfatória em relação a qualquer falta de elementos de prova [...]" (ACNUR, 2011, p.42, grifo meu). Apesar da constatação de que a dificuldade de provar os fatos narrados é um aspecto inerente à situação especial em que o solicitante de refúgio se encontra, considera-se que "a aceitação dessa possível falta de elementos de prova não pode significar que declarações não fundamentadas devam ser necessariamente aceitas como verdadeiras se as mesmas forem inconsistentes com a exposição geral dos fatos apresentados pelo solicitante" (ACNUR, 2011, p.42, grifo meu).

A perspectiva do processo de elegibilidade, e especialmente do ritual da entrevista, como uma investigação sobre a verdade é exposta também pelas falas de diferentes atores entrevistados durante a pesquisa. Para Carlos, coordenador do CONARE, a entrevista "é como uma investigação da vida da pessoa, vamos dizer que é uma conversa com formalidades". Ao descrever o espaço da troca testemunhal, o coordenador deixa claro aquilo que a pesquisadora Ángela Facundo também nos mostra com seu trabalho de campo: "não é questionado o fato de que exista uma verdade no sujeito" (Facundo, 2017, p.242).

As entrevistas elas são estruturadas, assim, é como uma investigação da vida da pessoa, vamos dizer que é uma conversa com formalidades, primeiro a gente se apresenta, explica qual é a nossa função, a gente explica o que é o refúgio, para o que ele serve, e fazemos algumas perguntas-chave, né: por que você saiu do seu país de origem, e o que aconteceria se você retornasse ao seu país de origem. Essas são duas perguntas-chave feitas em qualquer entrevista. Além disso, quando a pessoa conta a história a gente vai pedindo confirmação dos fatos. Uma das funcionalidades dessa técnica é de repetir a mesma pergunta várias vezes, mas em momentos distintos, é verificar se a pessoa cai em contradição ou não, se ela fica confusa ao responder, ou se ela tem certeza, fala com propriedade, enfim. Mas a entrevista ela é muito, é vamos dizer assim, tem um padrão, mas ela é muito variável porque depende da vida da pessoa também, mas existe uma moldura que a gente segue, vamos dizer assim. Tem uma moldura que a pintura é feita de acordo com o relato do solicitante, e a gente tem que saber o que fazer e como fazer, naquela condução 
né, dentro daqueles limites ali da entrevista. Então já tem, vamos dizer, tem um procedimento pré estabelecido, onde a gente se apresenta, pergunta se a pessoa está confortável, explica a nossa função, a gente fala que a gente é o MJ, é o responsável por fazer a entrevista né, tomar nota de tudo o que a pessoa falar, explica o que é o refúgio, e aí parte para a investigação do que era, como era a vida do solicitante no país de origem (Carlos, coordenador do CONARE, grifo meu).

A perspectiva investigativa norteia, assim, o imaginário daqueles responsáveis por estruturar e conduzir as entrevistas com o solicitante de refúgio, expressando o que Facundo (2017, p.242) chama de necessidade de "cavar, extrair e verificar, como ações que permitiriam chegar ao mais profundo da pessoa, em uma espécie de trabalho arqueológico que faria emergir o que está dentro dele". Segundo Tatiana, oficial de elegibilidade do CONARE responsável por realizar entrevistas, o importante é "saber quem é essa pessoa que estamos entrevistando". Para isso, seria preciso, nas palavras dela, "extrair informações, entender como ele se expressa, mapear a pessoa que estamos investigando". Novamente nos deparamos com uma prática norteada por uma visão investigativa não somente sobre a vida do solicitante, mas sobre seu próprio ser, que estaria sendo mapeado e extraído à procura de informações.

Teríamos, assim, menos uma prática voltada à escuta testemunhal, aberta à transmissão do conhecimento pelo outro, e mais uma postura de "penetração" da pessoa. O solicitante é visto não como um sujeito de conhecimento, mas como investigado. Esta perspectiva não foi expressa apenas pelos atores responsáveis por conduzir e estruturar as entrevistas de elegibilidade, mas também por membros que representam a sociedade civil no CONARE. Ao ser questionado sobre a existência de um perfil ideal de entrevistador, Júlio, da Cáritas-Rio, compara o oficial de elegibilidade à figura de um médico ou advogado:

[...] Esse perfil que eu estou falando, se você pensar, o médico, o advogado, boa parte da ação positiva do médico para chegar a um diagnóstico, um advogado entender como vai defender, é preciso que ele penetre um pouco na pessoa, que ele sinta, que ele seja partícipe, que ele se envolva, não o envolvimento do ponto de vista de tomar partido de situações e tal, mas no sentido de perceber exatamente qual é, o que está por dentro da pessoa, no caso do refugiado, o fundado temor (Júlio, CáritasRio, grifo meu).

O processo investigativo emerge, nesse contexto, como um elemento fundamental que irá ajudar a avaliar a credibilidade do solicitante de refúgio e de seu testemunho, ainda que esta possa ser uma prática não totalmente transparente. Para Fernando, da Cáritas-Rio, as perguntas realizadas pelo oficial do CONARE 
"são perguntas para avaliar a credibilidade, mas o problema é que elas não são feitas com essa transparência, são perguntas às vezes capciosas". Apesar de reconhecer como papel do oficial de elegibilidade realizar perguntas para avaliar a credibilidade dos sujeitos, Fernando afirma que “[...] não dá para dizer assim: ‘essa entrevista é para seu benefício de liberdade'. Não, não é. Tem um jogo todo aí [...] isso não é transparente isso que é o problema". Na perspectiva de Guelor, um refugiado da República Democrática do Congo (RDC) que já atravessou o processo, a existência deste "jogo" estaria clara: "você vai ver que a entrevistadora quer pegar o refugiado, pegar na mentira [...] volta na mesma pergunta de forma diferente, tenta desestabilizar o refugiado".

Ainda que possa não ser explicada para todos os solicitantes de refúgio como tal, a entrevista do CONARE funciona como instrumento para os julgamentos de credibilidade, sendo usada como meio de determinar se há base suficiente para se acreditar naquilo que o outro diz. Conforme me contou Tatiana, oficial de elegibilidade do CONARE:

Um dos pontos mais polêmicos é quando a gente vai analisar credibilidade interna e ponderar se ela foi aceita ou não, e o que não foi suficiente, e porque a pessoa não conseguiu ser crível e dar detalhes específicos e suficientes. É a parte que dá mais debate, mais dúvida e que mais depende do caso individual. O que reforça a importância da entrevista oficial. Pra analisar a credibilidade interna é preciso que a pessoa me conte, que ela me traga os elementos (Tatiana, oficial de elegibilidade do CONARE, grifo meu).

As perspectivas com as quais me deparei não trazem apenas a noção da existência de práticas responsáveis por atribuir ou não déficits de credibilidade ao outro, mas a ideia de que a própria pessoa entrevistada não teria conseguido ser crível, conforme vimos no trecho acima. De acordo com Simone, oficial de elegibilidade do Comitê, "muitas vezes o relato não conseguia ter credibilidade em si mesmo". O que emerge das falas de algumas entrevistadas parece sugerir um distanciamento da noção desta troca testemunhal como uma prática em que o papel do interlocutor, isto é, dos oficiais de elegibilidade, é atribuir ou não credibilidade ao que é narrado e ao sujeito que narra sua história. Ao invés de uma troca testemunhal em que teríamos a possibilidade de transmissão do conhecimento pelo outro, a depender de déficits de credibilidade atribuídos ao sujeito que narra, teríamos um espaço investigativo em que o solicitante é responsável por fazer-se crível. A extração de informações, o mapeamento e a penetração do sujeito emergem como um complexo de práticas investigativas voltadas para fazer emergir 
a verdade que estaria contida no solicitante, assim como sua própria credibilidade. Em casos deferidos, o solicitante de refúgio teria, então, provado ser crível.

Sem levar em consideração a existência de uma "economia da credibilidade", em que a credibilidade é distribuída de maneira desigual entre os atores (Fricker, 2007), não é possível compreender as condições de possibilidade para operação de uma injustiça epistêmica. A perspectiva de que o solicitante "não conseguiu ser crível" ou de que "o relato não conseguia ter credibilidade em si mesmo" parece desconsiderar que a troca testemunhal é intrinsecamente interativa e depende de julgamentos e alocações de déficits ou excessos de credibilidade. Embora Fricker considere a importância apenas de déficits de credibilidade, no quadro de uma injustiça epistêmica testemunhal, também é fundamental ter em mente que os excessos de credibilidade desempenham papel importante na produção de injustiças (Medina, 2011). Ser julgado crível não é algo que ocorre de maneira isolada, mas depende de uma comparação e de um contraste entre os atores envolvidos. Conforme nos diz Medina, a credibilidade apresenta um caráter comparativo e uma natureza de contraste, de modo que, ao atribuir um excesso de credibilidade a alguém, estaríamos concedendo ao sujeito um tratamento epistêmico privilegiado em comparação ao tratamento concedido a outro.

Há, assim, sempre uma relação entre déficits e excessos de credibilidade. Nesse sentido, ao contrário do que parecem supor as falas das oficiais de elegibilidade do Comitê, não há um déficit de credibilidade no vácuo. Não seria possível afirmar, então, que o relato não conseguiu ter credibilidade ou que o solicitante não conseguiu ser crível, uma vez que este tipo de afirmação desconsidera uma questão essencial dessas práticas: a credibilidade de nenhum sujeito pode ser apontada como deficitária de maneira independente da credibilidade dos outros que estão a sua volta. Conforme afirma Medina (2011), qualquer déficit de credibilidade em relação ao testemunho de alguém é operado através da autoridade epistêmica implicitamente atribuída ao sujeito que investiga ou questiona. No cenário da entrevista de elegibilidade, o oficial entrevistador detém implicitamente uma autoridade epistêmica que o tornaria capaz de julgar os sentimentos e a plausibilidade das narrativas dos solicitantes de refúgio. É possível considerar, ainda, que é esta mesma autoridade que permite que o oficial apague sua presença no processo de julgamento e esvaziamento da credibilidade do outro, passando apenas a afirmar que o testemunho (e o sujeito), independentemente da 
interação, não possui credibilidade em si mesmo. O excesso de credibilidade pode constituir, como diz Medina, uma misplaced trust $^{30}$ que contribui para a perpetuação de injustiças.

No processo investigativo conduzido pelos membros do CONARE também ganha relevância o papel que os atores atribuem à confiança. Tatiana, oficial de elegibilidade, após me contar sobre o "mapeamento" da pessoa que estão "investigando", afirma a tentativa de "criar uma relação de confiança desde o momento inicial da entrevista". A relação de confiança, porém, é entendida como uma forma de estabelecer a confiança do solicitante no entrevistador. Para a oficial, se "o primeiro contato do solicitante com o CONARE é geralmente na entrevista, então é preciso que eles se sintam pelo menos confortáveis".

A perspectiva sobre o papel da confiança na entrevista também é compartilhada por outros atores do processo, como Júlio, da Cáritas-Rio, que afirma que o entrevistador deve criar um ambiente de confiança a fim de que o outro possa narrar sua história. Segundo ele, a oficial de elegibilidade deve transmitir confiança e, assim, “a pessoa se sente segura para falar”. Já para Guelor, refugiado da RDC, a entrevista demonstra uma postura de desconfiança do oficial em relação ao solicitante, uma vez que "você já sente que a pessoa está duvidando do que você está falando e aí isso deixa a pessoa mais preocupada e ela começa a errar mais".

Eu: Você sente que a expressão corporal da pessoa é de duvidar do que você diz?

Guelor: De dúvida, sim, ou até chegar o momento que começam a dizer: para com isso, eu não estou acreditando. Me fala sua história verdadeira.

O papel da (des) confiança no processo será analisado em detalhes no próximo capítulo, mas cabe ressaltar brevemente aqui uma questão relevante na discussão sobre as práticas nas entrevistas. O que gostaria de levantar a respeito da confiança neste espaço de troca testemunhal não é apenas a disputa das narrativas sobre práticas que criam ou não um ambiente "confortável" para o solicitante de refúgio, mas a própria concepção de alguns atores do processo de que o que está em jogo é a necessidade de o solicitante confiar no oficial de elegibilidade. As referências ao problema da confiança como algo intrínseco à postura do solicitante em relação ao seu entrevistador parece desconsiderar o papel da confiança do oficial

\footnotetext{
${ }^{30}$ Por dificuldades de tradução de modo a manter o sentido original, optamos por utilizar no texto a expressão em inglês. Poderíamos, entretanto, traduzir livremente como confiança deslocada ou mallocalizada.
} 
no solicitante, novamente contribuindo para apagar a presença fundamental dos entrevistadores nos julgamentos de credibilidade - e, com isso, suas implicações em questões de injustiça epistêmica.

Ao discutir a possibilidade de um interlocutor virtuoso, Fricker (2007) nos lembra a necessidade de que este sujeito seja capaz de perceber o outro como confiável, o que passa necessariamente por uma emoção, um sentimento de confiança. Assim, uma condição básica para alcançar um quadro de justiça epistêmica é o estabelecimento de relações de confiança, e a ação de acordo com elas nas trocas testemunhais (Fricker, 2007; Medina, 2011). Dessa forma, a tentativa de apagar a presença do oficial de elegibilidade das práticas de atribuição de déficits de credibilidade também passa por um processo de deslocamento da confiança e que, novamente, não leva em consideração o caráter interativo das trocas testemunhais em uma "economia da credibilidade", nos termos de Fricker (2007).

Abandonar tentativas de apagamento da presença subjetiva do oficial de elegibilidade no processo de determinação do status de refugiado poderia levar os sujeitos a reconhecerem o caráter também subjetivo da própria análise de credibilidade. No esforço de resistir a isso, mantendo a legitimidade das decisões, os atores do CONARE reforçam a perspectiva do processo como objetivo e racional, retirando do cenário a participação ativa dos oficiais de elegibilidade nas práticas de atribuir/esvaziar credibilidade e desenvolver (ou não) um sentimento de confiança no solicitante através do engajamento emocional necessário. As práticas de apagamento da presença subjetiva do oficial de elegibilidade funcionam, assim, para produzir um conhecimento “desincorporado" (Haraway, 1998; Jensen, 2017), isto é, supostamente neutro, objetivo e que pode ser facilmente distanciado da subjetividade dos próprios solicitantes de refúgio e do conhecimento produzido por suas experiências pessoais. A suposta racionalidade objetiva que ganha espaço nas imagens sobre o processo de formação e atuação da burocracia da elegibilidade permite que o solicitante de refúgio seja relegado ao papel passivo de investigado, ao invés de participante ativo enquanto sujeito do conhecimento.

As práticas do refúgio por elegibilidade não estão restritas aos rituais de preenchimento do formulário e de condução das entrevistas oficias, mas atravessam os espaços coletivos de deliberação e análise das narrativas dos solicitantes. As concepções sobre casos "fortes" ou "fracos" e sobre o GEP como um espaço 
"técnico" de discussões serão analisadas no decorrer das próximas seções, a fim de que seja possível refletir sobre como os atores se posicionam diante das análises de credibilidade e dos impasses nas avaliações dos casos. Na próxima seção busco compreender alguns critérios que desempenham papel central nas avaliações sobre os solicitantes de refúgio e seus testemunhos, transitando pelas discussões sobre a importância atribuída ao detalhamento das narrativas e sua plausibilidade, bem como ao comportamento e à nacionalidade dos sujeitos. Emergem deste quadro de análise, contribuições relevantes acerca da existência de preconceitos e estereótipos sobre os solicitantes e refugiados, assim como a presença de um etnocentrismo que traz à tona não somente a dimensão testemunhal da injustiça epistêmica, mas também sua dimensão hermenêutica.

\section{5}

\section{Avaliando a credibilidade do solicitante}

Através da análise das práticas de avaliação de credibilidade é possível compreender a importância de um privilégio epistêmico que permite que determinados atores estabeleçam uma ausência de credibilidade interna como algo independente das trocas testemunhais, bem como suas considerações particulares sobre o que é plausível nos testemunhos dos solicitantes de refúgio. Torna-se fundamental, assim, analisar não somente a atribuição de déficits de credibilidade, mas também os excessos de credibilidade atribuídos a determinados sujeitos no processo de refúgio. Tais sujeitos acabam estabelecendo-se como capazes de julgar comportamentos, plausibilidade, coerência e consistência dos testemunhos, ao mesmo tempo em que buscam apagar seu papel ativo nessas avaliações. Não podemos desconsiderar, assim, uma característica fundamental da comunicação lingüística - as relações de dependência entre aquele que fala ou narra e a sua audiência (Dotson, 2011). Neste quadro, também emerge como crucial a análise de possíveis gaps na inteligibilidade da troca testemunhal, permitindo o esvaziamento da credibilidade dos solicitantes de refúgio. Para tanto, busco analisar a manifestação de um etnocentrismo nas avaliações de credibilidade, levando a uma incompreensão da experiência dos sujeitos e produzindo uma injustiça epistêmica em que suas duas dimensões (testemunhal e hermenêutica) ficam em evidência. 
Apesar de não constar na Convenção de 1951, relativa ao Estatuto dos Refugiados, nem mesmo na lei brasileira $\mathrm{n}^{\circ} 9.474$, a credibilidade é vista como um dos aspectos centrais mais desafiadores do processo de determinação da condição refugiada, uma vez que grande parte das rejeições de concessão do status é baseada na justificativa de que a autoridade competente não acredita naquilo que o solicitante de refúgio diz (Hungarian Helsinki Committee, 2013). A credibilidade é estabelecida quando o solicitante apresenta uma reivindicação consistente e plausível, que não contradiz os fatos gerais conhecidos e, com isso, é capaz de ser acreditada (idem). No processo de determinar a credibilidade de uma solicitação de refúgio, então, seria preciso avaliar sua consistência interna, ou seja, se a narrativa do solicitante é bem detalhada e não apresenta contradições; sua consistência externa, isto é, se as afirmações do solicitante estão em conformidade com outras evidências objetivas e fontes de informação, especialmente no que tange ao país de origem; e a plausibilidade ou a possibilidade de que aquilo que está sendo narrado possa ter acontecido ou possa vir a acontecer de fato (ACNUR, 2013; Hungarian Helsinki Committee, 2013).

No universo brasileiro da elegibilidade, é comum ouvir os atores se referirem à credibilidade através das expressões "caso forte" e "caso fraco". $\mathrm{Na}$ minha experiência no campo, a determinação da suposta força ou fraqueza de uma solicitação de refúgio parecia envolver um julgamento advindo da experiência prática do ator responsável pela análise de credibilidade, sendo difícil racionalizar os critérios que permitiriam fazer tal avaliação. Durante as entrevistas, a questão emergiu novamente das falas dos diversos atores sobre se um caso "vale à pena" ser defendido pela instituição nos espaços coletivos de discussão e decisão ${ }^{31}$. Muitas dessas falas trouxeram à tona a importância do feeling na avaliação das solicitações de refúgio, se afastando da tarefa de racionalizar as decisões - o que veremos em detalhes no próximo capítulo. Outros atores adicionaram elementos importantes sobre avaliações da credibilidade interna nas práticas classificatórias

\footnotetext{
${ }^{31}$ Assim como procurei destacar no ritual de preenchimento do formulário, é importante ter em mente os esforços dos atores de instituições da sociedade civil na busca pelo deferimento do maior número possível de solicitações de refúgio. Nesse sentido, pude apreender, tanto na minha experiência como voluntária quanto nas entrevistas da pesquisa, a existência de uma estratégia bem difundida entre estes atores de buscar defender os casos que teriam mais chances de deferimento pelo CONARE. A avaliação de tais chances é normalmente entendida como um conjunto de fatores que vão desde o histórico dos deferimentos/indeferimentos de casos similares até a complexa análise de credibilidade que também acaba sendo realizada nestes contextos.
} 
sobre a força ou fraqueza dos casos. Na Cáritas-Rio, por exemplo, onde há a condução de entrevistas com os solicitantes, os funcionários e voluntários são orientados a identificar o que chamam de "pontas soltas" nas narrativas. Conforme me contou Cecília, existe a prática de "separar os pontos fracos das entrevistas, que podiam ser problemáticos". O esforço do detalhamento das narrativas, a fim de evitar supostos pontos cegos, é levado ao extremo nesse processo, conforme me contou Beatriz, da Cáritas-Rio:

Então nós trabalhamos detalhes - e detalhes dos mais básicos. Por exemplo, se houve um ataque, que roupas as pessoas estavam usando; que época mais ou menos do ano foi, se é uma época mais chuvosa entre maio, junho, enfim, trabalhar a questão de temporalidade. Por exemplo, questão de horas e que local aconteceu também é difícil de identificar. Então para tornar uma realidade mais próxima da gente, a gente pelo menos tenta falar assim: aconteceu durante a parte da manhã, da tarde, final da tarde, ainda estava sol, justamente porque elas tentam apagar esse trauma, a gente tenta pelo menos pensar, ainda estava sol, estava noite, porque o oficial, o que normalmente faz a entrevista do Rio, quanto mais detalhes eles fornecem, ele acha que a narrativa fica mais crível né, então aumenta o nível de credibilidade interna, isso aumenta as chances dessas pessoas serem deferidas (Beatriz, Cáritas-Rio, grifo meu).

O esforço em torno do detalhamento das narrativas, orientado em função de critérios pré-estabelecidos pelos sujeitos responsáveis por avaliar os testemunhos dos solicitantes de refúgio, parece não levar em consideração os desafios de qualquer projeto auto-narrativo. Nos termos propostos por Butler (2017), as narrativas que os sujeitos constroem de si mesmos são sempre parciais, uma vez que "a vida pode ser entendida exatamente como aquilo que excede qualquer relato que dela possamos dar" (idem, p.61). A busca incessante por uma verdade definitiva e completamente coerente sobre a história do solicitante de refúgio, os motivos de sua fuga e seus temores de perseguição, ignora a existência do que Butler denomina de "verdade da pessoa", isto é, "uma verdade que, até certo ponto e por razões que já sugerimos, poderia se tornar mais clara nos momentos de interrupção, obstrução e indefinição - nas articulações enigmáticas que não se podem traduzir facilmente em forma narrativa" (idem, p.86). Haveria, assim, uma busca não razoável em torno de um projeto auto-narrativo que exige do sujeito um testemunho detalhado das "razões pelas quais sua vida tomou o caminho que tomou" (idem) a fim de determinar a completa coerência do solicitante em seu testemunho.

Em termos menos filosóficos e mais voltados à "economia da credibilidade" (Fricker, 2007), exige-se do solicitante de refúgio lembranças detalhadas de locais, 
datas, pessoas, cronologias de eventos e fatos cotidianos que dificilmente seriam memorizados por qualquer sujeito em situação não-traumática e na ausência de obstáculos lingüísticos e culturais (Cameron, 2010). Cabe salientar aqui como o próprio projeto construído em torno de avaliações de credibilidade se depara com os obstáculos à existência de uma narrativa totalmente coerente do sujeito sobre si mesmo e os eventos a sua volta. Sendo a "economia da credibilidade" no instituto do refúgio baseada em uma busca incessante por uma narrativa coerente, consistente e plausível, seu objetivo e instrumentos parecem ignorar, como afirma Butler, a impossibilidade de sermos seres autobiográficos totalmente coerentes. Permanecem, então, as práticas de construção da força ou fraqueza dos casos de solicitação de refúgio ${ }^{32}$.

$\mathrm{Na}$ tentativa de me explicar melhor o que os atores definem como pontos fortes ou fracos nas narrativas, Fernando, da Cáritas-Rio, me contou:

Fernando: Se uma pessoa faz uma narrativa e ela não sabe explicar o dia que ela saiu do país, uma questão cronológica simples, mas ela não sabe explicar, isso é um ponto fraco que vai minar a credibilidade dela. E, às vezes, não é porque a pessoa mentiu. É porque ela se perdeu, esqueceu, não deu atenção a isso ou é confusa mesmo. Porque é um detalhe que passa despercebido. As pessoas não prestam atenção nisso. E ponto forte é valorizar né, às vezes tem coisas que a pessoa fala de uma maneira que é assim...

Eu: Suaviza algo?

Fernando: Ah, meu pai era um alto funcionário, isso passa assim. Mas opa espera aí: o que você falou? E essa outra coisa, assim, que eles passam na narrativa, que permita o entrevistador ter uma imaginação, ou seja, ter imagens do que aconteceu. Para não ficar uma coisa burocrática, assim, aconteceu isso, sim, não. Dar imagem significa dizer para ele: olha era manhã, eu estava em tal lugar, era uma rua assim. Ajudar essa pessoa, porque o convencimento não é racional, convencimento é assim, possibilitar imagens que a pessoa consiga imaginar ah isso é razoável...

Sem entrar em considerações sobre práticas de convencimento e seu caráter não-racional, tema que abordaremos no próximo capítulo, a idéia do que seria "razoável" no testemunho de um solicitante de refúgio traz à tona a questão da

\footnotetext{
${ }^{32}$ Cabe ressaltar que, assim como no ritual de preenchimento dos formulários, há uma ambivalência nas práticas de entrevista realizadas em instituições da sociedade civil. Ainda que possamos identificar uma dimensão de produção de injustiça epistêmica, conforme procuramos detalhar na análise, também é possível apontar a busca por aumentar as chances de obtenção do status de refugiado. Assim, tais entrevistas complementares (não-obrigatórias) se desenvolvem cada vez mais sob a perspectiva de uma preparação para a entrevista oficial do CONARE do que como uma entrevista para determinar a credibilidade do solicitante. Dessa forma, funcionários e voluntários dessas instituições trabalham em conjunto para apontar possíveis problemas nas narrativas e estimular o detalhamento tendo em vista as dinâmicas da entrevista oficial e as chances de deferimento.
} 
plausibilidade nas avaliações de credibilidade, permitindo questionamentos sobre como é possível julgar plausível (ou não) aquilo que é narrado pelo solicitante de refúgio. Carlos, coordenador do Comitê, me contou sobre isso que:

[...] a primeira coisa que a gente faz é averiguar se aquele relato tem credibilidade ou não. Às vezes a história ela é assim: eu vim para cá porque eu fugi de uma magia negra do meu tio. E aí você fala: epa! Espera aí, não tem credibilidade né?! A pessoa pode até acreditar naquilo, mas não teria realidade esse acontecimento (Carlos, Coordenador do CONARE).

Curiosamente, este caso particular ao qual o coordenador do CONARE se referiu, foi levantado por Vítor, da DPU de Brasília, que sustenta uma posição diferente sobre a plausibilidade da solicitação de refúgio em casos nos quais os sujeitos alegam a bruxaria ou feitiçaria como razão do temor de perseguição:

[...] Casos interessantes, por exemplo, de feitiçaria em país da África, bruxaria, pessoas que alegam perseguição por estarem sendo vítimas de feitiçaria ou de bruxaria. É interessante esse caso porque, em princípio, esses casos em que houve indeferimento estavam num plano extremamente idealizado [...] Uma criança religiosa ela entendia que estava sendo enfeitiçada ou era vítima de bruxaria, enfim. E o que eu questiono um pouco, assim, que o CONARE dizia, mas se está nesse plano idealizado, a gente não pode fazer uma perseguição concreta. Então nesse caso houve indeferimento, mas leva um pouco ao questionamento se a gente também não está tendo uma visão muito etnocêntrica né. A gente sabe que isso estando na crença de algumas pessoas, essa perseguição por bruxaria ou feitiçaria, em princípio, ela pode também se manifestar de alguma forma no plano concreto né. Então leva um pouco a discussão até que ponto na definição dos elementos de refúgio também não tem uma visão extremamente etnocêntrica e sem considerar as peculiaridades culturais dos países de onde as pessoas provêm (Vítor, DPU de Brasília).

A menção à existência de um etnocentrismo na postura da coordenação do CONARE traz à tona a preocupação com seu impacto na avaliação dos marcadores de credibilidade, bem como a possibilidade de produção de uma injustiça epistêmica. Conforme nos diz Anderson (2012), o etnocentrismo pode fazer com que alguns grupos em posição vantajosa diminuam a credibilidade de membros de outros grupos em posição de desvantagem. Este cenário poderia reafirmar, inclusive, uma forma de injustiça hermenêutica, uma vez que, impactando negativamente a posição epistêmica de alguns sujeitos, reforçaria as desvantagens que os mesmos já sofrem por pertencerem a um grupo marginalizado (Anderson, 2012). Assim, a existência de um etnocentrismo pode fazer com que membros de um grupo em posição vantajosa na sociedade fiquem isolados das perspectivas dos sujeitos de outros grupos. A partir dos termos de análise propostos por Anderson, para aqueles que desfrutam da posição inquisitiva experimentada pela coordenação do CONARE, seria difícil fazer sentido daquilo que o solicitante relata como um 
medo fundado a respeito de feitiçarias, uma vez que estariam ausentes os recursos interpretativos adequados para compreender determinadas experiências.

A injustiça epistêmica que pode derivar desse cenário estaria relacionada, então, à dimensão hermenêutica - é difícil dar credibilidade àqueles que não achamos inteligíveis (Anderson, 2012). Teríamos não necessariamente um preconceito restrito à troca testemunhal, mas uma incompreensão mais ampla da experiência do outro. A perspectiva desenvolvida por Fricker (2007) nos ajuda a compreender como o entendimento sobre as experiências sociais (próprias e do outro) é uma esfera de atividade epistêmica em que uma forma hermenêutica de injustiça pode se manifestar, fazendo com que determinados grupos sociais não consigam divergir de compreensões distorcidas das suas experiências sociais. Em relação ao caso que levantei nos parágrafos anteriores, poderíamos observar a existência de uma lacuna nos recursos hermenêuticos coletivos que impediu a compreensão da experiência do sujeito acerca de seu medo em termos de uma perseguição no plano concreto. A posição desigual desfrutada por solicitantes e refugiados nas relações de poder impede que estes sujeitos participem ativamente da produção de significados coletivos a partir de suas experiências sociais, como podemos observar no decorrer de todo o capítulo, fazendo com que o impacto material de seus temores de perseguição seja diminuído pelos outros atores do universo institucional do refúgio. Nesse sentido, e como nos diz Fricker (2007), o solicitante não conseguiu tornar inteligível algo específico de sua experiência que seria importante poder comunicar e tornar compreensível.

Apesar das questões relacionadas à plausibilidade das narrativas serem fundamentais - e alvo de disputas e embates entre os atores - também podemos ver como a dimensão interna da credibilidade dos testemunhos e seus sujeitos é igualmente relevante. Vítor me conta a lógica das escolhas dos casos que a instituição vê como "valendo à pena" defender nos espaços coletivos, como o GEP, e a importância central atribuída à credibilidade interna:

A gente examina todos né e vê quais são os mais fortes. Por exemplo, tem alguns critérios que a gente vem utilizando, alguns casos que tem problema de credibilidade interna, a gente tenta não brigar tanto entendeu? Aquela discussão se o relato do cara é coerente ou não. Porque se o ponto de partida já está com problema, aí a chance de ganhar isso no CONARE é muito pequena, quando eles identificam contradição interna no discurso da pessoa e aí chegam à conclusão que não há uma credibilidade interna fica mais difícil defender (Vítor, DPU de Brasília). 
A suposta falta de coerência nos testemunhos e a presença de contradições internas ao discurso surgem da fala do funcionário da DPU como questões que minam qualquer esforço de defesa da solicitação de refúgio. Aqui, novamente, vemos emergir o apagamento da presença epistêmica privilegiada dos sujeitos responsáveis por avaliar a credibilidade do solicitante, fazendo emergir a visão de que a credibilidade interna seria algo dado, independente das trocas testemunhais em que a narrativa dos solicitantes de refúgio é demandada e produzida. É desconsiderada, portanto, uma característica fundamental da comunicação lingüística - as relações de dependência entre aquele que fala ou narra e a sua audiência (Dotson, 2011). Sem levar em consideração as trocas testemunhais através das quais o solicitante narra sua história, em formulário e em entrevistas, não é possível compreender como a credibilidade do sujeito foi diminuída pelo seu interlocutor - surgindo, em última instância, como algo já ausente, como podemos observar através da fala de que "não há uma credibilidade interna". Não se discute, assim, como a possível existência de gaps na inteligibilidade da troca testemunhal poderia permitir que o oficial de elegibilidade concedesse um nível esvaziado de credibilidade ao solicitante de refúgio.

Um fator polêmico também considerado relevante na análise da credibilidade interna é o comportamento do solicitante de refúgio ou a sua linguagem não-verbal, isto é, como este sujeito se comporta ao narrar sua história. O uso desse indicador de credibilidade é comumente baseado na premissa de que certos padrões de comportamento são indicativos de que a narrativa do solicitante é crível, o que inclui como o indivíduo se porta diante de uma entrevista de elegibilidade, seu nível de nervosismo, a coloração de sua pele durante questões difíceis, o ritmo de sua fala e a demonstração de emoções ao narrar certos eventos traumáticos (Hungarian Helsinki Committee, 2013). Tais fatores são comumente vistos como potenciais indicativos da autenticidade de uma solicitação de refúgio. Entretanto, mesmo o arcabouço normativo que dispõe sua importância também salienta suas falhas e limites, tendo em vista a dependência cultural desse indicador de credibilidade. Afirma-se, com isso, a possibilidade intrínseca de falhas que acompanham não só o indicador do comportamento, mas também aquele da plausibilidade, uma vez que os dois são vistos como determinados subjetiva e culturalmente (ACNUR, 2013; Hungarian Helsinki Committee, 2013). 
No caso brasileiro, Simone, oficial de elegibilidade do Comitê, me contou em entrevista que os fatores comportamentais não devem ser levados em consideração durante as entrevistas, uma vez que "a avaliação de credibilidade não dá espaço para opinião pessoal. Por isso, essa questão da forma de falar, se a pessoa está nervosa ou não, eu tentava não levar em consideração”. A mesma oficial, porém, relatou que a prática de avaliar o comportamento do solicitante de refúgio ao narrar sua história já teria sido comum em entrevistas conduzidas por outros oficiais de elegibilidade. Segundo ela, haveria agora um reconhecimento maior de que "a postura, o comportamento, chorar, não são uma questão. Temos agora treinamentos para não entender isso como determinante". Segundo a entrevistada, não haveria apenas treinamentos de orientação sobre o tema, mas uma política de desligamento de oficiais do CONARE que façam pareceres de elegibilidade com base no comportamento do solicitante de refúgio.

Apesar do relato da oficial de elegibilidade do Comitê, o coordenador do órgão se refere à entrevista como prática que emprega a técnica de "repetir a mesma pergunta várias vezes, mas em momentos distintos" a fim de que seja possível "verificar se a pessoa cai em contradição ou não, se ela fica confusa ao responder, ou se ela tem certeza, fala com propriedade" (grifo meu). Destaco, assim, na fala do coordenador do CONARE em relato sobre a condução das entrevistas, o uso de expressões que dizem respeito diretamente a como o solicitante se comporta ao ser entrevistado. Nesse sentido, verificar a credibilidade interna relacionada à existência ou não de contradições estaria ligado ao comportamento do solicitante de refúgio - se ele demonstra, com seu gestual, postural, entonação da voz, um comportamento "confuso" sobre o que lhe é indagado ou se ele "fala com propriedade" sobre o assunto. Uma análise sobre a confusão ou certeza expressa pelo solicitante passa, necessariamente, por uma avaliação do seu comportamento - o que impacta a determinação da suposta "força ou fraqueza de um caso", na linguagem expressa pelos atores do processo.

Uma questão importante que emerge nesse quadro geral da credibilidade diz respeito às informações sobre o país de origem ou a nacionalidade do solicitante de refúgio, permitindo a ligação dos fatores comportamentais com evidências externas. O processo de elegibilidade se baseia em uma busca pela verdade que estaria não somente no corpo do sujeito refugiado, com as fronteiras da nacionalidade que marcam os corpos (Amoore, 2006), mas também no território geográfico do qual 
ele fugiu (Facundo, 2017). Em termos das marcas corporais da nacionalidade, alguns traços físicos e comportamentais são comumente atribuídos a certos grupos nacionais - ou a agrupamentos mais amplos e regionais. Manuela, da Cáritas-Rio, por exemplo, me contou em entrevista que "atender um latino é muito diferente de atender um africano", embora quando questionada sobre o motivo da diferença tenha dito apenas que "não sei, o jeito é diferente". Em entrevista, Jorge, da Polícia Federal, me contou sobre como teria aprendido, na prática diária do trabalho com solicitantes e refugiados, a relacionar alguns traços comportamentais a certas nacionalidades:

Eu: Como é essa relação com o refugiado ou com o solicitante? É fácil a comunicação, o diálogo?

Jorge: Hoje em dia é mais fácil, a gente já aprendeu umas coisinhas e tal, até alguns costumes por causa do contato do dia-a-dia. O árabe ele é mais tranqüilo. Sírio é sensível. Os africanos também são legais e tal. O Cubano é meio desconfiado, mas é bom. Todos eles são bons. Chinês é complicado.

Eu: Por quê?

Jorge: Chinês não confia nem na mãe. Você está ajudando o cara e o cara está desconfiando de você. Mas é da cultura deles, um país milenar já sofreu tanto revés que eu até entendo.

Este quadro de articulação entre fatores comportamentais e nacionalidade produz não somente a expectativa de como um solicitante de refúgio de determinado país de origem deve se comportar, mas também de como ele deve apresentar algumas características natas que o fazem, por exemplo, dramatizar ao extremo sua própria história, gerando um sentimento de descrença por parte do oficial de elegibilidade (Jubany, 2011, 2017). No caso brasileiro, é possível ver a alteração das práticas da entrevista e da preparação para este encontro com o solicitante. Conforme me contou Simone, oficial de elegibilidade do CONARE, "a ordem cronológica [do relato do solicitante] é um problema cultural". Assim, a oficial se preparava anteriormente: “da próxima vez que for fazer [entrevista] com essa nacionalidade eu preciso tentar planejar melhor, exigir mais perguntas ou ter mais tempo de entrevista". Para ela, deveria haver um oficial de elegibilidade para cada nacionalidade, ou grupos de nacionalidades, criando uma expertise nas avaliações de credibilidade dos solicitantes de refúgio de acordo com suas origens.

As articulações entre características supostamente inatas ou fatores comportamentais e nacionalidade dos sujeitos traz à tona o papel de estereótipos e 
preconceitos nas avaliações de credibilidade. Embora não possamos afirmar, a partir das falas trazidas anteriormente, que houve a atribuição de déficits de credibilidade com base em estereótipos e preconceitos, há uma indicação aqui sobre a relevância dessas imagens sociais no processo de elegibilidade. A alteração das práticas da entrevista com base na nacionalidade dos sujeitos, por exemplo, pode demonstrar a existência de um "compromisso cognitivo com alguma generalização empírica sobre determinado grupo social" (Fricker, 2007, p.31) - nesse caso, a idéia de que uma nacionalidade específica tem problemas para relatar sua história de maneira cronológica. O estereótipo conectado com um tipo particular de preconceito identitário acaba gerando, então, generalizações empíricas não confiáveis sobre o grupo social em questão. Depende, assim, de uma análise contextual em relação às práticas de entrevista a verificação da existência de preconceitos e estereótipos, bem como da extensão do seu impacto na avaliação da credibilidade dos sujeitos ${ }^{33}$.

Através de um processo contínuo de associação da nacionalidade do sujeito a traços comportamentais, os diferentes atores envolvidos no processo de elegibilidade não somente produzem expectativas sobre os solicitantes e, com isso, alterações nas suas práticas, mas também determinam quais tipos de pessoas de certos países irão solicitar refúgio e quais tipos de histórias elas trarão consigo. Sobre o teor das "histórias de refúgio", Cecília, da Cáritas-Rio, relatou em entrevista como as narrativas de certas nacionalidades são comparadas pelo grau de violência envolvido:

Eu: Mas você acha que era difícil separar o imigrante econômico do refugiado?

Cecília: Olha, eu acho que não era tão difícil, porque as histórias eram bem cabulosas [risos] ... Eu lembro que os pareceres que comumente eram julgados como nãorefúgio, eu acho que eram de Angola [...] eles eram julgados como se não fossem refugiados, porque a maioria não tinha nenhum grande trauma assim, ou nenhum grande... Em relação às histórias que a gente lia do Congo, os de Angola eram tranqüilos, sabe?!

Eu: Como assim tranqüilos em relação ao Congo?

Cecília: De serem violências menores, né?!

Eu: E o que é uma violência menor?

\footnotetext{
${ }^{33}$ Tendo em vista a aura de sigilo e confidencialidade que marca os processos de refúgio no Brasil, não foi possível acompanhar os espaços de debate e julgamento sobre as solicitações, nem mesmo os pareceres com as justificativas para deferimento ou indeferimento dos casos.
} 
Cecília: Não tinha estupro, não tinha morte, não tinha visto metade da família, sei lá... tinham muitos casos de, eu lembro de ler do Congo, de morte por facão ou por situações assim horrorosas. Então, em Angola era mais uma perseguição política, de que era de um partido, aí tinha entrado outro partido e aí ele tinha ficado inseguro, sofreu algumas ameaças, sabia que um fulano tinha ficado preso, e aí achava que ele podia ser o próximo, então, não que era uma violência menor, é o medo também...

Eu: Então você acha que essa concepção de ter sido uma violência menor em relação a outros casos piores influenciava na hora de conceber a pessoa como refugiado?

Cecília: Com certeza, quando a história era cabulosa, para todo mundo, era muito mais fácil uma história com grau de violência muito grande ter um parecer favorável do que uma que não tinha.

Em relação ao território geográfico, e conforme nos diz criticamente Jubany (2017), é visto como uma espécie de bom senso entre os oficiais a perspectiva de que certos países são seguros e, portanto, não podem produzir solicitantes de refúgio merecedores de proteção. A fim de substanciar esta perspectiva, os oficiais de elegibilidade estudados pela autora (em práticas de determinação do status de refugiado no Reino Unido) são munidos de listas de países seguros - o que significa a própria ausência da necessidade de explorar uma determinada solicitação de refúgio, decidida apenas com base nessa análise prévia do país de origem (Jubany, 2017). Embora o Brasil ainda não produza uma lista de países seguros, a questão da nacionalidade emerge como fator central para os processos de elegibilidade. Segundo Carlos, coordenador do CONARE:

A nacionalidade é questão crucial para o processo da determinação da condição de refugiado. É com base na nacionalidade que a gente vai pesquisar a realidade do país de origem, porque possivelmente é lá que os fatos originários da perseguição ocorreram, então é questão crucial. Hoje todos os processos são analisados individualmente, então mesmo de países em que a gente tende a crer que é um ambiente seguro, e me permita listar alguns, Estados Unidos, Canadá, Austrália, Nova Zelândia, e Europa, a parte Oeste da Europa, a gente analisa né, individualmente [...] O CONARE não tem lista de países considerados seguros, mas isso é uma hipótese que sempre é aventada, de começar a criar essa prática né, ainda não temos muito certo como fazer isso, ou se está maduro ainda para criar, mas é uma possibilidade que sempre é aventada. Eu penso que isso ajudaria muito a resolver backlog né, o grande número de passivos do refúgio, ou você tem uma decisão em bloco ou você não consegue resolver com os recursos disponíveis hoje (Carlos, Coordenador do CONARE).

Apesar do coordenador do Comitê afirmar que a nacionalidade é relevante para a pesquisa sobre credibilidade externa, isto é, sobre os fatos no contexto do país de origem do solicitante de refúgio, a questão também emergiu das entrevistas de outros atores como uma forma de determinar, por si só, a força ou fraqueza de um caso. Ao questionar Camila, da Cáritas-Rio, sobre sua concepção acerca de um 
"caso fraco", ela me contou que "eu acho que, nesse caso, foi avaliado que era um caso fraco porque a pessoa tinha nacionalidade haitiana". Para ela, existe uma prática do CONARE em avaliar a força ou fraqueza de casos a partir da nacionalidade dos solicitantes de refúgio, o que também seria reproduzido pelas instituições da sociedade civil. Segundo Camila, "a Cáritas acaba reproduzindo de alguma maneira esse tipo de diretriz do CONARE, e do ACNUR, é importante destacar que isso também é diretriz do ACNUR". Na perspectiva da funcionária, então, não só a nacionalidade desempenha papel de destaque na avaliação dos casos, mas "é normalmente algo que segue uma diretriz que vem da própria estrutura das instituições ligadas ao refúgio no Brasil”"

Ainda que o coordenador do CONARE tenha afirmado que, a despeito da nacionalidade, as solicitações são avaliadas individualmente, a funcionária da Cáritas-Rio me contou que "existiu um período também que o CONARE parou de deferir casos de pessoas angolanas sob o argumento de que não havia mais conflito". Muitos entrevistados, quando questionados sobre a existência de uma lista informal de países considerados seguros, afirmaram que existe uma concepção extra-oficial a respeito das nacionalidades que podem constituir um "caso de refúgio". Em entrevista com Joana, da Cáritas-Rio, um "caso forte” é definido, dentre outros fatores, pela nacionalidade do solicitante:

É, caso forte é tipo assim, se é de um país que, enfim, tem uma série de coisas que são levadas em consideração, então se for um país que tenha uma questão política muito conturbada e a história da pessoa faz menção a isso, aí você entende que aquilo é possível. Ou então, sei lá, é um caso de perseguição de gênero no Congo, que é a capital mundial do estupro. Então, assim, são informações que, juntas, existe como se fosse um pré-entendimento de que aquilo realmente é verdade, realmente acontece (Joana, Cáritas-Rio).

As constantes menções à força ou fraqueza de casos, à perspectiva da credibilidade interna como algo dado ou determinado pelo próprio solicitante, à suposta interligação entre características ou comportamentos e a nacionalidade dos sujeitos, bem como à plausibilidade das "histórias de refúgio", ajudam a compor as práticas da elegibilidade. Através da análise de tais práticas, é possível compreender como uma "economia da credibilidade" (Fricker, 2007) diz respeito essencialmente "aos modos pelos quais a credibilidade é distribuída de forma desigual entre diferentes sujeitos" (McKinnon, 2016, p.438). Apenas assumindo uma posição de privilégio epistêmico seria possível determinar uma ausência da credibilidade 
interna como algo independente das trocas testemunhais ou aquilo que é plausível nos testemunhos e estilos narrativos dos sujeitos. Não basta, nesse sentido, analisar a atribuição de déficits de credibilidade em relação aos solicitantes de refúgio, mas é preciso refletir sobre excessos de credibilidade atribuídos aos seus interlocutores, considerados capazes de julgar comportamentos, plausibilidade, coerência e consistência dos testemunhos e seus sujeitos, ao mesmo tempo em que buscam apagar seu papel ativo nessas avaliações. Conforme nos diz Hiebert (2015), enquanto aqueles que têm seu papel como sujeito de conhecimento diminuído devido a déficits de credibilidade sofrem de uma injustiça epistêmica, aqueles que estão em uma posição de poder ou status experimentam um privilégio epistêmico, com a aceitação de seu conhecimento apenas em função da posição de autoridade da qual desfrutam.

A partir deste quadro de práticas da elegibilidade, é possível perceber como "o excesso de autoridade epistêmica de alguns constitui uma injustiça diretamente relacionada ao déficit de credibilidade de outros" (Medina, 2011, p.22), constituindo também entraves à participação dos solicitantes e refugiados como sujeitos do conhecimento. Este exercício reflexivo continuará sendo desenvolvido na próxima seção, na qual discuto o privilégio epistêmico dos “técnicos do refúgio", os obstáculos à participação epistêmica ${ }^{34}$ dos solicitantes e refugiados, bem como a possibilidade de operação de uma injustiça epistêmica testemunhal e hermenêutica.

\section{6}

\section{O GEP e o debate "técnico"}

A última seção deste capítulo busca trazer para o debate o caráter "técnico" atribuído por determinados atores a um momento central nas práticas do refúgio por elegibilidade, reforçando o privilégio epistêmico de avaliar os testemunhos dos solicitantes. Poderemos refletir, assim, sobre a constante produção de um privilégio epistêmico que favorece a participação ativa dos "técnicos do refúgio" enquanto restringe e impede a contribuição dos próprios solicitantes. $\mathrm{O}$ argumento

\footnotetext{
${ }^{34}$ Utilizo o termo "participação epistêmica" como participação nas atividades que Fricker (2007) considera epistêmicas, isto é, na produção/transmissão de conhecimento e na produção de significados/conceitos para fazer sentido das experiências sociais.
} 
desenvolvido aqui é de que este quadro é relevante se queremos refletir sobre a possibilidade de produção de formas de injustiça epistêmica, não só pela relação existente entre déficits e excessos de credibilidade, como também pela constituição de uma posição imerecida de privilégio epistêmico que acaba por marginalizar o conhecimento de determinados sujeitos (Medina, 2011). Além disso, é possível refletir a respeito da ausência de inteligibilidade sobre determinadas experiências sociais, fazendo com que a dimensão hermenêutica da injustiça epistêmica seja trazida à tona pela impossibilidade de imaginar como certa experiência vivida pelo solicitante poderia qualificá-lo como refugiado.

Ainda que não conste na lei brasileira de refúgio como um espaço oficial obrigatório, o chamado Grupo de Estudos Prévios (GEP) tem lugar em Brasília uma vez por mês, a fim de que os membros do CONARE possam discutir de maneira conjunta as solicitações de refúgio e a credibilidade dos solicitantes antes da reunião do plenário do Comitê. Tendo em vista este caráter extra-oficial, nem todos os membros do CONARE estão presentes. José, da Cáritas-SP, me contou em entrevista sobre a participação dos atores nas reuniões do grupo:

Então sentam a mesa né, é uma mesa oval, um representante do ACNUR, nessa ordem... Imagina a mesa: ACNUR, Defensoria Pública, desse lado a irmã Rosita ou o advogado do IMDH, aqui na frente o Bernardo, coordenação [do CONARE], e ele tem um funcionário mais antigo, para quem ele deu funções de elegibilidade, que é o Breno, fica ali com ele auxiliando ele ali. Aqui Polícia Federal, Ministério da saúde normalmente senta aqui entre a DPU e o IMDH, PF, MRE, Cáritas do Rio, Cáritas de São Paulo, na outra fileira fora da mesa sentam os oficiais de elegibilidade que querem assistir, nem sempre ficam o tempo todo [...] (José, Cáritas-SP).

Os membros do GEP reúnem-se para discutir a última pauta elaborada pela coordenação do CONARE (Ministério da Justiça), na qual constam as solicitações de refúgio e os pareceres individuais do oficial de elegibilidade recomendando o deferimento ou indeferimento dos casos. Conforme relatou Camila, da Cáritas-Rio, a dinâmica das reuniões funciona, em geral, da seguinte maneira:

A coordenação [do CONARE] decide por onde começar na pauta, e os membros, as instituições membros da sociedade civil, são chamados a se manifestar, e as outras também. Em geral, primeiro as instituições da sociedade civil e depois as outras instituições. E em geral o parecerista do caso. Os casos para deferimento não são discutidos a menos que haja uma questão em algum caso que seja necessário levantar e tudo mais. Mas em geral a discussão é só sobre indeferimentos e alguma questão necessária a ser discutida, por exemplo, uma nova elaboração de um formulário de solicitação de refúgio [...] E esse é o momento em que existe um diálogo ou um debate sobre os casos (Camila, Cáritas-Rio). 
Adotando uma perspectiva que extrapola a noção do GEP como espaço para debater apenas as decisões dos pareceres de elegibilidade, Fernando, da CáritasRio, me conta como as reuniões são desenvolvidas para que seja possível discutir o que ele chama de "a própria cultura que existe no CONARE", a fim de que os parâmetros ou critérios para a tomada de decisão sejam reavaliados e negociados. Haveria, assim, um espaço coletivo de debates sobre questões mais amplas como, por exemplo, "qual é o limite que o Estado tem para exigir que o solicitante apresente provas". Apesar disso, ainda emerge com destaque o papel da escolha dos casos que vão ser defendidos pelos representantes das instituições e suas estratégias de posicionamento para evitar possíveis desgastes em suas imagens no GEP e no Comitê como um todo.

\begin{abstract}
A primeira tarefa é selecionar estratégias de defesa, que significa ter que inclusive selecionar dentro do contexto quais são as brigas necessárias, quais valem a pena, quais são os casos que você tem chance, quais você não tem, isso tem muitas variáveis né...Tem que saber, assim, da pauta que chegou esse mês, quantos casos a gente pode levantar, quais são os temas, quais são as prioridades. Tem um pouco essa estratégia de pensar... e não é uma questão de perder alguns para ganhar outros, é um pouco um trabalho de não apenas trabalhar para a decisão, para um caso, mas eu acho que também o trabalho no GEP é para decidir sobre o próprio GEP, sobre os parâmetros, sobre a cultura que existe no CONARE, porque ela é de longo prazo [...] Então a gente trabalha também nessa ideia de abrir precedente, de constranger, de convencer, então a gente também vai jogando entre nós assim, quando uma figura nossa está mais desgastada, está com pouco crédito, então é outra pessoa que vai falar ou é substituída (Fernando, Cáritas-Rio).
\end{abstract}

Para Vítor, da DPU de Brasília, as estratégias para as reuniões do GEP envolvem, em grande parte, "pesar: será que vale a pena queimar um cartucho discutindo isso que a gente sabe que vai perder?”. Não seria apenas a credibilidade do solicitante de refúgio que estaria em jogo nas estratégias dos atores no GEP, mas a própria credibilidade da instituição e de seus representantes. Segundo Vítor, "a gente tem que tentar manter um pouco de credibilidade no que a gente fala. Se a gente começar a defender coisas que já defendeu, e perdeu... infelizmente a gente acaba tendo que escolher casos". Apesar da fala do funcionário da Cáritas-Rio sobre as estratégias de alteração das defesas dos casos, para impedir o desgaste exclusivo de um só ator, o funcionário da DPU levanta um cenário de polarização entre esta instituição e a coordenação do CONARE (Ministério da Justiça), que estaria, segundo ele, desgastando a imagem da defensoria no processo. 
Eles [a coordenação do CONARE] estavam mais em uma polarização dentro do GEP, a gente defende o caso e ele defende o parecer, do que num processo de construção e diálogo. A gente estava sentindo muito essa polarização, isso foi identificado dos dois lados, tanto por parte da sociedade civil quando por parte da própria coordenação geral [...] tem essa polarização no GEP: a DPU pega o lado da defesa e faz a defesa quase que isoladamente por ocasião da reunião ordinária e aí continua esse processo de polarização. A DPU fica um pouco estigmatizada por ser quem defende todos os casos, pelo menos os casos relevantes, e isso leva a um desgaste. Eu tenho notado um desgaste da DPU por conta disso, que justificaria talvez a gente ampliar esse leque de defesa de pessoas que pudessem fazer essa defesa. A sociedade civil poderia fazer né, faz pouco, assim, eu acho, é muito próativa no GEP, mas chega na hora da reunião ordinária não tem essa postura (Vítor, DPU de Brasília).

A crítica à polarização entre membros do Comitê no GEP não parte apenas de uma preocupação com o desgaste das instituições e de seus representantes, mas também de uma imagem consolidada do grupo como um espaço de debate técnico. Todos os entrevistados que participam ou já participaram do GEP se referiram ao caráter técnico das discussões, trazendo à tona a perspectiva de que o debate não deve ocorrer em torno de uma divisão entre quem defende o parecer do oficial de elegibilidade e quem defende o solicitante de refúgio. Tal caráter supostamente técnico do GEP seria inclusive o fator que o diferenciaria da reunião oficial do plenário do CONARE. Conforme me contou Vítor, “o cidadão que está sentado ali [na reunião plenária oficial] como membro do CONARE tem um preocupação mais política do que o técnico do refúgio. O técnico do refúgio é um cara técnico que vai trazer argumentos para o deferimento". Cabe ressaltar aqui que esta perspectiva não se restringiu apenas ao funcionário da DPU, mas foi compartilhada por funcionários da Cáritas (RJ e SP). Segundo José, da Cáritas-SP, enquanto na plenária "entra mais o elemento político", no GEP "é uma discussão técnica, a função do GEP é a discussão técnica sobre os casos, óbvio, mas também sobre como os casos são decididos e como eles são analisados".

É um grupo [GEP] que se reúne com antecedência à reunião ordinária e que há efetivamente um debate profundo sobre todos os casos que estão submetidos à reunião ordinária. Então o Grupo de Estudos Prévios é o momento em que as pessoas de fato vão debater, enfim vão selecionar alguns casos e vão debater profundamente aqueles casos para levar esse debate para municiar os membros do CONARE a respeito das discussões que ocorreram, justamente para que eles possam votar com alguma lucidez né, e pautados pela profundidade do debate que ocorre no âmbito do Grupo de Estudos Prévios (Vítor, DPU de Brasília).

O caráter "técnico" do grupo reforça o papel epistemicamente privilegiado de avaliar os testemunhos dos sujeitos que é atribuído aos "técnicos do refúgio. Em 
virtude de treinamentos e suposta expertise no tema, os entrevistados percebem as reuniões do GEP como legítimas e necessárias para que as decisões sejam tomadas "com alguma lucidez", tendo em vista a "profundidade do debate que ocorre no âmbito do Grupo de Estudos Prévios”. As discussões que ocorrem neste espaço giram em torno da avaliação de testemunhos e das diferentes interpretações que os membros do Comitê desenvolvem sobre a credibilidade dos sujeitos, ainda que nenhum deles tenha levantado a importância da presença dos solicitantes de refúgio neste cenário. Quando questionada sobre a possibilidade da presença do solicitante no GEP, Camila, da Cáritas-Rio, afirmou que, durante o período que trabalhou na instituição e atuou nos espaços coletivos com outros membros do Comitê, isso nunca foi discutido. Conforme nos diz Hookway (2010), negar a credibilidade de alguém pode ser uma forma de injustiça epistêmica, mas negar o papel de um sujeito como agente que tem algo a contribuir também pode constituir uma forma de exclusão epistêmica. Nesse sentido, ainda que não possamos falar aqui de um déficit de credibilidade sendo atribuído injustamente, há a produção de um privilégio epistêmico na estruturação de formas específicas de apresentar e compartilhar o conhecimento, favorecendo a discussão dos "técnicos do refúgio" enquanto impede a contribuição dos próprios solicitantes de refúgio.

Poderia haver, assim, uma espécie de objetificação dos solicitantes, com sua exclusão da comunidade de informantes, isto é, dos sujeitos capazes de participar ativamente na produção e no compartilhamento do conhecimento. Fricker (2007) nos ajuda a compreender a questão ao trazer em sua análise uma diferenciação entre a figura do informante (sujeito) e a figura da fonte de informação (objeto). Este último, e como vimos no capítulo teórico, acaba sendo usado somente como objeto de conhecimento, no sentido de que outros sujeitos poderiam usá-lo como uma fonte de informação, mas ele mesmo não participaria ativamente como ator nos espaços de troca testemunhal. A reunião do GEP, do grupo de notáveis "técnicos do refúgio", poderia contribuir, assim, para a exclusão dos solicitantes e refugiados no exercício coletivo de produção e transmissão do conhecimento. Tais sujeitos acabam sendo relegados ao lugar da passividade e da objetificação, a quem os "técnicos do refúgio" recorrem apenas quando desejam sanar possíveis dúvidas em relação a pontos específicos nas narrativas. É possível que haja, nesse cenário, um processo de des-humanização do outro, uma vez que seu status enquanto sujeito de conhecimento é esvaziado com a negação de sua subjetividade (Fricker, 2007). 
A discussão "técnica" sobre os casos e os argumentos para deferimento das solicitações de refúgio perpassam o imaginário e as falas de alguns dos membros mais atuantes no GEP. Entre os esforços para manter a credibilidade das próprias instituições e seus representantes e os esforços para avaliar a credibilidade dos solicitantes de refúgio, os debates procurariam oferecer elementos "técnicos" para analisar os casos em pauta, a partir, por exemplo, de pedidos para novo preenchimento de formulário, de compreensões distintas sobre momentos da entrevista de elegibilidade, e disputas de fontes para embasar decisões sobre a credibilidade externa. Mesmo nesse cenário em que critérios para avaliação dos testemunhos estão em disputa, um defensor da DPU enfatiza como alguns elementos não estão em discussão, uma vez que "quando eles [coordenação do CONARE] identificam contradição interna no discurso da pessoa e aí chegam à conclusão de que não há uma credibilidade interna, fica mais difícil defender". Ainda que possa haver uma dificuldade de compreensão ou questionamento sobre elementos internos da narrativa, o solicitante de refúgio não é chamado a esclarecer possíveis controvérsias, assim como não é aventada a possibilidade da realização de novas entrevistas.

Vítor: As chances de você reverter isso no CONARE, tentar desconstruir o argumento de que o cara, enfim, não está sendo contraditório nesse primeiro momento. E depois no segundo momento tentar caracterizar ainda a situação de refúgio é mais difícil. Porque é um momento da quebra da credibilidade interna... a gente fica um pouco sem saber exatamente qual é a história.

Eu: E é possível retirar o caso da pauta e chamar o solicitante para nova entrevista?

Vítor: Não, isso não tem chance. No CONARE hoje se falar de outra entrevista eles entram em pânico. A gente tem evitado também, aí é um pouco estratégia. A gente tem que ver o caso que vale a pena pedir de novo [...] se em todos que tiver uma contradição a gente pedir uma nova entrevista aí também a gente esvazia um pouco a atuação né. Em alguns casos a gente consegue uma nova entrevista, mas são casos mais assim estratégicos. Isso pelo menos é um critério objetivo que a DPU tem utilizado. Bom, se a gente não consegue superar a credibilidade interna, problema de credibilidade interna, então não vamos defender [...]

José, da Cáritas-SP, também relata como é desenvolvida a sua própria estratégia de atuação no GEP, demonstrando como ele procura questionar problemas de credibilidade interna através da escuta dos áudios da entrevista oficial. Pela sua fala, seria possível discutir supostas incoerências nas narrativas, além das questões de credibilidade externa, ainda que sem a necessidade de recorrer diretamente ao solicitante de refúgio para possíveis esclarecimentos. A 
possibilidade de apelar aos áudios das entrevistas, mas não à participação dos solicitantes nos espaços coletivos de debate, parece apontar para formas mais amplas e estruturais de impedir a participação epistêmica dos sujeitos diretamente interessados no processo. Apesar de o GEP ser uma reunião extra-oficial, não prevista em lei, cuja dinâmica gira em torno das determinações dos próprios envolvidos, os "técnicos do refúgio" parecem perceber como fundamental o acesso à narrativa dos solicitantes, mas os formatos aceitáveis para coletar informações não envolvem o testemunho direto dos sujeitos nos espaços de debate e a transmissão de conhecimento que poderia advir da troca testemunhal.

Então, faço um resumo do caso para todo mundo entender, mostro os motivos do indeferimento e apresento: olha temos informações novas ou é um problema de credibilidade interna, porém isso foi o que aconteceu - eu ouvi o áudio e a gente pode sanar, pelo próprio áudio, sanar esses problemas nos minutos tais e tais, com as informações tais e tais. Ou então: o parecer tem questões de credibilidade externa, mas eu não duvido da credibilidade externa, então... e aí começa a discussão [...] às vezes alguém faz a defesa do parecer: não, o parecer está correto, olha e essa informação aqui... mas não, veja: ele disse isso, isso e isso, isso é o suficiente. E no final a gente chega a uma conclusão (José, Cáritas-SP).

O privilégio epistêmico dos membros do Comitê ficaria evidenciado, assim, "no papel epistemicamente privilegiado de receber, avaliar e decidir sobre testemunhos e interpretações" (Carel e Kidd, 2014, p.16). Nas práticas de privilegiar determinadas posições epistêmicas, um excesso de credibilidade é dado aos sujeitos capazes de fazer julgamentos sobre os testemunhos e decidir seu caráter de verdade. Este cenário importa para a possibilidade de produção de formas de injustiça epistêmica, uma vez que "excessos de credibilidade podem aparecer como uma forma de privilégio epistêmico imerecido que é crucialmente relevante para questões de justiça testemunhal" (Medina, 2011, p.15). Nesse sentido, e segundo Medina, um excesso de credibilidade pode constituir uma injustiça epistêmica já que concede a determinados sujeitos uma condição imerecida de privilégio epistêmico. O grupo de membros do Comitê capazes de saber por uma suposta expertise detém, assim, a legitimidade para o argumento técnico sobre as verdades da condição refugiada. Já os sujeitos em situação marginalizada não podem desfrutar do mesmo privilégio epistêmico, uma vez que sua credibilidade é destruída, seu testemunho ignorado e até seu conhecimento é diminuído por ser considerado insignificante (Hiebert, 2015). 
A partir do trabalho no GEP, desenvolvem-se as disputas dos "técnicos do refúgio" sobre diversas compreensões possíveis nas práticas de avaliação de credibilidade. Em relação ao debate sobre as fontes e sua utilização na análise da credibilidade externa, Vítor, da DPU de Brasília, relatou um exemplo concreto que foi alvo de discussões em reuniões do Comitê:

Nós tivemos um caso de casamento inter-religioso na Índia, o cidadão era hindu e a moça era Muçulmana né, no norte da Índia. Os relatórios internacionais não falavam especificamente de homem Hindu e mulher muçulmana, então o CONARE no início começou a criar muito caso a respeito disso. Os relatórios diziam que, sim, os casamentos inter-religiosos na Índia eram um problema, inclusive no norte do país de onde vinha esse solicitante de refúgio, que estava sendo perseguido por conta do casamento inter-religioso. Mas não havia nada especifico falando de homem e mulher muçulmana. Então nós entendemos que é um preciosismo extremo do CONARE exigir um relatório, já que havia uma informação de que casamento interreligioso em geral seria problemático. Que justiça seja feita, nós fizemos um trabalho de convencimento. Houve entrevistas complementares pela Cáritas-Rio e pelo ACNUR, memoriais foram distribuídos. Nós, enfim, fizemos um trabalho que durou acho que três ou quatro sessões de entrada em pauta de julgamento e retirada para obter mais informações que, no fim, até o próprio CONARE se convenceu né, dessa nossa argumentação. E felizmente foi deferido com unanimidade esse caso, mas houve um pouco esse embate quanto à questão dos relatórios e o que seriam essas informações de origem e qual a profundidade exigida dela (Vítor, DPU de Brasília).

\section{A dificuldade de enquadramento das narrativas aos critérios da lei do refúgio}

também emergiu, nesse contexto, como um tema de debate entre os membros do Comitê, ainda que o parecer do oficial de elegibilidade não tenha sido revertido ao final das discussões. Novamente, o funcionário da DPU trouxe um caso concreto para ilustrar as diferentes perspectivas sobre a condição refugiada:

[...] Um cidadão paraguaio, que teve uma briga com a esposa, e é acusado no Paraguai de violência doméstica, veio para o Brasil. Há um processo de extradição e ele solicitou refúgio dizendo que, na verdade, esse processo que foi instaurado contra ele era manuseado pela esposa que teria influência perante os órgãos de acusação do Paraguai. Nós [DPU] tínhamos informações importantes de que, sim, no Paraguai há um pouco de influência de pessoas poderosas no aparato judicial para manusear processos. Enfim, esse processo foi indeferido justamente porque não se conseguiu imaginar, dentro do CONARE, qual seria o grupo social ao qual ele pertenceria, então é uma condição que aos poucos vai ter que ser feita (Vítor, DPU de Brasília)

No exemplo mencionado acima, os debates dos "técnicos do refúgio" não foram suficientes para reconhecer o solicitante como refugiado, pois os membros do Comitê não conseguiram "imaginar" como a experiência vivida pelo sujeito poderia ser enquadrada nos critérios da lei do refúgio. Ainda que o pertencimento a um grupo social seja explicitamente um critério amplo e flexível que pode incluir sujeitos que vivenciam experiências diversas, os membros do Comitê não teriam 
conseguido compreender a experiência de perseguição do solicitante mencionado neste caso. A presença de um gap nos recursos hermenêuticos coletivos pode impedir, assim, o reconhecimento da condição do solicitante como apropriada à linguagem racional-legal do refúgio. Fricker $(2007,2008)$ nos diz que uma forma de injustiça epistêmica (hermenêutica) pode ser produzida quando alguém tenta, sem sucesso, explicar, por exemplo, uma experiência de assédio sexual quando este conceito ainda não existe nos recursos hermenêuticos coletivos. No caso mencionado pelo defensor, este tipo de injustiça poderia estar sendo produzida, uma vez que ainda não existiria uma inteligibilidade sobre a experiência de ser perseguido por atores influentes das burocracias estatais como algo que pode conectar os sujeitos a uma condição social comum/compartilhada. Na ausência dessa compreensão, não seria possível imaginar como a experiência vivida pelo solicitante o qualificaria como refugiado.

As falas de diferentes entrevistados, situados em instituições distintas, trazem a relevância do GEP como espaço onde determinados atores podem participar coletivamente para debater argumentos expostos nos pareceres de elegibilidade elaborados pelos oficiais da coordenação do CONARE. Considerando esta imagem do grupo como o local onde o debate técnico acontece, alguns funcionários da Cáritas (RJ e SP) e da DPU indicam como preocupação a possibilidade de um esvaziamento da dinâmica em função de posturas identificadas como defensivas. A polarização - de um lado, a coordenação do Comitê defendendo seus pareceres e pareceristas (oficiais de elegibilidade) e, de outro, a sociedade civil em articulação sobre as melhores estratégias de defesa das suas opiniões sobre os casos - estaria levando ao risco de impedir que os "técnicos do refúgio" desenvolvam seus argumentos sobre os critérios que constituem a credibilidade da condição refugiada. O que está em jogo, nesse sentido, é a própria dimensão racional-legal dos processos de elegibilidade, ainda que diversos entrevistados tenham mencionado a existência de estratégias subjetivas de convencimento e até constrangimento em relação à análise dos casos.

É possível compreender, a partir das narrativas dos membros do CONARE, a constante necessidade de reafirmação do GEP como espaço do debate técnico e que, assim, poderia ser diferenciado da reunião ordinária do Comitê (entendida como espaço da dimensão política). Os entrevistados apontam não somente o caráter político da reunião do plenário do CONARE, como também a imagem de 
que a discussão técnica que ocorre no GEP seria apenas uma forma de informar melhor as decisões - que, em última instância, aconteceriam neste momento oficial. Conforme afirmou em entrevista o coordenador do CONARE, "as decisões são tomadas pelo Comitê Nacional para os Refugiados. O GEP é uma reunião prévia para apresentar dúvidas e questionamentos dos casos, às vezes legítimas, às vezes infundadas". Na perspectiva deste entrevistado, entretanto, “O GEP por muitas vezes parece querer substituir o CONARE nas decisões, querendo transformar o Comitê em apenas um cartório para referendar sugestões feitas pelo GEP. Mas não pode e nem funciona desse jeito". Apesar da preocupação exposta pelo coordenador do Comitê sobre o papel do GEP no processo de elegibilidade, todos os membros entrevistados salientaram que a decisão ${ }^{35}$ ocorre na reunião oficial e que o grupo apenas "apresenta as informações técnicas para subsidiar a plenária", conforme afirmou José, da Cáritas-SP.

\section{7 \\ Conclusões}

Busquei discutir neste capítulo o processo de formação da burocracia da elegibilidade em suas práticas complexas de determinação do status de refugiado. Para tanto, abordei como o processo é percebido e construído pelos seus diversos atores do ponto de vista formal, detalhando os rituais de preenchimento do formulário de solicitação de refúgio, as entrevistas com oficiais do CONARE, as discussões sobre a credibilidade dos solicitantes de refúgio e, por fim, o espaço do GEP para argumentação coletiva sobre os casos. A partir disso, procurei ressaltar como as diferentes etapas analisadas aqui apresentam dois pontos em comum fundamentais nas dinâmicas da injustiça epistêmica: 1) um gradual desaparecimento dos solicitantes no processo, com a desapropriação das narrativas e obstáculos a sua participação e 2) o papel central de uma "economia da credibilidade" (Fricker, 2007) afetada por preconceitos e estereótipos, bem como pela relação entre excessos e déficits de credibilidade. Vimos, então, uma série de restrições ao conhecimento dos solicitantes e refugiados e entraves a sua participação no processo, ao mesmo tempo em que determinados sujeitos, como os

\footnotetext{
${ }^{35}$ Para um debate aprofundado sobre a tomada de decisão no processo brasileiro de refúgio, ver Magalhães (2014, 2016).
} 
"técnicos do refúgio", desfrutam de um privilégio epistêmico fundamental em termos de produção de injustiça epistêmica no refúgio por elegibilidade.

Nos rituais de preenchimento do formulário de solicitação de refúgio, emerge uma série de obstáculos à circulação do conhecimento do solicitante, convocado a testemunhar suas experiências obedecendo a determinados estilos de narrativa e modos de compartilhamento. O conhecimento do solicitante é gradualmente substituído pela expertise da orientação sobre o enquadramento do seu testemunho à lei do refúgio, enquanto os solicitantes são vistos como aqueles capazes de ler, mas não de compreender o que está escrito no documento. O testemunho do solicitante é visto como insuficiente ou inadequado para a linguagem da burocracia e, com isso, "o conhecimento que seria transmitido ao interlocutor não é recebido" (Fricker, 2007, p.43). A visão de que alguns solicitantes seriam "analfabetos funcionais" não precisa ser compreendida como uma postura consciente ou mal-intencionada - pelo contrário, a perspectiva dos atores envolvidos no ritual parece apontar para um desejo de ajudar os sujeitos a atravessar a burocracia do processo. Porém, mesmo uma conduta discriminatória inconsciente pode levar a uma prática de desacreditar o outro por sua suposta incompetência e, nesse sentido, a postura de não levar a sério a habilidade do sujeito em prover conhecimento em determinado contexto pode produzir um quadro de injustiça epistêmica (Anderson, 2012; Hookway, 2010).

Nas entrevistas de elegibilidade, a preocupação com o caráter de verdade das narrativas ajuda a constituir a troca testemunhal como uma prática investigativa que busca "extrair informações" e "mapear a pessoa". A extração de informações, o mapeamento e a penetração do sujeito emergem como um complexo de práticas investigativas relacionadas à percepção de que a credibilidade do solicitante independe da troca testemunhal e, assim, não seria atribuída pelo seu interlocutor, mas estaria contida no sujeito - ou simplesmente ausente, pois "o relato não conseguia ter credibilidade em si mesmo". A concepção da credibilidade do sujeito como algo independente da troca testemunhal não considera que uma "economia da credibilidade" (Fricker, 2007) pressupõe a interação entre indivíduos e a comparação entre eles. No quadro de uma injustiça epistêmica testemunhal, é fundamental ter em mente que os excessos de credibilidade desempenham papel importante na produção de injustiças (Medina, 2011). Nos rituais da entrevista, a autoridade epistêmica do oficial é revelada não só pela sua suposta capacidade de 
avaliar as narrativas dos solicitantes, cada vez mais relegados ao papel passivo de sujeito investigado, como também pelo apagamento da sua própria presença (subjetiva) no processo de esvaziar ou atribuir credibilidade.

No decorrer do processo, torna-se mais difícil apagar a presença dos atores responsáveis por avaliar a credibilidade dos solicitantes de refúgio e, portanto, de determinar a força ou a fraqueza dos casos. A análise das práticas da elegibilidade no universo do refúgio permite compreender como uma "economia da credibilidade" (Fricker, 2007) diz respeito "aos modos pelos quais a credibilidade é distribuída de forma desigual entre diferentes sujeitos" (McKinnon, 2016, p.438). O privilégio epistêmico de determinados atores cria as condições de possibilidade para a imagem da credibilidade interna como algo dado e independente das trocas testemunhais. A fim de que seja possível refletir sobre a produção de uma injustiça epistêmica nas práticas do refúgio por elegibilidade é necessário analisar a atribuição de excessos de credibilidade aos atores responsáveis por julgar comportamentos, plausibilidade, coerência e consistência dos testemunhos e seus sujeitos. Torna-se possível, então, compreender como "o excesso de autoridade epistêmica de alguns constitui uma injustiça diretamente relacionada ao déficit de credibilidade de outros" (Medina, 2011, p.22).

Por fim, mas não menos importante, a análise do chamado Grupo de Estudos Prévios (GEP) trouxe à tona a imagem dos "técnicos do refúgio" reunidos para debater os termos e critérios para a identificação da condição refugiada. Embora a menção a estratégias de convencimento e constrangimento dos atores tenha atravessado algumas falas sobre o GEP, o que sobressaiu das entrevistas foi a compreensão dos sujeitos sobre a importância do especialista responsável por avaliar a credibilidade e elementos mais amplos que constituem o que pode ou não ser levado em consideração na determinação do status. No interior do processo de elegibilidade estaria, então, este grupo dos "notáveis" capazes de saber pela expertise, disputando as compreensões a partir de argumentos técnicos sobre credibilidade. Tais atores desfrutam, assim, de um "papel epistemicamente privilegiado de receber, avaliar e decidir sobre testemunhos e interpretações" (Carel e Kidd, 2014, p.16), sendo dotados de um excesso de credibilidade que pode permitir a produção de formas epistêmicas de injustiça.

Enquanto este capítulo buscou dar conta do processo de formação da burocracia da elegibilidade, ressaltando e contextualizando dinâmicas formais 
importantes, o próximo capítulo está voltado à tentativa de abordar os aspectos mais subjetivos do processo. Considero, nesse sentido, que o exercício de compreender as condições de possibilidade para a produção de uma injustiça epistêmica também passa pela tarefa de refletir sobre uma rede complexa de práticas da elegibilidade neste cenário. Buscarei analisar, dentre outras coisas, os esforços de gerenciar expectativas no processo, vencer incoerências nas narrativas e convencer o outro, bem como o papel da (des) confiança e o sentimento sobre as "histórias de refúgio". Ainda que tenha sugerido no decorrer da discussão anterior a presença de tais questões no processo, o próximo capítulo reunirá de maneira concentrada as reflexões sobre uma gestão dos aspectos subjetivos do universo institucional do refúgio e o que isso pode significar em termos de produção de injustiças. 


\section{4 \\ As práticas do refúgio por elegibilidade no Brasil: Percepções subjetivas e injustiça epistêmica}

\section{Resumo}

O presente capítulo busca analisar as práticas do refúgio por elegibilidade no Brasil a partir da dimensão das percepções subjetivas, trazendo para a discussão como os diferentes sujeitos percebem o processo de determinação da condição refugiada e sua participação nele. Para além da formação da burocracia da elegibilidade, já abordada no capítulo anterior, procuro refletir detalhadamente aqui sobre o caráter subjetivo das análises de credibilidade e da determinação do status de refugiado. Com isso em mente, o objetivo do capítulo é trazer à tona como os diferentes atores percebem seu papel no gerenciamento de expectativas, na busca por vencer incoerências e convencer o outro, no exercício da (des) confiança, na gestão das emoções sobre as "histórias de refúgio" e na articulação de diferentes significados sobre o que constitui a condição refugiada. Permanece como fio condutor a análise das condições de possibilidade para a produção de uma injustiça epistêmica nas práticas da elegibilidade.

Palavras-chave: Elegibilidade; Subjetividade; Injustiça Epistêmica.

\section{1 Introdução}

O processo de elegibilidade no Brasil busca proteger o instituto do refúgio de "contaminações" de outros sujeitos migrantes. Em outras palavras, facilmente escutadas neste campo, é preciso impedir o uso abusivo e indevido da condição refugiada. Nesse sentido, a análise de credibilidade é uma das tarefas mais primordiais do processo de elegibilidade (ACNUR, 2013; Cameron, 2010; Kagan, 2003; Magalhães, 2016; Sweeney, 2009). Tendo em vista que, em geral, o solicitante de refúgio não possui documentos que comprovem sua narrativa de fundado temor de perseguição, a tarefa de determinar se o sujeito é, de fato, um refugiado recai sobre uma rede de atores que compõem o CONARE. Os membros do Comitê buscam determinar, de forma coletiva, se o testemunho é consistente com os fatos objetivos conhecidos sobre o país de origem e se há elementos de consistência interna e plausibilidade expostos pelo solicitante ao narrar sua história (ACNUR, 1998; Kagan, 2003). A determinação da condição refugiada emerge, assim, como produto de uma rede complexa de interações entre diferentes membros 
do CONARE e entre estes e os solicitantes de refúgio - ainda que a participação desses últimos esteja restrita a "ocasiões em que ele [o solicitante] é convocado a relatar", conforme afirmou em entrevista Fernando, da Cáritas-Rio.

Parte significativa do processo de elegibilidade é composta por uma gramática legal-burocrática que define critérios de autenticidade e legitima pareceres oficiais da coordenação do CONARE, ajudando também a constituir a dinâmica da determinação da condição refugiada a partir da idéia de um debate técnico sobre a validade das solicitações de refúgio. A partir dessa imagem racional do processo, instituições representantes da sociedade civil adaptam e organizam suas práticas diárias, membros do CONARE debatem e fundamentam posições no Grupo de Estudos Prévios (GEP), recursos contra solicitações indeferidas são interpostos, reuniões de formação dos atores que constituem o universo institucional do refúgio são realizadas e decisões são legitimadas. As diversas etapas e dinâmicas do processo, como o preenchimento do formulário de solicitação do refúgio, a entrevista com o oficial de elegibilidade, a discussão sobre a força ou fraqueza dos casos, e a participação dos membros do Comitê no GEP, emergem atravessadas pela racionalidade da burocracia. O grupo dos "técnicos do refúgio" atuaria a partir de "argumentos técnicos" sobre a credibilidade das solicitações de refúgio e seus sujeitos, conforme vimos no capítulo anterior.

Apesar da imagem objetiva do refúgio por elegibilidade, apresentada em maior ou menor grau de acordo com o sujeito entrevistado, as falas dos membros do CONARE também podem ser compreendidas como estando atravessadas por uma dimensão subjetiva importante. Em muitas entrevistas, a idéia de um feeling sobre a credibilidade do solicitante e do seu testemunho ocupa espaço central, assim como a necessidade que os sujeitos percebem em gerenciar expectativas, vencer incoerências e convencer o outro. Aos poucos, conforme os atores desenvolvem suas perspectivas, a imagem racional e objetiva do processo se vê lado a lado com uma gestão complexa da dimensão subjetiva nas práticas da elegibilidade. Ainda que seja difícil separar essas dimensões, imbricadas nos imaginários dos atores e nas suas condutas, procuro oferecer uma análise que constrói uma versão em alguma medida didática do processo, mesmo que já tenha deixado transparecer no capítulo anterior como a subjetividade afeta as avaliações sobre os testemunhos dos solicitantes. De forma mais detalhada, busco me deter aqui sobre como as práticas da elegibilidade envolvem uma dimensão importante da ordem das percepções 
subjetivas, no sentido de como o sujeito é afetado pela relação com o outro. Conforme Fernando, da Cáritas-Rio, me disse em entrevista, muito do que acontece no refúgio por elegibilidade envolve o "nível afetivo de compreender quais são os problemas que a pessoa passa e os tipos de coisas que elas contam. Não tem uma posição que você fique de isenção, neutralidade, tem uma afetação o tempo inteiro. E isso é muito forte".

Busco refletir sobre as práticas da elegibilidade, em suas dimensões objetiva e subjetiva, a fim de que seja possível compreender as condições de possibilidade para a produção de uma injustiça epistêmica nesse cenário. O refúgio por elegibilidade, operado através de um processo que analisa a credibilidade dos solicitantes e seus testemunhos, permite que analisemos a importância das suas práticas diárias básicas e a possível produção de injustiças. No capítulo anterior, discuti algumas dinâmicas burocráticas do processo à luz do debate teórico no campo da injustiça epistêmica, enfatizando questões como: a existência de uma posição epistêmica privilegiada, a produção de excessos de credibilidade e a presença de obstáculos à transmissão do conhecimento por parte do solicitante de refúgio. No presente capítulo, almejo refletir sobre a possibilidade de produção de uma injustiça epistêmica relacionada à dimensão subjetiva que os atores trazem ao processo, o que faz emergir, dentre outras coisas, o papel de sentimentos e percepções na busca por atribuir ou esvaziar credibilidade. A partir dessa discussão, podemos compreender que relações de (des) confiança e o caráter subjetivo das diferentes interações importam para nossa epistemologia, mas não se restringem a ela, uma vez que impactam a vida daqueles que solicitam refúgio no Brasil.

As entrevistas realizadas com diferentes membros do CONARE, e com solicitantes de refúgio e refugiados, constituem o material a partir do qual realizo as análises expostas aqui. Tendo isso em mente, procuro refletir, em um primeiro momento, sobre a perspectiva de diferentes atores em relação ao papel que desempenham no gerenciamento das expectativas no processo de elegibilidade. Haveria, nesse sentido, uma "cultura do CONARE" a ser traduzida aos solicitantes de refúgio em entrevistas preparatórias realizadas antes da entrevista com o oficial de elegibilidade. A partir deste cenário, é possível perceber não somente a existência de uma posição epistêmica privilegiada, tema que analisei detalhadamente no capítulo anterior, mas também a busca por encaixar os 
testemunhos às diversas expectativas existentes e por realizar inferências a respeito da confiabilidade dos sujeitos.

Em seguida, discuto a percepção de diferentes atores sobre o trabalho de vencer incoerências nas narrativas dos solicitantes e a necessidade de convencimento de outros membros do Comitê - convencimento esse que não deve ser realizado apenas pelo solicitante, mas também por funcionários das instituições desse universo. Há, assim, uma premissa fundamental que parece circular entre as perspectivas dos entrevistados e que diz respeito à existência de incoerências nos testemunhos dos solicitantes de refúgio, fazendo emergir a necessidade de gerenciar as narrativas para superar "pontas soltas". Já no que se refere à busca por convencimento, é possível perceber como este processo envolve uma distinção significativa realizada pelos funcionários: o solicitante deve ser capaz de prover imagens a partir de seus testemunhos que afetem e impactem o oficial, enquanto outros membros do Comitê devem empreender um trabalho objetivo e racional de convencimento dos outros atores envolvidos no processo de elegibilidade.

$\mathrm{Na}$ terceira seção procuro analisar o papel da (des) confiança no processo e seu caráter intrinsecamente subjetivo, refletindo sobre a concepção de que um ambiente de confiança seria necessário para que o solicitante pudesse narrar sua história, ainda que não tenha emergido das falas a necessidade de estabelecer um vínculo de confiança do oficial no solicitante. Tal discussão abre caminho para a análise posterior, relacionada à gestão das emoções no que diz respeito às "histórias de refúgio", em que procuro refletir sobre o papel central que o sentimento, ou a percepção subjetiva, desempenha nos julgamentos de credibilidade e no processo decisório como um todo. Os critérios mencionados para a realização das análises de credibilidade passam a apontar, assim, para uma espécie de feeling sobre a autenticidade dos sujeitos e de suas solicitações de refúgio, com a concomitante busca por ser afetado pelos testemunhos a fim de que seja possível tomar uma decisão.

Por fim, irei analisar na última seção a emergência de uma pluralidade de significados distintos atribuídos à figura do refugiado, levantando a possibilidade de que estas concepções dificultam uma troca testemunhal inteligível sobre a experiência social dos sujeitos em situação de refúgio. Também procurarei trazer para o texto as diferentes concepções elaboradas pelos próprios solicitantes e refugiados sobre a condição do refúgio, bem como o debate crítico que emerge a 
partir de suas falas a respeito da existência de uma série de preconceitos e estereótipos que permeiam suas relações com alguns brasileiros.

De maneira geral, é possível observar a manutenção de uma estrutura em que a confiança na capacidade explicativa de determinados atores institucionais é acompanhada por uma desconfiança na capacidade de produção e transmissão do conhecimento dos solicitantes e refugiados, indicando não somente a sua marginalização, como também a possibilidade de produção de uma injustiça testemunhal e hermenêutica. Neste quadro, ganha destaque o papel central que percepções subjetivas desempenham no processo de avaliar a credibilidade dos solicitantes, fazendo com que seja possível compreender como a economia da credibilidade pode ser impactada não somente pela circulação de preconceitos e estereótipos, mas também por reações emocionais na troca com o outro. Dessa maneira, assim como no capítulo anterior, é possível compreender tanto a existência de uma restrição ao conhecimento dos solicitantes e refugiados, com obstáculos a sua participação ativa nas práticas da elegibilidade, quanto à importância de uma "economia da credibilidade" (Fricker, 2007) mediada pelos atores em posições de privilégio epistêmico. Diferentemente do capítulo anterior, porém, busco me deter aqui sobre os aspectos subjetivos que impactam o processo e trazem à tona o papel das emoções e percepções na possibilidade de produção de uma injustiça epistêmica.

\section{2 \\ O gerenciamento das expectativas no processo}

No decorrer desta seção trabalharei a perspectiva amplamente mencionada pelos entrevistados a respeito da necessidade do gerenciamento das expectativas no processo de elegibilidade. Buscarei contribuir para compreensões acerca das práticas voltadas à introdução dos solicitantes de refúgio à "cultura do CONARE", entendida aqui como um conjunto de expectativas que circulam entre os membros do Comitê. A condução de entrevistas preparatórias, antes da entrevista com o oficial de elegibilidade, traz à tona não somente a existência de uma posição de privilégio epistêmico, já amplamente discutida no capítulo anterior, mas também a realização de inferências sobre a confiabilidade dos sujeitos, o papel da expertise e a exclusão do conhecimento dos solicitantes de refúgio. Argumento, com Carel e 
Kidd (2014), que a aceitação de estruturas injustas pode configurar uma forma de injustiça epistêmica. Em outras palavras, a manutenção de uma estrutura em que é exercida a confiança na capacidade explicativa dos sujeitos bem posicionados epistemicamente está atravessada pela desconfiança na capacidade de produção e transmissão do conhecimento por aqueles impedidos de desfrutar da mesma posição de privilégio epistêmico, contribuindo para um quadro de produção de injustiça testemunhal.

Ainda que, em um primeiro momento, pensemos sobre a expectativa do solicitante de refúgio ou do refugiado sobre seu processo, as falas dos entrevistados apontam em conjunto para as expectativas existentes por parte dos membros do CONARE. Nesse sentido, a perspectiva exposta pelos sujeitos está em sintonia com a idéia de que, a fim de que seja possível navegar o processo de elegibilidade, o solicitante precisa ser orientado sobre o que diferentes atores esperam da sua figura nas práticas de determinação do status de refugiado. Tal visão ajuda, ainda, a legitimar o trabalho realizado pelas instituições que representam a sociedade civil no Comitê. A perspectiva de que seria preciso gerenciar expectativas é exposta em diversas menções dos atores às suas práticas de orientação do solicitante de refúgio para entrevistas com o oficial de elegibilidade do CONARE, trazendo a visão de que o sujeito que busca refúgio também deve estar informado das expectativas dos atores responsáveis por avaliar sua solicitação. Fernando, da Cáritas-Rio, me contou sobre como percebe o papel da instituição nesse contexto:

Eu acho que é entender um pouco o que é o trabalho. É um trabalho de tradução, traduzir para essa pessoa uma cultura da burocracia do sistema de refúgio, explicar qual a expectativa que tem, quais são os pressupostos. Não existe um processo que tenha uma neutralidade dada, existem pressupostos, existem atores e o que eles imaginam. É antecipar isso para a pessoa para que ela, nas suas repostas, tenha a visão desse jogo. Porque o que é muito injusto no processo é ocultar essa assimetria né, ou seja, basta você dizer a verdade, é o que o CONARE e o próprio ACNUR, em algumas ocasiões disse: dizer a verdade, explicar, e está tudo bem. Não está tudo bem (Fernando, Cáritas-Rio).

A existência de uma "cultura do CONARE", conforme relatou o mesmo entrevistado, é entendida como aquilo que precisa ser traduzido para o solicitante de refúgio, geralmente pelo funcionário da Cáritas, mas também por aqueles refugiados que já atravessaram o processo e podem atuar como intérpretes ou auxiliares dos novos solicitantes. Haveria, assim, a necessidade de introduzir o solicitante de refúgio neste conjunto de expectativas que circulam entre os membros 
do Comitê, a fim de que o sujeito possa compreender as perspectivas dos responsáveis pela tomada de decisão. Ainda que a fala do entrevistado traga a importância de estabelecer uma "zona de comunicação" em que o funcionário também compreenda as diferentes visões dos solicitantes, parece sobressair em sua narrativa um processo de tradução que precisa ser feito para que o solicitante entenda o processo de elegibilidade.

Durante uma entrevista o solicitante se explica, mas ele não é capaz de dar grandes explicações, então às vezes essas pessoas ajudam porque sabem mais, porque estudaram, pesquisaram, e também porque eles vão entendendo como é essa cultura. A cultura do CONARE, porque é como eu dizia né, que o nosso papel é traduzir para eles qual a expectativa, qual o ponto de vista do Estado a respeito do processo, mas também o aprendizado que a gente faz, é conseguir entender como eles pensam, como eles veem aquilo, o que eles acham desse processo. Porque é muito mais difícil do que entender o Estado, assim, para tentar uma zona comum de comunicação, acho que o grande desafio é esse, é conseguir essa zona de comunicação em que os envolvidos se entendam. Porque os termos são muitos diferentes, cada um pensa o que é guerra, o que é perseguição, o que é violação, o que é burocracia (Fernando, Cáritas-Rio, grifo meu).

Embora a fala do entrevistado levante a importância de estabelecer um diálogo com os solicitantes de refúgio, buscando compreender suas distintas percepções sobre guerra, perseguição e violação, por exemplo, este trecho da entrevista também traz a possibilidade de debate sobre uma posição de privilégio epistêmico por parte de alguns atores no processo. A premissa de que certos atores seriam mais capacitados para "traduzir" a "cultura do CONARE" ao solicitante lança luz sobre a existência de uma melhor posição epistêmica em que determinados sujeitos estariam a fim de compreender o processo de elegibilidade. Conforme nos diz o entrevistado, não é apenas o funcionário/voluntário da instituição que teria melhores condições de saber o que esperam os membros do Comitê, mas também o refugiado-intérprete ${ }^{36}$ que teria maior conhecimento não só dos assuntos do seu

\footnotetext{
${ }^{36}$ Termo livremente elaborado por mim para fazer referência ao refugiado que, já tendo passado pelo processo, compreende bem a chamada "cultura do CONARE" e os fatos sócio-políticos de seu país de origem, ajudando outros solicitantes de refúgio a navegar os procedimentos da elegibilidade. Em outras palavras, poderíamos dizer que é o sujeito que ajuda nas transições entre o universo burocrático do refúgio e o universo da experiência vivida pelo solicitante. Embora eu tenha feito referência ao papel do refugiado-intérprete como alguém considerado em posição epistêmica melhor, quando comparado ao solicitante que desconhece os meandros da elegibilidade, é preciso ter em mente como essa figura pode ser mobilizada na tentativa de tornar o processo mais palatável. Nesse sentido, a mobilização do refugiado-intérprete pode ser feita a fim de diminuir a injustiça epistêmica que pode ocorrer no processo, aumentando a possibilidade de uma troca testemunhal inteligível entre os solicitantes e os refugiados que possuem maior conhecimento nas práticas de determinação do status.
} 
país, mas também da cultura institucional existente neste universo do refúgio no Brasil.

A afirmação de que "ele [o solicitante] não é capaz de dar grandes explicações" parece apontar não necessariamente para a operação de um preconceito que diminui a credibilidade do testemunho do solicitante de refúgio, mas para a existência de "inferências sobre a confiabilidade do sujeito" (Origgi, 2012, p.227). Ampliando a perspectiva teórica originalmente proposta por Fricker (2007), Origgi nos diz que o preconceito não esgota o caso de uma injustiça testemunhal, já que mecanismos cognitivos, culturais e sociais podem afetar a prática epistêmica da confiança. Para a autora, um dos mecanismos mais comuns que pode nos fazer cometer uma injustiça testemunhal é a inferência feita a respeito da confiabilidade do sujeito como informante. É possível inferir a confiabilidade de um informante ao julgar sua posição epistêmica. Origgi nos dá um exemplo simples para entendermos o argumento: "se eu ligo para minha irmã para saber a previsão do tempo em Milão, a cidade onde ela mora, eu confio nela porque estou apta a inferir sua confiabilidade nesse contexto, tendo em vista sua melhor posição epistêmica" (Origgi, 2012, p.228). Da mesma forma, recorrer ao ator que possui conhecimento acerca das expectativas sobre os tipos de testemunho adequados ao refúgio por elegibilidade ou, ainda, acessar o refugiado-intérprete que também teria mais conhecimento sobre as questões políticas e sociais em seu país de origem, pode ser compreendido como uma inferência a respeito de quem está em melhor posição epistêmica neste cenário.

Embora possamos julgar evidente a importância de informar o solicitante de refúgio a respeito das expectativas existentes por parte dos membros do Comitê que decidirão o seu pedido, o que parece relevante destacar aqui é não só a existência de uma posição epistêmica privilegiada por parte de alguns atores, mas também o que a simples reafirmação desta condição pode implicar em termos de produção do conhecimento. Ao afirmar que o solicitante de refúgio se explica em uma entrevista, "mas ele não é capaz de dar grandes explicações", o entrevistado reforça não apenas a existência de uma posição de privilégio epistêmico que permite que outros sujeitos estejam melhor situados para oferecer a narrativa esperada pelo processo, mas também o papel da expertise. Conforme nos diz Origgi, a avaliação da confiabilidade do sujeito também pode passar pela expertise adquirida em determinado assunto. Neste contexto, apenas aqueles que compreendem a "cultura 
do CONARE" seriam capazes de oferecer "grandes explicações" adequadas à narrativa do refúgio e seu vocabulário específico de perseguição. Confiar na capacidade explicativa dos sujeitos bem posicionados epistemicamente é, ao mesmo tempo, desconfiar da capacidade de produção e transmissão do conhecimento por aqueles que estão impedidos de desfrutar da mesma posição, podendo contribuir para reforçar ou manter um quadro de injustiça testemunhal.

No decorrer da entrevista com o funcionário da Cáritas-Rio, vai se tornando clara a importância da entrevista conduzida pelo setor de proteção legal e elegibilidade da instituição, entendida como uma espécie de preparação para a entrevista com o oficial de elegibilidade do CONARE. Esta prática é entendida como estando voltada para "ouvir e preparar" o solicitante, o que não significa ajudá-lo a produzir narrativas falsas sobre um fundado temor de perseguição. Conforme me contou o funcionário, "não é ajudando a inventar mentiras, não, mas explicando o que vai acontecer, ouvindo a narrativa, apontando quais são os elementos fracos, os elementos fortes da narrativa dessa pessoa, ajudando ela a pesquisar, esse tipo de coisa". Outros atores também buscaram explicar o que é e como funciona a entrevista preparatória que ocorre na instituição, também se esforçando para diferenciá-la da entrevista oficial:

Maria: Na entrevista o primeiro passo é sempre a gente tentar explicar, tentar deixar bem claro as diferenças, separar as instituições: olha essa não é a entrevista de elegibilidade no CONARE, a entrevista oficial vai acontecer no CONARE, você está na Cáritas, que é uma instituição da sociedade civil. Tudo isso a gente fala, a gente passa inclusive pela definição do refúgio, a gente explica normalmente no momento do preenchimento do formulário, mas também na entrevista como que acontece o processo de solicitação de refúgio, as etapas, formulários, entrevista e o objetivo da entrevista. A gente explica sempre que são dois: primeiro, preparar a pessoa para a entrevista no CONARE, segundo, a gente conhecer o caso, para caso a gente precise defender mais pra frente.

Eu: Então ele [o solicitante] sabe que tem esses espaços, por exemplo, do GEP, da Plenária, e que a Cáritas participa para defender ou não o caso dele? Esses momentos são mencionados?

Maria: Esses momentos institucionais não são mencionados. Na entrevista normalmente a gente explica mais ou menos o que vai acontecer na entrevista de elegibilidade e pede para a pessoa contar a história dela, da vida dela, sempre orientando a manter a ordem cronológica, a fornecer o máximo possível de detalhes, não entrar em contradição e então a gente sempre vai apontar quando houver uma contradição para a pessoa trabalhar melhor a história.

A expertise do funcionário sobre as etapas e mecanismos decisórios do processo de elegibilidade parece ser mantida pelo que compreendo do trecho da 
entrevista. Apesar da existência de um conhecimento desigual sobre o processo, que pode impactar diretamente o solicitante de refúgio, os momentos institucionais não seriam mencionados neste diálogo preparatório para a entrevista oficial. Não somente os espaços coletivos de decisão estariam ausentes da explicação sobre o processo, como também a implicação da Cáritas nas práticas decisórias - deixando de lado o duplo papel da instituição que, ao mesmo tempo em que orienta e prepara o solicitante de refúgio para a entrevista de elegibilidade, também avalia e decide sobre o mérito do seu pedido. Apesar da ausência de menções às instâncias decisórias, a funcionária da Cáritas-Rio busca orientar o solicitante a respeito das expectativas sobre seu testemunho, indicando a importância de elementos como a cronologia dos fatos narrados, nível de detalhes e consistência interna. O funcionário/voluntário é responsável, então, por orientar o sujeito e também identificar em seu testemunho as supostas contradições que precisariam ser corrigidas. Nesse sentido, determinados atores do processo não são apenas privilegiados epistemicamente por seu treinamento, expertise e inserção no Comitê, mas também parecem não reconhecer a importância da diminuição do gap em oportunidades de informar ao solicitante sobre as práticas de avaliação conjunta de credibilidade.

Camila, da Cáritas-Rio, apresentou uma perspectiva diferente sobre como eram conduzidas as entrevistas, relatando sua busca pessoal por explicar também os espaços coletivos de argumentação e deliberação sobre os casos, além da menção ao papel da própria instituição nesse processo. Embora seja fundamental trazer para a análise a existência de diferentes práticas e perspectivas sobre a condução dos momentos de troca testemunhal com o solicitante de refúgio, a existência dessa discrepância também levanta a possibilidade de um cenário discricionário, em que cada ator decide, de maneira subjetiva, como deseja entrevistar os solicitantes.

Eram entrevistas sobre, mais ou menos uma orientação sobre o processo, às vezes duravam em média uma hora, ou uma hora e pouco, dependendo da entrevista, é claro, dependendo do que a pessoa quisesse falar, evidentemente também. A gente orientava como funcionava o processo, então eu explicava a atuação da Cáritas, explicava a atuação do CONARE, explicava quanto tempo durava o processo mais ou menos, em quanto tempo eles fariam uma entrevista com o CONARE, explicava o que é essa entrevista com o CONARE, que é uma parte da instrução do processo deles, explicava como que funciona depois da entrevista com o CONARE, no sentido de julgamento, como que seria avaliado esse caso, o que é um parecer, que é instruído pela coordenação do CONARE, que é votado, que é discutido numa reunião anterior a uma plenária onde se vota esse parecer, que a Cáritas tem o direito de voto em relação a esse parecer, isso eu explicava também [...] (Camila, Cáritas-Rio). 
Ainda segundo Camila, mencionar sua própria expectativa sobre o testemunho do solicitante de refúgio e o que ela mesma gostaria de ouvir deste sujeito era importante a fim de que "fosse mais fácil para ele construir uma narrativa útil para a entrevista dele, para o processo dele". A utilidade da narrativa era explicada, de acordo com Camila, não só em termos de uma preparação para a entrevista oficial, mas também tendo em vista o direito de voto da Cáritas no processo e sua participação em espaços como o GEP. Para a entrevistada, a troca com os solicitantes de refúgio a respeito das expectativas existentes extrapolava o momento da entrevista na instituição e atravessava outros espaços coletivos criados, nos quais havia uma conversa entre os solicitantes e os funcionários/voluntários do setor de proteção legal e elegibilidade. Nestes grupos $^{37}$ seria possível, então, trabalhar as expectativas do processo, explicar como funciona a análise de credibilidade, o que seria ou não perguntado na entrevista oficial e o que o CONARE esperava das narrativas.

A cronologia como algo que normalmente era perguntado, mas que eles poderiam dizer também: eu não me lembro, eu passei por isso logo antes, depois disso eu não tenho lembrança, eu não sei como eu cheguei exatamente nessa região, eu desmaiei. Enfim, explicava que também era algo que poderia ser dito: eu vi minha comunidade ser massacrada, eu cheguei aqui e eu não sei quanto tempo demorei, mas eu tenho uma estimativa de que eu demorei tanto tempo. Às vezes a gente tentava fazer com que eles procurassem reconstituir o máximo possível, porque com certeza eles seriam perguntados infinitas vezes e eles [oficiais de elegibilidade do CONARE] pediriam infinitas vezes para eles reconstituírem a narrativa né, fariam perguntas. Explicava como é que é a análise de credibilidade, que eles fazem pergunta de um momento do tempo e depois de outro momento do tempo, depois volta e refazem as perguntas para ver se eles entram em contradição, se existe uma incoerência e tudo o mais, então era basicamente isso (Camila, Cáritas-Rio).

A fala da Camila traz novamente à tona algumas dimensões importantes na análise de credibilidade no processo brasileiro de refúgio, como a cronologia, o detalhamento das narrativas e a consistência interna, trabalhados exaustivamente no capítulo anterior. Embora sua intervenção possa ser compreendida como fundamental para que o solicitante seja informado a respeito da possibilidade de, por exemplo, explicar ao oficial de elegibilidade o motivo de possíveis dificuldades com a cronologia ou memória dos eventos, há também uma dimensão estrutural

\footnotetext{
${ }^{37}$ Os chamados grupos de elegibilidade foram relatados como reuniões esporádicas, não obrigatórias, que aconteciam conforme a possibilidade de organização do trabalho por parte dos funcionários e voluntários da Cáritas-Rio e a presença de solicitantes interessados nas discussões.
} 
relevante que pode ser mencionada aqui. O esforço por fazer com que o solicitante entenda as expectativas acerca dos estilos e formatos narrativos adequados nos quais uma "história de refúgio" deve ser contada reforça a existência dessa estrutura. Nesse sentido, a busca por adaptar o testemunho do solicitante a um modelo ideal a fim de que ele passe no teste da coerência, por exemplo, pode fazer com que os modos pré-determinados de estabelecer a figura da narrativa ideal permaneçam sem questionamento. Conforme nos dizem Carel e Kidd (2014), também pode configurar uma forma de injustiça epistêmica a aceitação de estruturas epistemicamente injustas ou a falência dos sujeitos em desafiá-las. A entrevista da Camila está, assim, em sintonia com as falas dos outros entrevistados que também buscaram relatar seus esforços de "traduzir" a "cultura do CONARE" para o solicitante sem parecer afrontá-la diretamente, apontando possíveis injustiças nas suas práticas diárias já cristalizadas ${ }^{38}$.

Seja nos grupos de elegibilidade, seja nas entrevistas preparatórias na Cáritas-Rio, os atores buscam explicar e "traduzir" aos solicitantes de refúgio a "cultura do CONARE", a fim de que as narrativas possam ser não somente encaixadas, mas desenvolvidas à luz das expectativas subjetivas dos membros do Comitê. Conforme me contou uma funcionária da instituição, "na preparação, já sabendo a expectativa que o oficial de elegibilidade tem, e de que maneira ele entende que uma história é melhor narrada, ou melhor contada, a gente trabalha com o solicitante essa forma específica de narrar a história”. A partir da posição da Cáritas como membro representante da sociedade civil no CONARE e que, tendo em vista sua proximidade com outros membros do Comitê, possui certa expertise acerca de como os atores percebem o processo, haveria uma busca por gerenciar expectativas e, como me disse um funcionário da instituição, "antecipar isso para a pessoa para que ela, nas suas respostas, tenha a visão desse jogo".

O trabalho desenvolvido com os solicitantes de refúgio é entendido, assim, como traduzir aos sujeitos o que os oficiais de elegibilidade querem saber das suas

\footnotetext{
${ }^{38}$ Cabe lembrar aqui a estrutura multiministerial do CONARE, da qual participa com poder de voto a sociedade civil. Nesse sentido, embora muitas falas dos entrevistados, especialmente daqueles inseridos em instituições que representam a sociedade civil, apontem críticas às análises de credibilidade do oficial do CONARE, é preciso ter em mente a participação da sociedade civil na própria estrutura. Permanece, em grande medida, uma postura de manutenção da dinâmica de poder no Comitê, assegurando o papel da sociedade civil através da instituição representante desde a fundação do órgão. Em termos da dimensão epistêmica, produz-se a aceitação das estruturas que podem configurar injustiças testemunhais e hermenêuticas que afetam a vida dos sujeitos em busca de refúgio.
} 
histórias. Beatriz, da Cáritas-Rio, me contou em entrevista sobre um episódio particular a respeito deste tema, no qual um solicitante de refúgio perguntou ao oficial que o entrevistava: "o que você quer que eu responda? Não estou entendendo aonde você quer chegar com as perguntas. O que você quer da minha história?". Para a funcionária da Cáritas-Rio, então, “o que a gente tenta fazer com eles [solicitantes de refúgio] é identificar o que o oficial quer da história e, então, trabalhar isso com eles". Apesar de relatar alguns casos concretos que indicariam que os oficiais demandam das "histórias de refúgio" elementos como riqueza de detalhes e cronologia, por exemplo, quando perguntei se ela poderia me dizer o que exatamente o oficial de elegibilidade quer saber das histórias, Beatriz afirmou que "depende muito de cada oficial" - uma resposta que acompanhou outros entrevistados a respeito das dinâmicas de cada entrevista de elegibilidade e que chama a atenção para uma possível prática discricionária também neste espaço de troca testemunhal.

Nas falas dos entrevistados a respeito das expectativas existentes sobressai o esforço em busca de uma "tradução" das imagens subjetivas acerca das "histórias de refúgio" e a melhor maneira de narrá-las. A tentativa de munir o solicitante com informações que possam ajudá-lo a compreender melhor o processo e aquilo que os diferentes atores esperam dele é atravessada pela existência de um gap fundamental em relação às posições ocupadas pelos sujeitos. A forma como os distintos atores parecem lidar com o privilégio epistêmico que se faz presente nas práticas do refúgio por elegibilidade pode contribuir para a produção de uma injustiça testemunhal ao deixar de lado um questionamento das expectativas existentes em prol de um gerenciamento delas. O solicitante é orientado, assim, a adaptar seu testemunho ao modelo reconhecido, observando questões de cronologia, detalhamento das narrativas e consistência interna, por exemplo, mas permanece sendo visto como o sujeito que "não é capaz de dar grandes explicações" tendo em vista sua própria condição de desvantagem nesse sistema - que, ao final, parece ser apenas mantida ${ }^{39}$.

\footnotetext{
${ }^{39}$ Embora eu tenha procurado ressaltar aqui a manutenção de uma posição de privilégio epistêmico que pode, em última instância, contribuir para a produção de injustiças, também é preciso ter em mente a ambivalência existente na busca por gerenciar expectativas. Considerando a possibilidade do indeferimento dos casos, o trabalho de muitos atores mencionados tem se desenvolvido à luz da percepção de uma necessidade de adaptar as narrativas às expectativas de modo a contribuir para o deferimento das solicitações de refúgio. Assim, embora eu perceba a manutenção de uma dinâmica estrutural de desigualdade, também considero o esforço dos atores em aproximar os solicitantes das
} 


\section{3}

\section{Vencer Incoerências e Convencer o Outro}

A busca por gerenciar expectativas no refúgio por elegibilidade também é acompanhada por aquilo que os entrevistados chamaram de "o trabalho de vencer incoerências" e convencer o "outro" (geralmente entendido como o oficial de elegibilidade do CONARE). No âmbito da Cáritas-Rio e da Defensoria Pública, as falas de alguns atores apontaram para um quadro de existência de incoerências nos testemunhos dos solicitantes de refúgio, da necessidade de superar tais incoerências e orientar os sujeitos em suas narrativas a fim de que possam ser convincentes. A busca pelo convencimento é entendida aqui não somente como algo que deve ser empreendido pelo solicitante, mas também como aquilo que deve ser articulado entre os próprios membros do CONARE, especialmente as instituições que representam a sociedade civil e se organizam com a Defensoria Pública para a defesa de casos.

Busco, assim, contribuir para compreensões acerca de um ponto de partida sobre a suposta existência de incoerências nos testemunhos dos solicitantes de refúgio e, portanto, a necessidade de superá-las. O convencimento como um trabalho a ser empreendido não só pelo solicitante, mas também pelos membros do CONARE, traz uma diferenciação significativa: ao mesmo tempo em que o solicitante deve reconhecer o caráter subjetivo das avaliações de credibilidade, fornecendo imagens sobre as histórias de perseguição com capacidade para afetar o outro, os membros do Comitê devem empreender uma tarefa racional/burocrática de convencimento diante dos outros atores deste processo de elegibilidade.

Partindo da perspectiva exposta por alguns entrevistados acerca da incoerência como algo comum nas narrativas dos solicitantes de refúgio, procuro refletir sobre a importância de abrir-se à possibilidade de erros de julgamento, tendo em vista não só a existência de barreiras lingüísticas e traumáticas, mas também o necessário fracasso de todo projeto autonarrativo, nos termos propostos por Butler

\footnotetext{
imagens que são esperadas deles, de modo a aumentar as chances de compreensão dos sujeitos em relação às práticas da elegibilidade. Há, nesse sentido, uma ambivalência que parece refletir a própria dificuldade de atuação em um sistema no qual uma instituição representante da sociedade civil busca, ao mesmo tempo, trabalhar com solicitantes e refugiados de modo a ajudá-los a diminuir sua posição de desvantagem e, ainda, compor a própria estrutura decisória que determina a concessão do status.
} 
(2017). Mais do que isso, a falência em desenvolver tal postura poderia produzir uma injustiça epistêmica, considerando a inabilidade em questionar crenças e julgamentos, bem como em monitorar nossas práticas em trocas testemunhais (Kwong, 2015). Questiono, ainda, a possibilidade de uma deferência à autoridade que corrobora e legitima julgamentos de credibilidade, sem desconsiderar o papel que as reações emocionais desempenham no estabelecimento de vínculos de confiança.

Cecília, da Cáritas-Rio, me contou que, no decorrer das entrevistas na instituição, podia observar que "sempre tinha incoerências" no testemunho dos solicitantes de refúgio. Apesar disso, quando perguntada sobre a menção ao suposto relato incoerente na entrevista, dando espaço para que o sujeito pudesse esclarecer alguma contradição, a voluntária afirmou que apenas "explicava que precisava melhorar [a narrativa], que tinha ficado em dúvida". Durante a sua fala, torna-se claro que parte do seu próprio trabalho era "separar pontos fracos da entrevista, que podiam ser problemáticos" a fim de que fosse possível, posteriormente, produzir um documento (nos moldes do parecer oficial de elegibilidade) para orientar a defesa do caso pelo advogado da instituição. Questionada sobre como ela sabia o que poderia constituir um "ponto fraco" dos testemunhos, Cecília traz à tona a idéia de que haveria "pontas soltas" no projeto autonarrativo dos sujeitos.

Normalmente eram informações que ele tinha dado, mas que ele não tinha confirmado, não tinha como confirmar, coisas que estavam meio soltas, os advogados mesmo já indicavam para gente o que tinha de problemas nessas entrevistas e que seria bom reforçar no parecer, ou na entrevista da pessoa. Por dificuldade de língua ou por trauma, sei lá o que era, ela não conseguia explicar quem era esse grupo, porque ela tinha fugido, então a gente ia nesses pontos né, tentando fundamentar (Cecília, Cáritas-Rio, grifo meu).

Ainda que reconheça a possibilidade da influência de traumas e barreiras lingüísticas na troca testemunhal, Cecília ressalta que a presença de incoerências seria algo comum nas narrativas dos solicitantes de refúgio. Uma parte significativa do trabalho dela na instituição passa a ser, assim, identificar as incoerências nos testemunhos dos sujeitos a fim de que pudessem ser melhoradas ou resolvidas ${ }^{40}$. O

\footnotetext{
${ }^{40}$ Como tenho buscado indicar no decorrer de toda a tese, parte significativa do esforço de trabalhar as narrativas dos solicitantes de refúgio está ligada à percepção dos atores da sociedade civil acerca das dificuldades inerentes ao processo de elegibilidade. Há, assim, uma busca por auxiliar tais sujeitos a fim de que possam navegar melhor as complexidades das práticas de entrevista. Ainda que seja possível compreender esta postura como uma tentativa de aumentar as chances de sucesso das solicitações, não podemos desconsiderar a manutenção das estruturas desiguais que sustentam o
} 
reconhecimento de obstáculos à inteligibilidade das narrativas, como a questão lingüística ou a possibilidade de traumas, não parece ser suficiente para evitar que Cecília estabeleça seu julgamento de que ao menos parte do relato do solicitante de refúgio é incoerente. Os chamados "limites de nossos esquemas de inteligibilidade" (Butler, 2017, p.34), que podem se apresentar na troca testemunhal com o solicitante de refúgio, não são questionados como algo que pode ter implicações significativas na continuidade do diálogo e na exigência do processo de reconhecimento - neste caso, reconhecimento da história de perseguição que o solicitante traria consigo. O que Cecília parece desconsiderar em sua fala é aquilo que Butler denomina de parcialidade de todo relato que o sujeito oferece sobre si mesmo e que, necessariamente, apresenta determinados pontos cegos. Se todo relato autonarrativo é parcial, há sempre na narrativa algo que escaparia à compreensão, uma vez que "há algo em mim e de mim do qual não posso dar um relato" (Butler, 2017, p.55).

Reconhecer a parcialidade dos testemunhos seria, assim, abrir mão da expectativa da coerência completa naquilo que é narrado pelo solicitante de refúgio, abrindo espaço para apreender os limites epistêmicos que, segundo Butler, estariam presentes em qualquer relato autonarrativo e no processo de reconhecimento do outro. Em sua crítica à perspectiva de Fricker (2007), Kwong (2015) nos traz a importância epistêmica de manter a "mente aberta" em relação à possibilidade de erros que cometemos na formação de nossas crenças. Necessitamos, segundo tal perspectiva, desenvolver uma pré-disposição para descobrir quais tipos de erros cognitivos estamos acostumados a cometer e monitorar os sinais de que estamos em uma situação em que é mais provável que tais erros sejam cometidos. Nesse sentido, ao refletir sobre o espaço de troca testemunhal com o solicitante de refúgio, torna-se relevante abrir-se à possibilidade de erros de julgamento quanto à incoerência dos testemunhos dos sujeitos, trazendo à tona não somente a existência de barreiras lingüísticas e traumáticas, mas também o necessário fracasso de todo projeto autonarrativo. Não desenvolver tal postura epistêmica aberta, nos termos propostos por Kwong, poderia produzir uma injustiça epistêmica, uma vez que, segundo o autor, estaríamos abrindo mão de levar a sério o desafio de questionar

processo e a participação dos atores da sociedade civil no julgamento da credibilidade dos solicitantes no âmbito do CONARE. 
nossas crenças e julgamentos, monitorando nossas práticas epistêmicas de maneira atenta.

A imagem de que uma solicitação de refúgio seria intrinsecamente "fraca" por ser atravessada pelas supostas incoerências nas narrativas dos sujeitos, exposta brevemente no capítulo anterior, foi articulada por Vítor, da DPU de Brasília, enfatizando o processo de escolha dos casos que seriam defendidos por ele nos espaços coletivos de discussão. O que ele traz, porém, não é a perspectiva de que todos os solicitantes apresentam testemunhos em alguma medida incoerentes, mas sim de que, apenas nos casos em que uma incoerência se faz presente nas narrativas, não seria possível defender perante o CONARE que o sujeito é, de fato, um refugiado.

É, a gente examina todos né, e vê quais são os mais fortes, por exemplo, tem alguns critérios que a gente vem utilizando, alguns casos que tem problema de credibilidade interna, a gente tenta não brigar tanto entendeu. Aquela discussão se o relato do cara é coerente ou não, porque o ponto de partida já está com problema, e aí a chance de ganhar isso no CONARE é muito pequena, quando eles identificam contradição interna no discurso da pessoa e aí chegam à conclusão de que não há uma credibilidade interna (Vítor, DPU de Brasília, grifo meu).

Assim como nos trechos anteriores, parte da entrevista relatada acima traz a relevância do que os atores julgam ser coerente ou não nas narrativas dos solicitantes de refúgio. Embora Vítor reconheça a importância do trabalho de convencimento, conforme veremos a seguir, não há questionamento sobre a credibilidade interna, uma vez que o Comitê tenha determinado a existência de problemas intrínsecos ao testemunho do solicitante. Dessa maneira, a credibilidade interna, "um dos pontos mais polêmicos" do processo, conforme me contou Tatiana, oficial de elegibilidade do CONARE, não entraria em disputa a partir das estratégias de atuação do funcionário da DPU. A "parte que dá mais debate, mais dúvida", ainda segundo a oficial, não é, assim, uma questão a ser discutida na prática da defensoria no processo de elegibilidade.

Ainda que a fala do entrevistado levante a questão estratégica de que a ausência de questionamentos sobre credibilidade interna se deva à dificuldade de vitória nos espaços de decisão e debate, é preciso refletir sobre a existência daquilo que Origgi (2012) chama de deferência à autoridade. Ao buscar expandir a análise da injustiça testemunhal indicando outros mecanismos que interferem nas análises de credibilidade, a autora afirma que o processo de internalizar as normas sociais no modo como aceitamos argumentos enunciados por autoridades pode impactar as 
práticas de atribuir ou negar credibilidade a determinados sujeitos e afirmações. Nesse sentido, seria relevante questionar se parte da recusa da defensoria pública em engajar um debate sobre os fundamentos da análise de credibilidade interna realizada pelos oficiais do Comitê não constitui uma forma de deferência à autoridade dos funcionários do Ministério da Justiça e Segurança Pública, que preside o CONARE e produz os pareceres de elegibilidade. Conforme vimos no trecho da entrevista, Vítor não indica apenas que o Comitê identificou contradição interna nas narrativas, mas corrobora e legitima, sem questionamentos ou críticas, essa avaliação ao afirmar que "o ponto de partida já está com problema".

A partir das identificações de supostas incoerências nos testemunhos dos solicitantes de refúgio, parte do trabalho dos funcionários e voluntários da CáritasRio passa a ser a busca por superar tais incoerências. Para isso, os atores da instituição teriam que "orientar o relato, no sentido de que ele seja convincente, de que aquela pessoa específica sofre ou pode sofrer perseguição individualizada", conforme me contou Maria, da Cáritas-Rio. Neste contexto, seria preciso, então, orientar os solicitantes de refúgio tendo em mente que "existe essa dificuldade de enquadrar o relato no que a gente entendia que ia ser compreendido como caso de refúgio". A entrevistada prossegue sua fala a respeito do esforço que é feito para tornar racional a análise dos testemunhos e identificações de incoerências.

Tem sempre um esforço para racionalizar, para vencer as incoerências. Porque eu acho que o processo de decisão passa por isso: quando existe alguma inconsistência, o processo de decisão passa pela avaliação de credibilidade interna, que é justamente isso, se o que o solicitante está falando não vai entrar em contradição com o que ele mesmo fala, se o relato não entra em contradição. E depois credibilidade externa, se aquelas informações estão batendo com as informações do país de origem. Então sim, o trabalho passa por um processo de tentar vencer essas pontas soltas [...] (Maria, Cáritas-Rio, grifo meu).

Ao longo de sua fala, porém, e sem nenhuma interrupção da minha parte, a voluntária parece dar-se conta de que as incoerências fazem parte dos sujeitos:

Maria: [...] o que não deixa de ser problemático, porque a gente tem ponta solta, isso todo mundo tem, ninguém não entra em contradição consigo mesmo, não quer dizer que a história não é verdadeira.

Eu: A incoerência poderia ser, por exemplo, um lapso de memória, você acha?

Maria: sim, pode ser um lapso de memória. Pode estar relacionado também com algum trauma ou simplesmente falha da mente humana. 
Quando questionada a respeito do modo como seria o trabalho de "vencer incoerências", Maria me conta que buscava apontar as supostas "pontas soltas" nos testemunhos durante as entrevistas com os solicitantes de refúgio, ainda que, segunda ela, as incoerências não fossem vencidas em todos os casos. Na prática, isso significava sair dos espaços de troca testemunhal com o solicitante sem ter esclarecido partes da narrativa que o funcionário/voluntário acreditava apresentar problemas de credibilidade interna. A partir disso, torna-se mais complexo o trabalho de convencimento de outros membros do CONARE, uma vez que o próprio funcionário da Cáritas-Rio poderia não estar "convencido" acerca da credibilidade interna do testemunho do solicitante de refúgio. Entra em cena, assim, o processo de avaliar casos fortes e fracos a fim de escolher aqueles que seriam defendidos pela instituição nos espaços coletivos de debate e decisão, conforme abordei no capítulo anterior.

Em entrevista, Fernando, da Cáritas-Rio, deixa clara a perspectiva de que uma de suas tarefas é, precisamente, auxiliar o solicitante de refúgio no processo de elegibilidade a fim de que ele possa empreender o trabalho de convencer o oficial do CONARE sobre sua "história de refúgio". O projeto de convencimento passaria, segundo o entrevistado, pelo fornecimento de detalhes, imagens e sensações acerca da perseguição, para que fosse possível deslocar o testemunho da esfera burocrática, aproximando-o do âmbito emotivo. Conforme ele me contou, o solicitante precisa compreender a importância de passar ao entrevistador, através do seu testemunho, as imagens do que aconteceu, a fim de que o oficial de elegibilidade possa ter uma imaginação sobre o ocorrido. Nesse sentido, "dar imagem significa dizer para ele: olha, era manhã, eu estava em tal lugar, era uma rua assim. Ajudar essa pessoa, porque o convencimento não é racional". Para o funcionário, então, o trabalho de convencimento passaria por "possibilitar imagens que a pessoa [oficial de elegibilidade] consiga imaginar: ah, isso é razoável".

O que o funcionário da Cáritas-Rio nos traz como relevante no processo subjetivo do convencimento do outro é, precisamente, o papel das reações emocionais àquilo que é narrado pelo solicitante de refúgio. Conforme nos diz Origgi (2012), algumas vezes podemos confiar em alguém não pelo que nos é dito, mas sim porque temos uma reação emocional que nos levaria a estabelecer um vínculo de confiança. Assim, ao tratar sobre outros elementos (para além de preconceitos e estereótipos) que podem influenciar as análises de credibilidade e 
causar uma injustiça epistêmica, Origgi afirma que o efeito da primeira impressão é algo que comumente é utilizado para avaliar credibilidade, sendo também algo profundamente baseado em reações emocionais. Ao me contar que "o convencimento não é racional” e, portanto, o solicitante de refúgio precisa "possibilitar imagens" sobre sua narrativa de perseguição, o funcionário da CáritasRio expõe o caráter subjetivo das análises de credibilidade realizadas pelos oficiais do CONARE. Se o solicitante é bem-sucedido ou não neste processo emotivo de convencimento passa a ser fundamental para seu processo de solicitação de refúgio, o que levanta os perigos de ter no seio do processo de determinação do status de refugiado uma análise subjetiva de credibilidade que pode produzir cenários de injustiça epistêmica.

Outros entrevistados, como Vítor, da DPU de Brasília, trouxeram a perspectiva do convencimento como um trabalho a ser operado pela própria instituição no processo de elegibilidade, em parceria com outras organizações representantes da sociedade civil. Já tendo ocorrido a fase da entrevista de elegibilidade, o trabalho de convencimento recai sobre alguns membros do CONARE que devem atuar de maneira articulada para questionar possíveis obstáculos levantados por outros membros do Comitê em relação ao deferimento das solicitações. Aqui, novamente, o próprio funcionário da DPU já deve ter sido "convencido" sobre a força de uma determinada solicitação de refúgio, a fim de que empreenda o esforço de defendê-la perante outros membros, conforme vimos no capítulo anterior. Vítor faz referência ao trabalho de convencimento ao relatar um caso específico debatido no GEP e na plenária, trazendo à tona, ainda, a articulação entre a DPU e outros membros, como Cáritas-Rio e ACNUR. Ainda que em sua fala Vítor traga o Comitê como órgão independente desses outros atores, é comum ouvir de algumas instituições as referências ao CONARE como sinônimo do órgão que o preside, o Ministério da Justiça e Segurança Pública.

Nós tivemos um caso de casamento inter-religioso na Índia, o cidadão era hindu e a moça era Muçulmana né, no norte da Índia. Os relatórios internacionais não falavam especificamente de homem Hindu e mulher muçulmana, então o CONARE no início começou a criar muito caso a respeito disso. Os relatórios diziam que, sim, que os casamentos inter-religiosos na Índia eram um problema, inclusive no norte do país de onde vinha esse solicitante de refúgio que estava sendo perseguido por conta do casamento inter-religioso, mas não havia nada especifico falando de homem e mulher muçulmana. Então nós entendemos que seja assim um preciosismo extremo do CONARE exigir um relatório, já que havia uma informação de que casamento inter-religioso em geral seria problemático. Que justiça seja feita, nós fizemos um trabalho de convencimento, houve entrevistas complementares pela Cáritas-Rio e 
pelo ACNUR, memoriais foram distribuídos, nós enfim fizemos um trabalho que durou acho que 3 ou 4 sessões de entrada em pauta de julgamento e retirada para obter mais informações, que no fim até o próprio CONARE se convenceu né, dessa nossa argumentação e felizmente foi deferido com unanimidade esse caso. Mas houve um pouco esse embate quanto à questão dos relatórios e o que seriam essas informações de origem e qual a profundidade exigida dela (Vítor, DPU de Brasília, grifo meu).

Apesar de também se referir ao trabalho de convencimento no processo de elegibilidade, podemos considerar uma discrepância significativa deste trecho acima em relação à fala anterior do funcionário da Cáritas-Rio sobre a tarefa do solicitante de refúgio de convencer o oficial. No relato de Vítor, o trabalho de convencimento é visto como um procedimento técnico e racional, com a distribuição de memoriais e a retirada de pauta do caso para obtenção de novas informações até que, por fim, a presidência do Comitê teria sido convencida da argumentação racional que alguns membros apresentaram. Por outro lado, pela fala de Fernando, o trabalho de convencimento que o solicitante de refúgio deve empreender no espaço da troca testemunhal com o oficial de elegibilidade é uma tarefa subjetiva, que deve apelar para a imaginação do entrevistador. Conforme me contou o funcionário da Cáritas-Rio, seria preciso ajudar o oficial a imaginar.

As práticas da elegibilidade passam, assim, por uma série de gestão das emoções, em que o solicitante de refúgio precisa encarar a demanda de vencer as supostas incoerências em seus testemunhos e convencer os membros do Comitê de que é um sujeito crível. Embora reconheça a importância dos preconceitos e estereótipos neste conjunto de práticas, o que irei analisar na parte final deste capítulo, ganha força aqui a perspectiva de que há outros mecanismos que podem enviesar as análises de credibilidade realizadas. Conforme nos diz Origgi (2012), a quantidade de confiança que depositamos em nossos interlocutores depende de uma série de fatores, tornando necessária a atenção às nossas práticas epistêmicas diárias. Tendo em mente a importância do processo de (des) confiar, em especial no refúgio por elegibilidade, irei me deter a seguir na busca subjetiva pela construção de um ambiente de confiança e na postura de desconfiança do Comitê em relação aos solicitantes.

\section{4 \\ O papel da (des)confiança}


De maneira geral, o conhecimento pode ser entendido a partir de um nexo íntimo no que diz respeito à palavra do outro, o que evidenciaria sua dependência em relação aos testemunhos (Hardwig, 1991; Lipton, 1998). Seria preciso julgar, assim, em que ou em quem confiamos. No caso específico do refúgio, a localização da análise de credibilidade no centro dos processos de determinação da condição refugiada faz com que ganhe ainda mais relevância o papel da confiança no testemunho do solicitante. Não só a narrativa, como também o próprio sujeito, precisariam soar críveis para o interlocutor, a fim de produzir uma disposição geral para acreditar (Audi, 2003). Apesar do reconhecimento da importância do ato de confiar no solicitante de refúgio e em seu testemunho, os entrevistados durante a pesquisa ressaltaram em suas falas a necessidade de produção de um ambiente de confiança do solicitante em relação ao funcionário das instituições. Quando trouxeram à tona outra direção das relações de confiança, o que emergiu foi a existência de uma postura de desconfiança do oficial de elegibilidade do CONARE diante dos solicitantes de refúgio.

A contribuição que busco fazer aqui parte, assim, da discussão sobre a necessidade de produção de um ambiente de confiança para que o solicitante de refúgio possa narrar sua história. Segundo esta perspectiva, o vínculo de confiança - do solicitante no entrevistador - seria um instrumento fundamental para o processo de elegibilidade. Já no que diz respeito à confiança do oficial no solicitante, é possível perceber a existência de uma postura de desconfiança que impacta a troca testemunhal negativamente. Haveria, assim, não apenas uma prática voltada para a identificação de supostas contradições nas narrativas dos sujeitos, como também uma postura de confrontação direta, segundo o relato de um refugiado. É preciso analisar, assim, o que esse cenário significa em termos de uma análise de credibilidade no processo e a possibilidade de produção de uma injustiça epistêmica.

$\mathrm{O}$ argumento desenvolvido nesta seção gira em torno da perspectiva de que os julgamentos de credibilidade desempenham papel central no processo de determinar qual testemunho é ou não crível. Nesse sentido, a ênfase sobre a confiança do solicitante no oficial, de acordo com as falas de vários entrevistados, parece não reconhecer que as dinâmicas envoltas em avaliações de credibilidade, através de déficits e excessos, reforçam a importância de estabelecer em quem confiamos nas nossas trocas testemunhais e por quais motivos. Torna-se 
fundamental refletir, assim, sobre como as práticas da elegibilidade abarcam percepções e julgamentos sobre a credibilidade dos solicitantes, que são avaliados e valorados a partir da confiança que pode ser estabelecida na veracidade do seu testemunho. Cabe ter em mente, então, a existência de mecanismos, como reações emotivas, que fazem com que confiemos ou desconfiemos dos nossos interlocutores.

Grande parte dos entrevistados mencionou em suas falas a importância de "criar um vínculo de confiança", conforme afirmou Júlio, da Cáritas-Rio, a fim de que os solicitantes de refúgio pudessem narrar suas histórias e temores de perseguição nas entrevistas de elegibilidade e também nos espaços de troca testemunhal em instituições representantes da sociedade civil. Maria, da mesma instituição, me contou como procura fazer com que o solicitante confie no entrevistador ao explicar o sigilo referente às informações compartilhadas:

$\mathrm{Na}$ maioria das vezes eu tenho a sensação de que a gente consegue construir esse ambiente de confiança, mas às vezes a pessoa se sente... você vê uma defensiva, e sempre que eu consigo identificar isso eu chamo a atenção para a questão da confiabilidade: que nada do que é dito dentro da Cáritas, ou mesmo para o Conare, vai ser divulgado para o país de origem, para o governo e mesmo para qualquer outro agente perseguidor. Eu sinto que na maior parte das vezes a gente consegue estabelecer uma boa relação (Maria, Cáritas-Rio, grifo meu).

O estabelecimento de um vínculo de confiança foi ressaltado pelos entrevistados como algo necessário da parte do solicitante de refúgio em relação ao entrevistador ou oficial de elegibilidade do Comitê, permitindo a produção de um testemunho crucial para o processo. A produção da confiança não é vista, assim, como algo que envolve também a necessidade do oficial ou membro do CONARE em confiar no solicitante, mas como uma ferramenta que facilitaria a narrativa dos sujeitos sobre sua vida no país de origem. Esta perspectiva foi, em alguma medida, exposta por Júlio, da Cáritas-Rio, que compara em sua fala o papel do oficial de elegibilidade do Comitê com aquele de outros profissionais, como um médico ou advogado, trazendo à tona a capacidade de inspirar a confiança do outro como um dom, algo nato, que os sujeitos possuem ou não:

Ontem eu estava falando aqui com um médico que já não está mais trabalhando, que é um amigo que a gente conversava muito, ele fez essa comparação do padre, o advogado, o médico, e outras pessoas também né, tem outras profissões, que a confiança que a pessoa transmite para quem está conversando, ela transmite essa confiança a pessoa se sente segura para falar, isso é dom, isso é qualidade, isso é nato de cada um, eu quero ser, mas você não tem um, é difícil de dizer (Júlio, CáritasRio, grifo meu). 
Embora seja fundamental pensar a necessidade de um ambiente seguro para que o solicitante de refúgio possa compartilhar informações sobre sua vida e seus temores de perseguição, é questionável imaginar esta produção a partir de uma perspectiva instrumental que enfatiza apenas a possibilidade de uma maior disposição do sujeito em narrar sua história. A idéia de que um ambiente de confiança é necessário para que o solicitante se sinta seguro para falar menospreza o caráter central que julgamentos de credibilidade exercem na determinação de qual testemunho o oficial pode tomar como crível. As dinâmicas envoltas em avaliações de credibilidade, seja através de excessos ou déficits, apontam para a importância de determinar em quem confiamos nas trocas testemunhais (e por quais motivos). Conforme nos diz Origgi (2012), preocupada em ampliar a abordagem de Fricker (2007) sobre os fatores que interferem em uma economia de credibilidade produzindo injustiça epistêmica, é necessário refletir sobre como a confiança é alocada de maneiras diversas a depender, por exemplo, de julgamentos e percepções a respeito dos interlocutores. Nesse sentido, mais relevante do que produzir um ambiente no qual o solicitante de refúgio possa confiar em seu interlocutor, é refletir sobre os fatores que interferem na produção de confiança do oficial no solicitante, uma vez que este quadro pode contribuir para déficits de credibilidade que impactam o processo de determinação da condição refugiada.

A busca por produzir a confiança do solicitante de refúgio nos funcionários/voluntários das instituições é trazida à tona como parte do trabalho destes atores no seio do processo de elegibilidade, permitindo a construção de uma "estrutura para a pessoa confiar", conforme me contou Vanessa, do CEPRI. Segundo ela, é fundamental para o processo que o solicitante esteja confortável em narrar sua vida, facilitando a "relação de confiança" com os atores das instituições. Embora Vanessa tenha levantado a idéia de uma "relação" em sua fala, o restante do seu relato ainda expõe a confiança como algo que apenas o solicitante deve apresentar diante daquele que o interpela. Quando questionada sobre a abertura que os solicitantes teriam para narrar suas histórias, Vanessa me contou a respeito do esforço realizado para que o solicitante de refúgio confie no funcionário da instituição e como a resposta a tal esforço é atravessada, por exemplo, pela nacionalidade dos sujeitos: 
Alguns casos são difíceis né, alguns casos a gente... a gente, por exemplo, tem um convênio lá com a própria PUC, do setor de psicologia, então assim a gente já encaminhou caso para lá. Então vai sendo montada a estrutura para a pessoa confiar né, às vezes realmente confiam muito e contam intimidade da vida, pede conselho amoroso (risos) então assim, a relação é boa, claro que dependendo da nacionalidade tem uma questão de ser mais rápido, mais devagar [...] (Vanessa, CEPRI, grifo meu).

Em sintonia com a fala do Júlio, da Cáritas-Rio, o que a funcionária do CEPRI expõe é a necessidade de "montar a estrutura para a pessoa confiar", o que significa criar um ambiente de confiança do solicitante nos funcionários da instituição. Mais do que isso, sua fala traz à tona como a existência de estereótipos relacionados à nacionalidade dos sujeitos pode ser usada como fator explicativo para o ritmo da criação desse ato de confiar no funcionário do CEPRI. Embora reconheça a relevância de um ambiente no qual o solicitante se sinta seguro para narrar sua história e, assim, permita o trabalho daqueles que irão buscar fundamentar sua solicitação de refúgio com base em critérios da lei, também emerge como preocupação a idéia de uma estrutura de confiança sendo montada a partir de uma direção única do ato de confiar. Porém, as práticas da elegibilidade envolvem, necessariamente, as percepções e julgamentos sobre a credibilidade dos solicitantes de refúgio, que são avaliados e valorados a partir da confiança que pode ser estabelecida na veracidade do seu testemunho. Não é possível menosprezar, como afirma Origgi (2012), a importância de uma economia da credibilidade baseada numa série de atitudes, valores, emoções e inferências cognitivas que formam a base de uma confiança epistêmica ${ }^{41}$.

A importância do ato de confiar, a ser adotado pelo solicitante de refúgio, atravessa outros campos institucionais para além da proteção legal e elegibilidade dos sujeitos no processo de determinação de status, sendo apontado como fundamental também na área da assistência social, por exemplo. Questionada sobre o impacto do seu trabalho na vida dos solicitantes e refugiados, Sofia, da CáritasRio, me contou como o próprio trabalho de assistência é pensado não como uma finalidade, mas como um meio de fazer com que o solicitante possa "confiar de novo" em alguém:

\footnotetext{
${ }^{41} \mathrm{~A}$ autora define a confiança epistêmica como uma atitude que envolve não apenas uma confiança mínima no interlocutor, necessária para que o próprio ato de comunicação possa ocorrer, mas também uma confiança vigilante, que consistiria em uma série de mecanismos cognitivos, disposições emocionais, normas herdadas e sinais de reputação, que são utilizados no processo de filtrar as informações recebidas.
} 
É uma vida que não morre de fome porque a gente de alguma forma interveio, e a gente entende isso não como o fim do nosso trabalho, mas isso é o meio. É um meio inclusive de reconquistar a confiança de pessoas que muitas vezes não conseguem mais confiar em ninguém. Isso para gente é muito importante, muito caro. Às vezes a gente recebe refugiado aqui que foi para uma entrevista de emprego, já estava há cinco anos no Brasil, e foi para uma entrevista de emprego, ele ficou com uma dúvida e veio perguntar: você acha que isso está certo? Você acha que eu devo confiar nisso? Ele falou para eu ir viajar, você acha que eu devo ir? Então assim, o nível de confiança que se estabelece perdura, então eu acho que de alguma forma a gente consegue construir esse vínculo com ele. Isso pra gente é muito caro, e é muito difícil conquistar a confiança de alguém que você não conhece, é muito difícil. E quando esse alguém é alguém que viveu o que o refugiado viveu é ainda mais difícil, confiar de novo é muito difícil, mas pra gente é muito importante [...] (Sofia, Cáritas-Rio, grifo meu).

Outro funcionário da Cáritas-Rio, Caio, relatou em entrevista como o trabalho dos funcionários/voluntários é voltado para fazer com que os sujeitos atendidos "tenham uma confiança" neles, ainda que isso não signifique torná-los presos à instituição. Da fala do entrevistado surge o papel central da confiança do solicitante e refugiado no funcionário da Cáritas-Rio, possibilitando que haja uma compreensão dos sujeitos em relação aos ditames da instituição:

O nosso intuito não é fazer com que eles se prendam com a gente, pelo contrário, quando a gente percebe que a pessoa está muito presa a gente procura saber o porquê, a gente vai impulsionar essa pessoa a retomar a vida dela e não ficar presa à Cáritas. Eu acho que esse diálogo favorece, faz com que gere neles a confiança em nós, entendeu, e a confiança faz com que eles se abram à ajuda, faz com que eles entendam que não é simples, não é fácil, não é de qualquer maneira, não é no momento que eles querem, do jeito que eles querem, na hora que eles querem. Então eu acho que é fundamental essa relação com eles, assim, como eu disse no início, respeitando, compreendendo, mas principalmente acolhendo, trazendo para perto e ajudando. Eu acho que é uma marca forte da Cáritas (Caio, Cáritas-Rio, grifo meu).

Já no que diz respeito ao estabelecimento de vínculos de confiança do oficial de elegibilidade do Comitê no solicitante de refúgio, nas poucas vezes em que tal direção do ato de confiar surgiu nas entrevistas, a perspectiva relatada apontou que haveria uma postura de desconfiança desses oficiais em relação aos solicitantes. Apesar da afirmação da Tatiana, oficial de elegibilidade, de que havia a "tentativa de criar uma relação de confiança desde o momento inicial da entrevista", fazendo com que os solicitantes "se sentissem ao menos confortáveis", Guelor, refugiado da RDC, me contou que a dinâmica imposta na entrevista levantava a aura de suspeita em relação aos entrevistados. Tendo não apenas passado, ele mesmo, pelo espaço da troca testemunhal do processo, como também acompanhado inúmeros 
solicitantes em suas entrevistas, no papel de intérprete, o refugiado me contou que "a entrevistadora quer pegar o refugiado, pegar na mentira [...] fazer a pessoa se contradizer". Questionado sobre o que isso significava em termos da dinâmica da entrevista, o refugiado afirmou que a entrevistadora "volta na mesma pergunta de uma forma diferente, tenta desestabilizar o refugiado".

Guelor: Você já sente que a pessoa está duvidando do que você está falando e aí isso deixa a pessoa mais preocupada e ela começa a errar mais.

Eu: Você sente que a expressão corporal da pessoa é de duvidar do que você diz?

Guelor: De dúvida, sim, ou até chegar o momento que começam a dizer: para com isso, eu não estou acreditando. Me fala sua história verdadeira.

Eu: E você acha que isso varia muito dependendo de quem é o entrevistador ou essa dinâmica seria institucionalizada, algo da própria instituição?

Guelor: Já virou uma instituição mesmo, todos eles, entendeu, estavam fazendo isso.

Eu: De confrontar o solicitante na hora, de falar que ele está mentindo e dizer me fala a verdade?

Guelor: Isso.

Eu: E isso deixa o solicitante nervoso na hora?

Guelor: Meu deus, deixa! Porque o documento é muito importante pra gente, muito importante, define sua vida, o resto da sua vida aqui no Brasil [...]

O relato do refugiado está em sintonia com a fala do coordenador do CONARE sobre a dinâmica de "repetir a mesma pergunta várias vezes, mas em momentos distintos" a fim de, segundo ele, "verificar se a pessoa cai em contradição ou não". Embora não tenha mencionado uma postura de confrontação direta nas entrevistas no que diz respeito ao caráter de verdade dos testemunhos dos solicitantes, o coordenador trouxe a perspectiva de que há uma dinâmica geral préestabelecida para a entrevista de elegibilidade, ainda que possa variar dependendo das informações levantadas pelos entrevistados.

[...] Além disso, quando a pessoa conta a história a gente vai pedindo confirmação dos fatos. Uma das funcionalidades dessa técnica é de repetir a mesma pergunta várias vezes, mas em momentos distintos, é verificar se a pessoa cai em contradição ou não, se ela fica confusa ao responder, ou se ela tem certeza, fala com propriedade, enfim. Mas a entrevista ela é muito... é, vamos dizer assim, tem um padrão, mas ela é muito variável porque depende da vida da pessoa também, mas existe uma moldura que a gente segue, vamos dizer assim. Tem uma moldura que a pintura é feita de acordo com o relato do solicitante, e a gente tem que saber o que fazer e como fazer, naquela condução né, dentro daqueles limites ali da entrevista. Então já tem, vamos dizer tem um procedimento pré-estabelecido, onde a gente se 
apresenta, pergunta se a pessoa está confortável, explica a nossa função, a gente fala que a gente é o MJ, é o responsável por fazer a entrevista né, tomar nota de tudo o que a pessoa falar, explica o que é o refúgio, e aí parte para a investigação do que era, como era a vida do solicitante no país de origem (Carlos, Coordenador do CONARE, grifo meu).

Ainda que não tenha se referido em sua fala a uma confrontação direta que partiria de uma desconfiança naquilo que o solicitante de refúgio diz, o coordenador do Comitê traz à tona a existência de práticas voltadas para identificar contradições nas narrativas dos sujeitos. Entendida como uma estratégia, a repetição da mesma pergunta várias vezes e em momentos distintos busca prover as razões para a (des) confiança testemunhal, justificando a atribuição ou não de déficits de credibilidade. Nesse sentido, e usando os termos do coordenador do CONARE, se o solicitante não fica confuso ao responder, se fala com certeza e propriedade, então haveria uma base suficiente para confiar na consistência interna da narrativa, isto é, acreditar no solicitante como fonte das informações sobre um determinado quadro de perseguição. Tal estratégia, assim como a confrontação direta sobre o suposto caráter de mentira nos testemunhos, revela não a existência ou ausência de veracidade, mas como o que está em questão nas trocas testemunhais com o solicitante é a produção de estratégias para justificar os atos de confiar ou desconfiar dos sujeitos. Em outras palavras, torna-se evidente que a credibilidade do solicitante não é algo que depende apenas da capacidade dos sujeitos em responder às estratégias empregadas por seus interlocutores, mas também da alocação de confiança do oficial de elegibilidade sobre aqueles que solicitam o refúgio.

As entrevistas que preparariam os solicitantes para a entrevista oficial do processo, e que têm lugar na Cáritas-Rio conforme já falado no decorrer do capítulo, também emergem como importantes para esclarecer pontos que poderiam "causar algum tipo de desconfiança do CONARE”, segundo Marina, da Cáritas-Rio. Uma parte significativa do trabalho seria, então, ler o formulário de solicitação de refúgio, pesquisar sobre o país de origem e sobre fatos específicos apontados no relato e, por fim, destacar os pontos principais nas narrativas que poderiam ser vistos com desconfiança por parte do oficial de elegibilidade do Comitê. Questionada sobre o que poderia causar tal desconfiança, Marina afirmou apenas que o importante era a "consistência interna da história", o que fazia com que ela fosse obrigada a estudar documentos sobre análise de credibilidade que seriam 
usados pelos oficiais para avaliar a credibilidade interna e externa das narrativas dos solicitantes de refúgio.

É importante ter em mente que a confiança não emerge como algo passivo: uma série de estratégias inferenciais é normalmente utilizada para avaliar os informantes e o conteúdo dos seus testemunhos (Origgi, 2012). Desconfiar de alguém e atribuir um déficit de credibilidade com base em uma postura de desconfiança não está relacionado apenas à existência de preconceitos e estereótipos que influenciam as trocas testemunhais. Conforme afirma Origgi, outras estratégias para avaliar credibilidade, para além da mobilização de preconceitos, podem acabar produzindo uma injustiça epistêmica, tornando necessária a atenção a outros fatores implicados no ato de confiar. Nesse sentido, emerge como central em uma economia da credibilidade a manutenção de uma postura atenta à operação de mecanismos que fazem com que confiemos ou desconfiemos de nossos interlocutores. Origgi aponta como um desses mecanismos as chamadas reações emotivas, as quais podem fazer com que nossa confiança seja atribuída (ou não) sem motivo aparente, mas apenas porque algo produz em nós uma emoção profunda. Tal perspectiva não contradiz a visão de Fricker (2017) sobre o papel da confiança na atribuição de credibilidade, uma vez que para esta autora a postura de confiança também é vista como emergindo de um sentimento.

Julgar a credibilidade de alguém envolveria, assim, apresentar ou não um sentimento de confiança em relação à sinceridade daquilo que é narrado, o que envolve necessariamente uma emoção ou percepção do outro enquanto um sujeito confiável e um tipo de engajamento baseado na empatia (Fricker, 2017). Tanto Fricker quanto Origgi (2012) trazem a avaliação de credibilidade para o âmbito do subjetivo, das emoções e dos sentimentos, afastando uma dimensão puramente racional do julgamento daquilo ou de quem pode ser considerado crível. Embora todo este capítulo tenha sido construído de forma a analisar aspectos subjetivos que desafiam a aura de racionalidade dos processos de refúgio, a próxima seção irá abordar um aspecto significativo nas falas dos entrevistados durante a pesquisa: a idéia de que existiria um feeling, um sentimento sobre as "histórias de refúgio", utilizado para avaliar a credibilidade dos casos.

\section{5 \\ O feeling sobre as histórias de refúgio}


No capítulo anterior vimos como as constantes referências à força ou fraqueza de um "caso" compõem a gramática da análise de credibilidade no universo institucional do refúgio no Brasil. Porém, naquele momento, procurei me ater à dimensão burocrática do processo de elegibilidade a partir das falas dos entrevistados a respeito da objetividade das avaliações de credibilidade interna e externa dos testemunhos dos solicitantes. Neste capítulo, e com a ênfase sobre a dimensão subjetiva do processo, proponho refletir sobre a imagem compartilhada por vários entrevistados acerca da existência de um sentimento, um feeling, em relação às "histórias de refúgio". A perspectiva sobre a credibilidade do solicitante e de seu testemunho como algo avaliado a partir de um sentimento sobre a autenticidade da solicitação de refúgio nos ajuda a pensar o processo em termos mais complexos do que a narrativa da racionalidade burocrática dá conta de explicar. Ainda que tenha buscado desenvolver uma análise crítica desta narrativa no capítulo anterior, apenas aqui me detenho sobre um discurso explicitamente voltado à percepção subjetiva sobre os sujeitos e suas histórias.

As contribuições desenvolvidas neste capítulo estão relacionadas às reflexões a respeito do papel central que a percepção subjetiva sobre os casos e os solicitantes de refúgio desempenha nos julgamentos de credibilidade e no processo decisório como um todo. É possível trazer à tona, a partir deste cenário, o caráter subjetivo do refúgio por elegibilidade, com a permanência de dúvidas e questionamentos mesmo após a tomada de decisão sobre o deferimento ou indeferimento das solicitações. Vemos emergir, a partir das falas dos entrevistados, uma busca por compreender o sentimento dos solicitantes e ser afetado pelos seus testemunhos a fim de que seja possível decidir. A percepção subjetiva dos atores envolvidos neste universo também emerge das falas sobre os critérios utilizados na análise de credibilidade com menções a uma espécie de feeling sobre a autenticidade dos sujeitos e suas solicitações de refúgio.

Busco argumentar, então, sobre a importância que o sentimento sobre o solicitante de refúgio e sua história desempenha nas avaliações de credibilidade. A partir disso, é possível compreender como o impacto de julgamentos em uma economia da credibilidade não é determinado apenas pela operação de estereótipos e preconceitos, mas também por fatores como as reações emocionais (Origgi, 2012). Esta ênfase sobre o papel dos sentimentos e emoções nas práticas de 
determinação da condição refugiada permite a expansão da abordagem da injustiça testemunhal de Fricker (2007), trazendo com Origgi (2012) a importância de outros mecanismos que predispõem ou influenciam as avaliações de credibilidade.

Embora muitos entrevistados tenham feito referências a percepções subjetivas sobre a credibilidade das solicitações de refúgio, a fala que expressou de maneira direta a importância do sentimento nas avaliações dos casos foi a do Júlio, da Cáritas-Rio. Cabe ressaltar aqui a importância de levar em consideração a perspectiva do entrevistado que, estando ausente das discussões supostamente técnicas (GEP), desempenha um importante papel no julgamento das solicitações no plenário do CONARE. Sendo um dos poucos entrevistados com conhecimento direto para me relatar a dinâmica das reuniões oficiais em que os casos são decididos, o funcionário da instituição trouxe uma imagem crucial sobre o processo. Questionado a respeito do funcionamento de tais reuniões, ele me falou sobre o papel central que o sentimento pode desempenhar nos espaços coletivos e decisórios:

Na discussão às vezes a gente pede para refazer a entrevista, para aprofundar mais, pede opinião do ACNUR, ou pede relatório do Itamaraty, sobre determinadas regiões, pesquisa sobre acontecimentos dos países de origem, informação da Anistia... e tem muitos casos, assim, às vezes é o dia inteiro, só ler o caso, ouvir entrevista, perguntar de novo, às vezes chama o assistente de proteção para falar, dizer qual foi o sentimento (Júlio, Cáritas-Rio, grifo meu).

O entrevistado relata, assim, que em algumas ocasiões o oficial de elegibilidade que entrevistou o solicitante de refúgio é convidado a participar da reunião do plenário do Comitê a fim de que possa compartilhar o sentimento que teria sido desenvolvido a partir da troca testemunhal. A questão não seria, assim, relatar as informações obtidas através das perguntas ou mesmo da entrevista oficial, que constam nos documentos acessados pelos membros, mas sim trazer as percepções subjetivas que foram criadas a partir do encontro com os solicitantes.

Eu: Mas vocês chegam a chamar o oficial de elegibilidade para a plenária?

Júlio: Sim

Eu: O oficial que entrevistou naquele caso específico?

Júlio: Sim, a gente pede ajuda da pessoa para explicar

Eu: Explicar o que? Alguma coisa da entrevista?

Júlio: Porque tem muitos porquês que ficam... por que você perguntou isso... Tem tudo escrito também. Mas e o sentimento? Então o sentimento. Por isso que estou 
dizendo para você: quem faz a entrevista é a pessoa que tem as qualidades para fazer né... sensibilidade, verdadeiro e falso com o tempo o entrevistador começa a aprender.

A perspectiva de que o sentimento sobre o solicitante e sua história é crucial para julgamentos de credibilidade está em sintonia com a análise realizada por Origgi (2012) a respeito das estratégias utilizadas para julgar os interlocutores e as informações que trazem para o espaço da troca testemunhal. Conforme nos diz a autora, não é somente a existência de preconceitos e estereótipos que podem impactar as avaliações de credibilidade, mas também uma série de outros fatores como, por exemplo, as reações emocionais. Assim, grande parte da confiança que atribuímos ao outro está relacionada a reações emocionais que não podemos controlar e que emergem do encontro com nossos informantes. O processo de formação de nossos julgamentos de confiança é atravessado pela dinâmica do contato direto com o outro e, nesse sentido, o efeito da primeira impressão é algo normalmente utilizado para analisar a credibilidade de um sujeito, tendo como base reações emocionais profundas (Origgi, 2012).

Ao relatar a dificuldade que sente na tomada de decisões, Júlio, da CáritasRio, traz à tona o caráter subjetivo que fornece as bases para a decisão sobre a concessão ou não do status de refugiado ao solicitante. Questionado sobre a subjetividade das decisões, que pode estar refletida em casos similares com pareceres diferentes, o entrevistado afirma que é normal que ocorra esta discrepância e acrescenta: “uma mesma história, dois finais". Quando perguntei se esta diferença de pareceres ocorria também para familiares que apresentavam suas solicitações de refúgio, Júlio enfatizou como é difícil para ele participar desse processo e saber se está votando certo:

Júlio: Eu confesso para você que não é nada confortável participar do CONARE. Às vezes eu saio de lá, puxa vida! Às vezes eu até quero que o caso seja, vejo que não foi, e fico na dúvida, será que é isso mesmo? Será que eu estou fazendo a coisa errada? Será que eu votei certo? Tanto certo quando conceder, quanto certo quando não conceder.

Eu: Você vota também pela não concessão [do status de refugiado]?

Júlio: Sim. E isso às vezes é duro, viu?! Alguns casos aqui do Rio eu quis um dia estar junto com o candidato a refúgio, porque não era entrevista, só para ver quem era a pessoa e conversar um pouco... qualquer coisa para sentir, não é fácil não. 
A imagem do caráter subjetivo do processo de elegibilidade fica ainda mais evidente a partir da fala que destaquei acima, que aponta as dificuldades para a concessão do refúgio e a permanência das dúvidas e questionamentos mesmo após a decisão já ter sido tomada. Ao me contar que buscava "ver quem era a pessoa e conversar um pouco... qualquer coisa para sentir” , Júlio traz à tona o fato de que, conforme afirma Origgi (2012), uma economia da credibilidade é profundamente marcada por diferentes estratégias cognitivas e preconceitos que ajudam a distribuir a confiança de maneiras desiguais entre os participantes de uma troca testemunhal. A partir disso, torna-se crucial ter em mente a possibilidade de produção de uma injustiça epistêmica que impede a participação dos solicitantes de refúgio como sujeitos do conhecimento, especialmente se os membros do Comitê estão tomando como base suas emoções para atribuir déficits de credibilidade aos testemunhos. Dessa maneira, seria necessário suspeitar dos próprios julgamentos e emoções para que fosse possível abrir espaço para o monitoramente de erros no processo de avaliar credibilidade (Kwong, 2015).

Conforme foi possível ver anteriormente, Júlio, da Cáritas-Rio, expressa as dificuldades que encontra para avaliar e decidir se uma solicitação de refúgio deve ou não ser deferida, afirmando que mesmo após sua decisão ter sido tomada as dúvidas permanecem. Mais do que isso, emerge como central da fala do Júlio a busca, sempre que possível, por um contato com o solicitante de refúgio para que possa "sentir" o que emana da troca com o outro. Nesse sentido, se vimos no capítulo anterior o esforço por racionalizar as decisões e a menção ao debate entre os "técnicos do refúgio", vemos emergir aqui o papel central que alguns membros do Comitê atribuem ao sentimento. Assim, seria necessário buscar "qualquer coisa para sentir" não somente entre os membros que avaliam as solicitações, mas também entre os oficiais de elegibilidade que entrevistam os solicitantes de refúgio e que precisariam também avaliar o sentimento dos entrevistados nos espaços de troca testemunhal.

Eu vejo lá os entrevistadores hoje do CONARE, são pessoas dedicadas que se esforçam, que vieram de outras áreas, mas que não foram... para ser oficial de proteção eu diria que é preciso ter o dom, ter uma vocação para isso, ter um sentimento humanitário, ao mesmo tempo que tem que ter a capacidade de penetrar, de ouvir e de reinterpretar o sentimento de outra pessoa, o sentimento é algo muito próprio e pessoal, e cada um de nós tem...(Júlio, Cáritas-Rio, grifo meu).

Apesar de reconhecer em sua fala que "o sentimento é algo muito próprio e pessoal", o entrevistado ressalta a capacidade de "reinterpretar o sentimento de 
outra pessoa" como uma das capacidades que um oficial de elegibilidade deve possuir. Não bastaria apenas fazer uso dos próprios sentimentos para avaliar a credibilidade dos sujeitos, mas seria também importante reinterpretar as emoções relativas aos solicitantes de refúgio. O que significaria uma reinterpretação dos sentimentos do outro não fica claro no decorrer da entrevista, apenas permanecendo as ênfases do discurso sobre a importância do sentimento para atribuir ou não déficits de credibilidade. As práticas do processo de determinação da condição refugiada aparecem, assim, cada vez mais atravessadas pela capacidade de ser afetado pelo testemunho do solicitante e distribuir credibilidade a partir disso. Conforme me contou Fernando, da Cáritas-Rio, "tem uma afetação o tempo inteiro. Isso é muito forte". Questionado sobre se ele se percebia dessa maneira, isto é, afetado pelo outro, o funcionário afirmou que era algo recíproco, mas que o importante era "investir nessa ferramenta de trabalho". De acordo com ele, o solicitante deveria compreender que "a comunicação tem que ser afetiva", uma vez que "o oficial vai captar sinais afetivos dele, assim, se ele está chorando, se está triste, isso tudo".

Outros entrevistados fizeram menções em suas falas ao papel que a percepção desempenha nas avaliações sobre os casos, o que faz com que haja uma espécie de feeling sobre a autenticidade de uma solicitação de refúgio. Quando questionada a respeito dos critérios utilizados para determinar a credibilidade de um solicitante e sua história, Maria, da Cáritas-Rio, afirmou que "tem um pouco de feeling, mas tem também a questão dos precedentes. A gente sabe mais ou menos quais são os tipos de casos que são com mais frequiência deferidos e os que são com mais freqüência indeferidos". O sentimento em relação aos casos vai ganhando, então, um espaço crucial nos processos desenvolvidos nesta instituição representante da sociedade civil no CONARE. Maria me contou como sua percepção sobre as "histórias de refúgio" orientava, por exemplo, a necessidade de desenvolver novas e aprofundadas pesquisas para ajudar o advogado a defender a solicitação nos espaços coletivos do Comitê. Assim, segundo ela, "quando a gente já sentia que o caso ia passar por dificuldades no processo de decisão, a gente fazia uma pesquisa para corroborar". A entrevistada prossegue sua fala me explicando que "a pesquisa que a gente realiza no setor de proteção é usada no GEP para defender casos indicados para indeferimento. Quando é um caso mais difícil e que a gente sente que vale a pena ser defendido, é criado um memorial de defesa". 
Ainda que eu tenha buscado repetir meus questionamentos aos entrevistados sobre como eles desenvolviam seus critérios de avaliação dos casos que "valem a pena ser defendidos", as respostas normalmente oscilaram entre "ter precedentes" e "sentir" que é um caso autêntico de refúgio. Ao questionar Beatriz, da CáritasRio, sobre a dinâmica das entrevistas no setor de proteção legal e elegibilidade da instituição, ela me contou que "muitas histórias eram muitas vezes histórias que a gente tinha percepção de que seria difícil uma avaliação como uma necessidade de proteção real, então histórias que muitas vezes pareciam histórias de migração econômica”. $\mathrm{Na}$ busca por tentar me responder como esta percepção era desenvolvida e o que parecia ser uma história de migração econômica, Beatriz relata que, em alguns casos, os solicitantes afirmavam não ter sofrido perseguição ou estar apenas em busca de "melhor oportunidade de vida". Logo a seguir, porém, e sem ser interrompida, ela explica que "também é difícil que o solicitante tenha a percepção do que é válido de ser compartilhado ou não". Ainda segundo ela, teria impacto sobre o processo o conhecimento dos sujeitos sobre o que é importante compartilhar e a forma como as entrevistas são conduzidas.

É possível compreender, a partir das falas dos entrevistados sobre o papel das emoções e percepções no processo de elegibilidade, a existência de diferentes mecanismos nas práticas de distribuição de confiança e, portanto, da avaliação de credibilidade $^{42}$. A ênfase sobre o papel das reações emocionais na concessão do status de refugiado permite não somente a expansão da abordagem da injustiça testemunhal de Fricker (2007), trazendo com Origgi (2012) a importância de outros mecanismos que predispõem ou influenciam as avaliações de credibilidade, como também abre espaço para reflexões sobre o caráter intrinsecamente subjetivo do refúgio por elegibilidade. Tal perspectiva nos afasta de uma concepção do processo como sendo atravessado pela argumentação racional e especialista dos "técnicos do refúgio" e nos aproxima de uma imagem da (des)ordem das percepções subjetivas sobre os solicitantes e seus testemunhos. Não reconhecer este aspecto fundamental do processo pode fazer com que um quadro de injustiça testemunhal se manifeste,

\footnotetext{
${ }^{42}$ Não é possível ignorar, ainda, a existência de uma postura de ansiedade nos entrevistados em relação ao seu papel no processo. Em outras palavras, não pretendo diminuir, em meio às críticas, a angústia pessoal transmitida por vários dos entrevistados no que diz respeito tanto à condução das entrevistas e produção dos pareceres sobre os casos quanto ao processo decisório em si. Tendo em vista a subjetividade que atravessa os processos, a angústia pessoal dos entrevistados sobre sua participação nas complexas dinâmicas decisórias emerge com força significativa em algumas das falas.
} 
uma vez que "preconceitos e suposições erradas seguem seus próprios cursos" (Kwong, 2015, p.345).

\section{6}

\section{Concepções sobre a condição refugiada}

A pesquisa que deu início a esta tese propôs a relevância de uma investigação acerca dos significados produzidos em torno da condição refugiada, levando em consideração as questões de justiça e poder nas práticas diárias da elegibilidade. A partir do questionamento da categoria do refugiado, torna-se possível repensar os diferentes regimes de visibilidade e produção de conhecimento que são construídos como espaços possíveis de habitação para os sujeitos em situação de refúgio. Com isso em mente, perguntei a todos os entrevistados sobre suas concepções do que seria a condição refugiada, trazendo para a pesquisa alguns significados principais atribuídos à figura do refugiado. A miríade de significados, que procurei organizar aqui a partir de determinadas entrevistas, vai desde um debate sobre a concepção legalista, passando por imagens comuns do refugiado enquanto sujeito sem escolha devido ao caráter forçado do deslocamento, chegando à visão da resiliência desses sujeitos.

É preciso analisar um ambiente institucional do refúgio no Brasil que produz uma série de concepções distintas sobre a figura do refugiado e torna difícil a inteligibilidade acerca da condição do refúgio, uma vez que há tentativas de racionalização de uma experiência essencialmente social e política vivida por terceiros. A partir de posições epistemicamente privilegiadas, como procurei criticar no decorrer de toda a análise das entrevistas, há a tentativa de estabelecimento e determinação de quem é o refugiado, ainda que os sujeitos que vivam a experiência desta condição encontrem obstáculos a sua participação ativa na produção de significados sociais a partir da sua própria situação de refúgio. Procuro, por fim, trazer algumas das críticas e questionamentos levantados pelos solicitantes e refugiados acerca da existência de preconceitos e estereótipos que mediam suas relações com diversos brasileiros, bem como suas concepções acerca da condição refugiada.

Alguns funcionários/voluntários entrevistados, quando questionados a respeito de sua concepção sobre o que consistiria a figura do refugiado, afirmaram 
que esta não seria uma questão que envolve suas imagens pessoais sobre os sujeitos, mas sobre "aquilo que está na lei". Conforme me contou o coordenador do CONARE, "a definição do refúgio não é a minha posição pessoal ou institucional, é a posição da lei, da lei brasileira". O coordenador prosseguiu, então, recitando para mim a lei 9.474 que estabelece os critérios para a determinação da condição refugiada. Maria, da Cáritas-Rio, também buscou partir da definição legal de refugiado para explicar o que considera ser esta condição, embora também trouxesse em sua fala questionamentos sobre como interpretar os próprios critérios que constam na legislação.

A minha definição de refúgio, que eu sempre passo para os refugiados é a definição oficial que o governo brasileiro vai compreender como um caso de refúgio. Em termos grosseiros, quando o solicitante consegue provar ou é convincente no sentido de que ele deixou o país de origem ou de residência habitual porque aconteceu, ou ele acha que pode acontecer caso ele retorne para esse país, alguma situação de perseguição que ameace a vida ou a integridade física, emocional, psicológica dessa pessoa e que essa perseguição ela ocorra por motivos de raça, etnia, nacionalidade, opinião política, grupo social, religião, ou porque se entende que nesse país existe uma situação de grave e generalizada violação dos direitos humanos, que é uma compreensão bem amarradinha. Eu não sei se sempre o solicitante vai entender o que são essas categorias, por isso é importante acompanhar a solicitação de refúgio, o preenchimento do formulário, pra ver se essas categorias estão sendo mobilizadas de alguma maneira, até porque grupo social, o que é grupo social? (Maria, CáritasRio, grifo meu).

No decorrer de sua fala veio à tona o que Maria considera um processo subjetivo, arbitrário e violento de definição do refugiado, o que faz com que seja possível problematizar o aspecto legal de determinação da condição refugiada.

Com o tempo, e até estudando o tema, começou a bater o aspecto ético, de quem sou eu para definir se essa pessoa, dentro de tudo que ela viveu até hoje, é ou não refugiado, se é um caso forte ou um caso fraco. Eu reproduzo essa linguagem no diaa-dia, porque em termos práticos, vai ser percebido como forte, vai ser percebido como um caso fraco, mas é uma violência, eu vejo como uma violência, e é extremamente arbitrário e subjetivo. E eu sinto que principalmente se a pessoa está fazendo o trabalho há pouco tempo ela tem mais dificuldade de fazer a diferença entre caso forte e caso fraco, porque você está na frente de uma pessoa que teve que sair do país dela, por alguma situação muito grave no entendimento dela, ela deve estar emocionalmente ainda muito próxima disso, e você está ouvindo isso tudo, e depois quando você vai consultar alguém mais experiente ou algum advogado e diz, olha esse caso não é forte, tem sempre uma divergência... (Maria, Cáritas-Rio, grifo meu).

Embora ressalte a importância do aspecto legal para caracterizar a figura do refugiado, Maria também salienta a dificuldade para definir alguns dos critérios legais para a concessão do refúgio, como o critério de pertencimento a um grupo social. Ao prosseguir com sua fala, ela traz à tona o caráter subjetivo e violento de 
tentar encaixar as experiências dos sujeitos nos critérios legais da definição de refugiado, afirmando que há sempre divergências a respeito da inclusão ou não de determinada solicitação no quadro do refúgio. Tais considerações lançam luz sobre a dificuldade em tornar uma experiência social, vivenciada pelos sujeitos, inteligível em termos dos critérios legais usados para definir quem podemos reconhecer como refugiado.

Aqui é possível ter, dentro de um quadro de injustiça epistêmica, uma manifestação da dimensão hermenêutica de injustiça, considerando a complexidade envolvida em "traduzir" as experiências para a linguagem burocrática e racional da legislação. Conforme nos diz Fricker (2007, p.154), a dimensão hermenêutica traria uma "injustiça de ter uma área significativa da experiência social obscurecida em termos de conhecimento coletivo devido a uma marginalização hermenêutica". Nesse sentido, poderia haver problemas na inteligibilidade das experiências sociais de certos grupos, dificultando, por exemplo, o reconhecimento de um sujeito como refugiado, uma vez que os próprios critérios legais levantam dúvidas sobre a interpretação das experiências - como disse Maria: "até porque grupo social, o que é grupo social?".

Já Vanessa, do CEPRI, trouxe para a entrevista um aspecto paradoxal de seu trabalho, me contando que, formalmente, ela "tende a seguir os critérios da lei" e, ao mesmo tempo, em sua visão pessoal, acredita que "quem não se sente protegido ou acolhido, e não tem perspectivas decentes no próprio país, já é um refugiado. Não precisa ter os motivos de perseguição exatamente". Ainda segundo Vanessa, que atua em defesa de solicitantes de refúgio, refugiados e imigrantes, não haveria uma distinção clara entre uma migração por motivos econômicos e uma migração em busca de refúgio. Assim, "se a pessoa está num lugar e não tem condições para se desenvolver, isso já é uma forma de perseguição. O Estado não te dá o amparo que você precisa. Mas quando a gente está acompanhando, a gente tende a enquadrar as pessoas nos critérios definidos em lei”.

Eu: É fácil esse enquadramento nos critérios da lei?

Vanessa: Não, não é fácil, mas você acaba aprendendo mais ou menos o que as pessoas, o que o CONARE leva em consideração, o que ele considera perseguição, o que ele tende a aceitar um pouco mais. Por exemplo, mulheres é um grupo social, seria. Tem que ser um grupo de mulheres dentro de um grupo de mulher, então assim, a gente sabe que eles aceitam, por exemplo, mulheres de determinada nacionalidade apesar de ser um grupo enorme, já é um grupo social, já é o suficiente sabe. Mas assim, a gente também cria recortes que a gente acha que podem ser explorados. Mas 
não é uma coisa que a gente tenha catalogado, eu acho que vai muito do caso e como a gente pensa. Eu acho que grande parte da equipe pensa da mesma forma que eu, de que se a pessoa não tem condições mínimas no país dela, ela acaba sendo refugiada, a gente sempre tenta ver o que o Estado não está fornecendo. A gente ali vai criar uma perseguição, não criar, mas identificar o que pode ser aproveitado do ponto de vista do CONARE. Mas não tem como te dizer que a gente tem um catálogo, que isso é muito preciso, é muito do próprio caso né, da análise do caso e nem sempre isso funciona, até porque eles [CONARE] não pensam da mesma forma que a gente.

Laís, funcionária da Missão Paz-SP, ao mesmo tempo em que enfatiza o caráter forçado da fuga que permitiria diferenciar o refugiado do imigrante, também traz uma crítica à busca por adotar uma posição legalista em detrimento do benefício da dúvida em favor do solicitante de refúgio. Apesar da postura crítica, sua fala também traz uma imagem importante e problemática em termos das práticas epistêmicas que procuramos discutir aqui:

Pra mim, essa pessoa [refugiado] foi forçada a se deslocar, ela teve um deslocamento forçado e isso independe da situação migratória dela no momento: irregular, solicitante, refugiado. Não é fácil separar o refugiado do migrante econômico, principalmente pra quem está vivendo isso. A gente que estuda e tem mais conhecimento consegue avaliar pelos critérios quem pertence a tal grupo, pra quem vive essa situação - de miséria e se sente obrigado a sair - como explicar pra ela que esse deslocamento não é forçado? Pra ela foi, ela não queria sair, mas precisa do emprego. Pra essa pessoa o deslocamento não foi voluntário, foi forçado. Mas pra legislação foi voluntário, não forçado. Acho que são linhas bem tênues. O que demanda bastante sensibilidade da parte de quem faz essa análise de elegibilidade e que nem sempre acontece. Se a pessoa é legalista ao extremo, e ela só aceita como refúgio aquilo que está previsto em lei, se o caso for um caso claro, que não gere dúvida, e ela opta por não reconhecer, pode estar colocando em risco a vida de uma pessoa porque foi totalmente legalista. Contraria o principio básico do refúgio que é garantir a vida e segurança da pessoa: se você está na dúvida deveria reconhecer e não assumir o risco da vida da pessoa. Infelizmente não é sempre assim que acontece (Laís, Missão Paz-SP, grifo meu).

Embora reconheça as dificuldades de separação entre a figura do migrante econômico e do refugiado, Laís afirma uma diferença entre a capacidade do funcionário que avalia os casos e dos solicitantes em definir quem está ou não em uma situação de refúgio. Ainda que traga em sua fala a possibilidade de dúvidas no que diz respeito ao enquadramento das experiências nos critérios legais do estatuto do refugiado, a entrevistada expressa a existência de uma posição epistêmica privilegiada. Conforme nos diz Medina (2011), a existência de uma autoridade epistêmica, à qual é atribuído um excesso de credibilidade, permite que determinados sujeitos sejam considerados capazes de avaliar questões como sentimentos e plausibilidade das narrativas dos interlocutores. Seria, assim, a 
existência de um privilégio epistêmico dos atores responsáveis por determinar a condição refugiada o que permite que Laís afirme que "a gente que estuda e tem mais conhecimento consegue avaliar pelos critérios quem pertence a tal grupo". Dessa maneira, a existência de dúvidas a respeito do enquadramento legal não deslegitimaria o papel dos atores que, em função de uma expertise adquirida, pode legislar como "técnico do refúgio" ao estabelecer quem é ou não um refugiado.

Outros entrevistados ressaltaram em suas definições sobre a condição refugiada o caráter forçado da fuga que diferenciaria o refúgio da migração econômica. Nesse sentido, o que caracterizaria a figura do refugiado seria esta dimensão específica de ausência de escolhas a respeito do deslocamento do país de origem ou residência habitual. Conforme me contou Cecília, da Cáritas-Rio:

Pra mim, eu acho que refugiado é quando uma pessoa se vê forçada a sair do seu lugar porque ela corre risco de vida, ou porque ela acha que vai acontecer uma coisa ruim com a família dela, porque ela sente um risco iminente, um medo ou alguma coisa nesse sentido, porque eu acho que ninguém quer sair da sua casa. Eu leio muitos pareceres de pessoas que vinham do Congo, fugiam para Angola, ou para outro país que tinha saída para o mar, e entravam mulheres com crianças pelo lastro do navio, sem saber para onde iam, e descobriam quando chegavam em São Paulo. Elas nem sabiam que vinham para o Brasil. Eu não sei precisar quanto tempo era de viagem, era uma viagem longa, e com medo eles desciam no primeiro porto que atracava, e normalmente era em São Paulo, aí eles descobriam que estavam no Brasil, e muitos não gostavam (Cecília, da Cáritas-Rio).

Lorena, da Cáritas-Rio, também reforça a imagem do caráter forçado da fuga que torna a condição refugiada tão específica em meio ao regime de mobilidade. A ausência de escolhas a respeito do deslocamento é atravessada pelas práticas de violação de direitos que recaem sobre estes sujeitos que solicitam refúgio e fazem com que sua situação seja marcada por um quadro de sofrimento.

Para mim, é uma pessoa que sai do seu país, que está numa situação de muita violação de direitos, e sai muitas vezes para não morrer ou para sair daquela situação de sofrimento, de violência. Então, assim, são pessoas que chegam porque precisam, porque não tiveram escolha, porque tem direito de viver, porque tem direito de recomeçar, porque os países não podem ter fronteiras, porque não tem fronteira para mercadoria, para ideias, para dinheiro, mas para pessoas tem. Para pessoas pobres tem, não pode ter fronteiras para pessoas pobres, todo mundo tem direito de circular, como tudo circula, né?! (Lorena, Cáritas-Rio).

A imagem da fuga em busca do refúgio como um deslocamento forçado, sem que o sujeito pudesse manifestar seu poder de escolha, atravessou a fala de entrevistados de diferentes instituições e em posições diversas no trabalho com refugiados no Brasil. Os entrevistados ressaltaram, assim, uma obrigatoriedade de saída do país de origem em função de uma série de violações de direitos e práticas 
de violência que recaem sobre aqueles que são forçados a se deslocar. Conforme me contou Tatiana, oficial de elegibilidade do CONARE, o refugiado é "a pessoa obrigada a sair do país dela, não é uma migração voluntária, mas tem uma condição de vulnerabilidade porque tem o fundado temor de perseguição. O pressuposto é sempre de que o deslocamento é forçado". Não encontramos apenas a perspectiva de que o deslocamento forçado é atravessado pela perda do poder de escolha, mas também a visão de que a condição refugiada é marcada por uma série de perdas. Conforme me contou Sofia, da Cáritas-Rio, “o refugiado não é só a pessoa que saiu do seu país de origem, mas é uma pessoa que vive uma história de perdas várias, que culmina na perda do seu próprio país, da sua casa, da sua família, mas antes disso, em geral, tem outras muitas perdas".

Outros entrevistados, especialmente aqueles que estão inseridos na CáritasRio, buscaram ressaltar em suas falas a imagem do refugiado não a partir da ausência de escolhas no momento da fuga, mas da resiliência que estes sujeitos apresentam, com afirmações de que o refugiado "não é um pobre-coitado, mas sim uma pessoa corajosa", segundo Joana, da Cáritas-Rio. De acordo com esta perspectiva, o caráter forçado não é o que caracteriza a condição refugiada, uma vez que "querendo ou não, essa pessoa tem agência, tem algum tipo de agência, de decidir para onde vai ou não, de pegar talvez a única oportunidade de saída que surgiu". A imagem da resiliência ocupa, assim, papel central em algumas concepções que os entrevistados trouxeram em suas falas a respeito da condição refugiada, deixando de lado qualquer menção ao caráter forçado da fuga para enfatizar as práticas dos sujeitos nos países de acolhida.

A despeito de tudo que ele [refugiado] possa ter passado, tem uma questão de resiliência que eu acho impressionante né, de continuar. E aí eu mudo um pouco daquela pessoa que tem uma necessidade específica na minha frente para uma pessoa que é um vencedor, que tem essa capacidade muito grande de se reinventar e de sobreviver. Nesse trabalho aqui que eu faço na proteção eu tento ver mais os refugiados como essa pessoa que ela tem essa resiliência muito grande, passa pelas dificuldades, se reinventa e está batalhando e tal, e o que eu puder fazer de mínimo para ajudar é o mínimo. É muito pouco perto daquilo que ele consegue por si só (José, Cáritas-SP).

Apesar da ênfase sobre o caráter da resiliência, quando questionado a respeito da concepção de refugiado para fins de concessão do status, ou seja, no processo de elegibilidade, a fala do José passou a estar centrada na imagem do fundado temor de perseguição. A imagem do refugiado é deslocada, assim, da idéia de resiliência para a perspectiva do medo, que seria a especificidade que permite 
diferenciar o refugiado do migrante econômico. Nesse sentido, e ainda segundo o entrevistado, "qual é a especificidade do refugiado, ok, todos eles passam pela questão da resiliência, tanto o imigrante quanto o refugiado, mas qual a especificidade do refugiado? O fundado temor e o que ele traz para determinado indivíduo".

A pluralidade de significados atribuídos à categoria do refugiado, que atravessa as falas de diferentes entrevistados, pode limitar ou dificultar a capacidade de uma troca testemunhal inteligível sobre a experiência vivenciada por refugiados. Seja através das concepções legalistas, da dimensão forçada do deslocamento ou da ênfase sobre as idéias de resiliência e medo, há uma pluralidade de conceitos que pré-determinam a figura ideal do refugiado. Mesmo diante da possibilidade de diálogo e troca, com todos os limites existentes na interação entre sujeitos, a escuta poderia permanecer diminuta e carregada pelos excessos da racionalização burocrática de uma experiência essencialmente social e política. É preciso refletir, assim, sobre a existência de um processo de elegibilidade que abre espaço para posições epistemicamente privilegiadas daqueles que seriam capazes de estabelecer e determinar quem é o refugiado e o que constitui esta condição, sem trazer para as discussões as perspectivas dos próprios sujeitos que vivem a experiência do refúgio. Este quadro permite, ainda, a produção de uma lacuna hermenêutica, uma vez que os solicitantes e refugiados acabam sendo impedidos de participar ativamente na produção de significados sociais sobre a própria condição refugiada.

As imagens sobre a condição refugiada que os entrevistados apresentaram em suas falas não se movem apenas entre a dimensão legalista, o caráter forçado do deslocamento ou a resiliência e o medo, mas também atravessam concepções sobre o refúgio enquanto condição reivindicada politicamente. Camila, da Cáritas-Rio, me contou como, na sua concepção, "o processo [de elegibilidade] não diz nada. Se a pessoa se auto-determina enquanto refugiado, ela torna isso uma categoria política. Essa pessoa pra mim é refugiada". Ao mesmo tempo, Camila afirma que "o refugiado é uma categoria social e jurídica criada para instituir uma lógica de controle migratório e, em alguns casos, uma condição de regularização". A perspectiva exposta pela entrevistada traz à tona, assim, um espaço de disputa entre um processo de controle e regularização migratória, por um lado, e uma apropriação política da condição refugiada pelos próprios sujeitos, por outro lado. Esta imagem é compartilhada por outro funcionário da mesma instituição, trazendo a idéia de que 
o processo de elegibilidade "finaliza com uma decisão do Estado em relação ao sujeito", mas também pode ser pensado de maneira mais ampla como "exercício de potência dessa pessoa [refugiada] também".

Isso é muito importante da gente perceber. Não é que o status de refugiado seja a grande saída, a solução que todo mundo imagina, mas, ao mesmo tempo, você vê no caso dos venezuelanos, mesmo solicitante de refúgio congolês, como eles se declaram refugiados. Então eles também têm uma definição de refugiado que é construída na convivência que eles têm aqui no Brasil, então tem uma maneira de se apropriar dessa condição que é também muito singular e o que isso significa em termos de direitos que eles querem reivindicar, do estatuto político que não é exatamente o que o Estado imagina (Fernando, Cáritas-Rio).

A apropriação política da condição refugiada atravessou a fala de alguns refugiados e solicitantes, que destacaram a importância de se declararem - e serem reconhecidos como - refugiados. Conforme me contou Guelor, refugiado da RDC:

Pensando politicamente faz diferença, faz muita diferença, entre a gente mesmo, a gente diz muito isso: eu sou refugiado. Afirmar que eu não saí do meu país com plena vontade minha, não, foi forçada de alguma forma, o governo não me protegeu, não, então por isso que eu saí. Até para criticar o país a gente se define mais como refugiado, no dia-a-dia a gente fala isso muito [...] Entre a gente, para a gente se definir, até os que foram negados aqui, a gente se define como refugiado, tipo assim, politicamente falando a gente carrega isso muito mesmo, estou falando os congoleses, a gente carrega isso muito, muito. Como afirmação política com relação ao nosso país, a gente sempre se define assim, o tempo todo (Guelor, refugiado RDC).

Não foi apenas entre os congoleses que a condição refugiada foi ressaltada como afirmação política importante, especialmente para lançar luz sobre a situação de violação de direitos humanos que ocorre em determinados países. Para Javier, solicitante de refúgio da Venezuela, "ser reconhecido como refugiado significa que o Brasil reconhece a verdadeira violação de direitos humanos que tem dentro da Venezuela". Nesse sentido, para o entrevistado, ser reconhecido como refugiado é "uma luta política" pelo reconhecimento do cenário de violações que ocorre em seu país.

Outros refugiados e solicitantes de refúgio, de diferentes nacionalidades, ressaltaram a imagem de que o refugiado é "um guerreiro", afirmando uma posição que se aproxima com a perspectiva da resiliência exposta por alguns funcionários das instituições do universo burocrático do refúgio. Samir, refugiado da Síria, me contou que acredita que "um refugiado significa um guerreiro. Ser refugiado significa que aquela pessoa que carrega nas costas dela aquela memória do seu passado e aqueles sonhos desfeitos, e a saudade da família e da terra, está lutando 
para reconstruir uma nova vida e um novo futuro". Em entrevista com Patrick, refugiado da $\mathrm{RDC}$, esta perspectiva foi novamente trazida à tona:

Refugiado numa palavra eu vou falar guerreiro. Numa palavra só. Por que guerreiro? Porque as pessoas pensam que é fácil, mas não é fácil ser refugiado. Não é fácil sair de uma vida e entrar em outra. Não é fácil mudar sua cabeça, não é fácil aprender uma língua quando você já está maduro. Não é fácil viver como se você não existisse, entendeu?! Você passa na rua, ninguém te conhece. Eu que passava na rua e todo mundo queria me dar bom dia. Mas você fica passando na rua e ninguém te conhece. Não é fácil. Refugiado é um guerreiro. Porque ele gastou tudo o que podia pra salvar a vida. Ele deixou tudo atrás pra estar vivo. O que passou na vida dele se tivesse passando na sua vida você podia desmaiar. Mas ele está vivo. É um guerreiro mesmo, não é coitado. Ao contrário do que as pessoas pensam, ele não é coitado (Patrick, refugiado RDC).

Quando questionados a respeito do que compreendiam sobre a condição refugiada, muitos solicitantes e refugiados desenvolveram suas falas de maneira a criticar a imagem dos brasileiros sobre o refúgio e seus sujeitos, mencionando também a existência de preconceitos e estereótipos em torno do tema. Conforme me contou Tresor, solicitante da RDC, "primeiramente, refugiado não é uma pessoa que cometeu crime no país dele e teve que fugir para cá, não. Refugiado não é uma pessoa que matou alguém e veio para cá pedir refúgio, não". Plamedi, solicitante de refúgio da mesma nacionalidade, afirmou que "o povo daqui quando ele pensa que você é refugiado ele está pensando que você é uma pessoa muito ruim". Prosseguindo sua fala, ele me contou que "chamam a gente de angolano, eles pensam que você nem fez escola e nem fez faculdade, aí depois respeita porque você falou que fez e, se não falou, é uma pessoa muito ruim". O entrevistado também compartilhou comigo uma experiência que classifica como racista, segundo ele: "quando eu cheguei aqui eu não sabia que aqui tem racismo, mas tem. Quando eu fui fazer CPF, uma velha falou que não ia fazer para mim, não. Eu só consegui fazer com outra pessoa, no mesmo lugar".

Guelor também levantou importantes considerações a respeito do racismo e do preconceito que vivencia no Brasil e que compartilha com outros refugiados e solicitantes de refúgio. Ele traz à tona a imagem do "fugitivo" que perpassa as visões de algumas pessoas em relação aos sujeitos em situação de refúgio - imagem essa que também foi levantada, criticamente, por grande parte dos funcionários das instituições que entrevistei.

Quando eu cheguei aqui as pessoas não sabiam dizer refugiado. A pessoa confundia muito com fugitivo entendeu (risos). Até no local do trabalho, os vizinhos... Um primo da minha esposa, podia ser gente boa né, minha esposa me apresentou como refugiado e ele falou: seu marido é, seu noivo na época, seu noivo é fugitivo (risos). 
A minha esposa falou refugiado, mas ele ouviu fugitivo [...] já vi um colega meu contando uma história do avô dele, então eu expliquei que eu sou refugiado, e ele falou: sim, meu avô veio para o Brasil também como fugitivo. Ele usou essa palavra, fugitivo, e aí eu falei: não, mas eu não sou fugitivo, e ele falou: mas é a mesma coisa, refugiado, fugitivo. Também tem isso, então, as pessoas não querem dissociar as coisas, querem misturar tudo, não estão nem aí se vão machucar os outros (Guelor, refugiado RDC, grifo meu).

A recusa ou a incapacidade dos sujeitos se referirem ao termo refugiado, adotando ao invés disso o emprego da palavra "fugitivo", nos permite compreender a possibilidade de uma injustiça hermenêutica permanente e sistemática, que acompanha os refugiados não apenas nas instâncias burocráticas do processo de elegibilidade, mas também em outras áreas de interação na sociedade. Conforme vimos no capítulo teórico desta tese, uma injustiça epistêmica do tipo hermenêutico está associada a interpretações de experiências sociais de determinados grupos que são apresentadas de maneira preconceituosa ou errônea. Nesse sentido, os exemplos que dei anteriormente para a compreensão da injustiça hermenêutica, como o estupro no casamento visto como sexo e a depressão pós-parto entendida como histeria podem ser complementados pela figura do refugiado percebida como equivalente à imagem do fugitivo. Na perspectiva de Fricker (2007), pode haver um preconceito estrutural nos recursos coletivos hermenêuticos que é essencialmente discriminatório, pois os sujeitos são afetados em função de seu pertencimento a determinado grupo social em posição de desvantagem nas relações de poder estabelecidas. Haveria, assim, a manifestação de um preconceito identitário estrutural, uma vez que o processo de marginalização hermenêutica ocorre em função de um aspecto da identidade do sujeito - neste caso, a sua identidade como refugiado.

Guelor compartilhou comigo outras experiências marcadas pelo racismo que vivencia no Brasil, enfatizando a diferença de tratamento concedida aos refugiados e solicitantes que vieram de países da África.

No hotel, as pessoas não aceitam que eu domino o francês, eles ficam sem acreditar, se perguntando: mas ele não é da África, não?! Os brasileiros têm uma imagem muito negativa da África, mas eles falam como se fosse brincadeira: vocês lá moravam junto com os macacos, o seu animal de estimação é um gorila, um leão. Falavam como brincadeira, mas tinha convicção também, que a gente mora junto com os animais. Você tenta explicar, mas tem uma resistência em acreditarem em você. Então você tem que jogar o jogo deles: então, o meu cachorro é um leão, ele é um amigo meu. Aí eles vão abrindo os olhos, dizendo que não é possível. Mas você vê que eles têm isso mesmo na cabeça, acham que todos nós embarcamos escondidos, que ninguém veio de avião, como se não existisse aeroporto na África (Guelor, refugiado RDC). 
A perspectiva do refugiado também sublinha o racismo e o preconceito que existem nas instituições que atuam no processo de refúgio no Brasil, como na Polícia Federal que, segundo ele, "é o pior lugar para os refugiados, infelizmente. Porque você vai sentir esse clima de hostilidade - em alguns, não todos. Eles têm o pensamento de que o estrangeiro é um perigo para o país”. Guelor, já acostumado a acompanhar e orientar pessoas em seus processos de refúgio, afirmou que "na conversa eles diziam como se fosse normal: se fossem da Alemanha, mas da África?! O que eles vieram fazer aqui?! E isso eles falavam comigo mesmo, na minha cara”. Além disso, Guelor traz para a discussão as dificuldades que encontrava no seu trabalho de auxílio aos solicitantes de refúgio, uma vez que os funcionários da Polícia Federal não aceitavam que ele os ajudasse a compreender alguma questão do processo. Conforme ele me contou: "você está vendo que eles não estão entendendo, mas não te deixam explicar, porque se sentem diminuídos, porque um africano está explicando um processo daqui”.

Enquanto muitos entrevistados da RDC relataram episódios de racismo e preconceito, outros solicitantes e refugiados do Marrocos, da Síria e da Rússia narraram o emprego de estereótipos em suas trocas com brasileiros. Conforme Dimitri, solicitante de refúgio da Rússia, me contou: “eles [nós, os brasileiros] pensam que refugiado é homem-bomba, terrorista". Já segundo Samir, refugiado da Síria, "em algum momento alguém me chamou de homem-bomba, terrorista. Eu fugi da guerra para passar por isso. Você não viu o que está acontecendo no meu país?! Como pode alguém discriminar minha chegada?!”. Após seus questionamentos, ele acrescenta: "os refugiados não são terroristas. Os refugiados são vítimas do terrorismo". Ahmed, solicitante de refúgio do Marrocos, também relatou uma experiência similar, em que foi chamado de terrorista e homem-bomba no Brasil quando buscava se informar sobre revalidação de diploma: "um homem falou pra mim: vocês árabes, homem-bomba, terrorista. Eu não falei nada e ele começou a gritar comigo".

Os relatos trazidos por diversos solicitantes e refugiados lançam luz sobre a operação de estereótipos e preconceitos que acompanham os sujeitos não apenas no processo de elegibilidade e com seus atores, mas também nos espaços e momentos de interação com diferentes brasileiros. A perspectiva da injustiça epistêmica que é adotada neste trabalho traz, entre outras contribuições, a visão de Fricker (2007) 
sobre a importância do preconceito e a sua relação com os estereótipos, entendidos como amplas associações entre um grupo e um atributo, produzindo um "compromisso cognitivo com alguma generalização empírica sobre determinado grupo social" (Fricker, 2007, p.31) - por exemplo, refugiados como fugitivos. É possível afirmar, assim, que o estereótipo conectado com um tipo particular de preconceito identitário acaba gerando generalizações empíricas não confiáveis sobre um determinado grupo social. Vemos, então, a produção de uma série de generalizações que associam a figura do refugiado à imagem negativa do fugitivo, à idéia de um sujeito sem formação escolar e acadêmica, à visão do terrorista ou à concepção de um indivíduo com pouco ou nada a contribuir em termos de transmissão de conhecimento. Conforme me contou Guelor, torna-se uma impossibilidade a sua contribuição em explicações sobre o processo de elegibilidade, uma vez que os atores (nesse caso, funcionários da Polícia Federal) não aceitariam o conhecimento advindo dos sujeitos em situação de refúgio. Haveria, assim, a produção de obstáculos no que diz respeito à circulação de idéias e transmissão do conhecimento em sociedade (Fricker, 2007).

\section{7 \\ Conclusões}

As análises desenvolvidas aqui buscaram refletir sobre as práticas da elegibilidade a partir do seu caráter subjetivo, trazendo à tona como os diversos atores deste universo institucional procuram lidar com seus sentimentos e emoções na determinação da condição refugiada. Busquei, assim, um afastamento da dimensão objetiva e burocrática do refúgio por elegibilidade, analisada anteriormente, a fim de que fosse possível refletir sobre a complexidade das avaliações sobre os solicitantes e refugiados nos espaços de troca testemunhal. Nesse sentido, analisei as condições de possibilidade para a produção de uma injustiça epistêmica no modo como diferentes atores percebem seu papel no gerenciamento de expectativas, na busca por vencer incoerências e convencer o outro, no exercício constante da (des) confiança, na gestão complexa das emoções e feelings sobre as "histórias de refúgio", bem como na articulação plural e subjetiva de diferentes significados sobre o que constitui a figura do refugiado. Atravessando estas práticas da elegibilidade, a dimensão subjetiva nos permitiu complementar a 
análise do processo de determinação de status, considerando tanto as dificuldades de participação dos solicitantes e refugiados na produção de significados e transmissão de conhecimento, quanto a existência de uma "economia da credibilidade" (Fricker, 2007) mediada por atores em posições de privilégio epistêmico.

A tentativa de compreender não somente a gramática legal-burocrática que atravessa o processo de elegibilidade, mas também a importância dos aspectos subjetivos demonstrou como a imagem dos "técnicos do refúgio" convive de perto com o quadro de percepções e feelings sobre a determinação da condição refugiada. Ainda que tenha empreendido a separação dessas dimensões em capítulos diferentes, para fins puramente didáticos, é preciso ter em mente que foram as falas dos entrevistados que trouxeram estes aspectos de maneira imbricada. Assim, aos poucos, conforme os atores desenvolveram suas perspectivas, a imagem racional e objetiva do processo se viu lado a lado com uma gestão complexa das percepções subjetivas nas práticas da elegibilidade. Como fio condutor das análises, permaneceu o conceito teórico-filosófico da injustiça epistêmica (testemunhal e hermenêutica), trazendo novamente à tona algumas questões já levantadas, como a existência de posições de privilégio epistêmico, a demanda por determinados estilos e formatos narrativos, e a relação entre déficits e excessos de credibilidade.

A partir disso, um quadro de injustiça epistêmica nas práticas da elegibilidade pode ser compreendido, conforme nos diz Fricker (2007), ao levarmos em consideração os obstáculos à participação ativa dos sujeitos na produção de significados e transmissão de conhecimento, inviabilizando que aspectos importantes das suas experiências sociais e políticas se tornem inteligíveis ao outro, especialmente por meio das trocas testemunhais. Já no que diz respeito especificamente à "economia da credibilidade" (Fricker, 2007), vimos como é possível produzir um quadro de injustiça epistêmica não só por meio da atuação de preconceitos e estereótipos que afetam a credibilidade dos sujeitos, como também através das emoções e percepções subjetivas que impactam a recepção do testemunho do outro (Origgi, 2012), o que contribui para ampliar criticamente a perspectiva teórica de Fricker (2007).

De forma a retomar, brevemente, os argumentos desenvolvidos em cada seção, cabe ressaltar aqui que dei início ao capítulo a partir da análise do gerenciamento das expectativas no processo de elegibilidade. Abordei, assim, as 
práticas direcionadas à tentativa de tradução da "cultura do CONARE" aos solicitantes de refúgio. Procurei mostrar como a condução de entrevistas preparatórias, antes da entrevista com o oficial de elegibilidade do Comitê, evidencia o conhecimento desigual sobre o processo e a existência de uma posição epistêmica privilegiada, com a realização de inferências sobre a confiabilidade dos sujeitos e a busca incessante por encaixar os testemunhos às expectativas existentes. Vimos, assim, o reforço do papel da expertise e a exclusão do conhecimento dos solicitantes de refúgio, com a manutenção de uma estrutura em que a confiança na capacidade explicativa de alguns sujeitos bem posicionados epistemicamente é atravessa pela desconfiança na capacidade de produção e transmissão do conhecimento por aqueles impedidos de desfrutar da mesma posição epistêmica.

$\mathrm{Na}$ segunda seção, foi analisado o trabalho de vencer incoerências nas narrativas e convencer o outro a fim de que os sujeitos pudessem ser reconhecidos como refugiados. As falas dos entrevistados trouxeram a perspectiva de que o convencimento não é uma tarefa a ser empreendida apenas pelo solicitante, mas também pelos membros do CONARE em relação aos seus outros atores. Porém, este trabalho seria realizado de maneiras distintas: o solicitante deve fornecer imagens detalhadas sobre as histórias de perseguição a fim de que seja possível afetar o outro, enquanto os membros do Comitê devem empreender um trabalho racional de levantar argumentos técnicos que auxiliem no convencimento de outros atores envolvidos no processo decisório. Neste contexto, procurei refletir sobre a necessária abertura a erros de julgamento, levando em consideração não somente barreiras lingüísticas e traumáticas que possam afetar a inteligibilidade da troca testemunhal, mas também o necessário fracasso de todo projeto autonarrativo (Butler, 2017). Seria preciso compreender, assim, que a incoerência não se restringe aos testemunhos dos solicitantes de refúgio, tornando imprescindível o monitoramento do papel que reações emocionais, por exemplo, podem desempenhar nos julgamentos de credibilidade.

$\mathrm{Na}$ seção seguinte o papel da (des) confiança foi analisado a partir da reflexão a respeito da necessidade de produzir um ambiente de confiança para que o solicitante de refúgio possa narrar sua história. Os entrevistados trouxeram a perspectiva de que o vínculo de confiança do solicitante no entrevistador seria fundamental para o sucesso da solicitação de refúgio. Porém, no que diz respeito à confiança do oficial no solicitante, algumas entrevistas permitiram apontar a 
existência de uma postura de desconfiança que impacta negativamente a troca testemunhal. Seria possível afirmar, assim, que não há apenas uma prática investigativa, voltada para a identificação de supostas contradições nas narrativas dos sujeitos, mas também uma postura de confrontação direta. Nesse sentido, a ênfase sobre a confiança do solicitante no oficial parece menosprezar a relevância das avaliações que determinam por quais motivos o oficial decide confiar ou desconfiar de determinados sujeitos. Mais do que a preocupação sobre um ambiente de confiança para o solicitante compartilhar sua história, emerge a necessidade de refletir sobre como as práticas nesse universo abarcam percepções e julgamentos subjetivos sobre a credibilidade dos solicitantes, avaliados e valorados a partir da confiança que pode ou não ser estabelecida em seu testemunho.

A quarta seção buscou abordar o papel central que o sentimento, ou a percepção subjetiva, desempenha nos julgamentos de credibilidade e, assim, no processo decisório como um todo. O caráter subjetivo do refúgio por elegibilidade e a permanência de dúvidas mesmo após a tomada de decisão emergem neste cenário a partir das falas de alguns entrevistados. Vimos, assim, a busca que determinados atores desempenham para compreender o sentimento dos solicitantes e ser afetados pelos seus testemunhos a fim de que seja possível atribuir ou não credibilidade. A percepção subjetiva dos atores envolvidos neste universo também emerge das falas sobre os critérios utilizados na análise de credibilidade com menções a uma espécie de feeling sobre a autenticidade dos sujeitos e suas solicitações de refúgio. A partir disso, é possível compreender como o impacto de julgamentos em uma economia da credibilidade não é determinado apenas pela operação de estereótipos e preconceitos, mas também por fatores importantes como as reações emocionais (Origgi, 2012).

Por fim, procurei abordar, na última seção, os diferentes significados atribuídos à figura do refugiado por alguns dos atores que compõem o universo institucional brasileiro, podendo contribuir para a produção de um excesso que dificulta a capacidade de uma troca testemunhal inteligível sobre a experiência social daqueles em situação de refúgio. Busquei, ainda, trazer a contribuição dos próprios solicitantes e refugiados a respeito desta condição, com o levantamento de críticas em relação ao que concebem como a existência de preconceitos e estereótipos em suas relações com diversos brasileiros. Esta seção final procurou refletir, então, sobre a produção de uma série de concepções distintas sobre o que 
constitui a condição refugiada, realizada a partir de posições de privilégio epistêmico que produzem significados ao mesmo tempo em que podem excluir do processo a participação ativa dos solicitantes e refugiados. Cabe salientar aqui, porém, que o capítulo seguinte trará uma análise midiática mais sofisticada sobre a produção de significados a respeito da condição refugiada e o que isso pode implicar em termos de uma injustiça epistêmica, especialmente em sua dimensão hermenêutica. Veremos, em maiores detalhes, como obstáculos à inteligibilidade das experiências dos sujeitos refugiados e à sua participação na produção de significados e transmissão de conhecimento não estão restritos às práticas da elegibilidade, mas encontram terreno fértil no campo midiático. 


\section{5 \\ O campo semântico do refúgio no Brasil: A produção de significados pela mídia e a injustiça epistêmica}

\section{Resumo}

Tendo como recorte de pesquisa a categoria do refugiado, este capítulo pretende analisar a produção de significados sobre o sujeito em situação de refúgio. A partir disso, a pergunta que guiará esta reflexão é: como pensar os significados atribuídos ao refugiado pela grande mídia brasileira no período entre 2013 e 2017? Para tanto, será utilizada uma abordagem de análise com corpus que, a partir do uso de softwares, e técnicas específicas, ajuda a acessar e interpretar o material compilado dos jornais online e portais de notícias mais acessados no Brasil. As análises realizadas são compostas tanto por uma dimensão léxica, que aborda o conjunto de palavras mais utilizadas em referência à categoria de refugiado, quanto por uma dimensão gramatical, que trata da agência gramatical por meio dos verbos dos quais o refugiado é sujeito e objeto. Assim, fazendo uso de uma perspectiva analítica que reúne a riqueza de abordagens quantitativas e qualitativas, o texto expõe uma reflexão sobre o campo semântico do refúgio no Brasil e os espaços de habitação possível na mídia para quem se encontra na condição refugiada. Retomarei, ainda, as discussões sobre injustiça epistêmica, distanciando-me do debate sobre o refúgio por elegibilidade para aproximar-me da reflexão sobre a injustiça hermenêutica no espaço da representação midiática sobre os refugiados.

Palavras-chave: Corpus; Representação; Mídia; Injustiça Hermenêutica.

\section{1 Introdução}

Os sujeitos em busca de refúgio, e categorizados como refugiados, percorrem diversos espaços que não se restringem às linhas imagináveis e altamente policiadas que demarcam fronteiras territoriais, mas também envolvem os lugares da burocracia, da assistência humanitária, das instituições acadêmicas e, claro, da grande mídia. Cada espaço é composto por sua própria rede de processos, atores e dinâmicas que procuram atuar sobre tais sujeitos e, em menor medida, junto aos mesmos. De maneira complexa e imperfeita, tais espaços ajudam a produzir diferentes regimes de visibilidade e produção de conhecimento que são construídos como espaços possíveis de habitação para os sujeitos em situação de refúgio. Ainda que o exercício de poder possa ser visto como uma teia de relações que também se deparam com a potência e a insubordinação daqueles que resistem a diversas dinâmicas de opressão, parece-me necessário pensar sobre a constituição do refúgio 
como um espaço de produção de formas globalizadas de injustiça. É, assim, a partir desse contexto mais amplo que orienta os interesses da pesquisa, que irei abordar aqui a produção do campo semântico do refúgio no Brasil ${ }^{43}$.

Se nos capítulos anteriores procurei analisar o espaço epistêmico do refúgio por elegibilidade no Brasil, a fim de que fosse possível refletir sobre a produção de formas de injustiça epistêmica nas trocas testemunhais e no processo como um todo, neste capítulo busco analisar a questão da injustiça hermenêutica na representação midiática do refugiado. Embora as discussões anteriores tenham levantado em alguns momentos o debate sobre a injustiça hermenêutica, uma vez que há uma interligação entre os dois âmbitos da injustiça epistêmica (testemunhal e hermenêutica), a ênfase maior das análises recaiu sobre a manifestação testemunhal da injustiça no campo do refúgio por elegibilidade. Tendo isso em mente, acredito que seja crucial, para fins de compreensão do debate sobre o refúgio como injustiça epistêmica, uma discussão mais detalhada sobre a baixa inteligibilidade que já toca a vida dos sujeitos em situação de refúgio no âmbito do social. Nesse sentido, tornase necessário refletir sobre a inteligibilidade da experiência do refúgio através dos significados atribuídos pela mídia brasileira aos refugiados.

Conforme vimos no decorrer desta tese, enquanto na injustiça testemunhal teríamos alguém injustiçado na sua capacidade como sujeito do conhecimento, na injustiça hermenêutica teríamos alguém injustiçado em sua capacidade como sujeito da compreensão social (Fricker, 2007). Dessa maneira, busco analisar não somente o campo do refúgio por elegibilidade, com seus processos e mecanismos de produção de significados sobre o que constitui o refugiado, mas também a dimensão mais ampla do social com a produção dos significados pela grande mídia brasileira. Torna-se crucial refletir aqui sobre como os sujeitos em condição de refúgio podem constituir um grupo social em desvantagem hermenêutica, no sentido proposto por Fricker, isto é, como um gap nos recursos hermenêuticos coletivos que impede ou dificulta a compreensão necessária da experiência social vivenciada pelos membros deste grupo. É, nesse sentido, que o presente capítulo busca compreender não só algumas percepções sociais midiáticas sobre o refugiado,

\footnotetext{
${ }^{43} \mathrm{O}$ objetivo da análise gira em torno da busca pela compreensão de como a figura do refugiado é construída e representada pela mídia brasileira. Isso não significa, porém, que analisarei apenas notícias e matérias sobre refugiados no Brasil. Levarei em consideração, assim, as reportagens que tratam do tema extrapolando o contexto brasileiro.
} 
com uma pluralidade de significados produzidos, mas também a falta de um lugar comum de troca que permita tornar inteligível a experiência social do refúgio a partir da contribuição dos próprios sujeitos.

Nos capítulos anteriores vimos como ocorre, no seio do processo de elegibilidade, a desapropriação das narrativas e o desaparecimento dos sujeitos, cada vez mais subsumidos pela burocracia e pela "economia da credibilidade". Neste capítulo final, por sua vez, torna-se possível compreender uma espécie de continuidade desta dinâmica nas práticas de representação midiática da experiência do refúgio. Buscarei discutir, a partir dos resultados da análise com corpus, como a ausência da participação ativa dos refugiados no processo de produzir significados sobre suas experiências está ligada a um empobrecimento e uma marginalização nos recursos coletivos hermenêuticos. Estes acabam se tornando, assim, estruturalmente preconceituosos, uma vez que há interpretações das experiências sociais da condição refugiada que podem ser vistas como tendenciosas, por não serem influenciadas pelos sujeitos em situação de refúgio, mas por membros de grupos hermeneuticamente mais poderosos (Fricker, 2006). O empobrecimento e a marginalização hermenêutica acompanham, assim, a vida dos refugiados, escapando dos espaços da elegibilidade e determinando a imagem do refúgio para além dos processos oficiais de determinação do status.

A fim de analisar a produção de significados sobre o sujeito refugiado irei trabalhar com o que chamo aqui de "grande mídia", que pode ser entendida como os jornais online e portais de notícias mais acessados a partir do Brasil. São eles: Globo; Uol; Abril; Gazeta do Povo; Elpaís; Isto é. A escolha de tais nomes se deu através da utilização da ferramenta do Google, "similar web", que dispõe publicamente, de forma atualizada, os dez primeiros sites mais acessados no Brasil. Dentre tais sites, quatro (Yahoo; MSN; Folha; Estadão) foram excluídos da pesquisa por questões técnicas, como problemas na compilação das matérias, caso de Folha e Estadão, por não produzirem conteúdo próprio e/ou por apresentarem repetição de matérias já compiladas em outro jornal ou portal (Yahoo e MSN). Quanto ao recorte temporal escolhido, o período entre 2013 e 2017 será utilizado em função dos dados disponíveis sobre o número de solicitações de refúgio no Brasil. Segundo o relatório do Ministério da Justiça (2017), houve um aumento exponencial nas solicitações de refúgio no país a partir de 2013, o que pode ter levado a um subseqüente aumento na representação midiática desse grupo de 
pessoas. Ainda que não tenha sido possível fazer uma análise anual do número de matérias sobre refugiado nos sites trabalhados, parto da premissa de que o aumento do fluxo de pessoas solicitando refúgio no Brasil acaba tendo efeitos sobre a exposição midiática, se não pontualmente a partir de 2013 , ao menos de forma gradual no período sob análise.

A pesquisa realizada aqui só é possível graças ao uso de uma metodologia desenvolvida no contexto dos estudos com corpus, que utiliza softwares como programas auxiliares para a análise de uma coleção ampla de textos em formato eletrônico, usualmente vistos como uma amostra representativa do objeto de estudo compilada segundo critérios variados, como circulação e período de tempo, por exemplo. Tendo em mente tal representatividade, a análise com corpus pode ser entendida como partindo de um material amplo o suficiente para revelar determinados padrões no uso da linguagem em referência a determinado tema. Ainda que haja debates, sobre os quais não me deterei aqui, acerca da análise com corpus como uma metodologia ou como uma teoria da linguagem (ou mesmo como ambas), o que considero fundamental deixar claro é que tal análise pode ser vista, para fins didáticos e explanatórios, da seguinte maneira: uma análise de uma coletânea de textos autênticos, compilados segundo critérios pré-estabelecidos, legíveis pelo computador, que utiliza ferramentas específicas para auxiliar o pesquisador na interpretação do seu material compilado.

A lingüística com corpus, como é comumente chamada esta metodologia ou abordagem teórica, emerge, assim, como um campo da lingüística que permite a análise de um conjunto amplo de material (escrito ou oral) a partir da junção de abordagens quantitativas e qualitativas. Torna-se possível, então, reunir as potencialidades "quanti-quali" (Baker et.al., 2008), trazendo para o processo suas principais contribuições e deixando de lado preconceitos que demarcam as fronteiras entre as diferentes áreas de pesquisa na tentativa de fazer do mundo algo menos complexo e mais rentável.

Mesmo diante da necessidade de softwares para auxílio desde a compilação até a interpretação dos textos, considero como fundamental a presença ativa (e subjetiva) da pesquisadora em todas as etapas do processo, desde a escolha dos critérios para a compilação do material, passando pelo esforço da criação de categorias e da interpretação dos dados, até as conclusões e teorias daí derivadas. Nesse sentido, é necessário levar em consideração que o processo analítico parte 
não somente de critérios objetivos e facilmente justificáveis, pré-estabelecidos e expostos anteriormente, como também dependem da minha própria trajetória pessoal e interesse de pesquisa. Não procuro endossar, assim, uma visão de objetividade como um estado de desengajamento que constituiria um suposto observador desinteressado, mas reforço a perspectiva do engajamento do pesquisador no tema como algo valioso e inevitável a ser mobilizado (Leander, 2015). Tal perspectiva revela-se como importante aqui não só pela sua relação com a coletânea definida para pesquisa, cujos critérios mais objetivos já foram elencados anteriormente, mas também pela sua estreita relação com o processo de categorizar o material sob análise, permitindo um determinado tipo de interpretação que poderia variar de acordo com a pergunta de pesquisa e com o olhar subjetivo da pesquisadora.

O presente capítulo será desenvolvido da seguinte maneira: inicialmente, farei uma breve exposição sobre estudos relacionados, isto é, trarei alguns dos principais trabalhos com corpus no tema do refúgio/migração, discutindo como os autores empregaram este tipo de abordagem e quais foram os principais resultados obtidos. Em seguida, apresentarei em maiores detalhes a minha análise com corpus, não de forma a explicar todo seu funcionamento, mas sim de maneira a especificar quais de suas várias ferramentas foram utilizadas na pesquisa e como elas podem ser entendidas. Não deixarei de levar em conta o processo de categorização do material, tendo em vista que as categorias são fundamentais para o trabalho de interpretação dos textos. Posteriormente, irei expor os resultados da análise em dois tópicos inter-relacionados: análise léxica, com o conjunto de palavras mais utilizadas para fazer referência ao termo "refugiado", e análise gramatical, com o conjunto de verbos dos quais o refugiado é sujeito e objeto nos textos. Por fim, uma seção sobre o campo semântico do refúgio no Brasil e a injustiça epistêmica (em sua dimensão hermenêutica) irá reunir reflexões a partir dos resultados das análises anteriores e também de forma mais ampla considerando as discussões teóricas existentes.

Cabe salientar, ainda, que o material foi analisado em diversas etapas: a) cada jornal online e portal de notícia foi analisado em separado; b) os jornais foram comparados entre si; c) os portais foram comparados entre si; d) jornais e sites foram comparados uns com os outros; e) ao observar poucas variações nas análises, o material foi analisado de maneira conjunta, como um só corpo reunindo toda a 
mídia. A exposição dessas análises será feita de acordo com o interesse da pesquisadora em respeitar uma apresentação interessante e didática do material, sem sobrecarregar o leitor com gráficos e tabelas, porém sem deixar de expor as informações comentadas de cada subcorpus.

\section{2 \\ Estudos com corpus sobre a representação de imigrantes e refugiados}

Alguns estudos importantes já foram realizados no campo de interseção entre migração/refúgio, representação midiática e análise com corpus (Archer e Rayson, 2004; Berglund Prytz, 2016; Fotopoulos e Kaimaklioti, 2016; Gabrielatos e Baker, 2008; O’Regan e Riordan, 2018; Strom e Alcock, 2017; Taylor, 2014), especialmente no contexto europeu. É preciso ressaltar, porém, que o objetivo desta seção não é detalhar as discussões existentes nesta área, nem mesmo prover uma revisão de literatura ou estado da arte sobre o tema. De forma específica, o que procuro alcançar aqui é a localização da minha análise entre as pesquisas existentes e seus vários modos de abordar a temática da representação dentro da abordagem com corpus. A partir disso, ficará mais claro para os leitores como esta análise se aproxima ou se afasta dos estudos existentes e como ela pode contribuir para preencher um gap de pesquisa, em um quadro analítico em que faltam trabalhos desenvolvidos sobre - e desde - o Brasil.

Ainda que haja muitas discussões sobre mídia, representações e até lingüística com corpus como temas independentes, o maior interesse aqui é na interseção entre migração/refúgio, representação midiática e análise com corpus. Considero que há um potencial ainda em grande medida inexplorado no que diz respeito a análises, desde perspectivas situadas, que buscam aplicar metodologias e ferramentas da análise com corpus a fim de compreender as representações midiáticas sobre o tema da mobilidade. Foi precisamente este o esforço empreendido por Strom e Alcock (2017) com o objetivo de responder à questão de como a mídia mainstream dos Estados Unidos representa crianças latinas desacompanhadas. As autoras consideraram que "embora a representação de imigrantes na mídia mainstream tenha sido um foco central nos estudos críticos do discurso, poucos estudos tem considerado o modo como a mídia mainstream representa crianças imigrantes" (Strom e Alcock, 2017, p.2). A partir deste gap 
identificado pelas autoras, particularmente no contexto norte-americano, o estudo desenvolveu a perspectiva de que a mídia representa este grupo específico como um problema que deveria ser removido ao invés de, por exemplo, representá-lo como sujeito de cuidado.

A análise desenvolvida por Strom e Alcock buscou identificar aspectos léxicos e gramaticais na representação midiática do grupo estudado. Foram analisados tanto os termos lexicais associados com o termo de busca quanto os aspectos gramaticais, com um foco em processos verbais e atores sociais que empreenderam tais processos. $\mathrm{Na}$ análise léxica, as autoras enfatizaram termos associados com água, como onda e inundação, uma vez que foram aqueles que apareceram com mais freqüência nas frases. Já na análise gramatical, elas buscaram identificar quais participantes ou atores realizaram as ações associadas com os termos léxicos enfatizados. O que é importante ressaltar aqui é que o estudo que desenvolvo se inspirou na abordagem de Strom e Alcock em relação a uma análise de aspectos léxicos e gramaticais na representação midiática do grupo. Entretanto, não busco focar na análise apenas de termos específicos, mas ofereço uma visão geral dos termos léxicos e processos verbais tendo em vista sua freqüência no material e sua inserção em contextos específicos.

Apesar da análise desenvolvida por Strom e Alcock (2017) ser fundamental para compreensões acerca da representação midiática nos Estados Unidos em relação a crianças imigrantes, não é possível se basear em seu trabalho a fim de compreender a metodologia com corpus aplicada para a análise do material. Ao ler o trabalho, não pude saber quais foram os passos adotados pelas autoras na abordagem e, assim, poderíamos dizer que a análise não é replicável. Tendo isso em mente, o presente estudo guarda maior proximidade com o trabalho de Archer e Rayson (2004) sobre como um sistema de análise semântica poderia ser utilizado para a análise de conteúdo de Forced Migration Online (FMO). Apesar da diferença temática, busco, assim como os autores, não somente empregar a terminologia específica na análise com corpus, mas também explicar seus significados e expor detalhadamente os passos adotados no estudo a fim de que seja possível replicá-lo.

A busca pela transparência no que diz respeito à abordagem adotada aqui é importante, assim, para que seja possível compreender a metodologia empregada, especialmente aqueles que não possuem familiaridade no campo da análise com corpus, bem como replicar o estudo. Conforme nos diz Taylor (2014), a 
possibilidade de replicar a pesquisa é fundamental para permitir a falsificação e também a extensão do estudo e sua aplicação em diferentes contextos. Nesse sentido, e assim como Taylor em sua análise da representação de imigrantes na mídia da Itália e do Reino Unido, o presente estudo está interessado na possibilidade de uma para-replicação em diferentes culturas, períodos temporais e em relação a diferentes sujeitos da cobertura midiática. É com isso em mente que busco detalhar na próxima seção os métodos de coleta e análise do material.

Outra importante contribuição no campo da interseção entre migração/refúgio, representação midiática e análise com corpus é o trabalho desenvolvido por Gabrielatos e Baker (2008) sobre a construção discursiva dos refugiados e solicitantes de refúgio pela mídia do Reino Unido. De acordo com os autores, "a maior parte da pesquisa lingüística sobre questões de refúgio e imigração adota a perspectiva da análise crítica do discurso, que tradicionalmente desenvolve uma análise detalhada de uma pequena amostra de textos" (Gabrielatos e Baker, 2008, p.6). Como uma conseqüência desse tipo de análise, "a análise crítica do discurso tem sido criticada por uma seleção arbitrária de textos, o que lança dúvidas sobre sua representatividade, e por uma análise de um número pequeno de textos ou fragmentos de textos, o que não pode revelar padrões úteis [...]” (idem). Com tais críticas em mente, a análise que desenvolvo aqui também espera contribuir para preencher as lacunas em relação a questões de representatividade e padrões observáveis no material. Nesse sentido, estou interessada não somente em permitir que o corpus seja representativo, mas também em apontar padrões através da análise detalhada de uma grande quantidade de textos.

Também é importante reconhecer a existência de um relatório, publicado em 2013, do Observatório das Migrações (Migration Observatory), da Universidade de Oxford, intitulado "Migration in the News: Portrayals of Immigrants, Migrants, Asylum Seekers and Refugees in National British Newspapers, 2010-2012”. Neste relatório, é realizada uma análise com corpus da linguagem de todos os vinte jornais britânicos. O relatório adota um método de análise que também é empregado aqui: o exame das palavras mais freqüentes que acompanham o termo de busca da pesquisa - neste presente estudo, as palavras próximas ao termo "refugiado" e suas variações. Os principais resultados, expostos pelo documento, mostram que a cobertura midiática sobre migração e refúgio inclui o vocabulário dos números, discursos de segurança ou legalidade e a linguagem da 
vulnerabilidade. $\mathrm{Na}$ análise realizada aqui, alguns desses vocabulários também são trazidos à tona a partir do exame do material, permitindo uma melhor compreensão de como a grande mídia brasileira representa os refugiados - e o que isso pode significar em termos de produção de uma injustiça epistêmica.

Conforme vimos com a breve exposição de alguns estudos no campo da análise com corpus aplicada à discussão sobre migração/refúgio e representação midiática, há uma lacuna significativa no que diz respeito ao desenvolvimento de pesquisas desde contextos locais, especialmente no caso brasileiro. Há, nesse sentido, um potencial inexplorado de análise com corpus que permita a produção de modos de compreensão sobre como a grande mídia no país representa determinados grupos sociais, em especial os sujeitos em situação de refúgio. Tendo em vista esta ausência, e a seriedade da pesquisa, busco apresentar em detalhes na próxima seção como o material é constituído e analisado, aproveitando o espaço para introduzir os leitores pouco familiarizados com a abordagem aos termos e procedimentos de uma análise com corpus.

\section{3}

\section{A abordagem com corpus: guia para a pesquisa}

Uma análise com corpus aborda uma coletânea ampla de textos, uma vez que necessita atuar como uma amostra representativa de uma determinada linguagem nos dizendo algo significativo sobre padrões existentes no discurso (Baker, 2010). Para tanto, não é possível realizar uma análise apenas manual, o que nos leva ao papel fundamental das ferramentas criadas para manipulação de um grande corpo de arquivos de texto. Assim, cabe destacar aqui que a pesquisa contou com a utilização de duas ferramentas específicas (e gratuitas) que auxiliam neste tipo de análise: a primeira delas, BootCat ${ }^{44}$, foi utilizada a fim de ajudar no processo de compilação dos sites e arquivos que formariam o corpus; a segunda, AntConc ${ }^{45}$, foi utilizada para realizar especificamente a análise do material importado a partir da ferramenta anterior. A partir disso, foi possível analisar, em um período de cinco (5) anos, de 2013 a 2017, em seis (6) jornais e portais de notícias, um total de 1.145 arquivos de texto, com um corpus final de 750.868 palavras.

\footnotetext{
${ }^{44}$ https://bootcat.dipintra.it/?section=home

${ }^{45}$ https://www.laurenceanthony.net/software/antconc/
} 
Através das ferramentas computacionais específicas, é possível identificar alguns padrões de linguagem e freqüências que permitem a interpretação do material e a comparação entre subcorpus, caso existam. Na pesquisa apresentada aqui, o termo de busca, isto é, o termo que orientou todo o processo de análise, foi "refugiado" e suas variações ${ }^{46}$ (refugiada; refugiados; refugiadas). A análise com corpus teve início, assim, a partir de algumas ferramentas fundamentais, disponíveis no software utilizado, sempre orientadas pelo termo de busca escolhido. A primeira dessas ferramentas, chamada keyword list, traz o conceito central de keyness, isto é, freqüências mais altas e significativamente relevantes de palavras em comparação com um corpus de referência (Baker et.al., 2008). Assim, fazendo uso de outro corpus, sobre tema diverso, o software foi capaz de processar aquelas palavras-chave do material que apareciam com mais freqüência e eram especificamente relevantes para o corpus da pesquisa, conforme será demonstrado na próxima seção.

Após a produção da lista de palavras-chave no conjunto de textos, foi utilizada uma ferramenta que nos mostra a importância da técnica qualitativa: a análise das linhas de concordância. O software utilizado pode apresentar ou ordenar as linhas de concordância de formas variadas, mas não pode interpretá-las - fica a cargo da pesquisadora a exploração dos casos individuais (linha por linha) detalhadamente (Baker, 2010). Como "linhas de concordância" entendem-se os trechos das frases que constam o termo de busca e as palavras que o acompanham, à direita e à esquerda no texto. A análise das linhas de concordância requer, assim, uma análise mais manual em que o software pouco ajuda na identificação de padrões lingüísticos e na verificação dos sentidos e significados das palavras que acompanham o termo de busca.

A análise com corpus levada a cabo pela pesquisa também trabalhou com outra ferramenta essencial nesse tipo de abordagem: collocation. A ferramenta apresenta os termos ou palavras que co-ocorrem no material analisado que, tendo em vista as freqüências de ocorrência, podem representar padrões na forma como um determinado tema é abordado. Em outras palavras, "a co-ocorrência de termos estabelece uma moldura para o entendimento de um tópico particular" (Strom e Alcok, 2017, p.11). Nesse sentido, a relação freqüente entre certos termos ou

\footnotetext{
${ }^{46} \mathrm{~A}$ fim de fazer referência ao termo de busca e suas variações, será empregada aqui a mesma forma utilizada no software - "refugiad*".
} 
palavras pode demonstrar padrões de representação de um determinado tema, como, por exemplo, a ocorrência freqüente do termo "ilegal" associado a "imigrante" (collocate - imigrante ilegal). É possível, assim, organizar uma lista dos principais collocates associados à direita e à esquerda do termo de busca, analisando as construções mais freqüentes no material.

Uma análise com corpus pode ser vista como uma abordagem "corpusdriven" ou "corpus-based" (ou ambas). A primeira delas é entendida como uma análise que se deixa guiar pelo material, isto é, pelo que é freqüente ou saliente nos dados; enquanto a segunda pode ser compreendida como uma forma de permitir o teste de hipóteses ou teorias pré-existentes (Baker, Gabrielatos e Mcenery, 2012). Nesta pesquisa foi utilizada a abordagem "corpus-driven", uma vez que, pela utilização das ferramentas mencionadas nos parágrafos anteriores e pela análise das frequiências, foi possível criar algumas categorias analíticas fundamentais. Assim, através da análise manual das linhas de concordância foi possível notar alguns padrões de palavras associadas ao termo de busca, tendo início um trabalho qualitativo de refletir detalhadamente sobre como agrupar tais palavras em categorias que fizessem sentido a partir do material. Dessa maneira, por meio da análise manual da concordância, que permite visualizar os elementos do contexto, os termos mais freqüentes foram examinados e agrupados em categorias temáticas. Temos, então, o emprego não só do método quantitativo a fim de dar conta dos padrões e repetições no material, mas também a utilização do método qualitativo para agrupar e categorizar termos segundo possibilidades de significação propostas pela pesquisadora.

A categorização emerge, assim, como processo central para a análise proposta aqui. É preciso considerar, porém, que a produção de categorias opera de forma a simplificar uma realidade altamente complexa, reduzindo uma infinidade de variações (na linguagem ou na experiência) a um conjunto reduzido de categorias (Ellis, 1993). O ordenamento a partir do que é essencialmente caótico constitui parte essencial do processo de categorização, que, segundo Ellis, não só busca simplificações, como também procura formular abstrações para desenhar regularidades a partir do observado. O processo de categorizar assume, como uma de suas funções principais, a tentativa de criação da ordem ao reunir, em uma mesma categoria, aquilo que pode ser interpretado como similar, ao passo que busca excluir aquilo visto como diferente. Ao mesmo tempo, tal processo guarda sua 
utilidade fundamental, uma vez que, como nos diz Ellis, cria-se a possibilidade de conhecimento que emerge somente da nossa capacidade de conhecer aspectos das situações e nos orientar em um mundo altamente complexo. Podemos interpretar, então, que o caráter arbitrário de toda categorização se baseia, fundamentalmente, nos nossos propósitos (Ellis, 1993). As categorias criadas aqui representam, assim, não a tentativa de refletir objetivamente as estruturas do mundo, mas de garantir funcionalidade aos tratamentos de padrões e repetições observados durante a pesquisa.

Tendo em mente as particularidades do processo de categorização, destaco aqui a criação de oito categorias analíticas que foram observadas no processo de análise do corpus explicitado anteriormente, tendo como ponto de partida fundamental a análise das linhas de concordância em todos os subcorpus. Em outras palavras, na análise da concordância em cada site e portal de notícia trabalhado, as mesmas categorias puderam ser criadas e observadas em seus respectivos contextos. Tais categorias criadas são: quantidade; nacionalidade; local; cuidado; crise; movimento; status e controle ${ }^{47}$. Assim, da leitura manual das linhas de concordância observei alguns padrões no que diz respeito às palavras mais freqüentes que acompanhavam o termo de busca. A partir de tais categorias, que serão discutidas em detalhes no decorrer do capítulo, e reconhecendo o papel subjetivo da pesquisadora no processo criativo, proponho a análise léxica e gramatical do corpus da pesquisa de acordo com os resultados encontrados.

\section{4}

\section{Resultados da análise léxica e gramatical}

A análise léxica de cada subcorpus da pesquisa (Uol; Globo; Abril; Gazeta; Elpaís; Istoé) verificou as linhas de concordância, collocation, keyword list, e frequiências, a fim de que fosse possível interpretar o conjunto de palavras mais usadas para fazer referência ao termo de busca "refugiad*". Em cada um desses subcorpus foi possível trabalhar com todas as categorias mencionadas anteriormente, tendo em vista que permaneciam aquelas mais utilizadas no material para a representação do sujeito refugiado em diferentes contextos.

\footnotetext{
${ }^{47}$ Respeitando o processo original de análise do corpus, a exposição dos resultados comentados irá trazer a categoria "controle" apenas a partir da análise gramatical, tendo em vista que foi nesta dimensão da análise que tal categoria analítica foi observada pela pesquisadora.
} 
Antes de expor os resultados da análise léxica do material, cabe trazer alguns dados sobre cada um dos subcorpus trabalhados na pesquisa, a fim de que seja possível visualizar o tamanho dos conjuntos de textos que os constituem. Para tanto, a tabela 1 apresenta a quantidade de palavras totais (tokens), de palavras sem repetição (types), de arquivos de texto (matérias dos portais e jornais) e do termo de busca "refugiad*", que aparecem em cada subcorpus.

Tabela 2: Composição de cada subcorpus

\begin{tabular}{|c|c|c|c|c|}
\hline Subcorpus & Word Types & Word Tokens & Arquivos & "Refugiad"” \\
\hline Uol & 12.438 & 105.261 & 190 & 1346 \\
\hline Globo & 11.355 & 106.980 & 196 & 1615 \\
\hline Abril & 11.438 & 119.439 & 193 & 2140 \\
\hline Gazeta & 14.929 & 135.853 & 199 & 1096 \\
\hline Elpaís & 16.846 & 168.232 & 200 & 1551 \\
\hline Istoé & 14.539 & 115.103 & 166 & 621 \\
\hline Total & 35.458 & 750.868 & 1145 & 8369 \\
\hline
\end{tabular}

Em termos de keywords list, uma das primeiras ferramentas utilizadas na análise léxica, as palavras-chave especificamente relevantes no material da pesquisa não apresentaram variação significativa de um subcorpus para outro, conforme podemos observar na tabela 2 abaixo, apresentando as cinco palavraschave mais freqüentes: 
Tabela 3: Keywords por subcorpus

\begin{tabular}{ll}
\hline Subcorpus & Keywords
\end{tabular}

Uol

Refugiados; Síria; Imigrantes; Europa; Brasil.

Globo

Refugiados; Países; Sírios; Imigrantes;

Milhões.

Abril

Refugiados; Imigrantes; Fronteira; Síria;

Mundo.

Gazeta

Refugiado; Imigrantes; Síria; Sírios; Europa.

Elpaís

Refugiados; Países; Imigrantes; Turquia;

Europa.

Istoé

Refugiados; Países; Imigrantes; Trump; Brasil.

Além da lista de palavras-chave, a análise por collocation, ordenada por frequiência, fez emergir as palavras mais associadas ao termo de busca, em uma janela de amplitude de duas (2) palavras para a direita e para a esquerda do termo. Os resultados encontrados em cada subcorpus foram interpretados como homogêneos, com poucas variações entre eles. Assim, para fins didáticos, a tabela 3 expõe os collocates do corpus geral (incluindo todos os sites e portais de notícias trabalhados aqui). 
Tabela 4: Collocates mais freqüentes do termo "refugiad*"

Collocates Frequência

Sírios

575

Campo(s)

468

Crise

Número

176

Receber

A análise por collocation ajudou no processo de categorização do material, uma vez que demonstrou a relevância das categorias temáticas criadas através da análise manual das linhas de concordância. Em outras palavras, as categorias mostraram-se significativas já que não apareciam somente através da análise qualitativa e manual da pesquisadora e, portanto, subjetiva e tendente a possíveis falhas, mas também através da análise estatística do software dos padrões de representação associados ao termo de busca. Embora eu tenha apresentado, na tabela 3, somente os collocates de maior freqüência no corpus geral da pesquisa, todas as categorias criadas aparecem de maneira significativa em cada subcorpus trabalhado. As categorias são discutidas em maiores detalhes abaixo. 
Tabela 5: Categorias e Termos Associados

\begin{tabular}{|c|c|}
\hline Categorias & Termos \\
\hline Quantidade & Número; Mil; Milhões; Milhares. \\
\hline Nacionalidade & $\begin{array}{l}\text { Sírios; venezuelanos; palestinos; africanos; } \\
\text { afegãos; iraquianos; angolanos. }\end{array}$ \\
\hline Local & Campo; centro; abrigo; região. \\
\hline Cuidado & $\begin{array}{l}\text { Abrigar; acolher; assistir; ajudar; acomodar; } \\
\text { proteger; amparar. }\end{array}$ \\
\hline Crise & $\begin{array}{l}\text { Crise }- \text { não foram encontrados termos } \\
\text { similares. }\end{array}$ \\
\hline Movimento & $\begin{array}{l}\text { Fluxo; entrada; onda; fuga; saída; entrar; sair; } \\
\text { cruzar; cruzamento; travessia; atravessar. }\end{array}$ \\
\hline Status & $\begin{array}{l}\text { Visto como; reconhecido como; tratado como; } \\
\text { aceito como; considerado como; definido } \\
\text { como; registrado como; status como. }\end{array}$ \\
\hline
\end{tabular}

Abrigar; acolher; assistir; ajudar; acomodar; proteger; amparar. similares

Nacionalidade. A categoria nacionalidade, com seus respectivos termos, aparece no material de maneira associada à categoria quantidade. Em outras palavras, as nacionalidades são normalmente dispostas em cada subcorpus tendo em vista o número de refugiados pertencentes a cada uma delas. As principais 
nacionalidades encontradas foram: palestinos, sírios, venezuelanos e "africanos". Abaixo estão alguns exemplos das linhas de concordância analisadas nesta categoria:

\begin{tabular}{|l|c|l|}
\hline $\begin{array}{l}\text { Num sistema de quotas para } \\
\text { realocar } \mathbf{1 2 0} \text { mil }\end{array}$ & refugiados & sírios. \\
\hline Um quarto de todos os & refugiados & são palestinos, por exemplo. \\
\hline Hoje, há 3,9 milhões de sírios & refugiados & em 107 países. \\
\hline $\begin{array}{l}\text { A União Europeia prometeu } \\
\text { abrigar } \mathbf{8 0 0} \text { mil }\end{array}$ & refugiados & em 2015, a maioria sírios. \\
\hline
\end{tabular}

Quantidade. A categoria quantidade, bem como seus respectivos termos, apresenta um padrão de referência às categorias de nacionalidade, local e movimento, especificando de qual país ou local é o refugiado e para onde este sujeito vai (aonde ele chega, aporta, entra). Quanto aos locais, foram encontrados padrões de referência à Europa. Já quanto ao movimento, o padrão de referência aponta para a proibição e/ou permissão da mobilidade dos sujeitos refugiados. Alguns exemplos das linhas de concordância da categoria são:

\begin{tabular}{|l|c|l|}
\hline Desde 2012, mais $\mathbf{2 0 0}$ mil & refugiados & $\begin{array}{l}\text { chegaram, segundo o } \\
\text { ACNUR. }\end{array}$ \\
\hline O Brasil tem cerca de 10 mil & refugiados & de 82 nacionalidades. \\
\hline $\begin{array}{l}\text { Nos últimos meses, milhares } \\
\text { de }\end{array}$ & refugiados & $\begin{array}{l}\text { chegaram à Europa, vindos } \\
\text { da África }\end{array}$ \\
\hline $\begin{array}{l}\text { Teria permitido a entrada de } \\
\mathbf{2 4} \text { mil }\end{array}$ & refugiados & $\begin{array}{l}\text { adicionais nos Estados } \\
\text { Unidos. }\end{array}$ \\
\hline
\end{tabular}

Local. A categoria local, e seus respectivos termos, apresenta padrões de referência às expressões "campo de refugiados" e "centro de refugiados". Foram encontradas referências principalmente à localização desses campos e centros, bem como à vida em tais locais, com relatos de episódios de violência. Também foram encontrados padrões de referência a "centros de detenção" e "campos de detenção" para sujeitos refugiados. Exemplos das linhas de concordância da categoria podem ser lidos abaixo: 


\begin{tabular}{|l|c|l|}
\hline $\begin{array}{l}\text { Bangladesh quer criar um } \\
\text { campo de }\end{array}$ & refugiados & Com população igual a de \\
\hline Ressurge como abrigo para & refugiados & Em Berlim. \\
\hline Polícia retira & refugiados & À força de campo. \\
\hline $\begin{array}{l}\text { Contra a instalação de um } \\
\text { centro de }\end{array}$ & refugiados & Perto de suas casas. \\
\hline
\end{tabular}

Cuidado. A categoria cuidado, e seus respectivos termos, aparece no material fazendo referência freqüente à categoria quantidade, a doações para "cuidar" dos sujeitos refugiados, às instituições encarregadas do cuidado, bem como à ajuda com questões de abrigo e burocracia. Alguns exemplos das linhas de concordância da categoria estão expostos abaixo:

\begin{tabular}{|l|l|l|}
\hline $\begin{array}{l}\text { Voluntários que, a cada dia, } \\
\text { ajudam os }\end{array}$ & Refugiados & $\begin{array}{l}\text { A enfrentarem a burocracia } \\
\text { do país }\end{array}$ \\
\hline $\begin{array}{l}\text { O país poderia acolher cerca } \\
\text { de } \mathbf{1 0 0} \text { mil }\end{array}$ & Refugiados & Nos próximos cinco anos. \\
\hline $\begin{array}{l}\text { Autoridades européias } \\
\text { aceitaram acolher } \mathbf{1 2 0} \text { mil }\end{array}$ & Refugiados & $\begin{array}{l}\text { Embora a decisão enfrente a } \\
\text { resistência de alguns. }\end{array}$ \\
\hline O Brasil acolhe cerca de $\mathbf{4}$ mil & Refugiados & $\begin{array}{l}\text { Embora relativamente baixo, o } \\
\text { problema merece }\end{array}$ \\
\hline
\end{tabular}

Crise. A categoria crise foi a única, dentre as outras seis (6) categorias, que não apresentou termos similares a serem trabalhados pela análise do material. Foi observado um padrão de referência à expressão "a pior crise de refugiados desde a segunda guerra mundial". Além disso, a análise demonstra que a crise é apresentada como um problema fundamentalmente europeu que deve ser resolvido, uma vez que afeta a economia dos países. Seguem abaixo alguns exemplos da utilização dessa categoria no corpus: 


\begin{tabular}{|l|c|l|}
\hline $\begin{array}{l}\text { Não há soluções fáceis para a } \\
\text { crise de }\end{array}$ & refugiados & $\begin{array}{l}\text { Da Europa. Num mundo de } \\
\text { Estados frágeis }\end{array}$ \\
\hline $\begin{array}{l}\text { No qual enfrentamos a maior } \\
\text { crise de }\end{array}$ & refugiados & $\begin{array}{l}\text { Desde a Segunda Guerra } \\
\text { Mundial. }\end{array}$ \\
\hline $\begin{array}{l}\text { A crise migratória na Europa } \\
\text { de }\end{array}$ & refugiados & $\begin{array}{l}\text { Vindos do Oriente Médio e da } \\
\text { África }\end{array}$ \\
\hline $\begin{array}{l}\text { Avaliará custo econômico da } \\
\text { crise de }\end{array}$ & refugiados & $\begin{array}{l}\text { Os ministros de economia da } \\
\text { União }\end{array}$ \\
\hline
\end{tabular}

Movimento. A categoria movimento, com seus respectivos termos, apresenta padrões que indicam referência às categorias quantidade, local e nacionalidade. Também foram observados padrões de associação com termos que indicam controle do movimento (permitir ou proibir a mobilidade dos refugiados), bem como a relação entre o movimento desses sujeitos e o aumento populacional dos países que os recebem. Alguns exemplos do emprego desta categoria temática podem ser lidos abaixo:

\begin{tabular}{|l|c|l|}
\hline $\begin{array}{l}\text { Se preparam para uma nova } \\
\text { onda de }\end{array}$ & refugiados & $\begin{array}{l}\text { Sírios. Os grupos de ajuda } \\
\text { sabem que }\end{array}$ \\
\hline $\begin{array}{l}\text { É um ponto importante de } \\
\text { saída de }\end{array}$ & refugiados & $\begin{array}{l}\text { Da África que tentam } \\
\text { alcançar a Europa }\end{array}$ \\
\hline $\begin{array}{l}\text { Anunciaram medidas de } \\
\text { controle na entrada de }\end{array}$ & $\begin{array}{l}\text { Antes mesmo, Merkel já } \\
\text { anunciara }\end{array}$ \\
\hline Da onda de & refugiados & Que inunda a Europa. \\
\hline
\end{tabular}

Status. A categoria status, e seus termos, indica preocupações com a regularização dos sujeitos refugiados, isto é, com a aplicação do estatuto do refúgio. Foram observadas tentativas de definição do refugiado, com sua diferenciação do imigrante, assim como sua articulação com as categorias quantidade e nacionalidade. Seguem alguns exemplos das linhas de concordância da categoria: 


\begin{tabular}{|l|l|l|}
\hline $\begin{array}{l}\text { O ACNUR declarou que } \\
\text { reconhecia como }\end{array}$ & Refugiado & $\begin{array}{l}\text { Toda pessoa que esteja } \\
\text { fugindo do }\end{array}$ \\
\hline $\begin{array}{l}\text { Pessoas de 82 nacionalidades } \\
\text { foram reconhecidas como }\end{array}$ & Refugiadas & $\begin{array}{l}\text { :apenas em 2016, mais de 3 } \\
\mathbf{3 0 0}\end{array}$ \\
\hline $\begin{array}{l}\text { Segundo a Cáritas, 171 sírios } \\
\text { foram reconhecidos como }\end{array}$ & Refugiados & Em São Paulo ao longo do \\
\hline O reconhecimento como & Refugiado & Garante proteção sob as leis \\
\hline
\end{tabular}

A análise qualitativa das linhas de concordância do termo de busca também foi complementada pela análise quantitativa das frequiências das categorias. Esta análise foi realizada em cada subcorpus da pesquisa, considerando como valores de referência a quantidade de termos categorizados no material. Embora se tenha optado pela análise individual, de cada subcorpus, a fim de verificar a disposição dos dados, após a interpretação do material verificou-se a pouca variação na distribuição das categorias pelo material. Dessa maneira, estará exposta aqui, na figura 1, apenas a distribuição das categorias no corpus total da pesquisa.

Apesar da opção por expor apenas uma figura (ao invés de seis) com os dados gerais da distribuição das categorias no corpus, considero relevante ressaltar aqui algumas informações da análise individual: de todos os subcorpus, apenas IstoÉ e ElPaís apresentaram a categoria nacionalidade mais freqüente do que a categoria quantidade; a terceira categoria mais freqüente em cada subcorpus é local, seguida por cuidado, movimento, crise e status; a categoria "status", apesar de ser a menos freqüente em cada subcorpus, apresentou frequiência maior (dois pontos percentuais) nos subcorpus Uol, Globo e Gazeta. Tendo isso em mente, segue abaixo a figura 1 com a distribuição das categorias pelo corpus total da pesquisa: 
Figura 1: Distribuição das Categorias no corpus

\section{Categorias}

Quantidade $\square$ Nacionalidade $\square$ Local $\square$ Cuidado $\square$ Movimento $\square$ Crise $\square$ Status

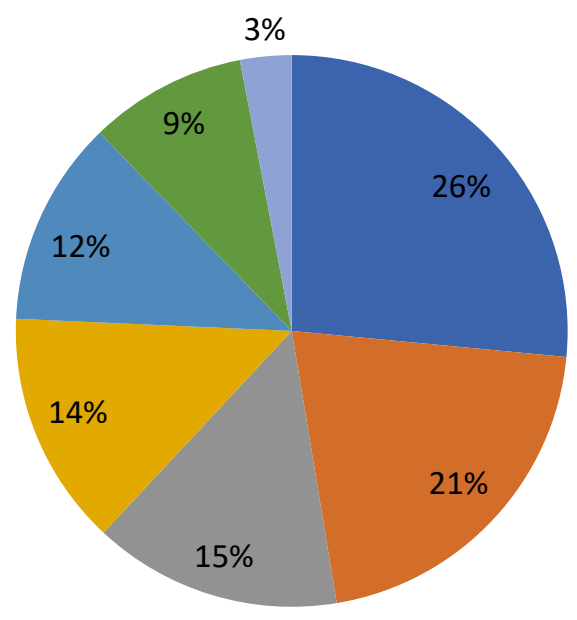

O gráfico exposto acima segue o padrão de distribuição das categorias pelos subcorpus analisados, o que só pôde ser constatado após a análise individual de cada subcorpus. Temos, assim, a manutenção de um padrão de representação do refugiado que envolve preocupações com a quantificação desses sujeitos, com suas nacionalidades e locais onde vivem e para onde migram, seguido de referências ao cuidado despendido em relação aos mesmos, bem como ao seu movimento (articulado a noções de controle e gerenciamento) e à crise que representa tal mobilidade. Por último, mas ainda de forma significativa o suficiente para emergir como categoria analítica no material, temos padrões de menção ao status das pessoas que migram, diferenciando refugiados de migrantes.

Além da análise léxica direcionada à interpretação dos dados acerca do vocabulário que acompanha, de maneira freqüente, as representações do refugiado, a pesquisa também buscou realizar uma análise dos verbos dos quais o refugiado é sujeito e objeto a fim de refletir sobre a agência gramatical. Assim como o processo de categorização, a análise gramatical foi realizada a partir da observância detalhada e manual das linhas de concordância em cada subcorpus da pesquisa, sendo 
possível, então, observar os verbos mais freqüentes relacionados ao termo de busca (refugiad*). Porém, mais do que uma preocupação com a disposição de freqüências, o interesse aqui é analisar o contexto de cada utilização gramatical para observar como os verbos foram empregados. A tabela 5 abaixo apresenta os verbos mais freqüentes dos quais o refugiado é apresentado como sujeito:

Tabela 6: Verbos dos quais o refugiado é sujeito

\begin{tabular}{ll}
\hline Subcorpus & Verbos \\
\hline Uol & Ser; Estar; Viver; Chegar; Tentar; Atravessar; \\
& Poder; Entrar. \\
& \\
Globo & Ser; Estar; Enfrentar; Entrar; Contribuir; \\
& Cruzar; Chegar; Buscar.
\end{tabular}

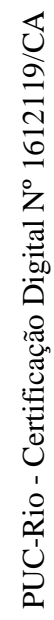

Abril
Gazeta

IstoÉ

ElPaís
Ser; Estar; Cruzar; Fugir; Escapar; Caminhar; Atravessar; Chegar.

Ser; Estar; Escapar; Arriscar; Atravessar; Caminhar; Buscar; Chegar.

Ser; Estar; Chegar; Buscar; Conseguir; Tentar; Cruzar; Entrar.

Ser; Estar; Buscar; Caminhar; Chegar; Atravessar; Cruzar; Viver. 
Os verbos "ser e estar" são os mais freqüentes da língua portuguesa e aparecem, portanto, como mais freqüentes em cada um dos subcorpus da pesquisa. A análise do contexto de cada linha de concordância aponta para a utilização freqüente do verbo "ser" em referência a: "ser autorizado"; "ser bem-vindo" e "ser ameaça". Além disso, este verbo também é freqüentemente empregado em tentativas de definição do sujeito refugiado (diferenciando-o do imigrante econômico) e indicação de sua nacionalidade. Quanto à análise do emprego do verbo "estar", temos a utilização freqüente em referência a: "estar em campos", "estar indefeso" e "estar sujeito a". Este verbo também é freqüentemente utilizado para fazer referência aos lugares onde os refugiados se encontram. Os outros verbos dos quais o refugiado aparece como sujeito apontam, em grande medida, para a categoria movimento (atravessar, entrar, cruzar, chegar, etc). Os verbos "viver" e "chegar" são normalmente utilizados para indicar a localização dos sujeitos (onde vivem e aonde chegam). O verbo "poder" foi empregado em expressões como: "podem contribuir"; "podem ampliar mão-de-obra"; "podem procurar abrigo".

Durante a análise manual das linhas de concordância em busca de padrões de emprego dos verbos, chamou atenção a baixa ocorrência dos verbos "dizer" e "afirmar" para relatar discursos e narrativas. Dessa maneira, diferentemente da análise empregada nos outros casos, busquei de forma direta as concordâncias e frequiências desses dois verbos, levando em consideração seus contextos. A tabela 6 indica a frequiência em que ambos os verbos são empregados para fazer referência a algo dito pelo refugiado e a algo dito por outro sujeito (normalmente instituições internacionais e não-governamentais) sobre o refugiado. Em outras palavras, a tabela abaixo expõe a freqüência do refugiado enquanto sujeito do discurso direto e do refugiado enquanto objeto do discurso alheio. 
Tabela 7: Frequiência por sujeito do discurso

\begin{tabular}{|c|c|c|}
\hline Subcorpus & Sujeito Refugiado & Sujeito "Outro" \\
\hline Uol & 9 & 33 \\
\hline Globo & 1 & 20 \\
\hline Abril & 0 & 31 \\
\hline Gazeta & 4 & 30 \\
\hline IstoÉ & 2 & 18 \\
\hline ElPaís & 2 & 25 \\
\hline Total & 18 & 157 \\
\hline
\end{tabular}

A tabela 6 indica, assim, que apesar de poucas referências ao discurso direto nos textos dos jornais e portais analisados, aqueles que dizem ou afirmam algo sobre os refugiados de maneira freqüente não são os próprios sujeitos em condição de refúgio, mas agentes de organizações internacionais (como o ACNUR) e de instituições da sociedade civil, como a Cáritas (no caso brasileiro), bem como políticos, funcionários de agências governamentais e os chamados especialistas no assunto. De maneira geral, então, dos 175 discursos diretos apresentados no corpus da pesquisa, apenas 18 deles são narrativas dos refugiados, enquanto a maioria é composta por falas de outros atores sobre a condição refugiada. 
No que diz respeito às construções verbais nas quais o refugiado é apresentado como objeto dos verbos, a análise manual e detalhada das linhas de concordância, em seus devidos contextos, fez emergir a categoria "cuidado". Além disso, foi possível criar uma nova categoria a partir da interpretação das concordâncias gramaticais - a categoria "controle", indicando verbos relacionados à permissão e à proibição (admitir, recusar, conter, impedir, etc). Assim como no processo de categorização envolto na análise léxica, tais categorias emergiram da análise qualitativa das concordâncias mais freqüentes e de seu significado no contexto mais amplo de cada texto. Também procurei realizar novamente uma análise individual, considerando separadamente cada subcorpus da pesquisa. A tabela 7 traz os verbos mais freqüentes dos quais o refugiado é apresentado como objeto.

Tabela 8: Verbos dos quais o refugiado é objeto

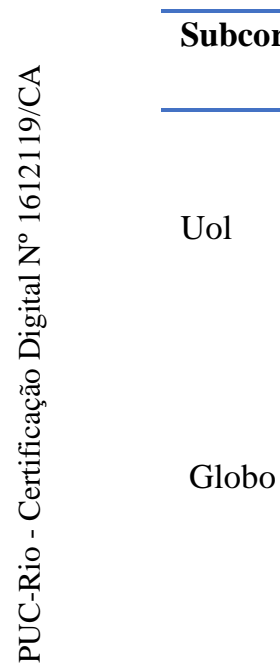

Verbos

Abril Proteger; acolher; ajudar; abrigar; receber; resgatar; aceitar; conter.

Gazeta Proteger; acolher; ajudar; abrigar; conter; receber; recusar; proibir; barrar; reter; deter.

IstoÉ Proteger; acolher; ajudar; abrigar; receber; aceitar; apoiar; admitir; contratar; identificar. 
A tabela 7 demonstra, assim, os principais verbos dos quais o refugiado aparece como objeto. A categoria “cuidado" pode ser vista pela utilização de verbos como proteger, acolher, ajudar e abrigar. Já a categoria "controle" pode ser vista a partir dos seguintes verbos: conter, recusar, receber, proibir, barrar, reter, deter, devolver, aceitar e impedir. Alguns verbos como transferir, distribuir e redistribuir aparecem com frequiência no subcorpus ElPaís e poderiam ser também incluídos na categoria "controle", se não pela referência à idéia de permissão ou proibição, pela referência ao gerenciamento dos sujeitos e seus corpos, realocados a partir de práticas que poderíamos identificar com o sentido de controle.

Considerando que a categoria "controle" não havia surgido anteriormente na análise léxica de cada subcorpus da pesquisa, mas apenas nessa etapa de interpretação do viés gramatical nas linhas de concordância, torna-se relevante expor aqui maiores informações sobre esta categoria e a atualização da tabela e do gráfico correspondentes. Assim, a tabela 8 abaixo traz os termos associados à nova categoria:

Tabela 9: Categorias e Termos Associados - inclusão da categoria "controle"

Categorias Termos

Quantidade

Nacionalidade

Local
Número; Mil; Milhões; Milhares.

sírios; venezuelanos; palestinos; africanos;

afegãos; iraquianos; angolanos.

Campo; centro; abrigo; região. 
Cuidado

Crise

Movimento

Status

Controle

Controle. A categoria controle é constantemente empregada, em cada subcorpus da pesquisa, para fazer referência aos governos que aceitam ou barram refugiados, às cotas estabelecidas para recebimento e redistribuição desses sujeitos entre países, à quantidade de refugiados retidos, devolvidos, aceitos, recebidos, e assim por diante. De maneira geral, então, temos o emprego dos verbos associados à nova categoria criada a fim de expor a política dos países a respeito do gerenciamento dos fluxos de refugiados. Abaixo estão alguns exemplos das linhas de concordância analisadas nesta categoria:
Abrigar; acolher; assistir; ajudar; acomodar; proteger; amparar.

Crise - não foram encontrados termos similares.

Fluxo; entrada; onda; fuga; saída; entrar; sair; cruzar; cruzamento; travessia; atravessar.

Visto como; reconhecido como; tratado como; aceito como; considerado como; definido como; registrado como; status como.

Conter; recusar; receber; proibir; barrar; reter; deter; devolver; aceitar; impedir; transferir; distribuir e redistribuir. 


\begin{tabular}{|l|c|l|}
\hline O país não aceita nenhum & refugiado & $\begin{array}{l}\text { Que chegue pelo mar em seu } \\
\text { território. }\end{array}$ \\
\hline Após acordo, 600 mil & refugiados & Podem ser devolvidos a \\
\hline Policiais tentam conter & refugiados & $\begin{array}{l}\text { Que procuram embarcar na } \\
\text { estação }\end{array}$ \\
\hline E pretende redistribuir 160 mil & refugiados & Em toda a União Europeia \\
\hline
\end{tabular}

Tendo considerado o emprego da categoria "controle" em cada subcorpus, bem como a nova tabela com os termos associados, a figura 2 abaixo traz a distribuição atualizada das categorias no corpus geral da pesquisa:

Figura 2: Distribuição das categorias no corpus - inclusão da categoria "controle"

\section{Categorias}

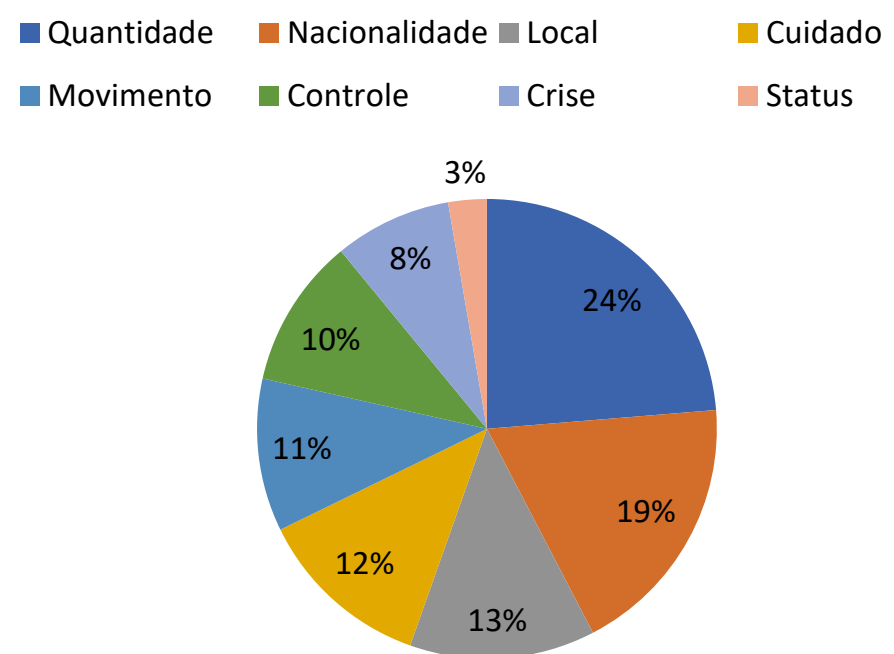

O gráfico atualizado da distribuição das categorias pelo corpus da pesquisa demonstra, assim, que a categoria "movimento" encontra-se entre "cuidado" e "controle". A distribuição do restante das categorias encontra-se, em grande medida, preservada, com alterações pequenas nos percentuais de cada uma das categorias analíticas, embora com relevância importante em termos da freqüência da categoria "controle".

As páginas anteriores buscaram apresentar, de maneira didática, os resultados obtidos pela análise léxica e gramatical de cada um dos subcorpus da 
pesquisa. Ainda que eu tenha empreendido o esforço de comentar os dados e informações expostas anteriormente, considero relevante dedicar a última seção do capítulo a análises mais coesas, e menos atravessadas por tabelas, sobre o que chamo aqui de "campo semântico do refúgio". Buscarei apresentar, a partir disso, reflexões sobre os espaços de habitação possível na mídia para os sujeitos que se encontram na condição refugiada e como isso pode reverberar formas de injustiça hermenêutica. Discuto, assim, a pluralidade de significados produzidos pela grande mídia brasileira sobre a figura do refugiado, a possível existência de dificuldades no que diz respeito à inteligibilidade desta experiência social e a ausência de um espaço comum de troca sobre a experiência do refúgio a partir da própria condição refugiada. Para tanto, retomarei não somente os resultados léxicos e gramaticais detalhados nesta seção, como também os debates teóricos que atravessam toda a tese e funcionam como fio condutor da análise.

\section{5 O campo semântico do refúgio no Brasil e a injustiça hermenêutica}

Apesar dos resultados da análise léxica e gramatical terem sido comentados de maneira detalhada na seção anterior, considero importante tecer algumas breves reflexões a partir dos dados, de forma a elaborar uma interpretação mais coesa sobre o que chamo aqui de campo semântico do refúgio no Brasil e a possibilidade de manifestação de uma injustiça hermenêutica. Não busco esgotar todas as possibilidades de análise a partir da pesquisa realizada, mas enfatizo aqui três aspectos mais gerais que emergem como relevantes nesse cenário: primeiro, o refúgio em números como uma questão importante dentro de um quadro de representação dos sujeitos refugiados; segundo, o vínculo nacional, ou a questão da nacionalidade, como fator essencial de referência à condição refugiada; e, terceiro, a categoria do "movimento" entre o "cuidado" e o "controle", que faz emergir discussões teóricas já existentes sobre os espaços reservados ao refugiado.

A partir dos aspectos supracitados, procuro discutir algumas questões relevantes na análise sobre a produção de uma injustiça epistêmica, como o empobrecimento e a marginalização hermenêutica, o imaginário social e os estereótipos e preconceitos na interpretação das experiências de determinados sujeitos. Podemos ver, assim, que a desapropriação das narrativas e o 
desaparecimento do refugiado no processo de elegibilidade, analisado nos capítulos anteriores, acaba sendo reproduzido nas práticas de representação midiática da experiência do refúgio, contribuindo para a produção de uma injustiça epistêmica de caráter hermenêutico.

O processo de categorização empreendido aqui chamou a atenção para o fato de que a categoria "quantidade" é a que mais atravessa ou perpassa outras categorias produzidas durante a análise com corpus. Seja em relação à nacionalidade, à crise, ao movimento, ao local, os padrões de representação encontrados envolvem a busca pela exposição dos números de refugiados. Assim, grande parte das referências aos refugiados é acompanhada pela tentativa de quantificação desses sujeitos, ajudando a sustentar a idéia de crise normalmente atrelada à perspectiva dos grandes fluxos de pessoas (e que também emergiu como uma categoria analítica na pesquisa). A ideia de uma crise de grandes proporções, devido ao elevado número de sujeitos em busca de refúgio, também é sustentada por uma alta freqüência de alguns termos na categoria "movimento" que adquirem sentido negativo, como onda e fluxo. Conforme afirmam Strom e Alcock (2017), essa terminologia ajuda a criar representações dos imigrantes como desastres naturais, o que faz com que políticas migratórias possam ser formuladas de maneira desumana. Assim, na perspectiva das autoras, ao invés de enfatizar a violência sofrida no país de origem ou a necessidade de assistência, tal vocabulário acaba por representar os imigrantes como desastres que podem causar sérios estragos e, portanto, precisam ser controlados ou gerenciados.

A fixação por números para representar o fluxo de refugiados (e imigrantes de maneira geral) pode ser vista, assim, como uma forma de tratar a mobilidade como algo caótico e fora do controle (Strom e Alcock, 2017) e, portanto, como uma crise a ser gerenciada. Ao mesmo tempo, a análise léxica da categoria "crise" traz referências freqüentes ao contexto europeu, invocando a percepção de uma crise européia de refugiados, o que parece desconsiderar os próprios números em contexto. Em outras palavras, podemos dizer que a quantificação é usada de maneira descontextualizada, ao trazer a idéia freqüente de uma crise européia de refugiados, enquanto os dados apontam para os países menos desenvolvidos como destino de grande parte dos fluxos. Conforme exposto no relatório do ACNUR (2017), 85\% dos refugiados estão nos países em desenvolvimento, com quatro em cada cinco refugiados permanecendo em países próximos aos seus locais de origem. 
Ainda de acordo com o relatório, 63\% de todas as pessoas refugiadas sob a responsabilidade do ACNUR estão em apenas dez países, como Turquia e Líbano. Temos, nesse cenário, não só uma distribuição desigual do ônus da recepção e do acolhimento dos refugiados, mas também dos custos de arcar com os conflitos que motivam os deslocamentos forçados, que recaem igualmente sobre os países mais pobres.

Se o refúgio em números parece ser uma preocupação, conforme podemos ver a partir das análises, não é possível afirmar o mesmo sobre o uso dos dados de maneira contextualizada a fim de não produzir um quadro representativo com potencialidade de distorcer o cenário. Não procuro argumentar aqui a inexistência de um contexto preocupante com o deslocamento forçado em massa, nem tampouco busco negar as mortes constantes nas travessias rumo à Europa, mas esboço uma tentativa de refletir sobre o modo como a mobilidade humana passa a ser representada. Conforme nos diz Facundo, o que nos é oferecido com os dados acerca do refúgio, a quantificação constante e insistente das populações que migram, não é o retrato de uma dada realidade apenas, mas sim "um discurso que constrói uma visão política específica sobre os êxodos, as apátridas, os deslocamentos e as pessoas que atravessam a terra e as fronteiras" (Facundo, 2017, p.43). Tal narrativa produzida pode, assim, reforçar a própria idéia da necessidade do controle e do gerenciamento dos fluxos, ao trazer de maneira contundente tipos de representação que enfatizam "a maior crise de refugiados desde a Segunda Guerra Mundial”. Teríamos, assim, não só uma emergência humanitária, mas um campo passível de intervenção.

A representação midiática dos refugiados a partir da categoria da "quantidade" traz, assim, algumas imagens associadas ao caos, aos desastres e às crises, fazendo referência aos impactos negativos dos grandes fluxos de pessoas sobre os países de acolhida. Poderíamos dizer, assim como Fricker (2007), que há uma espécie de empobrecimento hermenêutico coletivo que, neste caso em específico, afeta os sujeitos que pertencem ao grupo dos refugiados representado pela grande mídia brasileira. Ainda que o processo de elegibilidade dependa, em grande medida, de uma análise individual das histórias de perseguição, ao serem representados na mídia, os refugiados passam a ser vistos de maneira homogeneizada, com a produção de um gap na inteligibilidade da experiência social particular que motivou o deslocamento. Esse tipo de lacuna hermenêutica 
afeta, assim, a possibilidade de compreensão do cenário complexo que constitui o refúgio em nome de uma simplificação numérica que evidencia possíveis impactos sobre países que recebem refugiados, obscurecendo, por exemplo, os contextos políticos e sociais que produzem deslocamentos forçados. Conforme nos diz Fricker, em um quadro de empobrecimento hermenêutico uma situação concreta não pode ser comunicada de maneira inteligível. Nesse sentido, aqueles aspectos fundamentais de uma experiência social, que os sujeitos teriam interesse em tornar inteligível, acabam não sendo coletivamente compreendidos, contribuindo para a produção de uma injustiça hermenêutica.

Neste contexto da representação do refúgio em números, ganha relevância também o papel do chamado imaginário social. Segundo Medina (2011), a noção de imaginário social pode ser compreendida como um repositório de imagens que se tornam coletivamente compartilhadas e impactam na produção de uma ignorância ativa, isto é, a ignorância que tem por base uma série de distorções sistemáticas. $\mathrm{O}$ autor afirma, assim, que o imaginário social produz uma forma de preguiça epistêmica que bloqueia possíveis explorações de evidências, o que se torna, por sua vez, um obstáculo epistêmico na busca por conhecimento, podendo levar a injustiças epistêmicas. O imaginário social também acaba produzindo uma forte resistência a adotar novos pontos de vista, impedindo que diferentes perspectivas sobre um mesmo tema sejam levadas seriamente em consideração. Conforme nos diz Medina, tal imaginário pode tornar algumas experiências altamente visíveis ao mesmo tempo em que ele também pode tornar outras altamente implausíveis ou até ininteligíveis, o que revela seu caráter hermenêutico, uma vez que afeta a capacidade das pessoas no que diz respeito à interpretação e à compreensão das experiências.

O quadro de representação do refúgio em números, que apela para imagens distorcidas sobre o fluxo de pessoas enquanto uma espécie de desastre natural ou estado caótico de crise em determinados países de acolhida (especialmente europeus), pode acabar produzindo um determinado imaginário social a respeito da condição refugiada. Neste contexto, os sujeitos refugiados acabam marginalizados hermeneuticamente, localizados em uma posição de desvantagem que faz com que suas experiências sociais não sejam bem compreendidas. Nos termos propostos por Medina (2011), poderia haver a produção de uma injustiça hermenêutica resultante dos obstáculos e limitações do imaginário social a respeito do refúgio, gerando a 
incapacidade de compreender certas experiências ou fenômenos. Em outras palavras, "formas sociais de cegueira e surdez que limitam as capacidades comunicativas e epistêmicas de membros de certos grupos e impedem uma compreensão genuína de suas experiências, problemas e situações" (idem, p.27).

O campo semântico do refúgio no Brasil, com a produção de uma série de significados pela mídia, abarca não somente a perspectiva do refúgio em números, que pode autorizar práticas de gerenciamento e regulação de um conjunto de sujeitos (Facundo, 2017), como também envolve a articulação entre a idéia de quantidade e de nacionalidade. Conforme visto através da análise com corpus, a categoria "nacionalidade" emerge de maneira largamente associada à categoria "quantidade", com a constante representação do número dos refugiados em relação a algumas nacionalidades específicas, como palestinos, sírios, venezuelanos e "africanos". A partir disso, foi possível notar que, ao invés de uma referência às histórias individuais de perseguição, temos uma representação midiática de um corpo homogêneo de nacionalidades, em que, no limite do processo de homogeneização, o continente africano é tratado como uma só nacionalidade. Assim, apesar do lugar-chave que a narrativa individual de perseguição ocupa nos procedimentos burocráticos de determinação da condição refugiada, bem como nas normativas sobre a concessão do status, vemos que na representação midiática o caráter individual do refúgio perde espaço para a formação de um corpo homogêneo de refugiados.

Considero aqui a importância de discutir brevemente a questão da nacionalidade pelo duplo papel que desempenha no universo institucional do refúgio. A expressão-chave da definição oficial da condição refugiada envolve o chamado "fundado temor de perseguição", que abarca dimensões subjetivas e objetivas. Em outras palavras, o solicitante de refúgio precisa demonstrar, de maneira individual, que possui um temor de perseguição e, ao mesmo tempo, tal temor precisa ser fundado, uma vez que deve encontrar apoio na situação objetiva em seu país de origem. Conforme vemos nos manuais de determinação de status produzidos pelo ACNUR, o "estado de espírito" do solicitante de refúgio precisa ser baseado em uma situação objetiva, o que significa que, para determinar a existência de um fundado temor, é preciso levar em consideração ambos os elementos objetivos e subjetivos. Nesse sentido, o temor somente é visto como fundado se o solicitante consegue demonstrar, de modo razoável, que seu retorno 
ao país de origem se tornou intolerável por algum dos motivos que constam na definição do estatuto do refugiado, ainda que não fique claro o que pode ser considerado "razoável" na necessária demonstração de medo por parte do refugiado. Temos, assim, a dimensão individual da narrativa do solicitante de refúgio como parte fundamental no processo de determinação da sua condição refugiada, ainda que sua nacionalidade seja relevante a fim de contextualizar o relato e analisar seu mérito a partir de uma situação política e social supostamente objetiva em dado país.

Por outro lado, a nacionalidade também emerge como crucial na determinação do status de refugiado por trazer à tona certos estereótipos que acabam por fazer parte dos procedimentos burocráticos deste universo. A partir de algumas análises teóricas já realizadas no tema, podemos refletir sobre traços físicos e comportamentais que são atribuídos a certos grupos nacionais de refugiados, por exemplo. Isso produz não somente a expectativa de como certo "tipo" de solicitante de determinada nacionalidade costuma se comportar, mas também de como ela deve apresentar algumas características natas que a fazem, por exemplo, dramatizar ao extremo a sua narrativa, gerando um sentimento de descrença por parte do responsável por analisar sua solicitação de refúgio (Jubany, 2011, 2017). Assim, apesar da importância das histórias individuais de perseguição, temos também o caráter central da nacionalidade, em um processo que, conforme nos diz Jubany, acaba por conferir legitimidade a certas narrativas de acordo com cada grupo nacional, com quais tipos de pessoas de certos países irão solicitar refúgio e com quais tipos de histórias trarão consigo.

A análise com corpus realizada aqui aponta para um alinhamento da representação midiática dos sujeitos refugiados com a tendência de produção de estereótipos mencionada no parágrafo anterior, que também faz parte dos procedimentos burocráticos de determinação do status, conforme vimos no segundo capítulo. Assim, ao invés de menções a histórias individuais de perseguição ou a situações políticas de opressão e violência que geram o deslocamento de populações, temos padrões de representação numérica de refugiados por nacionalidade. Tal tendência a homogeneizar os sujeitos em busca de refúgio e de tratá-los como uma massa de corpos sem rostos também pode ser constatada pelo pouco espaço que sua própria voz ocupa na mídia. Conforme demonstrado pela análise gramatical dos verbos dizer e afirmar, das 157 ocorrências de discurso direto 
nos textos, apenas 18 se referiam a algo dito pelo próprio refugiado sobre sua situação. Podemos refletir, assim, que os sujeitos autorizados a falar sobre o refúgio são normalmente aqueles que nunca passaram pela experiência de estar refugiado. Temos, então, conforme afirma Fassin (2007), a “vida biográfica”, vivida por um sujeito, mas narrada por outro.

A marginalização dos sujeitos refugiados na produção de significados emerge como um ponto importante na discussão sobre injustiça hermenêutica. Conforme nos lembra Alcoff (2010), a marginalização hermenêutica é distinta de uma injustiça testemunhal, uma vez que está relacionada à impossibilidade de participação de um sujeito na construção de significados, o que pode levar a uma incapacidade interpretativa em relação às suas experiências sociais. Tanto Fricker (2007) quanto Alcoff (2010) afirmam que a marginalização de sujeitos no processo de construção de significados e conceitos pode produzir um gap hermenêutico de inteligibilidade, o que pode ter implicações em termos de conteúdo (conceitos disponíveis para refletir sobre uma determinada experiência) e estilo (as formas pelas quais a comunicação de uma experiência acontece). A quase completa ausência das falas dos refugiados nos textos midiáticos pode evidenciar, assim, uma participação desigual na produção de significados e conceitos acerca da experiência do refúgio, o que possui impactos hermenêuticos no campo da inteligibilidade da condição refugiada. A participação desses sujeitos na mídia, através de relatos e perspectivas diversas que teriam a contribuir na discussão sobre refúgio, poderia gerar, assim, um campo distinto de significados e conceitos, para além das noções numéricas, nacionais, de cuidado e de controle que a análise com corpus evidenciou.

Como vimos no capítulo teórico, a injustiça hermenêutica é sempre estrutural e ocorre quando uma sociedade não possui os recursos interpretativos para fazer sentido de aspectos importantes da experiência vivida por determinados sujeitos, os quais se encontram marginalizados nas atividades de produção de significados (Fricker, 2007). Um dos exemplos levantados por Fricker nesse contexto diz respeito à ininteligibilidade da experiência do assédio sexual que mulheres sofriam antes da introdução deste conceito no discurso público. As mulheres assediadas sexualmente sofriam uma injustiça hermenêutica, uma vez que não possuíam os recursos interpretativos para fazer sentido da experiência violenta, comunicá-la a outros e, assim, terem a compreensão e o reconhecimento daquilo 
que vivenciaram. A injustiça sofrida se deve, então, a uma marginalização epistêmica preconceituosa: nós, mulheres, não éramos levadas a sério como narradoras de experiências injustas sofridas (Anderson, 2012). Da mesma forma, é preciso questionar a ausência da participação de refugiados na produção de significados sobre a sua própria condição sócio-política e em que medida essa marginalização se deve a preconceitos acerca das suas capacidades enquanto sujeitos adequados para narrar experiências relevantes no campo do deslocamento forçado e da mobilidade em um regime de Estados.

Este quadro de representação delineado a partir da análise com corpus evidencia não somente uma desigualdade radical entre os sujeitos na produção de significados sobre a condição refugiada, mas também a existência de estereótipos no sentido proposto por Bhabha (1988), isto é, o desejo impossível de uma origem pura e homogênea. Dessa maneira, a referência constante aos números de refugiados por nacionalidade acaba por apagar o caráter individual e único dos sujeitos, reproduzindo-os de forma homogênea e limitando a alteridade a uma forma fixa de tipo nacional. Não é surpreendente, assim, que as experiências sociais desses sujeitos acabam sendo apresentadas de maneira preconceituosa ou errônea, uma vez que, como vimos, os refugiados acabam marginalizados e excluídos dos processos de produção de significados. Nesse contexto, é possível afirmar a existência de uma lacuna hermenêutica que pode dificultar a inteligibilidade de circunstâncias e realidades diversas que não podem ser subsumidas a tipos nacionais, nem mesmo à representação midiática dos refugiados em termos de uma suposta característica homogênea derivada de sua condição enquanto "africanos". Do ponto de vista epistêmico, os recursos hermenêuticos coletivos se tornam estruturalmente preconceituosos, uma vez que as interpretações das experiências sociais de um grupo são tendenciosas por não serem influenciadas pelos membros de tal grupo, mas por sujeitos de grupos hermeneuticamente mais poderosos (Fricker, 2006).

Por fim, mas não menos importante, a análise com corpus realizada aqui também permitiu verificar a alocação da categoria "movimento" entre a categoria do "cuidado" e a categoria do "controle", em termos não só das freqüências observadas pela análise léxica, como também no que diz respeito à análise gramatical, com a inserção do refugiado na posição de objeto de verbos de controle e cuidado. Tal forma de representação dos sujeitos refugiados pela mídia encontra 
vastas discussões teóricas na literatura sobre o tema, que propõem o questionamento sobre o espaço reservado a tais sujeitos. A análise realizada pela pesquisa fez emergir, então, a necessidade do debate acerca do espaço do deslocamento como espaço pastoral, isto é, do cuidado caritativo e da política do afeto ou da piedade (Boltanski, 1999), com a inserção do refugiado em processos de vitimização que buscam apagar voz, face e agência (Soguk, 1999). Ao mesmo tempo, também é aberto caminho para refletir sobre os processos de marginalização que colocam o refugiado na posição de marginal, como figura que transgride a ordem nacional das coisas (Malkii, 1995) e, portanto, acaba sendo criminalizado. Teríamos, assim, o movimento dos sujeitos refugiados como algo não somente da ordem do cuidado humanitário, mas também com o caráter de ameaça emergencial que necessita ser controlada e gerenciada pelas políticas governamentais.

O sujeito refugiado é construído e representado, então, como esta figura paradoxal. Por um lado, o refugiado é objeto do cuidado e da ingerência das organizações não-governamentais, muitas delas de cunho religioso, que defendem a caridade e a piedade ao lidar com tal população. Por outro lado, o refugiado é tido também como objeto do controle e da intervenção dos poderes governamentais, que argumentam a necessidade da preservação das fronteiras soberanas do Estado, diante da ameaça daqueles que perderam o vínculo nacional que deveria lhes garantir proteção. Não é surpreendente, assim, que a análise tenha revelado a alocação do movimento entre o cuidado e o controle, o que não deixa de ser significativo como fundamento para pensar o campo semântico do refúgio no Brasil, que não se desfez das amarras dessa dupla imaginação (e prática) que recai sobre quem busca refúgio. Podemos ver, em tal contexto, a produção de uma imagem do refugiado que o coloca como objeto de compaixão e de pena ou como alguém indesejável que representa rupturas nas condições normais de vida (Soguk, 1999).

A análise com corpus demonstrou, assim, que o campo léxico e gramatical relacionado ao refugiado apresenta constantes referências à ajuda, a doações, ao acolhimento e abrigo, mas também é acompanhado por um campo, igualmente rico em termos gramaticais, que aponta para as idéias de distribuição, contenção, admissão e recusa. De acordo com a pesquisa, o refugiado é representado, então, duplamente como objeto - tanto do cuidado quanto do controle. Quando é visto como sujeito nos processos verbais, o refugiado está imbricado em ações 
indicativas de movimento - o mesmo movimento que é tratado pela lente da vitimização e da securitização. O campo semântico do refúgio no Brasil não escapa, nesse sentido, à lógica da oscilação entre as políticas da compaixão e da repressão, nos termos propostos por Fassin (2005) em sua análise do cenário francês. Conforme nos diz o autor, há um quadro ambivalente nas práticas e políticas de representação do sujeito refugiado, ora deslocado da esfera política para a esfera da compaixão, ora deslocado da tolerância relativa para a desconfiança geral. Teríamos, nesse contexto, a figura do refugiado cada vez mais subsumida à esfera do humanitarismo ou abarcada pela lógica policialesca. Em todo o caso, o refúgio deixa de ser representado como um direito e passa a ser tratado como evidência de um movimento que, ao mesmo tempo, ameaça a ordem (estatal) e gera comoção pública.

Os aspectos apontados na discussão sobre as representações do refúgio (e do refugiado) em termos quantitativos e nacionais, como o empobrecimento e a marginalização hermenêuticas, o imaginário social e os estereótipos e preconceitos, também atravessam este cenário em que a categoria do movimento surge entre as categorias do cuidado e do controle. A pluralidade de significados atribuídos à figura do refugiado, ora entendido como vítima, ora percebido como ameaça, traz à tona um quadro hermenêutico em que o sujeito que vive a experiência sofre um tratamento injusto sem instrumentos adequados para fazer oposição ao mesmo. Conforme vimos, a ausência da participação ativa dos refugiados na produção de significados sobre sua própria condição sócio-política faz com que interpretações com base em estereótipos e preconceitos sejam compartilhadas pelos grupos hermeneuticamente mais poderosos. Diante disso, os refugiados, já ausentes da produção de significados a partir de (e sobre a) sua própria experiência, também se tornam impossibilitados de se opor às imagens de vítima e ameaça que circulam na mídia e reforçam um determinado imaginário social a respeito da condição do refúgio.

A dinâmica desigual de produção de significados sobre determinadas experiências sociais, em um quadro de marginalização hermenêutica, permite interpretações errôneas ou preconceituosas acerca daquilo que é vivenciado por sujeitos marginalizados. Nesse sentido, ao lado dos exemplos oferecidos por Fricker (2007) para a compreensão deste cenário - o abuso sexual interpretado como flerte, o estupro no casamento visto como sexo, a depressão pós-parto 
entendida como histeria - é possível acrescentar a condição refugiada compreendida como vitimização ou ameaça ${ }^{48}$. Este tipo de marginalização está ligado a um preconceito estrutural nos recursos coletivos hermenêuticos que é essencialmente discriminatório, uma vez que afeta os sujeitos em função do seu pertencimento a determinado grupo social em posição de desvantagem nas relações de poder estabelecidas (Fricker, 2007). Assim, é em função de um determinado aspecto da identidade social de um sujeito (neste caso, sua identidade enquanto refugiado) que se dá o processo de marginalização hermenêutica, constituindo o quadro de preconceito identitário estrutural definido pela autora. Podemos compreender, assim, a injustiça hermenêutica como "a injustiça de ter uma área significativa da experiência social obscurecida em termos de conhecimento coletivo devido a um preconceito identitário estrutural nos recursos hermenêuticos coletivos" (Fricker, 2007, p.155).

A perspectiva trazida por Fricker enfatiza como, em todos os casos de um tipo essencialmente hermenêutico de injustiça, as lacunas ou gaps existentes nos recursos hermenêuticos coletivos operam uma redução significativa na inteligibilidade acerca da experiência do sujeito marginalizado. De maneira geral, todos os aspectos da representação midiática abordados aqui, o refúgio em números, a questão da nacionalidade e a alocação do movimento entre o cuidado e o controle, indicam a produção de significados sobre a experiência da condição refugiada a despeito da participação ativa dos sujeitos neste processo. Há, assim, a criação de um regime de significados e representações que desconsideram as dimensões individuais e subjetivas da experiência do refúgio, deslocando os próprios refugiados para as margens da agência política e social. Nesse sentido, se nos capítulos anteriores foi possível compreender o processo do refúgio por elegibilidade em seu papel na produção de uma injustiça epistêmica, com o progressivo desaparecimento do sujeito, também aqui podemos entender este processo reproduzido nas práticas de representação midiática. Em outras palavras, teríamos novamente um processo de desapropriação das narrativas, em que a injustiça epistêmica pode ser observada a partir da ausência de participação dos refugiados na produção de significados sobre suas próprias experiências. Conforme vimos, este quadro gera uma série de concepções atravessadas por estereótipos e

\footnotetext{
${ }^{48} \mathrm{E}$, conforme vimos no capítulo anterior, o refugiado entendido como fugitivo.
} 
preconceitos que reforçam um determinado imaginário social a partir de um lugar de empobrecimento e marginalização hermenêutica.

\section{6 \\ Conclusões}

As análises anteriores procuraram demonstrar como se deu o processo de produção de significados sobre o sujeito refugiado, a partir das representações midiáticas do período entre 2013 e 2017. A fim de realizar uma reflexão sobre o campo semântico do refúgio no Brasil, foi adotada uma abordagem de análise com corpus que, com a ajuda de softwares específicos, permitiu o acesso e a interpretação de uma ampla quantidade de textos compilados dos jornais online e portais de notícias mais acessados a partir do Brasil. A apresentação das análises e de seus principais resultados procurou preservar os procedimentos originais realizados, trazendo tanto uma dimensão léxica da análise, com o conjunto de palavras mais utilizadas em referência ao termo refugiad*, quanto uma dimensão gramatical, com a verificação dos verbos dos quais o refugiado é apresentado como sujeito e como objeto. A partir disso, procurou-se implementar ferramentas analíticas que considerassem a importância de técnicas não só quantitativas, mas também qualitativas, na análise dos dados. Conforme demonstrado no decorrer do capítulo, a análise buscou verificar, para além das freqüências e padrões quantitativos de representação, os contextos mais amplos em que os termos se encontravam inseridos, bem como a categorização possível do material. Procurei deixar claro, então, a participação subjetiva da pesquisadora em diversas etapas da pesquisa, com análises manuais detalhadas da concordância e com um processo de produção de categorias que foi amplamente debatido aqui.

A produção de significados pela mídia não esgota as dimensões interpretadas na presente pesquisa. Pelo contrário, a existência de um corpus extenso sobre o tema permite que diferentes pesquisadores façam interpretações diversas a partir do material analisado. Conforme procurei demonstrar, o processo de categorização e análise partiu dos interesses da pesquisa proposta, os quais se encontram diretamente relacionados à discussão sobre os espaços de habitação possível para o sujeito refugiado em diferentes campos pelos quais circula (seja diretamente, seja por meio de representações). A partir desta compreensão mais 
ampla, emergiram como cruciais para o trabalho analítico três aspectos específicos: o refúgio em números, a questão da nacionalidade e a alocação do movimento entre as dimensões do cuidado e do controle. A reflexão proposta trouxe para o centro do debate, então, os regimes de lugar, visibilidade e capacidade discursiva nos quais os sujeitos em situação de refúgio são alocados por uma determinada representação midiática de suas experiências. Tendo este quadro em mente, busquei refletir sobre a produção de um conjunto de significados e padrões representativos e o que isso poderia implicar em termos de uma injustiça epistêmica, especialmente em sua dimensão hermenêutica.

A representação do refúgio em números, com a ênfase sobre sua dimensão quantitativa, abriu espaço para o questionamento a respeito de um empobrecimento hermenêutico que produz lacunas de inteligibilidade acerca das experiências sóciopolíticas que motivaram o deslocamento forçado de determinados sujeitos. O que podemos ver afetado neste contexto é a possibilidade de compreensão do cenário complexo que constitui as origens da mobilidade dos refugiados, em nome de uma simplificação numérica que evidencia cenários caóticos em países de acolhida (notadamente europeus) que recebem tais fluxos. Teríamos, assim, um obstáculo às interpretações de aspectos da experiência do refúgio que poderiam ser do interesse dos refugiados tornar inteligível ao outro. Há, nesse sentido, um potencial para a veiculação de imagens distorcidas sobre o fluxo de pessoas enquanto uma espécie de desastre natural ou estado de crise em determinados países de suposta acolhida, o que pode produzir um imaginário social atravessado por preconceitos e estereótipos a respeito da condição refugiada.

A representação em termos de nacionalidade, por sua vez, chamou a atenção para a quase completa ausência da participação dos refugiados nos discursos midiáticos, evidenciando a desigualdade existente na produção de significados e conceitos sobre a experiência do refúgio. Este quadro trouxe à tona novamente a questão da inteligibilidade sobre a condição refugiada, uma vez que haveria uma marginalização hermenêutica que impede que os sujeitos diretamente implicados nesta condição possam fazer sentido das suas experiências e comunicá-las de maneira inteligível ao outro. A homogeneização da figura do refugiado e a sua ausência na produção de significados sobre a sua própria condição sócio-política trouxeram, então, questionamentos sobre a atuação de preconceitos enquanto às capacidades destes sujeitos para narrar experiências relevantes no campo do 
deslocamento forçado e da mobilidade que atravessa um regime de Estados. Os recursos hermenêuticos coletivos acabam tornando-se estruturalmente preconceituosos, pois as experiências sociais dos refugiados não são interpretadas e comunicadas pelos próprios refugiados, mas por membros de grupos hermeneuticamente mais poderosos.

Por último, mas não menos importante, a representação do movimento entre as categorias do cuidado e do controle levantou a questão da pluralidade de significados atribuídos à figura do refugiado, percebido tanto como vítima quanto como ameaça. Neste cenário, há pouco espaço para que os sujeitos refugiados possam fazer oposição a imagens preconceituosas ou marcadas por estereótipos que atravessam a condição do refúgio. Conforme vimos anteriormente, a ausência da participação ativa desses sujeitos na produção de significados sobre suas próprias experiências pode fazer com que interpretações distorcidas sejam compartilhadas pelos grupos hermeneuticamente mais poderosos. Diante disso, os refugiados se encontram impossibilitados de se opor, criticar ou questionar, por via de participação nos mesmos regimes de visibilidade midiática, as imagens de vítima e ameaça que são veiculadas e que contribuem para reforçar um determinado imaginário social sobre quem é o refugiado.

$\mathrm{O}$ arcabouço teórico inicial acerca da injustiça epistêmica foi mobilizado no decorrer desta tese não só em termos de análise do processo brasileiro de elegibilidade, mas também do campo semântico do refúgio no Brasil, como vimos aqui. Procurei analisar não somente as práticas epistêmicas que marcam as dimensões burocráticas e subjetivas do refúgio por elegibilidade, a partir do trabalho de campo com a realização de entrevistas, mas também um conjunto de recursos coletivos hermenêuticos, tendo em vista as representações midiáticas estudadas através da abordagem com corpus. No segundo e terceiro capítulos foi possível compreender um processo de desapropriação das narrativas e de desaparecimento dos sujeitos, cada vez mais subsumidos pela burocracia e pela "economia da credibilidade". Neste quarto e último capítulo tornou-se possível compreender uma espécie de continuidade desta dinâmica nas práticas de representação midiática sobre a experiência dos refugiados. Nesse sentido, busquei analisar as duas (interligadas) dimensões da injustiça epistêmica propostas inicialmente por Fricker (2007), ressaltando tanto as trocas testemunhais e avaliações de credibilidade realizadas a respeito dos refugiados e solicitantes de 
refúgio, quanto o regime de produção de significados sobre a condição refugiada e suas possíveis implicações em termos dos recursos hermenêuticos coletivos. A articulação entre as partes da presente tese, e entre este último capítulo e os capítulos anteriores, será retomada em maiores detalhes na conclusão final do trabalho, que desenvolvo a seguir. 


\section{6 \\ Considerações finais}

Nas considerações finais desta tese busco situar as contribuições da pesquisa a partir tanto do campo teórico da injustiça epistêmica quanto dos estudos sobre práticas de representação e elegibilidade no campo do refúgio. Retomo, assim, como uma reflexão sobre as dinâmicas da injustiça testemunhal e hermenêutica podem contribuir para a expansão da proposta original em torno do conceito de injustiça epistêmica e, principalmente, das discussões existentes sobre práticas de determinação de status e produção de significados sobre a figura do refugiado. Por fim, busco afirmar a abertura, a partir da pesquisa realizada, de condições de possibilidade para explorações futuras acerca das virtudes epistêmicas necessárias no debate sobre questões de (in) justiça e refúgio, bem como possíveis limitações da abordagem.

\section{1}

\section{Refúgio e injustiça epistêmica}

Ao longo desta tese busquei refletir sobre o refúgio a partir da ótica das práticas de produção de conhecimento e significados sobre a condição refugiada, tomando como objetos de análise o processo brasileiro de elegibilidade e a representação midiática dos refugiados na grande mídia brasileira. Em ambos, procurei utilizar como fio condutor da análise a lente teórica da injustiça epistêmica, testemunhal e hermenêutica, a fim de que fosse possível compreender aspectos centrais do modo como sujeitos refugiados são epistemicamente produzidos pelos sistemas de elegibilidade e representação. Tornou-se fundamental para esta tese, assim, a análise das condições de possibilidade para produção de conhecimento e participação ativa nas práticas de geração de significados sociais a partir da própria condição refugiada.

A análise das práticas do refúgio por elegibilidade ampliou a lente teórica utilizada por Fricker (2007), permitindo a incorporação de algumas das críticas elaboradas por autores que discutem o conceito de injustiça epistêmica. Um desses pontos de expansão pode ser compreendido a partir do papel das emoções ou percepções subjetivas nos julgamentos de credibilidade. Conforme vimos em detalhes ao longo do terceiro capítulo desta tese, aspectos subjetivos desempenham papel fundamental nas análises do testemunho de solicitantes de refúgio, podendo 
contribuir para a produção de injustiças epistêmicas. Nesse sentido, é possível argumentar, com Origgi (2012), que um quadro de injustiça testemunhal pode ser impactado por outros mecanismos, para além dos preconceitos e estereótipos daqueles responsáveis por analisar a credibilidade dos sujeitos. Embora Fricker (2007) reconheça que o preconceito não é o único fator que pode influenciar a atribuição injusta de um déficit de credibilidade, ela ainda considera o preconceito identitário como sendo o caso central da injustiça testemunhal. $\mathrm{Na}$ análise do refúgio por elegibilidade foi possível identificar a existência de outros mecanismos, como as reações emocionais, que podem influenciar de maneira significativa a atribuição de credibilidade aos sujeitos e seus testemunhos. A análise permitiu, então, a incorporação das críticas desenvolvidas por Origgi (2012) a respeito da limitação de uma abordagem da injustiça epistêmica que só leve em consideração o papel de preconceitos.

Um segundo ponto fundamental de expansão da abordagem da injustiça epistêmica conforme Fricker (2007) surgiu a partir da análise da relação entre déficits e excessos de credibilidade no processo brasileiro de determinação do status de refugiado. Para Fricker (2007), a injustiça testemunhal deve ser concebida como uma questão de déficit - e não excesso - de credibilidade, uma vez que atribuir excessos de credibilidade não significaria perpetrar uma injustiça contra alguém enquanto sujeito do conhecimento. Conforme vimos no primeiro capítulo, tal perspectiva é tensionada por Medina (2011), que afirma a relação íntima entre déficits e excessos de credibilidade na produção de injustiças epistêmicas. Assim, para o autor, haveria um privilégio epistêmico envolvido na atribuição de excessos de credibilidade, uma vez que implicaria "o tratamento imerecido de um sujeito epistêmico que recebe comparativamente mais confiança do que outros sujeitos nas mesmas condições" (Medina, 2011, p.20). No decorrer desta tese, a noção de privilégio epistêmico desempenhou papel central na compreensão das posições desfrutadas pelos "técnicos do refúgio" no processo de julgar a credibilidade dos solicitantes. Vimos emergir, então, o que chamei aqui de um grupo de "notáveis" capazes de saber pela expertise, que disputam compreensões sobre a figura do refugiado a partir de argumentos supostamente técnicos sobre a credibilidade dos sujeitos, restringindo a participação ativa dos solicitantes e refugiados no processo. A análise do caso brasileiro permitiu compreender, assim, que um privilégio epistêmico pode ser atravessado pela desconfiança na capacidade de produção e 
transmissão do conhecimento por aqueles impedidos de desfrutar da mesma posição epistêmica.

Para além de contribuir com a possibilidade de expansão da lente teórica da injustiça epistêmica, situando-se no campo de debates e dialogando com as críticas existentes, esta tese também buscou oferecer novas possibilidades de compreensão do próprio processo do refúgio por elegibilidade. $\mathrm{O}$ detalhamento das diferentes etapas burocráticas e dos procedimentos de determinação do status de refugiado permitiu a identificação de dois pontos em comum nas dinâmicas da injustiça epistêmica no seio da elegibilidade: 1) um gradual desaparecimento dos solicitantes no processo, com a desapropriação das narrativas e obstáculos a sua participação e 2) o papel central de uma "economia da credibilidade" (Fricker, 2007) afetada por preconceitos, estereótipos e percepções subjetivas, bem como pela relação entre excessos e déficits de credibilidade. A partir deste quadro, tornou-se possível compreender a existência, nas práticas da elegibilidade, de restrições ao conhecimento dos solicitantes e refugiados e entraves a sua participação no processo, ao mesmo tempo em que determinados sujeitos, como os "técnicos do refúgio", desfrutariam de um privilégio epistêmico fundamental para produzir a figura do refugiado.

No campo de análise dos processos de elegibilidade que regem o refúgio, no Brasil e no mundo, muito foi escrito sobre o caráter de investigação da verdade sobre a vida e as narrativas dos solicitantes que regem os procedimentos de análise de credibilidade. Há diversas análises, assim, sobre o papel central que a credibilidade exerce nos processos e a instauração de uma cultura da descrença (Alexander, 1999; Jubany, 2011, 2017; Souter, 2011; Weston, 1998) que parte do pressuposto de que o solicitante de refúgio é um trapaceiro em potencial, em busca de manipular o sistema para se beneficiar indevidamente de uma proteção que não lhe é destinada. Reconhecendo a existência dessas reflexões teóricas e propondo uma análise a partir de tais considerações centrais para pensar o refúgio por elegibilidade, esta tese buscou repensar o processo à luz das práticas epistêmicas de transmissão do conhecimento e produção de significados sociais a partir da condição refugiada.

Mais do que uma investigação sobre a verdade, o processo da elegibilidade emerge, assim, como um espaço de (re) produção de formas de injustiça epistêmica que afetam a capacidade de participação ativa dos solicitantes e refugiados e produz 
os sujeitos merecedores do status a partir de posições de privilégio epistêmico. Vimos, então, que a credibilidade dos solicitantes pode ser minada pela existência de uma série de fatores que influenciam o processo, como preconceitos, estereótipos e percepções subjetivas ou reações emocionais dos "técnicos do refúgio". A determinação da figura do refugiado parte, em grande medida, das imagens e perspectivas desses atores ao passo que marginaliza e exclui o conhecimento dos próprios solicitantes e refugiados, impedidos de participar ativamente da comunidade de informantes, isto é, dos sujeitos capazes de produzir e compartilhar conhecimento a partir de suas experiências. A produção epistêmica de sujeitos refugiados pelo sistema da elegibilidade permite, então, que as narrativas dos solicitantes sejam eclipsadas e desapropriadas em nome da expertise dos "técnicos do refúgio”. Estes não estão livres, porém, da influência de aspectos subjetivos e preconceituosos em suas análises de credibilidade que determinam, em última instância, quem é um refugiado.

A análise sobre a figura do refugiado não foi realizada aqui apenas a partir da dimensão da elegibilidade, mas também procurei abordar formas de representação midiática sobre o refúgio que atribui significados aos sujeitos e indica a existência de uma baixa inteligibilidade sobre suas experiências para além dos processos de determinação do status. A tese também procurou contribuir, assim, para compreensões acerca de como os sujeitos em condição de refúgio podem constituir um grupo social em desvantagem hermenêutica, com a marginalização de suas experiências sociais e da produção de significados a partir delas. O desaparecimento dos solicitantes e refugiados como sujeitos de conhecimento capazes de produzir significados não se restringe, então, aos processos de elegibilidade, mas pode ser encontrado também nas formas de representação da grande mídia brasileira. Esta ausência indica um processo de empobrecimento dos recursos coletivos hermenêuticos, que acabam se tornando estruturalmente preconceituosos, uma vez que as interpretações das experiências do refúgio não são produzidas nem influenciadas pelos seus próprios sujeitos, mas por membros de grupos hermeneuticamente mais poderosos (Fricker, 2006).

A tese abre caminho, assim, para a possibilidade de análise de práticas de representação para além das discussões existentes sobre os processos de vitimização e marginalização de sujeitos (Boltanski, 1999; Fassin, 2005, 2007; Soguk, 1999) ou sobre a manutenção de uma desigualdade ontológica entre eles 
(Fassin, 2007). Como forma de contribuição original, as discussões da tese estiveram centradas em temas de marginalização e exclusão epistêmica dos refugiados, com seus impactos possíveis em termos de uma injustiça hermenêutica. A chave teórica da injustiça epistêmica ofereceu, então, um instrumento analítico poderoso para analisarmos as formas de representação a partir de processos excludentes que afetam os regimes de produção de significados para além das trocas testemunhais do refúgio por elegibilidade. Ao acompanhar a vida dos refugiados, escapando dos espaços burocráticos de concessão do status, a marginalização e a exclusão epistêmica desses sujeitos podem indicar a existência de uma dimensão opressiva da injustiça que recai sobre tais vidas. Dessa maneira, as análises aqui desenvolvidas trazem a possibilidade de reflexões voltadas ao caráter opressor que pode estar contido em um quadro de injustiça epistêmica e pode impactar, então, a vida dos solicitantes e refugiados.

Quando a injustiça epistêmica é persistente e sistemática, como os casos centrais trabalhados por Fricker (2007), seu impacto pode ser extremamente prejudicial. O mal causado por esse tipo de injustiça é compreendido pela autora como uma forma de prejudicar não apenas o sujeito injustiçado, mas também a prática ou o sistema epistêmico como um todo. Isso porque, segundo Fricker (2007, p.43), “o preconceito apresenta um obstáculo à verdade, seja diretamente, ao fazer com que o interlocutor perca uma verdade particular que está sendo transmitida pelo sujeito que fala, seja indiretamente, ao criar bloqueios à circulação de idéias críticas". Ainda que a autora considere o impacto político desse tipo de injustiça, uma vez que determinados sujeitos ficam impedidos de produzir conhecimento no espaço público, o que revela uma ausência de liberdade na situação discursiva na polis, o foco das análises é na interseção entre a epistemologia e a ética. Para Fricker, assim, torna-se fundamental não apenas o impacto sobre a capacidade de determinadas pessoas enquanto sujeitos do conhecimento e sobre o sistema político em termos de liberdade de circulação de idéias, mas também - e principalmente o impacto sobre uma capacidade que é central para a valoração humana. Conforme a autora nos diz, "em todos os casos de uma injustiça testemunhal, o que a pessoa sofre não é apenas o mal epistêmico em si, mas o significado de ser tratado de tal forma" (Fricker, 2007, p.44).

Fricker nos diz que a capacidade da razão, isto é, a racionalidade, é precisamente aquilo que dá à humanidade seu valor distintivo, conforme a própria 
história da filosofia demonstra. Nesse sentido, em contextos de opressão, aqueles que estão situados em melhores posições de poder buscam minar a capacidade da razão daqueles menos favorecidos politicamente, uma vez que tal prática permite a diminuição da humanidade dos sujeitos (Fricker, 2007). Para a autora, a "face da opressão" (idem, p.58) na injustiça epistêmica sofrida por determinados sujeitos ocorre justamente em situações de degradação que afetam os seres humanos em sua racionalidade de maneira persistente e sistemática. Assim, tanto a injustiça hermenêutica quanto a injustiça testemunhal podem apresentar um caráter opressor quando o preconceito ou a marginalização acompanham os sujeitos em diferentes atividades sociais, deixando-os suscetíveis a outras formas de injustiça. Fricker nos diz, então, que uma injustiça epistêmica persistente e sistemática deriva de desigualdades estruturais de poder que deixam os sujeitos suscetíveis a diferentes tipos de injustiça. Mais do que isso, para a autora, uma injustiça do tipo hermenêutico tenderá a ser sistemática quando ela for composta pela injustiça testemunhal, uma vez que "membros de grupos marginalizados tenderão a estarem sujeitos ao preconceito identitário" (Fricker, 2007, p.159).

A tese contribui, assim, para lançar luz sobre a possibilidade de um caráter opressor que atravessa a injustiça epistêmica no caso dos solicitantes e refugiados. Ainda que não tenhamos buscado analisar outros tipos de injustiça, para além da epistêmica, as reflexões sobre processos de marginalização hermenêutica nas práticas de representação e a influência de preconceitos, estereótipos e percepções subjetivas nos julgamentos de credibilidade demonstraram a possível interligação entre os tipos de injustiça aqui trabalhados. Nesse sentido, e ainda tendo a perspectiva de Fricker como inspiração, as análises da tese sugerem a possibilidade de que solicitantes e refugiados possam ser duplamente injustiçados em termos epistêmicos: tanto por preconceitos estruturais nos recursos hermenêuticos coletivos, quanto por preconceitos nos julgamentos de credibilidade.

Partir do pressuposto levantado por Fricker (2007) de que a injustiça hermenêutica se manifesta, tipicamente, na luta do sujeito que fala em fazer-se inteligível em uma troca testemunhal ${ }^{49}$, levantando a possibilidade da interligação

\footnotetext{
${ }^{49}$ Fricker (2007) nos diz que o fato de que a injustiça hermenêutica tende a manifestar-se em tentativas de comunicação chama a atenção para uma versão diferente da injustiça, uma vez que não haveria apenas gaps ou lacunas em relação ao conteúdo do que é dito, mas também no que diz respeito à forma daquilo que é dito. Assim, segundo a autora, a o estilo expressivo de membros de determinados grupos sociais, por exemplo, pode ser tão importante no esforço da troca testemunhal
} 
entre os dois tipos de injustiça, fez com que a análise realizada nesta tese buscasse abordar a injustiça para além do espaço da elegibilidade. Considero, dessa forma, que as reflexões tecidas em torno tanto das práticas de representação quanto das práticas da elegibilidade proporcionam um ganho em termos do esforço em pensar um cenário marcado por uma desigualdade estrutural de poder que oprime os sujeitos. Abre-se caminho, com isso, para que outras análises, que levem em conta formas diferentes de injustiça, possam contribuir para um melhor entendimento acerca do caráter opressor que pode marcar uma injustiça epistêmica, afetando as vidas dos solicitantes e refugiados em esferas múltiplas e distintas.

\section{2}

\section{Refúgio e justiça epistêmica}

Esta tese não explorou, a partir do caso brasileiro, as condições de possibilidade para produção de um quadro de justiça epistêmica. Apesar disso, considero que abrimos caminho aqui para explorações futuras acerca do que pode ser feito a fim de corrigir preconceitos e gaps estruturais no campo do refúgio no país e, com isso, no tratamento epistêmico dado aos refugiados. Tendo tais preocupações em mente, busco concluir o trabalho retomando algumas discussões teóricas realizadas no primeiro capítulo sobre uma virtude epistêmica como correção para quadros de injustiça testemunhal e hermenêutica. Espero, a partir desse movimento, recuperar brevemente a análise realizada desde o espaço de abertura produzido como forma de repensar questões de justiça atreladas ao refúgio no Brasil, indicando possibilidades futuras de reflexão e limitações existentes nesta abordagem.

Nas discussões teóricas analisadas no capítulo inicial desta tese vimos como emerge, no campo da injustiça epistêmica, a noção da importância de uma consciência crítica reflexiva sobre o lugar social dos sujeitos nas interações. Especificamente no quadro de uma injustiça testemunhal, haveria a necessidade de uma reflexão crítica dos sujeitos sobre sua própria atuação em julgamentos de credibilidade. Tal esforço subjetivo seria fundamental, assim, para diminuir o

quanto a presença ou a ausência de significados sobre experiências sociais. Conforme vimos no decorrer da tese, os estilos narrativos apresentados por solicitantes no processo de elegibilidade também são fundamentais nas práticas de julgar a credibilidade dos sujeitos e dos seus testemunhos, podendo impactar a própria compreensão das experiências narradas. 
impacto de preconceitos e estereótipos nas trocas testemunhais e, com isso, alcançar interações mais justas e éticas. A virtude necessária para a produção de um quadro de justiça epistêmica seria, então, e ao mesmo tempo, uma virtude intelectual e ética baseada na motivação de diminuir o impacto de preconceitos nos julgamentos de credibilidade (Fricker, 2007). Diferentes perspectivas (Fricker, 2003, 2007; Hookway, 2010; Marsh, 2011) consideram, dessa maneira, que uma forma essencial de combate à injustiça epistêmica está ligada ao desenvolvimento de uma virtude reflexiva anti-preconceituosa capaz de enfrentar as disfunções epistêmicas no âmbito de uma injustiça testemunhal.

Mesmo no caso de uma injustiça hermenêutica, Fricker (2007) considera a importância de exercer o que ela chama de uma sensibilidade reflexiva ou uma virtude da justiça hermenêutica que opera também de maneira corretiva. Tal virtude abriria espaço, nesta perspectiva, para a possibilidade de que problemas na inteligibilidade da comunicação sejam entendidos em termos de gaps nos recursos hermenêuticos coletivos - e não como um problema exclusivo do sujeito que narra. É importante salientar, assim, que a autora desenvolve sua noção de virtude da justiça hermenêutica também no quadro das trocas testemunhais, considerando a interligação entre ambas, conforme vimos. Tendo em vista a existência de ênfases sobre a dimensão individual de uma virtude corretiva às injustiças epistêmicas, autores como Alcoff (2010) questionam a eficácia de uma prática que opera apenas na esfera consciente das vontades humanas como forma de combater um problema que também possui raízes estruturais. Para esta autora, ainda que consideremos apenas a dimensão testemunhal de uma injustiça, como esperar que sujeitos desenvolvam livremente uma postura virtuosa orientada para a justiça epistêmica quando preconceitos podem atuar mesmo contra valores e compromissos sustentados conscientemente? Em outras palavras, se preconceitos atuam, por vezes, através de imagens coletivas inconscientes, como podemos combater a injustiça epistêmica a partir de práticas que dependam do esforço consciente e individual dos sujeitos?

Fricker (2010) não deixa de considerar a crítica levantada por Alcoff (2010) e desenvolver sua resposta de modo a afirmar a necessidade de uma articulação entre virtudes reflexivas individuais e mecanismos estruturais corretivos. A autoregulação não seria, assim, a única forma de combate à injustiça epistêmica, mas seria necessário também o desenvolvimento de mecanismos estruturais. A autora 
não propõe análises, porém, voltadas à reflexão sobre as formas estruturais de combate à injustiça epistêmica, mas parece produzir uma narrativa que reforça seu ponto de partida sobre a importância de posturas críticas reflexivas no próprio esforço inicial de criação de mecanismos estruturais. Tanto em resposta à Alcoff quanto em suas reflexões na obra central para discussão do conceito de injustiça epistêmica, Fricker $(2007,2010)$ concentra suas análises na noção de uma virtude epistêmica da justiça testemunhal e hermenêutica, deixando a desejar em termos de uma discussão sobre relações desiguais de poder que criam as próprias condições para a manifestação das injustiças epistêmicas.

É preciso considerar, assim, a existência de limitações importantes na abordagem sobre formas de produzir justiça epistêmica no campo do refúgio por elegibilidade e por representação. Ainda que diversos autores (Fricker, 2003, 2007; Hookway, 2010; Marsh, 2011) afirmem a relevância de mecanismos estruturais para combater injustiças testemunhais e hermenêuticas, a ênfase de suas perspectivas permanece centrada na noção do desenvolvimento de virtudes reflexivas capazes de combater o preconceito e demais disfunções epistêmicas em trocas testemunhais. Ao refletirmos, porém, sobre uma dimensão hermenêutica da injustiça epistêmica nas práticas de representação midiática sobre a figura do refugiado, por exemplo, é possível evidenciar a insuficiência de uma abordagem que não coloque no centro de suas análises a preocupação com relações estruturais desiguais de poder. Foi precisamente por considerar tais limitações no campo de debates em torno da justiça epistêmica como virtude individual que busquei inserir contribuições externas a partir de uma perspectiva foucaultiana. Ainda que o objetivo não tenha sido me deter sobre análises do autor sobre o nexo saber-poder, a sinalização breve de um possível diálogo com sua obra é o que pretendo reafirmar aqui como modo de abrir caminho para explorações futuras no campo não mais da injustiça especificamente, mas da justiça epistêmica.

Conforme vimos no capítulo inicial, a noção foucaultiana de virtude em suas articulações com a idéia de crítica permite que comecemos a questionar a própria maneira pela qual uma virtude da justiça epistêmica é desenvolvida. Para Foucault (2007), a virtude deve ser concebida como uma relação crítica com as normas préestabelecidas, isto é, como uma forma de estar no mundo que busca opor-se às inúmeras maneiras de exercício do poder. Mais especificamente, a virtude em termos foucaultianos envolveria repensar nossas concepções de verdade a fim de 
lançar luz sobre as relações de poder que constituem o que vai ser aceito como um campo de conhecimento (Butler, 2001). Conforme nos diz Butler, a partir de sua análise de Foucault, a atitude crítica envolve expor as articulações entre o conhecimento e o poder, as quais operam para produzir um modo mais ou menos sistemático de ordenar o mundo. A partir dessa noção de virtude enquanto crítica seria necessário repensar, então, todo um campo epistemológico (Butler, 2001).

Se começamos a pensar, com Foucault e Butler, a virtude em termos da crítica à constituição e manutenção de um determinado campo de coisas inteligíveis, a abordagem sobre uma postura virtuosa constituída por aberturas e sensibilidades em julgamentos de credibilidade acaba se tornando insuficiente. A produção de ajustes na capacidade de escuta e nos modos de avaliação das verdades do outro não seria suficiente, assim, para questionar um sistema em sua "arbitrariedade em termos de conhecimento e sua violência em termos de poder" (Foucault, 2007, p.59). A abordagem sobre a virtude da justiça epistêmica parece ignorar as relações entre conhecimento e poder, não dando conta de analisar criticamente um regime de produção de significados que desconsidera a participação dos próprios sujeitos que busca representar. Não busco afirmar, com isso, que tal abordagem pretenda a realização de tal tarefa, mas ressalto aqui suas limitações e insuficiências em termos de uma análise futura sobre questões de justiça no campo do refúgio. Considero essencial, assim, que uma pretensão de combate a formas de injustiça testemunhal e hermenêutica nas práticas de representação e elegibilidade analisadas aqui levantem questionamentos básicos, mas fundamentais, sobre nossas certezas epistemológicas. Restringir a crítica aos espaços de troca testemunhal faz com que ignoremos um regime mais amplo que produz significados e conhecimento sobre a figura do refugiado, multiplicando imagens midiáticas muitas vezes descoladas das experiências vividas pelos sujeitos.

Abrir caminho para explorações futuras sobre questões de justiça e poder no campo do refúgio é, então, questionar os limites daquilo que podemos saber - seja através da mídia, seja através de um regime burocrático responsável por determinar quem é um refugiado. Dentro deste quadro é possível questionar, por exemplo, os limites da inteligibilidade nas trocas testemunhais do refúgio por elegibilidade, especialmente se levarmos em conta aquilo que Butler (2017) chama de parcialidade de todo relato que damos sobre nós mesmos. Conforme vimos no capítulo inicial com a análise breve das contribuições desta autora, a parcialidade 
dos relatos autonarrativos impede que o sujeito ofereça um relato completo, único e verdadeiro sobre si mesmo. Butler nos diz, então, que podemos recontar uma determinada história sobre nós mesmos diversas vezes e de diferentes maneiras, mas sem podermos afirmar a existência de uma única narrativa verdadeira sobre nós. Todo relato de si é parcial, segundo a autora, e aponta a existência de algo que escapa à possibilidade narrativa do próprio sujeito e, com isso, à compreensão do outro. Nesse sentido, as práticas da elegibilidade são atravessadas por um problema fundamental inerente ao fracasso de todo projeto autonarrativo, para usar os termos de Butler (2017).

Seria preciso considerar, segundo a perspectiva de Butler, que há algo no solicitante de refúgio (que também existe em cada um de nós) sobre o qual nem ele mesmo consegue produzir um relato. Se a vida emerge, nesse contexto, como excesso, isto é, como "aquilo que excede qualquer relato que dela possamos dar" (Butler, 2017, p.61), é preciso abrir mão da expectativa - e exigência - sobre um relato do sujeito que seja totalmente satisfatório. Abrir espaço para a crítica radical desenvolvida por Butler acerca da nossa capacidade enquanto seres autobiográficos coerentes faz com que possamos questionar todo o edifício sobre o qual se erigiu o refúgio por elegibilidade. $\mathrm{O}$ convite da autora ao engajamento com aquilo que não pode ser facilmente traduzido pelos formatos narrativos - momentos de interrupção, obstrução e indefinição - abre caminho para a crítica à legitimidade dos julgamentos de credibilidade empregados como meio de determinação da condição refugiada. Nesse sentido, para que seja possível produzir reflexões futuras sobre questões de justiça epistêmica no campo do refúgio é necessário ir além da perspectiva sobre virtudes reflexivas como simples forma de ajuste em uma “economia da credibilidade" (Fricker, 2007). Faz-se premente, então, questionar a produção epistêmica de sujeitos refugiados e suas bases assentadas em uma busca incessante pela verdade das narrativas e pela adaptação das vidas às expectativas do regime de proteção internacional.

Se, conforme vimos, a proposta original de uma análise sobre injustiça epistêmica se posiciona na interseção entre a ética e a epistemologia, considero que pode ser analiticamente útil explorações futuras sobre refúgio e justiça epistêmica que se detenham sobre as contribuições filosóficas de Butler (2017) sobre posturas éticas nas práticas de reconhecimento do outro. $\mathrm{O}$ uso incipiente da obra desta autora no capítulo inicial pretendeu lançar as bases, assim, para a abertura de 
caminhos em relação ao debate sobre a dimensão ética do reconhecimento. Mais do que uma virtude reflexiva, seria preciso considerar, então, uma articulação séria entre o campo ético e o campo epistemológico, abrindo mão da expectativa de captura completa do outro em práticas de questionamento sobre sua identidade. A tarefa complexa, mas necessária, de repensar o instituto do refúgio e seu modo de produção de sujeitos refugiados passaria, nesse sentido, pela apreensão dos limites epistêmicos do relato de si mesmo e do reconhecimento do outro, nos termos de Butler. Seria preciso questionar, então, um sistema baseado em julgamentos de credibilidade, reabrindo a possibilidade para uma postura ética no reconhecimento dos sujeitos, considerando criticamente que "nos baseamos em juízos de culpa ou inocência para resumir a vida do outro, confundindo postura ética com aquele que julga" (Butler, 2017, p.63).

Esta tese não buscou explorar soluções em termos de uma justiça epistêmica como resposta às práticas atuais no campo do refúgio, nem mesmo propôs um engajamento suficientemente reflexivo com as contribuições de autores como Butler e Foucault. É verdade, porém, que busquei empreender um esforço - ainda que tímido - de abertura de caminhos possíveis para explorações futuras sobre a temática. É possível compreender, assim, as análises desenvolvidas durante a pesquisa como forma de perceber o refúgio a partir da chave analítica da injustiça epistêmica e, com isso, dar início à dura tarefa de distanciar-nos da pretensão da captura completa do outro. Seria necessário abrir espaço para considerar que a vida é o excesso que escapa a qualquer tentativa de enquadramento pelos regimes de representação e determinação de status que parecem reproduzir a categoria do refugiado à revelia das experiências múltiplas, ambivalentes, caóticas e, portanto, incapturáveis, dos sujeitos. 


\section{Referências bibliográficas}

ADLER, E.; POULIOT, V. International Practices. In: International Theory. 1.ed. Cambridge: Cambridge University Press, 2011 . p. 1-36. ALCOFF, L. Epistemic Identities. Episteme, v.7, n.2, p.128-137, 2010. ALEXANDER, M. Refugee Status Determination Conducted by UNCHR. International Journal of Refugee Law, v.11, n.2, p.251-289, 1999.

Alto Comissariado das Nações Unidas para os Refugiados (ACNUR). Convenção de 1951 Relativa ao Estatuto dos Refugiados. Genebra: ACNUR, 1951. Disponível em:

http://www.acnur.org/t3/fileadmin/Documentos/portugues/BDL/Convencao _relativa_ao_Estatuto_dos_Refugiados.pdf. Acesso em: 15 Jun de 2017.

Genebra: $\begin{gathered}\text { Protocolo de } 1967 \text { Relativo ao Estatuto dos Refugiados. } \\ \text { ACNUR, } 1967 .\end{gathered}$ http://www.acnur.org/fileadmin/scripts/doc.php?file=fileadmin/Documentos/ portugues/BD_Legal/Instrumentos_Internacionais/Protocolo_de_1967 Acesso em: $1 \overline{5}$ Jun de 2017. . Manual de Procedimentos e Critérios para a Determinação da Condição de Refugiado. Genebra: ACNUR, 2011. Disponível em:http://www.acnur.org/fileadmin/scripts/doc.php?file=fileadmin/Docume ntos/portuguesPublicacoes/2013/Manual_de_procedimentos_e_criterios_ para_a_determinacao_da_condicao_de_refugiado.Acesso em: 15 Jun de 2017.

$\begin{array}{ccc} & \text { ACNUR, } & \text { Credibility Assessment in EU Asylum Systems. Genebra: } \\ 2013 . & \text { Disponível }\end{array}$ http://www.unhcr.org/protection/operations/51a8a08a9/full-report-beyondproof-credibility-assessment-eu-asylum-systems.html. Acesso em: 14 jun. 2017.

Tendências Globais. Genebra: ACNUR, 2017. Disponível em: https://www.acnur.org/portugues/2018/06/19/mais-de-68-milhoes-depessoas-deslocadas-em-2017-e-essencial-um-novo-acordo-global-sobrerefugiados/ Acesso em: 10 dez 2018.

ALLEN, W.; BLINDER, S. Migration in the News. Portrayals of Immigrants, Migrants, Asylum Seekers and Refugees in National British Newspapers, 2010-2012. Migration Observatory Report, COMPAS, University of Oxford, 2013.

AMOORE, L. Biometric Borders: Governing Mobilities in the War of Terror. Political Geography, v.25, n.3, p.336-351, 2006.

ANDERSON, E. Epistemic Justice as a Virtue of Social Institutions. Social Epistemology: A Journal of Knowledge, Culture and Policy, v.26, n.2, p.163-173, 2012.

ARCHER, D; RAYSON, P. Using the UCREL Automated Semantic Analysis System to Investigate Differing Concerns in Refugee Literature. In: Keywords Workshop, 2004, Londres: King's College London. Não paginado. 
AUDI, R. Epistemology. A Contemporary Introduction to the Theory of Knowledge. 3.ed. Nova lorque: Routledge, 2010. 404p.

BAEHR, J. The Structure of Open-Mindedness. Canadian Journal of Philosophy, v.41, n.2, p.191-2013, 2011.

BAILEY, A. On Anger, Silence, and Epistemic Injustice. Royal Institute of Philosophy Supplement, v.84, p.93-115, 2018.

BAKER, P. Sociolinguistics and Corpus Linguistics. 1.ed. Edimburgo: Edinburgh University Press, 2010. 189p.

BAKER, P. et.al. A useful methodological synergy? Combining critical discourse analysis and corpus linguistics to examine discourses of refugees and asylum seekers in the UK press. Discourse \& Society, v.19, n.3, p.273-306, 2008.

BAKER, P.; GABRIELATOS, C.; MCENERY, T. Sketching Muslims: A Corpus Driven Analysis of Representations Around the Word 'Muslim' in the British Press 1998-2009. Applied Linguistics, v.34, n.3, p.255-278, 2013. BERGLUND PRYTZ, Y. Refugee or Migrant? What Corpora Can Tell. Nordic Journal of English Studies, v.15, n.2, p.47-61, 2016.

BHABHA, H. O Local da Cultura. Belo Horizonte: Editora UFMG, 1998. 395p.

BIGO, D.; WALKER, R. B. J. (2007) Political Sociology and the Problem of the International. Millennium: Journal of International Studies, v.35, n.3, p.725-739, 2007.

BOHMER, C.; SHUMAN, A. Producing epistemologies of ignorance in the political asylum application process. Identities, v.14, n.5, p.603-629, 2007. BOLTANSKI, L. Distant Suffering: Morality, Media and Politics. 1ed. Cambridge: Cambridge University Press, 1999. 246p.

BRASIL. Lei no 9.474, de 22 de julho de 1997. Define mecanismos para a implementação do Estatuto dos Refugiados de 1951, e determina outras providências.

Disponível

em: http://www.planalto.gov.br/ccivil 03/leis/L9474.htm. Acesso em: 21 out. 2018.

BRASIL. Refúgio em Números. Ministério da Justiça e Segurança Pública, Brasília, DF, 2017. Disponível em: https://www.acnur.org/portugues/wpcontent/uploads/2018/01/refugio-em-numeros-2010-2016.pdf Acesso em: 10 dez 2018.

BUTLER, J. What is critique? An Essay on Foucault's Virtue. Eipcp Multilingual Webjournal, 2001. Disponível em: http://eipcp.net/transversal/0806/butler/en/print. Acesso em: 15 Jan de 2019.

Relatar a Si Mesmo: Crítica da Violência Ética. 1.ed. Belo Horizonte: Autêntica Editora, 2017. 196p.

CALLON, M. Some Elements of a Sociology of Translation: Domestication of the Scallops and The Fishermen of St Brieuc Bay. In:

Power, Action, and Belief. Londres: Routledge \& Kegan Paul, 1986. p. 196-233. CAMERON, $\mathrm{H}$. Refugee Status Determination and the Limits of Memory. International Journal of Refugee Law, v.22, n.4, p.469-511, 2010.

CAREL, H.; KIDD, I. J. Epistemic Injustice in Healthcare: A philosophical Analysis. Medicine Health Care and Philosophy, v.17, n.4, p.529-540, 2014. 
CHOULIARAKI, L. The Ironic Spectator: Solidarity in the Age of Post Humanitarianism. 1.ed. Londres: Polity Press, 2013. 238p.

CZARNIAWSKA, B. Shadowing and Other Techniques for Doing Fieldwork in Modern Societies. 1.ed. Copenhagen: CBS Press, 2007. $134 p$.

DANIEL, E. V.; KNUDSEN, J. C. Mistrusting Refugees. 1.ed. Califórnia: University of California Press, 1996. 330p.

DOTSON, K. Tracking Epistemic Violence, Tracking Practices of Silencing. Hypatia, v.26, n.2, p.236-257, 2011.

DOTY, R. States of Exception on the Mexico-US Border: Security, 'Decisions' and Civilian Border Patrols. International Political Sociology, v.1, n.2, p.113-137, 2007.

ELLIS, J. M. Language, Thought and Logic. 1.ed. Illinois: Northwestern University Press, 1993. 166p.

FACUNDO, A. Êxodos, Refúgios e Exílios. Colombianos no Sul e Sudeste do Brasil. 1.ed. Rio de Janeiro: Papeis Selvagens, 2017. 388p. FASSIN, D. Compassion and Repression: the Moral Economy of Immigration Policies in France. Cultural Anthropology, v.20, n.3, p.362387, 2005.

n.3, p.499-520, 2007.

Humanitarianism as a Politics of Life. Public Culture, v.19,

FOUCAULT, M. Poder e Saber. In:_ Ditos e Escritos, v.IV. 4.ed. Rio de Janeiro: Forense Universitária, 2003. PÁGINAS DO CAPÍTULO.

The Politics of Truth. 2.ed. Los Angeles: Semiotext(e),

2007. 200p.

2008.

Nascimento da Biopolítica. São Paulo: Martins Fontes,

NAU, 2013. 152p.

A Verdade e as Formas Jurídicas. 4.ed. Rio de Janeiro:

FOTOPOULOS, S.; KAIMAKLIOTI, M. Media Discourse on the Refugee Crisi: On What have the Greek, German and British Press focused? European View, v.15, p.265-279, 2016.

FRICKER, M. Epistemic Oppression and Epistemic Privilege. Canadian Journal of Philosophy, v.29, n.1, p.191-210, 1999.

. Epistemic Injustice and a Role for Virtue in the Politics of Knowing.

Metaphilosophy, v.34, n.1-2, p.153-173, 2003.

. Powerlessness and Social Interpretation. Episteme: A Journal

of Social Epistemology, v.3, n.1-2, p.96-108, 2006.

Epistemic Injustice. Power \& the Ethics of Knowing. 1.ed.

Nova lorque: Oxford University Press, 2007. 188p.

. Replies to Critics. Theoria, v.23, n.61, p.81-86, 2008.

. Replies to Alcoff, Goldberg, and Hookway on Epistemic Injustice.

Episteme: A Journal of Social Epistemology, v.7, n.2, p.164-178, 2010. GABRIELATOS, C.; BAKER, P. Fleeing, Sneaking, Flooding: A Corpus Analysis of Discursive Constructions of Refugees and Asylum Seekers in the UK Press, 1996-2005. Journal of English Linguistics, v.36, n.1, p.538, 2008.

GIBB, R.; GOOD, A. Interpretation, Translation and Intercultural Communication in Refugee Status Determination Procedures in the UK and 
France. Language and Intercultural Communication, v.14, n.3, p.385399, 2014.

GORLICK, B. Common Burdens and Standards: Legal Elements in Assessing Claims to Refugee Status. New Issues in Refugee Research, Working Paper, n.68, p.1-17, 2002.

GRAHAM, M. Emotional Bureaucracies: Emotions, Civil Servants, and Immigrants in the Swedish Welfare State. American Anthropological Association, v.30, n.3, p.199-226, 2002.

GRIFFITHS, M. Vile Liars and Truth Distorters. Truth, Trust and the Asylum System. Anthropology Today, v.28, n.5, p.8-12, 2012.

HARAWAY, D. Situated Knowledges: The Science Question in Feminism and the Privilege of Partial Perspective. Feminist Studies, v.14, n.3, p.575599, 1988.

HARDWIG, J. The Role of Trust in Knowledge. The Journal of Philosophy, v.88, n.12, p.693-708, 1991.

HHC - Hungarian Helsinki Committee. Credibility Assessment in Asylum Procedures. Budapeste: Hulgarian Helsinki Committee, 2013. Disponível em: $\quad$ http://www.helsinki.hu/en/credibility-assessment-in-asylumprocedures-a-multidisciplinary-training-manual/. Acesso em: 18 jun. 2017. HIEBERT, E. J. Political Epistemology and the Subject: Epistemic Injustice as a Primary Mode for Oppression. Res Cogitans, v.6, n.1, p.129-135, 2015.

HOOKWAY, C. Some Varieties of Epistemic Injustice: Reflections on Fricker. Episteme, v.7, n.2, p.151-163, 2010.

HUYSMANS, J. The Jargon of Exception - On Schmitt, Agamben and the Absence of Political Society. International Political Sociology, v.2, n.2, p.165-183, 2008.

. What's an Act? On Security Speech Acts and Little Security Nothings. Security Dialogue, v.42, n.4-5, p.371-383, 2011.

HUYSMANS, J.; NOGUEIRA, J. P. Ten Years of IPS: Fracturing IR. International Political Sociology, v.10, n.4, p.299-319, 2016.

JENSEN, K. The Epistemic Logic of Asylum Screening: (dis)Embodiment and the Production of Asylum Knowledge in Brazil. Ethnic and Racial Studies, v. 41, n.15, p.2615-2633, 2018.

JUBANY, O. Constructing Truths in a Culture of Disbelief: Understanding Asylum Screening from Within. International Sociology, v.26, n.1, p.7494, 2011.

Screening Asylum in a Culture of Disbelief. Truths, Denials and Skeptical Borders. 1.ed. Suíça: Palgrave Macmillan, 2017. 268p. JUBILUT, L. Direito internacional dos refugiados e sua aplicação no ordenamento jurídico brasileiro. 1.ed. São Paulo: Método, 2007. 271p. KAGAN, M. Is Truth in the Eye of the Beholder? Objective Credibility Assessment in Refugee Status Determination. Scholarly Works. Paper 633, 2003. Disponível em: http://scholars.law.unlv.edu/facpub/633/. Acesso em: 25 Jun de 2017.

The Beleaguered Gatekeeper: Protection Challenges Posed by UNHCR Refugee Status Determination. Scholarly Works. Paper 636, 2006. Disponível em: http://scholars.law.unlv.edu/facpub/636/. Acesso em: 25 jun. 2017. 
KALIN, W. Troubled Communication: Cross-Cultural Misunderstandings in the Asylum-Hearing. International Migration Review, v.20, n.2, p.230241, 1986.

KWONG, J. Epistemic Injustice and Open-Mindedness. Hypatia, v.30, n.2, p.337-351, 2015.

LATOUR, B.; WOOLGAR, S. Laboratory Life: The Construction of Scientific Facts. 2.ed. Princeton University Press, 1986. 294p.

LEANDER, A. Ethnographic Contributions to Method Development: "Strong Objectivity" in Security Studies. International Studies Perspectives, v.17, n.4, p.462-475, 2015.

LIPTON, P. The Epistemology of Testimony. Studies in History and Philosophy of Science, v.29, n.1, p.1-31, 1998.

MAGALHÃES, B. Enacting Refugees: An Ethnography of Asylum Decisions. Londres, 2014. 220p. Tese doutoral - Departamento de Política e Relações Internacionais, The Open University.

. The Politics of Credibility: Assembling Decisions on Asylum Applications in Brazil. International Political Sociology, v.10, p.133-149, 2016.

MALKII, L. National Geographic: the Rooting of Peoples and the Territorialization of National Identity among Scholars and Refugees.

Cultural Anthropology, v.7, n.1, p.24-44, 1995.

MARSH, G. Trust, Testimony and Prejudice in the Credibility Economy. Hypatia, v.26, n.2, p.280-293, 2011.

MATON, K. Reflexivity, Relationism, \& Research: Pierre Bourdieu and the Epistemic Conditions of Social Scientific Knowledge. Space and Culture, v.6, n.1, p.52-65, 2003.

MCKINNON, R. Epistemic Injustice. Philosophy Compass, v.11, n.8, p.437-446, 2016.

MEDINA, J. The Relevance of Credibility Excess in a Proportional View of Epistemic Injustice: Differential Epistemic Authority and the Social Imaginary. Social Epistemology, v.25, n.1, p.15-35, 2011.

ORDONEZ, T. The State of Confusion. Reflections on Central American Asylum Seekers in the Bay Area. Ethnography, v.9, n.1, p.35-60, 2008. O'REGAN, V.; RIORDAN, E. Comparing the Representation of Refugees, Asylum Seekers and Migrants in the Irish and UK Press: A corpus-based critical discourse analysis. Journal of Language and Politics, v.17, n.6, p.744-768, 2018.

ORIGGI, O. Is Trust an Epistemological Notion? Episteme, v.1, n.1, p.6172, 2004.

Epistemic Injustice and Epistemic Trust. Social Epistemology, v.26, n.2, p.221-235, 2012.

RIGGS, W. Open-Mindedness. Methaphilosophy, v.41, n.1-2, p.172-188, 2010.

n.2, p.149-162, 2012.

ROUSSEAU, C. et.al. The Complexity of Determining Refugeehood: A Multidisciplinary Analysis of the Decision-Making Process of the Canadian Immigration and Refugee Board. Journal of Refugee Studies, v.15, n.1, p.43-70, 2002. 
SALTSMAN, A. Beyond the Law: Power, Discretion and Bureaucracy in the Management of Asylum Space in Thailand. Journal of Refugee Studies, v.27, n.3, p.457-476, 2014.

SHAPIN, S. A Social History of Truth. Civilian and Science in Seventeenth-Century England. 1.ed. Chicago: The University of Chicago Press, 1994. 512p.

SOGUK, N. States and Strangers: Refugees and Displacements of Statecraft. University of Minnesota Press, 1999. 328p.

SOUTER, J. A Culture of Disbelief or Denial? Oxford Monitor of Forced Migration, v.1, n.1, p.48-59, 2011.

SPIVAK, G. Pode o Subalterno Falar? 2.ed. Belo Horizonte: Editora UFMG, 2014. 174p.

STROM, M.; ALCOCK, E. Floods, Waves, and Surges: the Representation of Latin@ Immigrant Children in the United States Mainstream Media. Critical Discourse Studies, v.14, n.4, p.440-457, 2017.

SWEENEY, J. Credibility, Proof and Refugee Law. International Journal of Refugee Law, v.21, n.4, p.700-726, 2009.

TAYLOR, C. Investigating the representantion of migrants in the UK and Italian press. A cross-linguistic corpus-assisted discourse analysis. International Journal of Corpus Linguistics, v.19, n.3, p.368-400, 2014. TOLEDO DE SOUZA, F. A Crise dos Refugiados e o Refugiado como Crise. Rio de Janeiro, 2016. Tese doutoral - Departamento de Direito, Pontifícia Universidade Católica do Rio de Janeiro (PUC-Rio).

WESTON, A. A Witness of Truth - Credibility Findings in Asylum Appeals. Immigration \& Nationality Law \& Practice, v.12, n.3, p.87-89, 1998. 